\title{
Integrated geochronology and petrogenesis of volcanic suites for tectonic sedimentary studies: Karoo Basin, South Africa
}

Matthew P. McKay

Follow this and additional works at: https://researchrepository.wvu.edu/etd

\section{Recommended Citation}

McKay, Matthew P., "Integrated geochronology and petrogenesis of volcanic suites for tectonic sedimentary studies: Karoo Basin, South Africa" (2015). Graduate Theses, Dissertations, and Problem Reports. 6200.

https://researchrepository.wvu.edu/etd/6200

This Dissertation is protected by copyright and/or related rights. It has been brought to you by the The Research Repository @ WVU with permission from the rights-holder(s). You are free to use this Dissertation in any way that is permitted by the copyright and related rights legislation that applies to your use. For other uses you must obtain permission from the rights-holder(s) directly, unless additional rights are indicated by a Creative Commons license in the record and/ or on the work itself. This Dissertation has been accepted for inclusion in WVU Graduate Theses, Dissertations, and Problem Reports collection by an authorized administrator of The Research Repository @ WVU.

For more information, please contact researchrepository@mail.wvu.edu. 
Integrated geochronology and petrogenesis of volcanic suites for tectonic sedimentary studies: Karoo Basin, South Africa

\author{
Matthew P. McKay \\ Dissertation submitted \\ to the Ebery College of Arts and Sciences \\ at West Virginia University \\ in partial fulfillment of the requirements for the degree of \\ Doctor of Philosophy in the \\ Department of Geology and Geography
}

\author{
Amy Weislogel, Ph.D., Chair \\ Andrea Fildani, Ph.D. \\ Kathleen Benison, Ph.D. \\ Thomas Kammer, Ph.D. \\ Jaime Toro, Ph.D.
}

Department of Geology and Geography

Morgantown, West Virginia

2015

Keywords: U-Pb zircon, geochronology, petrogenesis, Karoo Basin, Gondwana

Copyright 2015 


\title{
ABSTRACT \\ Integrated geochronology and petrogenesis of volcanic suites for tectonic sedimentary studies: Karoo Basin, South Africa
}

\author{
Matthew P. McKay
}

By integrating high-precision, U-Pb zircon geochronology with zircon and whole rock/ tuff geochemistry, the tectonic history of an active margin can be assessed independently from strata preserved in sedimentary basins. This approach is particularly useful in regions where subsequent active tectonism has resulted in extensive igneous intrusion, tectonic dissection, or structural deformation of crustal suites, obscuring the record of previous geologic events. In this work I present $603 \mathrm{U}-\mathrm{Pb}$ zircon age coupled with zircon geochemical analyses collected from Sensitive High Resolution Ion Microprobe (SHRIMP) microanalyses, $15 \mathrm{U}-\mathrm{Pb}$ zircon Thermal Ionization Mass Spectrometry (TIMS) ages, and 109 U-Pb Laser Ablation-Inductively Coupled Plasma Mass Spectrometer (LA-ICPMS), and 41 whole rock geochemical analyses to assess 1) the utility and limitations of $\mathrm{U}-\mathrm{Pb}$ zircon tuff geochronology when estimating absolute depositional ages of strata for chronostratigraphy, 2) the petrogenesis of volcanic tuffs from zircon U-Pb age and rare earth element (REE) compositions, and whole rock major and trace element concentrations, 3) advantages and limitations of geochronologic techniques (TIMS vs. SHRIMP vs. LAICPMS) and 4) the interaction between plate margin magmatism, orogenic deformation, and sedimentation into a tectonically active basin. 


\section{DEDICATION}

This work is dedicated to Katie, the letter " $z$ ", Archibald's BBQ in Northport, AL, and the men and women of the U.S. Coast Guard.

"You've gotta go out, but you don't have to come back."

Semper Paratus 


\section{ACKNOWLEDGMENTS}

Funding for this project was made possible by the SLOPE4 research consortium, American Association of Petroleum Geologists, Society for Sedimentary Geology, West Virginia University, Chesapeake Energy, Geological Society of America, and Dr. Robert Shumaker. Field assistance was provided by R. Brunt, D. Hodgson, S. Flint, A. Fildani, A. Weislogel, J. Dean, C. Findlay, and K. McKay. Special thanks to H. Patel for lab assistance and M. Coble for expert analytical support (SHRIMP). I appreciate the support of my Ph.D. committee and the discussion and feedback provided by my co-authors (A. Fildani, A. Weislogel, R. Brunt, D. Hodgson, S. Flint, A. Hessler, M. Coble, W. Jackson, Jr.). I am grateful for support from my adviser, Dr. Amy Weislogel, and Dr. Andrea Fildani, who were both instrumental in the completion of this project. 


\section{TABLE OF CONTENTS}

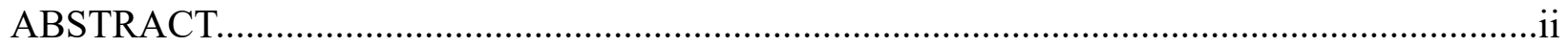

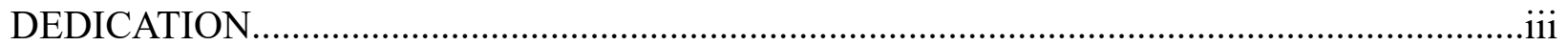

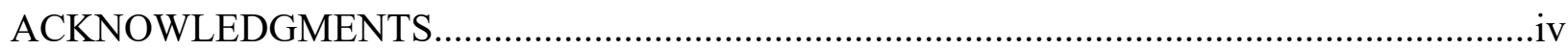

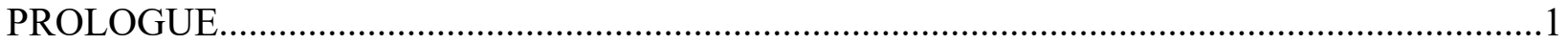

CHAPTER 1: U-Pb ZIRCON TUFF GEOCHRONOLOGY FROM THE KAROO BASIN: IMPLICATIONS OF ZIRCON RECYCLING ON STRATIGRAPHIC AGE CONTROLS

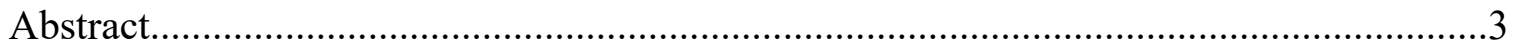

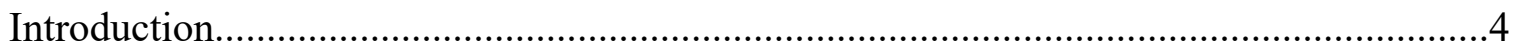

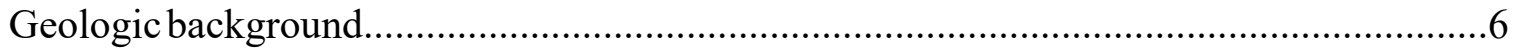

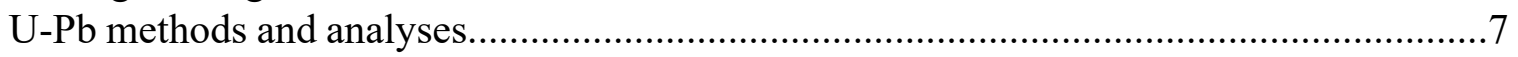

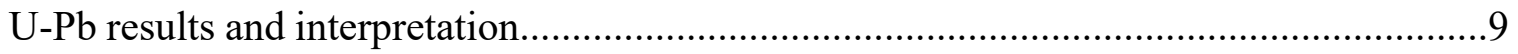

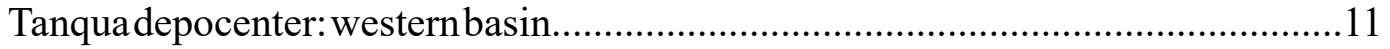

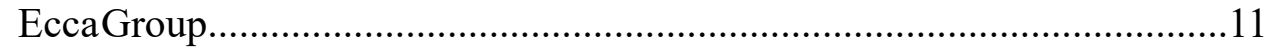

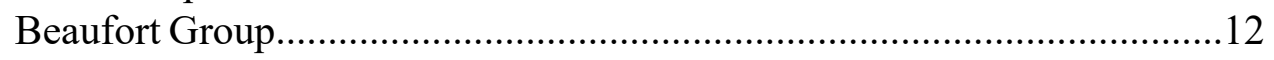

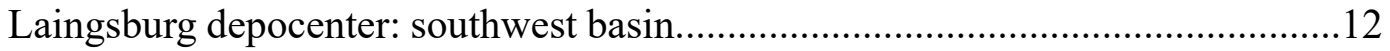

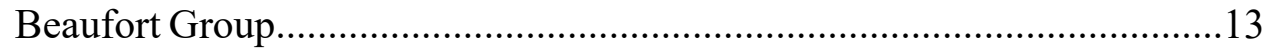

Prince Albert transect: south-central basin..................................................... 14

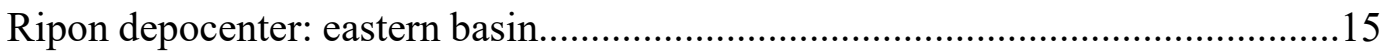

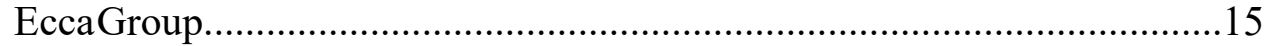

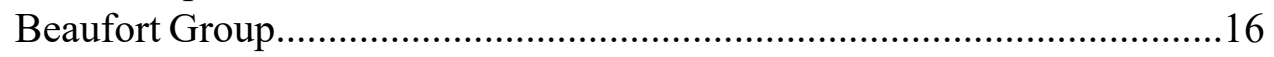

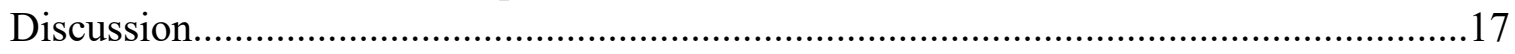

Tuff distribution and composition-Gondwanan tuff gap..................................17

Maximum depositional ages from $\mathrm{U}-\mathrm{Pb}$ zircon analyses................................. 18

Implications for magmatism in southern Gondwana....................................25

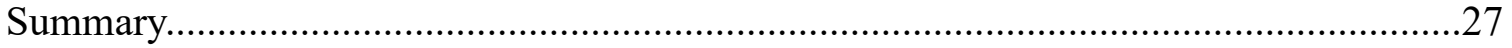

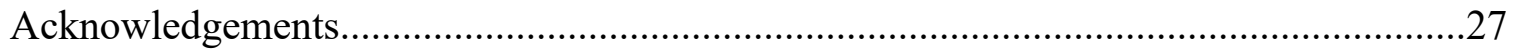

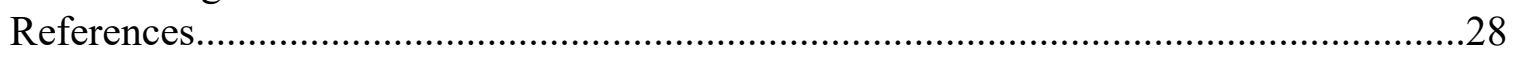

CHAPTER 2: PETROGENESIS AND PROVENANCE OF DISTAL VOLCANIC TUFFS:

A WINDOW INTO A DISSECTED, MAGMATIC PROVINCE

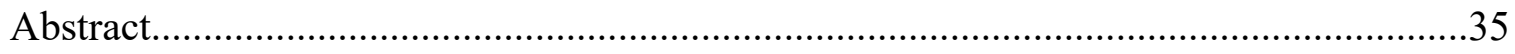

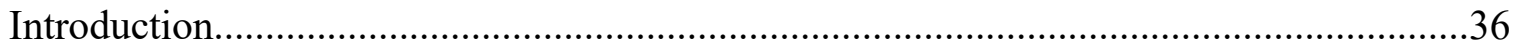

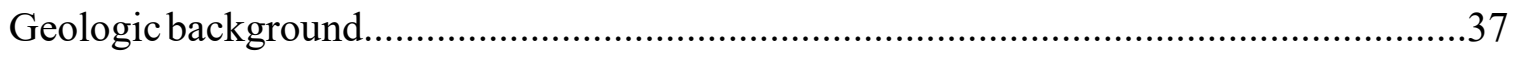

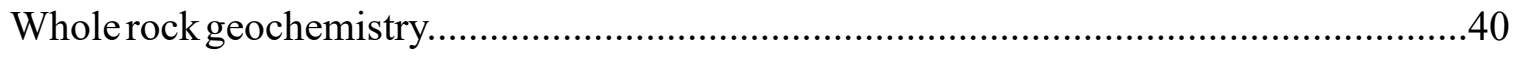

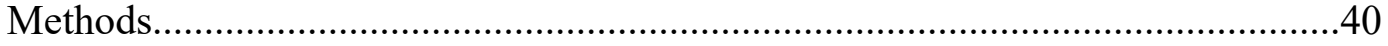

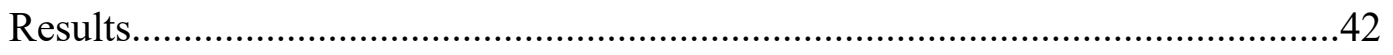

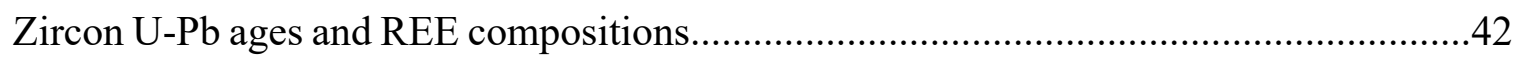

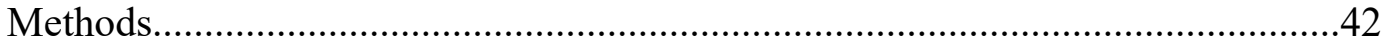

U-Pb zircon maximum depositional ages..........................................................4

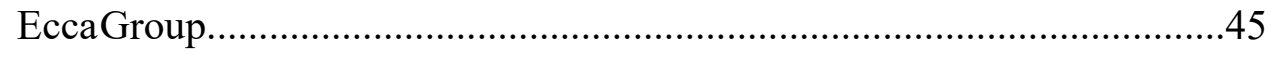

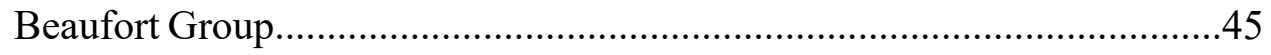




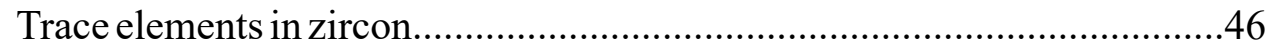

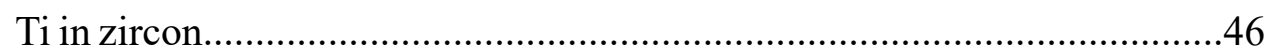

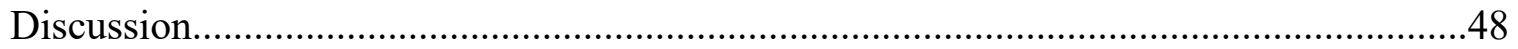

Petrogenesis of Karoo tuffs from whole rock geochemistry...................................48

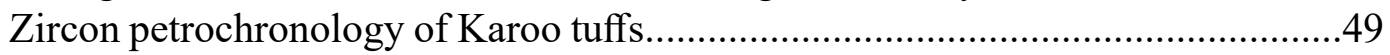

$\mathrm{Zr}$ saturation and inheritance..........................................................................5

Zircon correlation between South Africa and Gondwanan suites.............................51

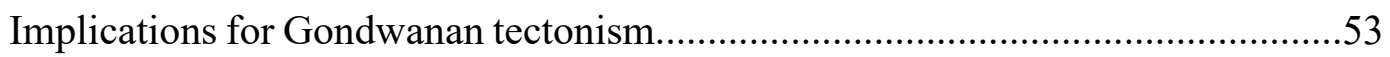

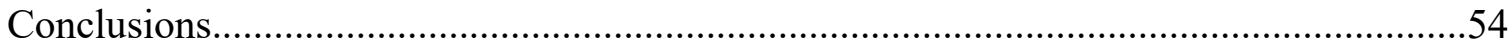

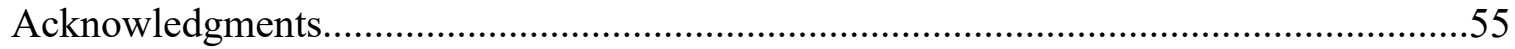

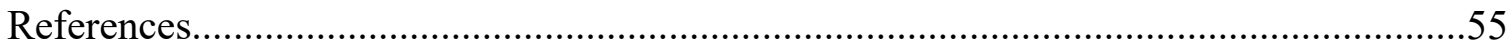

CHAPTER 3: TIMS, LAICPMS, AND SHRIMP PROVIDE DIFFERENT AGES FOR COMPLEX, POLYSTAGE ZIRCON: INHERITANCE OR PB-LOSS?

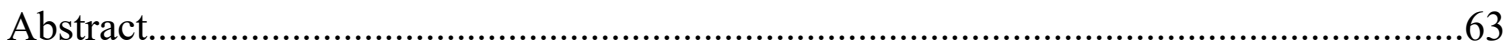

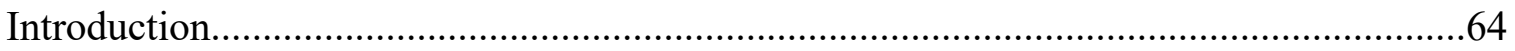

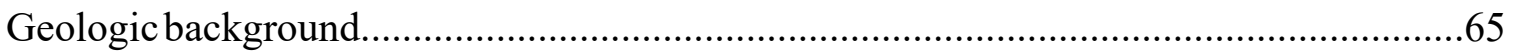

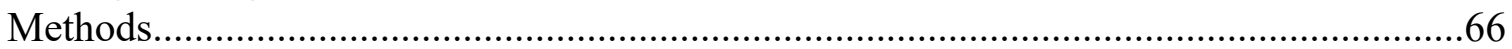

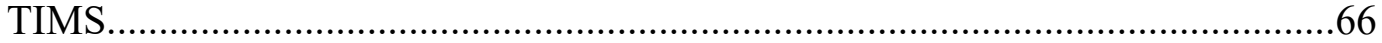

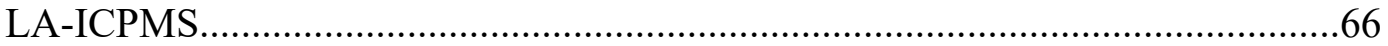

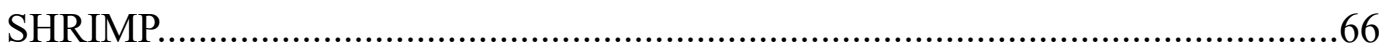

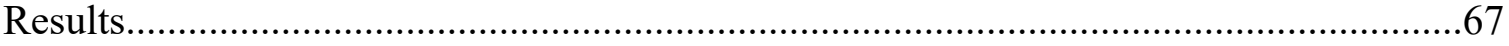

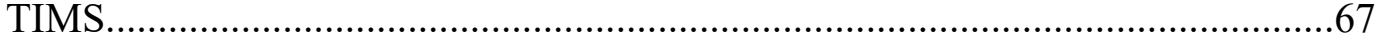

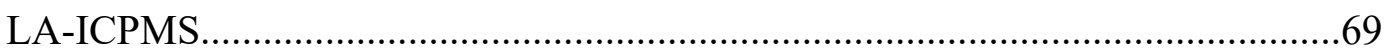

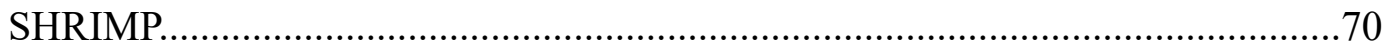

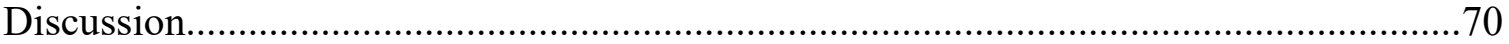

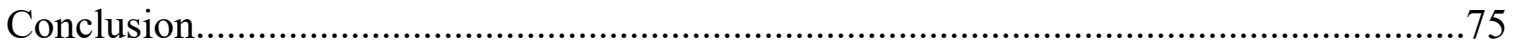

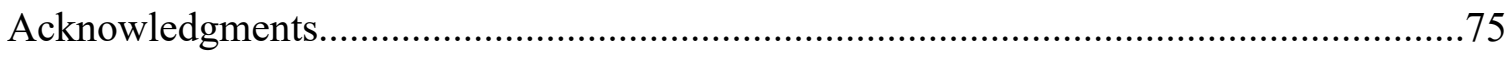

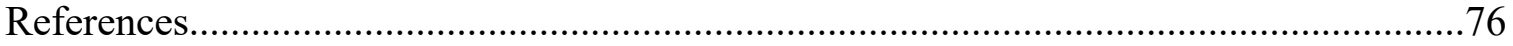

CHAPTER 4: STRUCTURAL AND MAGMATIC CONTROLS ON TURBIDITE SYSTEM DEVELOPMENT: KAROO BASIN, SOUTH AFRICA

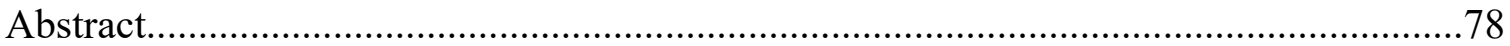

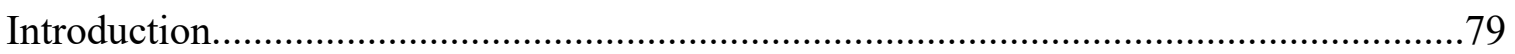

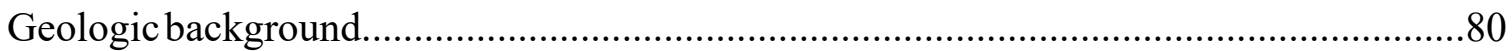

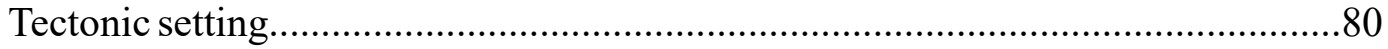

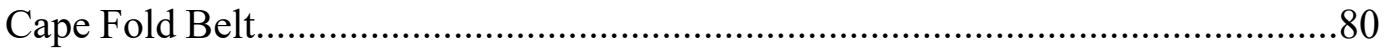

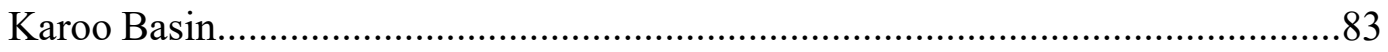

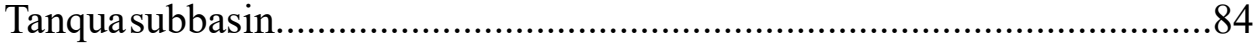

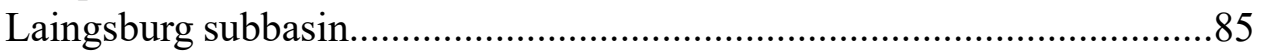

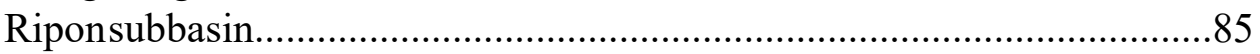

Chronostratigraphic controls from U-Pb zircon ash ages................................................86

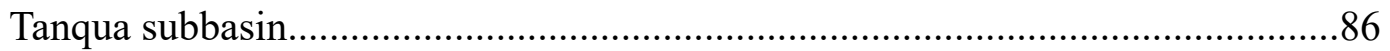

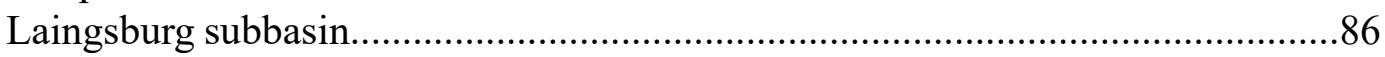

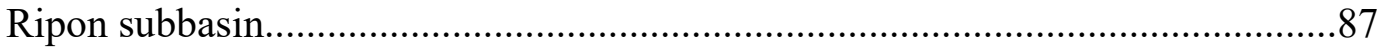


Discussion.

Sediment sources for the Karoo turbidites............................................................89

Deformation and sedimentation.......................................................................

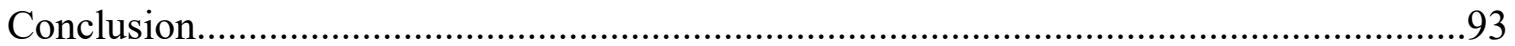

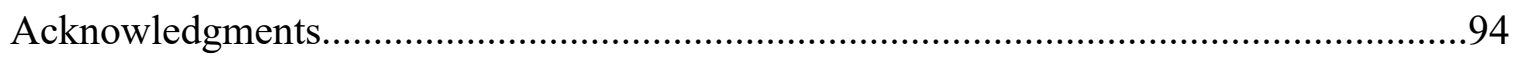

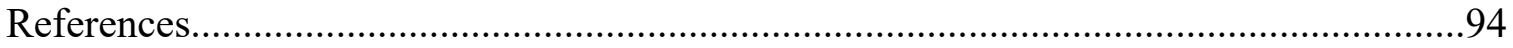

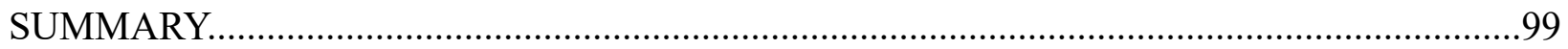

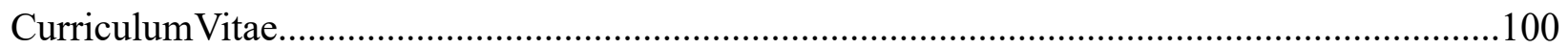

\section{FIGURES}

Chapter 1

Figure 1: Schematic geologic map of S. Gondwana and South Africa.......................5

Figure 2: Example of tuff in the field, CL image and KDE of zircon.........................8

Figure 3: Chronostratigraphy of South Africa and South America..........................10

Figure 4: Maximum depositional ages of Karoo strata............................................13

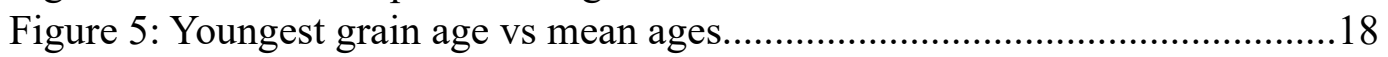

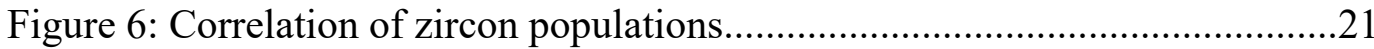

Figure 7: Simplified geologic map of SW. Gondwana and correlation of units....24

Figure 8: Distribution of zircon ages from Antarctica..........................................26

Chapter 2

Figure 1: Simplified geologic map of SW. Gondwana..........................................38

Figure 2: Chronostratigraphic ages of Karoo strata and sample locations..............41

Figure 3: Whole rock geochemistry of Karoo tuffs...............................................43

Figure 4: Zircon REE chemistry.....................................................................4

Figure 5: $\mathrm{Th} / \mathrm{U}$ in zircon from S. America, S. Africa, Antarctica............................52

Figure 6: Map of Gondwana with proposed back arc basin location.......................54

Chapter 3

Figure 1: CL images of zircon selected for TIMS analysis....................................67

Figure 2: Summary of TIMS, LAICPMS, and SHRIMP ages...............................68

Figure 3: TIMS, LAICPMS, and SHRIMP ages from sample 12ZA16................71

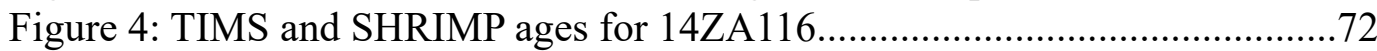

Figure 5: Ti in zircon and WR Zr concentration.................................................

Figure 6: CL images of polygrowth zircon with textural domains \& ages.............75

Chapter 4

Figure 1: Schematic geologic map of S. Gondwana.............................................

Figure 2: Geologic map of South Africa with structural trends..............................81

Figure 3: Photographs of the Karoo turbidites, tuffs, and the Cape Fold Belt.......82

Figure 4: Chronostratigraphic controls for Karoo strata........................................8

Figure 5: Zircon ages from the Karoo Supergroup, CFB, and Karoo tuffs.............87

Figure 6: Schematic chronostratigraphic cross section of the Karoo basin............88 


\section{TABLES}

Chapter 3

Table 1-TIMS U-Pb ages.

Table 2-SHRIMP depth profiled $\mathrm{U}-\mathrm{Pb}$ ages.

\section{APPENDICES}

(also included as electronic supplemental files)

APPENDIX A: UTM sample locations and data summary.

APPENDIX B: Chapter $1 \mathrm{U}-\mathrm{Pb}$ SHRIMP analyses.

APPENDIX C: Chapter 2-Whole rock geochemistry: Part 1: Major Elements.

Part 2: Trace Elements

APPENDIX D: Chapter 2-Zircon U-Pb and REE SHRIMP analyses.

APPENDIX E: Chapter 2-Ti in zircon temperature estimates

APPENDIX F: Chapter 3-U-Pb zircon LAICPMS analyses.

Commonly used symbols and abbreviations

$\begin{array}{ll}\mathrm{Ar} & \text { Argon } \\ \mathrm{Ce} & \text { Cerium } \\ \mathrm{CFB} & \text { Cape Fold Belt } \\ \mathrm{CL} & \text { Cathodoluminescence } \\ \mathrm{HREE} & \text { Heavy rare earth element } \\ \mathrm{KDE} & \text { Kernel density estimate } \\ \mathrm{LA}-\mathrm{ICPMS} & \text { Laser ablation inductively coupled mass spectrometry } \\ \mathrm{LREE} & \text { Light rare earth element } \\ \mathrm{Ma} & \text { Megaanmus (Million years) before present } \\ \mathrm{m} . \mathrm{y} . & \text { Million years (indicating durations) } \\ \mathrm{ppm} & \text { Parts per million } \\ \mathrm{Pb} & \text { Lead } \\ \mathrm{Rb} & \text { Rubidium } \\ \mathrm{REE} & \text { Rare earth element } \\ \mathrm{SHRIMP} & \text { Sensitive high resolution ion microprobe } \\ \mathrm{SIMS} & \text { Secondary ion mass spectrometry } \\ \mathrm{Sr} & \text { Strontium } \\ \mathrm{Ti} & \text { Titanium } \\ \mathrm{TIMS} & \text { Thermal ionization mass spectrometry } \\ \mathrm{Th} & \text { Thorium } \\ \mathrm{U} & \text { Uranium } \\ \mathrm{XRF} & \text { X-ray fluorescence (spectrometry) } \\ \mathrm{Y} & \text { Yttrium } \\ \mathrm{Yb} & \text { Ytterbium } \\ \mathrm{Zr} & \text { Zirconium }\end{array}$




\section{PROLOGUE}

Volcanic tuffs preserved in sedimentary strata are frequently used to provide absolute age controls for the encasing strata, since igneous rocks can be more easily directly dated using radioisotope methods. Tuffs in sedimentary basins may also provide a better record of prolonged magmatism in the deep-time record, since basins are fundamentally dominated by deposition and active igneous provinces are prone to uplift, subsquent magmatic intrusion, deformation, and erosion and may not be preserved. These two motivations have resulted volcanic tuff studies by stratigraphers/ sedimentologists and petrologists, with little integration between the two subdisciplines.

In the following work, I integrate the petrologic and stratigraphic study of volcanic tuffs. In this work tuffs not only provide stratigraphic age controls but also yield insight into the tectonic history of a magmatic system that may no longer be represented in the observable rock record. This study focuses on tuffs preserved in the Karoo Basin of South Africa, that are age correlative to volcanic and igneous rocks throughout late Paleozoic-early Mesozoic Gondwana. In Chapter 1 I address the age of zircon grains in volcanic tuffs and find that the magmatic recycling of zircon can result in older zircon grains in significantly younger $(<20$ m.y.) volcanic tuffs. The trends in zircon ages can be linked along margin magmatic systems through time. In Chapter 2 that concept is advanced by investigating the rare-earth element geochemistry of zircon in volcanic tuffs. The zircon geochemistry supports the findings in Chapter 1, and the magmatic system that sourced the volcanic tuffs in the Karoo Basin may have been sourced from a back-arc system that evolved towards lower $\mathrm{Zr}$ melts in the latest Permian and Early Triassic, which accounts for the lack of Triassic zircon. The data from Chapters $1 \& 2$ was collected using microanalytical techniques, which yield spatial precision such that textural domains with zircon grains can be target at the expense of age precision/uncertainty. In Chapter 3, these results are contrasted with the higher precision Thermal Ionization Mass Spectrometry (TIMS) technique, which analyses the age of entire grains but returns high-precision/low-uncertainty results. Based on the TIMS results and cathodoluminescence images of zircon grains, zircon grains in Karoo volcanic tuffs are polygrowth grains, with multiple phases of zircon growth, and are therefore unsuitable for TIMS age dating. In fact, this chapter highlights the internal age complexity of zircon grains, which was the original motivation for developing microanalytical techniques. Finally, in Chapter 4, I employ the stratigraphic age controls from the previous chapters, and compare/contrast the zircon populations of volcanic tuffs with detrital zircon from clastic units in the Karoo Basin (in part from J. Dean, 2014). The results indicate that turbidite deposition in the Karoo Basin is (a) directly post-dates peak magmatism along the Gondwanan margin, (b) synchronous with uplift of the Cape Fold Belt, and (c) dominated by sediment that is directly sourced from active margin volcanism. Based on these observations, we present a model for sedimentation in the Karoo where high sedimentation rates are controlled by the generation of large volumes of easily erodable volcanic tuffs that was deposited in the Cape Fold Belt and subsequently washed into the basin during initial uplift. This model suggests that increased magmatism may be a factor in turbidite system development.

The integrated techniques in this study were crucial for interpreting not only the age of the sedimentary strata, but also the magmatic history recorded in the Karoo Basin. Therefore, integration of igneous petrology, petrochronology, and radioisotope geochronology should be considered in any stratigraphic study involving volcanic tuffs. 


\section{CHAPTER 1: U-Pb ZIRCON TUFF GEOCHRONOLOGY FROM THE KAROO BASIN, SOUTH AFRICA: IMPLICATIONS OF ZIRCON RECYCLING ON STRATIGRAPHIC AGE CONTROLS}

\section{ABSTRACT}

Along the $>650 \mathrm{~km}$ long southern margin of the Karoo Basin in South Africa, we traversed 4 evenly spaced stratigraphic transects and collected 22 samples of volcanic, air-fall tuffs thought to be distal deposits derived from the Permian-Triassic Southern Gondwanan volcanic arc. We present 469 new U-Pb zircon ages determined by Sensitive High Resolution Ion MicroprobeReverse Geometry (SHRIMP-RG) at the Stanford-USGS Microanalytical Center in order to constrain the maximum depositional ages for the southern Karoo Basin strata. Weighted means of these youngest coherent zircon populations were selected to maximize the number of analyses while minimizing the Mean Square Weighted Deviation (MSWD) to increase the robustness and decrease the influence of $\mathrm{Pb}$-loss and inheritance in determining the maximum depositional age. Maximum depositional ages for the marine Ecca Group range from 250-274 Ma whereas in the conformably overlying terrestrial Beaufort Group maximum depositional ages ranged from 257$452 \mathrm{Ma}$. Across the southern Karoo Basin, the Ecca Group tuffs produce maximum depositional ages that young upward; however, the Beaufort Group tuffs yield maximum depositional ages that are geochronologically out-of-sequence. Furthermore, maximum depositional ages of the Beaufort Group tuffs are consistently older than ash ages within the underlying marine strata. Our results are supported by previously published $\mathrm{U}-\mathrm{Pb}$ tuff zircon geochronology in the Karoo Basin and demonstrate that the presence of out-of-sequence, older tuff ages are repeatable in Beaufort Group tuffs along the southern margin of the basin. We propose that tuff in Karoo Basin are correlative with tuffs in southern South America, and that the age spectra of these tuffs were influenced by magmatic crustal recycling. We use these data to highlight the complexity of $\mathrm{U}-\mathrm{Pb}$ zircon datasets from tuffs, address the use of U-Pb zircon ages to provide absolute age controls, and discuss the implications of these new age controls on the Permian-Triassic Karoo strata.

Keywords: Geochronology; zircon; volcanic tuff; Karoo Basin; Gondwanan volcanism

Submitted in part to the International Geology Review on 26Nov2014; Accepted 13Jan2015:

McKay, M.P., Weislogel, A.L., Fildani, A., Brunt, R.L., Hodgson, D.M., Flint, S.S., (2015), U-Pb zircon tuff geochronology from the Karoo Basin, South Africa: implications of zircon recycling on stratigraphic age controls, International Geology Review, vol. 57 (4), pp. 393-410.

This article can be openly accessed online at www.tandfonline.com 


\section{INTRODUCTION}

The depositional age of clastic sedimentary strata is inherently difficult to date directly, since radiometric ages for clastic detritus reflect the age of the sediment source and not the depositional age of the sediment. Biostratigraphic ages can often be used to obtain relative geologic ages by correlating strata of interest to a Global Stratotype Section and Point (GSSP). GSSP's are defined by fossil assemblage, which precludes the direct correlation of sections between marine and terrestrial sediments. Biostratigraphic correlations, therefore, typically rely on lithostratigraphic classification, although sedimentary deposits are commonly time transgressive. Recent advances in sedimentary geochronology have demonstrated the tenuous nature of biostratigraphy-based ages and have shown that correlating strata to global events is tenuous without absolute age controls (Surpless et al., 2006). One approach for resolving the maximum depositional age of sedimentary strata is through radiometric dating of syneruptive minerals found in volcanic tuffs preserved as interbeds in sedimentary basin fill strata. Zircon U-Pb geochronology is the most frequently employed tool for estimating the eruptive age of a volcanic ash, which is a proxy for the depositional age of the encasing strata (Bowring and Schmitz, 2003). This method requires the assumption that zircon within the ash are co-eruptive, and do not contain 1) older, inherited magmatic grains, 2) detrital zircon from sedimentary reworking and contamination of the ash, and 3) damaged grains that have undergone alteration and $\mathrm{Pb}$-loss. U-Pb zircon data from tuffs do not always demonstrate a well-defined, single population. This suggests that tuffs might contain multiage zircon populations. Therefore, the traditional assumption that zircon grains within tuffs are dominantly co-eruptive is at times flawed. Within the Karoo Supergroup of South Africa, multiple $\mathrm{U}-\mathrm{Pb}$ zircon studies have resolved complex spectra of ages (Coney et al., 2007; Fildani et al., 2007; 2009; Lanci et al., 2013; Rubidge et al., 2013), leading to conflicting age interpretations for the absolute, maximum depositional age of the strata. This problem makes the Karoo strata ideal to test commonly held assumptions that zircon within volcanic tuffs are dominantly co-eruptive and that these ages represent the depositional age of sedimentary strata.

The Karoo Supergroup is in part composed of the marine Ecca Group and the conformably overlying, terrestrial Beaufort Group (Veevers et al., 1994a). The Upper Beaufort Group has long been thought to contain the Permian-Triassic boundary, which was interpreted from biostratigraphic correlations (Smith and Ward, 2001). A paucity of fossils, however, limits biostratigraphic controls

within the Permian-to-Triassic Ecca and Beaufort Groups (Smith, 1995). To circumvent limited biostratigraphic age controls with large uncertainties for the depositional age of the Karoo strata, recent studies have attempted to constrain the absolute age of the vertebrate fossil-defined PermianTriassic boundary within the Karoo Supergroup strata using U-Pb geochronology on zircon from interbedded volcanic tuffs (Coney et al., 2007; Fildani et al., 2007; 2009), similar to the approach 
used to define the age of the GSSP Permian-Triassic boundary from tuffs within fossiliferous marine strata in southern China $(252.28 \pm 0.08 \mathrm{Ma}$; Shen et al., 2011). Fourteen volcanic-ash zircon U-Pb ages from the Beaufort Group in the central and southwestern Karoo Basin have yielded wholly Permian maximum depositional ages ranging from 266-252 Ma (Coney et al., 2007; Rubidge et al., 2013; Lanci et al., 2013). Zircon from 16 tuff samples from the underlying Ecca Group exposed in the southwestern Karoo Basin contain 12 Triassic and 193 Permian grains and yield maximum depositional ages ranging from 275-250 Ma (Fildani et al., 2007; 2009). The presence of latest Permian zircon is also documented in detrital zircon ages from sandstones in the Ecca Group from the southwestern Karoo Basin (Vorster, 2013). Thus, in spite of the geographically and stratigraphically restricted nature of existing tuff zircon $\mathrm{U}-\mathrm{Pb}$ ages, it appears that the radiometric ages from interbedded tuffs in the Upper Ecca Group are younger than tuffs in the overlying Beaufort Group, which is not consistent with the upsection younging trend expected for ash deposits.

To address this apparent contradiction of older $\mathrm{U}-\mathrm{Pb}$ zircon ages in the overlying Beaufort compared to younger ages in the underlying Ecca, we performed a regional study to sample tuffs from both the Ecca and Beaufort Groups across the southern Karoo Basin (Fig. 1). We present 469 new U-Pb zircon single-grain ages to determine maximum depositional ages for 22 air-fall tuffs. Our results include the first age controls for deposition of the Ecca Group in the eastern Karoo

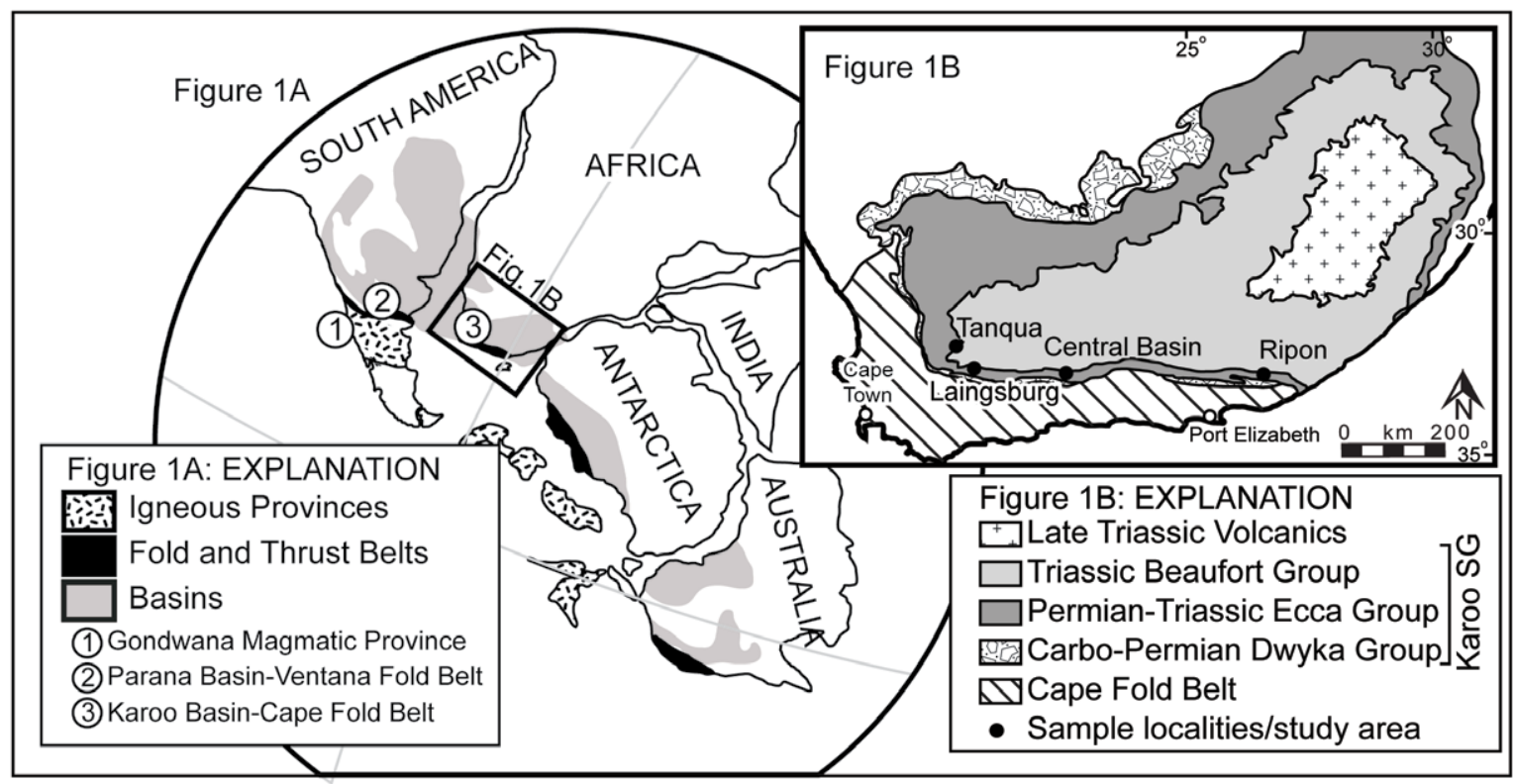

Figure 1: A) Geology of Southern Gondwanan (modified after Zeigler et al., 1983, Lawver et al., 1992; LopezGamundi and Rossello, 1998; Fildani et al., 2007) showing the relative locations of the Gondwanide Magmatic Province, Fold Thrust Belt, and Foreland Basin (i.e. Karoo Basin). B) Geologic map of the Karoo Basin, South Africa (adapted from Catuneanu et al., 2002).Sample localities shown: Tanqua, Laingsburg, Central Basin, and Ripon depocenters. 
Basin along with age controls throughout the entire Ecca Group and lower Beaufort Group for 4 stratigraphic sections spaced across the southern Karoo Basin margin. These results demonstrate that tuffs from the Beaufort Group consistently yield zircon with $\mathrm{U}-\mathrm{Pb}$ ages that overlap or are older than zircon from the tuffs in the underlying Ecca Group. Maximum depositional ages for the Ecca Group range from 274-249 Ma and are coeval across the southern margin of the basin. The maximum depositional ages from the overlying Beaufort Group, however range from 274-255 Ma. In each of the 4 stratigraphic sections, the youngest maximum depositional age of the Beaufort Group tuffs is consistently older than the youngest maximum depositional age of the underlying Ecca Group. This relationship could be satisfied by three interpretations: 1) Ecca Group strata that crop out along the southernmost Karoo Basin are younger than the Beaufort Group strata exposed to the north, which would require a fundamental revision of the regional stratigraphic and/ or structural framework, 2) the volcanic tuffs in the Beaufort Group do not contain syneruptive zircon that reflect the true depositional age, or 3) cryptic Pb-loss has selectively affected zircon in tuffs in the uppermost Ecca Group across the $650 \mathrm{~km}$-long southern margin of the basin, while not affecting zircon in lower Ecca or overlying Beaufort Groups. We consider these competing hypotheses and examine the implications to explore the Permian-Triassic evolution of Southern Gondwana.

\section{GEOLOGIC BACKGROUND}

The Ecca and Beaufort Groups of the late Carboniferous-Jurassic Karoo Supergroup accumulated as a flysch-to-molasse style succession within the Karoo Basin, a tectonically subsiding basin developed in the Gondwanan cratonic interior (Catuneanu et al., 2002; Tankard et al., 2009; Holt et al., 2015). The northeast-southwest elongate basin is bounded by the Cape Fold Belt to the west and south (Fig. 1) that contains three clastic depositional areas: the Tanqua, Laingsburg, and Ripon depocenters. The Karoo Supergroup includes the basal fluvioglacial Dwyka Group (Crowell, 1978), the overlying Ecca Group, and Beaufort Group. Following deposition of the Dwyka Group, deep-water basinal environments shoaled upward into shallow-water, marginal marine environments during deposition of the Ecca Group. The lowermost Ecca Group is mudstone-dominated at the base (Prince Albert, Whitehill, Collingham, Vischkuil, and Tierberg formations) and is overlain by basin-floor, sandy turbidite strata (Skoorsteenberg, Laingsburg, and Ripon formations; Bouma and Wickens, 1994; Catuneanu et al., 2002). The upper Ecca Group consists of submarine slope channel/levee systems (Fort Brown Formation; Hodgson et al. 2011), shelf-edge and shelf clastics (Kookfontein and Waterford formations; Wild et al., 2009; Flint et al., 2011; Jones et al., 2013) that record diachronous filling of the basin (Rubidge et al., 2000). The Beaufort Group records the transition to terrestrial deposystems and evolution of terrestrial vertebrates and macroflora (Groenewald and Kitching, 1995; Smith, 1995; Gastaldo et al., 2005). 
Interbedded throughout the Ecca and Beaufort strata are numerous air-fall volcanic tuffs thought to have been produced by a late Paleozoic Gondwanan magmatic arc, the remnants of which are locally preserved as the Choiyoi and Puesto Viejo magmatic suites in South America (Veevers et al., 1994a; Lopez-Gamundi, 2006; Kleiman and Japas, 2009; Rocha-Campos et al., 2011; LopezGamundi et al., 2013). Choiyoi and Puesto Viejo magmatism dates from 276 to $234 \mathrm{Ma}$ and is responsible for airfall ash deposits in the Paraná (Rocha-Campos et al., 2011) and Cuyo basins (Spalletti et al., 2008) in South America, in addition to the Karoo Basin in South Africa (Fig. 1B), based on paleogeography and geochemistry (Lopez-Gamundi et al., 2006). The Choiyoi and Puesto Viejo magmatic suites, which are separated by a 251-240 Ma tuff gap (Veevers et al., 1994b; Veevers, 2004; Spalletti et al., 2008; Kleiman and Japas, 2009), contain distinct zircon populations. The Permian Choiyoi Group contains an abundant Permian zircon population (Domeier et al., 2011; Rocha-Campos et al., 2011) with some mixing of mid-Permian (>260 Ma) and Late Permian (250-260 Ma) zircon in Late Permian tuffs (Rocha-Campos et al., 2006). The Triassic Puesto Viejo Group is dominated by recycled Permian ( $>260 \mathrm{Ma}$ ) zircon with few co-eruptive zircon (Spalletti et al., 2008; Domeier et al., 2011), interpreted to be due to assimilation of Permian country rocks during Triassic magmatic assent (Domeier et al., 2011). Weighted mean U-Pb ages for the Puesto Viejo Group range from $\sim 260$ Ma to $230 \mathrm{Ma}$ (Spalletti et al., 2008; Domeier et al., 2011; Ottone et al., 2014), even though it is generally accepted that Puesto Viejo magmatism occurred between 241-230 Ma (Kleiman and Japas, 2009; Domeier et al., 2011).

\section{U-PB METHODS AND ANALYSES}

Twenty-two tuffs were sampled from 4 transects through formations of the Ecca and Beaufort Groups exposed along the southern Karoo Basin (Fig. 1; sample locations contained in Appendix A). Five samples were collected from the Tanqua depocenter in the western Karoo Basin and were integrated with previously published results from Fildani et al. $(2007 ; 2009)$ and Lanci et al. (2013). Four new samples were collected from the southernwestern Laingsburg depocenter to augment previously published data in the Laingsburg area (Fildani et al., 2007; 2009). In the eastern Ripon depocenter, ten samples were collected along a single, continuous north-dipping transect. Three samples were collected from the Ecca Group in a mudstone-dominated, condensed section in the central Karoo Basins between the Laingsburg and Ripon depocenters $\left(\sim 22.5^{\circ} \mathrm{E}\right.$; Fig. 1). Zircon grains were separated from tuff (Fig. 2A) samples using mineral separation

techniques, including the use of a Franz magnetic separator to remove high $U$ zircon that may yield discordant results (Sircombe and Stern, 2002). Samples yielded between 0 and $>200$ zircon. Size, morphology, and inclusion density were not considered when selecting zircon for analysis in an effort to characterize the entire zircon population of an ash and not bias results towards prismatic, acicular, euhedral zircon populations. Catholuminescence images (Fig. 2B) were used to target 

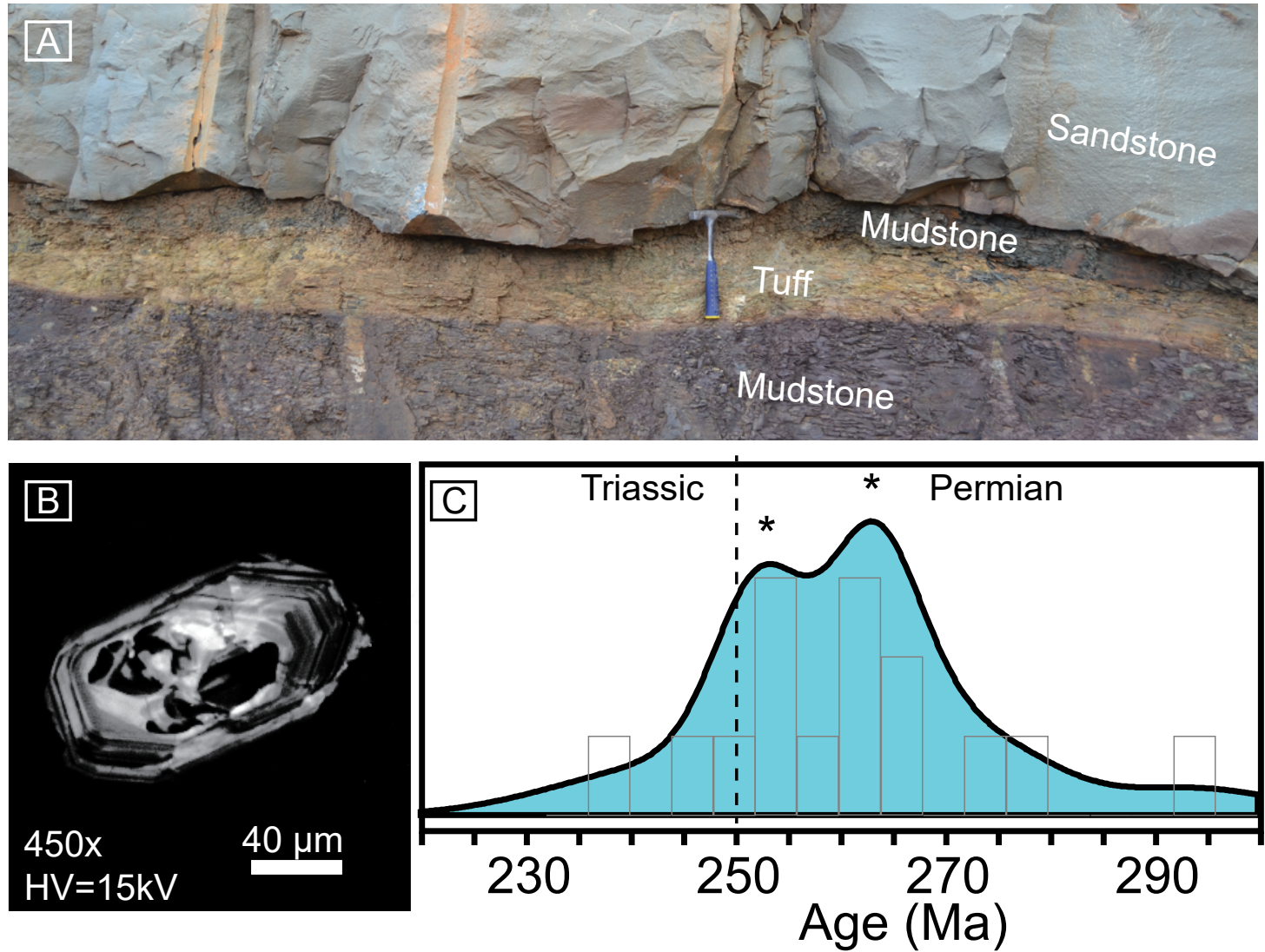

Figure 2: A) Volcanic tuff (hammer for scale) interbedded in mudstones and sandstones in the Karoo Supergroup. B) Catholuminescence image of zircon grain from a tuff in the Ecca Group showing zircon rim and core growths.

C) Kernel density estimate of sample 12ZA07. Peaks between 230-300 Ma are identified with an asterisk.

intermediate $\mathrm{U}$ (100-1000 ppm), oscillatory zoned grain rims and avoid complex cores, when present. Sensitive High Resolution Ion MicroProbe-Reverse Geometry (SHRIMP-RG) analyses of zircon grains were conducted at the Stanford Microscopic Analytical Center under analytical conditions similar to those of Barth and Wooden (2006). SHRIMP-RG results were calculated with reference to the R33 zircon standard (Black et al., 2004) and results were reduced using the SQUID2 software (Ludwig, 2009).

Ages reported are from common- $\mathrm{Pb}$ corrected ${ }^{206} \mathrm{~Pb} /{ }^{238} \mathrm{U}$ ratios. Of the 469 total singlegrain analyses, 353 were accepted on the basis of low common- $\mathrm{Pb}$ concentrations, low uncertainty $(<3 \%)$ and concordance. Grains were determined to be concordant if ${ }^{238} \mathrm{U} /{ }^{206} \mathrm{~Pb}$ and ${ }^{207} \mathrm{~Pb} /{ }^{206} \mathrm{~Pb}$ ages overlapped within uncertainty. Anomalously old zircon $(>300 \mathrm{Ma})$ are interpreted as inherited, xenocrystic or detrital grains, while anomalously young, high-U or high common- $\mathrm{Pb}$ $(<<\sim 250 \mathrm{Ma})$ are dismissed as having been affected by $\mathrm{Pb}$-loss or common-Pb contamination. Kernel density estimate (KDE) plots (Fig. 2C) were used to interpret recycled, inherited zircon from likely autocrystic/co-eruptive zircon populations. Zircon age populations were identified to 
determine tuff maximum depositional ages, which if zircon are syneruptive autocrysts, should equal the eruption age of the tuff. Population ages were then calculated from the weighted average of a coherent zircon population ( $\mathrm{n} \geq 3$ ) using Isoplot 3.75 (Ludwig, 2008). Although calculating maximum depositional ages from coherent age populations commonly produces higher uncertainty compared with using the youngest single-grain age from a sample, it is viewed as a more robust age given the greater reproducibility. A table of analytical results is provided in Appendix B. Maximum depositional age interpretations are reported in their sampled stratigraphic locations with numerical age interpretations (Fig. 3) and schematically with associated errors (Fig. 4) to demonstrate stratigraphic trends in tuff ages.

\section{U-PB RESULTS AND INTERPRETATION}

Analysis of 22 ash samples from the marine Ecca and terrestrial Beaufort groups of the lower Karoo Supergroup yielded 116 pre-Permian, 223 Permian, and 14 Triassic concordant zircon ages of 469 total analyses. In many samples, zircon produced a dispersed range of ages ( $>20 \mathrm{Ma})$. While this age range could be due to mixing of different age domains within individual zircon grains during analysis, analytical uncertainty, or Pb-loss (Castiñeiras et al., 2010), magma system evolution is complex and commonly recycles older zircon into later eruption/emplacement events and some individual plutons have been resolved to be emplaced over a period of $>10 \mathrm{Ma}$ (Coleman et al., 2004; Miller et al., 2007; Schwartz et al., in press). The suspected volcanic sources, the Choiyoi and Puesto Viejo igneous suites, are known to have large populations of recycled zircon (Spalletti et al., 2008; Domeier et al., 2011; Ottone et al., 2014). We therefore interpret this range to represent mixing of zircon age population based on A) high mean square weighted deviation (MSWD) (1.6-17) of the weighted mean for Permian/Permo-Triassic zircon populations (Miller et al., 2007; Compston \& Gallagher, 2012), B) lack of inherited cores interpreted from cathodoluminescene images, C) the reproducibility of ages between several grains $(n>=3), D)$ concordance of the analyses, and E) known history of the volcanic system. In order to avoid introducing bias towards inherited/ recycled zircon age populations, maximum depositional ages are calculated from the weighted mean of the youngest, concordant zircon population $\left(\mathrm{P}_{1}\right)$ of three or more analyses as identified by kernel density plots, to minimize the risk of producing an age affected by $\mathrm{Pb}$-loss (Dickinson and Gehrels, 2008). Inherited zircon population ages $\left(\mathrm{P}_{2}\right)$ were interpreted using the same approach on older, concordant zircon populations. This approach decreases the total number of analyses, which could negatively affect the uncertainty in the weighted mean age. The result, however, more likely represents the eruption age of the ash and in most cases produces higher precision ages and a lower MSWD. This approach differs from the method used by Lanci et al. (2013) where interpreted ash ages were calculated from all zircons between $300 \mathrm{Ma}$ and $250 \mathrm{Ma}$ and included all ages within a dispersed range of up to $20 \mathrm{~m}$.y. Results from previous geochronology studies on tuffs within 

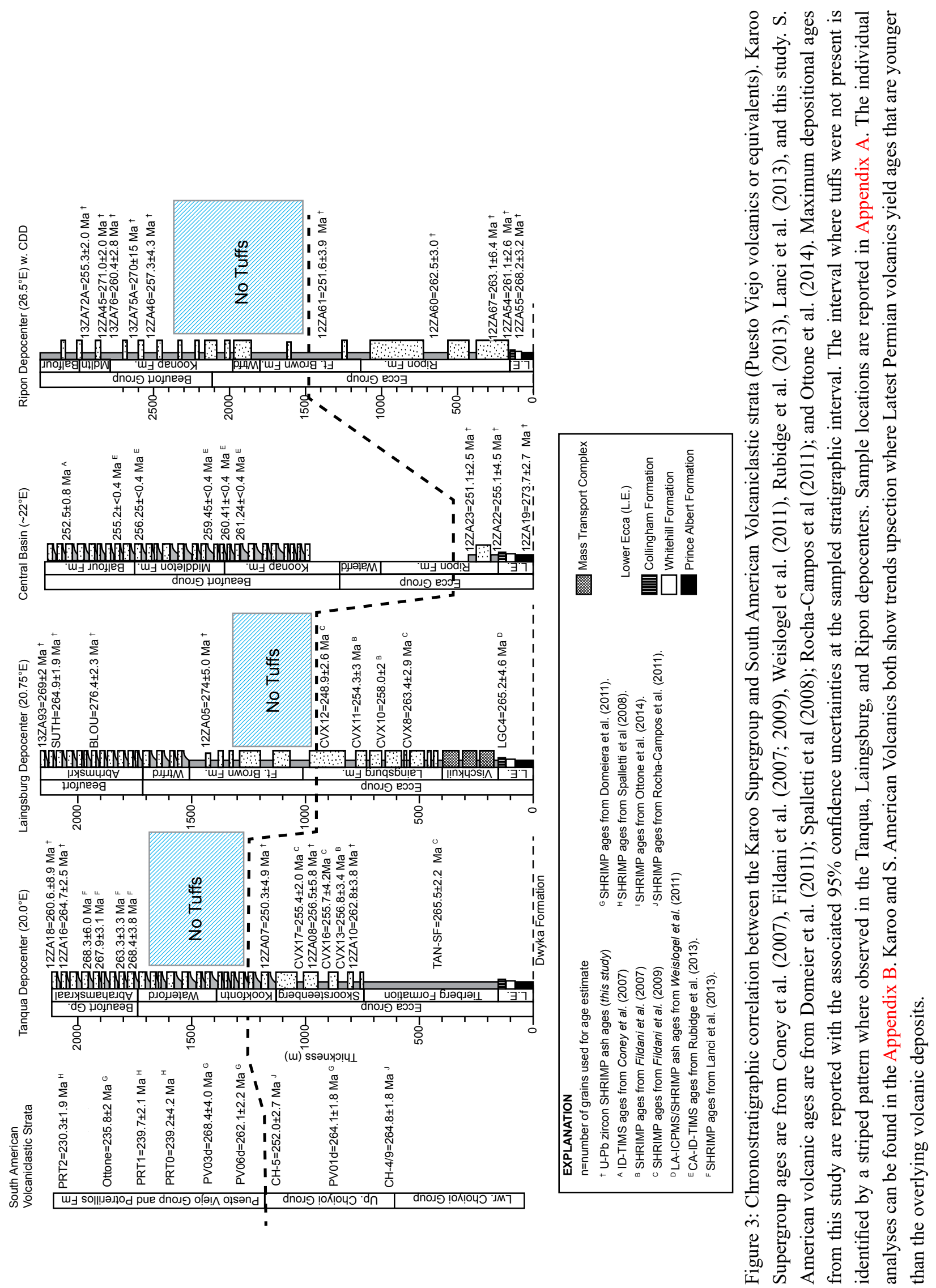
the Karoo Supergroup (Coney et al., 2007; Fildani et al., 2007; 2009; Lanci et al., 2013, Rubidge et al., 2013), tuffs within correlative basins (Spalletti et al., 2008; Domeier et al., 2011; RochaCampos et al., 2006; 2013; Lopez-Gamundi et al. 2011;) and Permo-Triassic crustal plutonic rocks (Pankhurst et al., 2014) in South America contained populations of inherited grains. Based on this known inheritance, indiscriminately including these older zircons in weighted age calculations is not a favorable approach to obtain reasonable maximum depositional ages for the Karoo tuffs. Therefore, our ages are presented as weighted averages of the youngest zircon population to avoid introducing statistical bias towards dominant inherited populations when determining tuff ages. These results are shown in stratigraphic order, with uncertainties reported at a $95 \%$ confidence level (Fig. 3). Also provided are previously reported ages for the Karoo strata and reported ages of comparable South American volcanic suites.

\section{Tanqua Depocenter}

Ecca Group. Three tuffs were sampled from the Ecca Group to augment the existing 5 tuff ages from Fildani et al. (2007; 2009) (Location on Fig 1B). Results from samples collected from the Tanqua depocenter are described in ascending stratigraphic order. While tuffs are common throughout the section and the samples presented here represent only a small fraction of the tuffs in the Karoo strata, no volcanic deposits were found in the interval between sample 12ZA07 in the Ecca Group and 12ZA16 in the Beaufort Group.

Sample 12ZA10. The lowermost sample in the Tanqua depocenter is 12ZA10, which was collected from a $\sim 3 \mathrm{~cm}$ thick, green, clay-textured tuff interbedded with mudstones in lower Skoorsteenberg Formation of the Ecca Group. Of 13 total analyses, 4 were rejected based on high discordance. Nine individual zircon analyses yielded concordant U-Pb ages that range from 275$255 \mathrm{Ma}$. The youngest population consists of 4 grains that range from 264-255 Ma and yield a weighted average of $262.8 \pm 3.8 \mathrm{Ma}(\mathrm{MSWD}=0.49)$; the older population consists of 5 grains that range from 275-268 Ma and that yield a weighted average of 271.6 $\pm 3.0(\mathrm{MSWD}=0.40)$.

Sample 12ZA08. Sample 12ZA08 was collected 175 meters upsection from 12ZA10, from a $\sim 1 \mathrm{~cm}$ thick, light green, clay-textured tuff interbedded in mudstones in the middle Skoorsteenberg Formation of the Ecca Group. Of 16 total analyses, 10 analyses yielded concordant ages. Carboniferous ages $(309,311 \mathrm{Ma})$ were produced from two discordant analyses, while the youngest ages are concordant and Permian-Triassic in age (270-252 Ma). The youngest population consists of 5 grains that range from 265-253 Ma and yield a weighted averages of 256.5 $\pm 5.8 \mathrm{Ma}$ $(\mathrm{MSWD}=1.3$ ). An older population of 5 grains ranges from 270-267 Ma and produces a weighted average of $267.8 \pm 2.6(\mathrm{MSWD}=0.22)$. 
Sample 12ZA07. Sample 12ZA07 is from a $5 \mathrm{~cm}$ thick, tan-to-green/grey tuff interbedded in mudstones near the base of the Kookfontein Formation of the Ecca Group, which conformably overlies the Skoorsteenberg Formation. Sample 12ZA07 is approximately 225 meters stratigraphically above sample 12ZA08. Of the 18 zircon analyzed, 5 were rejected due to discordance. From the 13 concordant ages, 2 anomalously old ages (539 and $294 \mathrm{Ma}$ ) are dismissed as inherited outliers, while 11 Permo-Triassic grains range from 273-237 Ma. The youngest 5 grains form a coherent population ranges from 254-237 Ma that produces a weighted average of $250.3 \pm 4.8 \mathrm{Ma}(\mathrm{MSWD}=1.0)$. An older population of 6 grains ranges from 273-259 Ma and yields a weighted average of $267.8 \pm 5.9(\mathrm{MSWD}=2.9)$.

Beaufort Group. Two tuffs were sampled from the Adelaide Subgroup of the Beaufort Group to augment 4 tuff ages from Lanci et al. (2013).

Sample 12ZA16. Sample 12ZA16 is from a 5-10 cm thick, white, chalky tuff interbedded within mudstones in the lower Abrahamskraal Formation (Adelaide Subgroup) of the Beaufort Group. Of the 16 total analyses, 11 yielded concordant ages ranging from 291-256 Ma. One analysis yielded an age of $291 \mathrm{Ma}$ and is considered to be an outlier, since it is $17 \mathrm{~m}$.y. older than the next youngest age. The youngest coherent population of zircon yields a weighted average of $264.7 \pm 2.5 \mathrm{Ma}(\mathrm{MSWD}=0.86)$ from 7 grains, with an older $>270 \mathrm{Ma}$ population of 3 grains that yields a weighted average of $271.8 \pm 2.4 \mathrm{Ma}(\mathrm{MSWD}=0.25)$.

Sample 12ZA18. Sample 12ZA18 is from a $45 \mathrm{~cm}$ thick, white-to-green tuff in the upper Abrahamskraal Formation (Adelaide Subgroup) of the Beaufort Group, approximately 50 meters above 12ZA16. From 37 total analyses, 28 concordant ages were produced. Inherited, pre-Permian grains dominate the sample, with 17 concordant analyses ranging from 2607-359 Ma. Permian age grains range from 290-238 Ma. The two oldest Permian grains (286, $290 \mathrm{Ma}$ ) are dismissed as inherited outliers. The youngest populations of 4 grains ranges from 267-255, which yields a weighted average of 260.6 \pm 8.9 (MSWD=7.4). An older population of 5 grains ranges from 278$272 \mathrm{Ma}$ and produces a weighted average of 274.5 $\pm 3.9(\mathrm{MSWD}=1.4)$. Two older, Permian grains (286, $290 \mathrm{Ma})$ may represent a minor population, but are considered as significantly older, inherited outliers. Two Triassic ages $(238,239 \mathrm{Ma})$ form a small population, but both analyses have elevated common $\mathrm{Pb}$ values.

\section{Laingsburg Depocenter; Southwest Basin}

Because the Ecca Group tuffs were well characterized by Fildani et al. (2007; 2009), we sampled tuffs in the Adelaide Subgroup of the Beaufort Group from the Laingsburg subbasin (Fig 1B) and report 4 new tuff ages. Like the Tanqua section, tuffs are common thoughout the strata, 
however, no tuffs were identified between the samples presented by Fildani et al. (2007; 2009) and 12ZA05.

Sample 12ZA05. Sample 12ZA05 was collected from a $\sim 30 \mathrm{~cm}$ thick, well-lithified, lightbrown tuff within the upper Fort Brown Formation of the Ecca Group in the Laingsburg subbasin. Out of 18 total analyses, 14 grains produced concordant ages. Older, $>300$ Ma grains dominate this sample, since 13 of 14 concordant ages ranged from between 2139-304 Ma. Only 1 analysis yielded a concordant Permian age of $274.3 \pm 4.6 \mathrm{Ma}$.

Sample BLOU. Sample BLOU was collected from a well-lithified tuff interbedded in the Abrahamskraal Formation (Adelaide Subgroup) of the Beaufort Group. Of 26 total analyses, 22 grains produced concordant $\mathrm{U}-\mathrm{Pb}$ ages. The tuff was dominated by older, $>300 \mathrm{Ma}$ grains, with 14 grains between $\sim 3.2 \mathrm{Ga}$ and $372 \mathrm{Ma}$. Of 8 Permian grains ranging from 289-272 Ma, 6 grains were
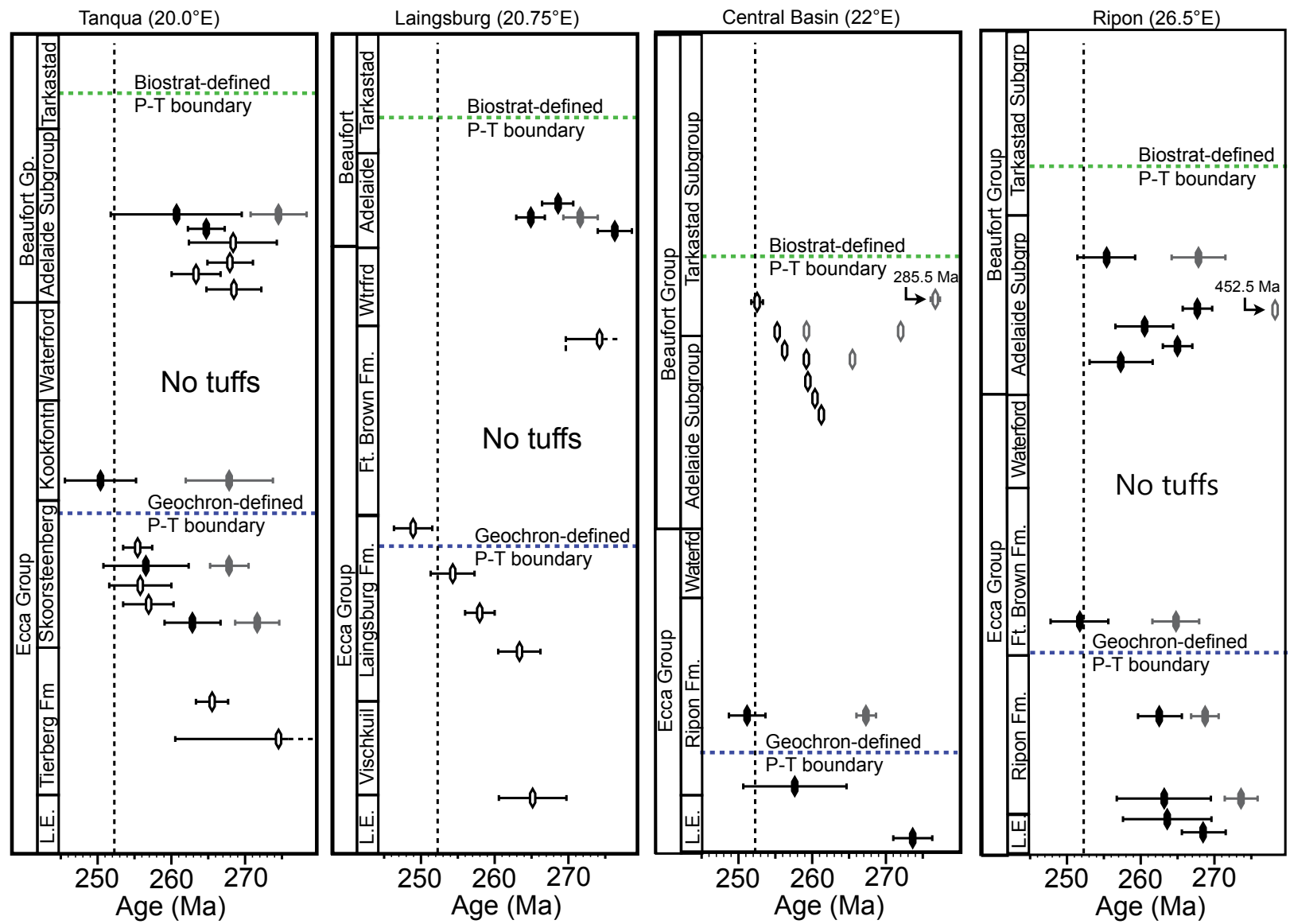

\section{EXPLANATION}

U-Pb zircon SHRIMP ash ages (this study)

Ash age estimate $\left(P_{1}\right) \pm$ uncertainty

Inherited age population $\left(\mathrm{P}_{2}\right) \pm$ uncertainty

$\longmapsto$ Previously reported ash age \pm uncertainty

$\longmapsto$ Previously reported inherited age \pm uncertainty
Figure 4: Maximum deposition ages, based on $\mathrm{U}-\mathrm{Pb}$ zircon, from Figure 3, shown schematically, with associated error. In all four studied sections, maximum depositional ages young upsection in the Lower and Middle Ecca. Proceeding upsection, an interval is encountered with few to no tuffs. Above this tuff-free interval, $\mathrm{U}-\mathrm{Pb}$ zircon based maximum depositional ages are chaotic and older than in the underlying strata. 
interpreted to form a coherent population ranging between 279-272 Ma that produced a weighted mean of $276.4 \pm 2.3(\mathrm{MSWD}=0.69)$.

Sample SUTH. Sample SUTH was collected from a well-lithified tuff interbedded in the Abrahamskraal Formation (Adelaide Subgroup) of the Beaufort Group. Of 32 total analyses, 22 grains produced concordant ages. An older group of 8 concordant ages ranged between 1750-468 Ma, while 14 concordant Carboniferous-Permian ages ranged from 301-260 Ma. Two populations are interpreted from Permian ages. The youngest coherent population of 6 ages that range from 267-260 Ma and yields a weighted mean of 264.9 $\pm 1.9 \mathrm{Ma}$ (MSWD=1.17); an older, coherent population of 4 grains range from 276-270 Ma and yields a weighted mean age of $271.7 \pm 2.3 \mathrm{Ma}$ $(\mathrm{MSWD}=1.17)$.

Sample 13ZA93. Sample 13ZA93 was collected from a $\sim 25 \mathrm{~cm}$ thick tuff interbedded between mudstones in the upper Abrahamskraal Formation (Adelaide Subgroup) of the Beaufort Group. Only 8 zircon grains were separated and $\mathrm{U}-\mathrm{Pb}$ analysis reveals that the zircon grains are largely recycling, since 6 of 8 are $>300$ Ma. No coherent zircon population was interpreted from the two Permian grains (269, $280 \mathrm{Ma})$ present and the youngest grain, $269 \mathrm{Ma}$ is reported on Fig. 4.

\section{Prince Albert Transect; South-central basin}

Three samples were collected from the lower Ecca Group in the central basin (Fig 1B), near Prince Albert, Western Cape. This location is located between the Laingsburg and Ripon subbasins. The strata here represent a condensed section, and no tuff gap is reported for this composite section, however this region has not been fully logged or studied in detail. These data augment work by Rubidge et al. (2013), who reported ID-TIMS zircon U-Pb ages from tuffs within the Adelaide and Tarkastad Subgroups of the Beaufort Group 100 kilometers to the north.

Sample 12ZA19. Sample 12ZA19 was collected from a light-green ash approximately $8 \mathrm{~m}$ above the base of the Prince Albert Formation of the Ecca Group. Of 19 zircon that were analyzed, 11 concordant ages were produced. Concordant, inherited zircon ages were 526, 542, $642 \mathrm{Ma}$, while 8 Permian, concordant zircon ages range from 281-272 Ma. Two populations of zircon are interpreted from concordant ages with the youngest population of 6 grains that range from 277-272 Ma and yield a weighted average of $273.7 \pm 2.7 \mathrm{Ma}(\mathrm{MSWD}=0.37)$, with 2 older $\sim 280 \mathrm{Ma}$ grains $(280,281 \mathrm{Ma})$ treated as outliers.

Sample 12ZA22. Sample 12ZA22 was collected from a brown, fissile ash near the base of the Ripon Formation of the Ecca Group. This ash yielded zircon that produced 13 concordant ages from 18 total analyses. Concordant, inherited zircon ages ranged from 432-1018 Ma (n=7), while 6 Permian-Triassic, concordant zircon ages range from 266-248 Ma. Two population of zircon are 
interpreted from concordant ages; the youngest population of 4 grains ranges from 259-248 Ma and yields a weighted average of $255.1 \pm 4.5(\mathrm{MSWD}=0.76)$ Ma. An older $\sim 265 \mathrm{Ma}$ population is represented by 2 grains $(266,264 \mathrm{Ma})$ that are treated as outliers.

Sample 12ZA23. Sample 12ZA23 was collected from a soft, green, clay-rich ash in the Ripon Formation of the Ecca Group. Of 34 grains analyzed, 30 analyses yielded concordant, Permian-Triassic ages that range from 249-283 Ma. A single, concordant $470 \mathrm{Ma}$ age was also produced. Based on a histogram of concordant Permo-Triassic ages, age spectra peaks occur at $\sim 282 \mathrm{Ma}, \sim 271 \mathrm{Ma}, \sim 266 \mathrm{Ma}, 258 \mathrm{Ma}$, and $250 \mathrm{Ma}$. A population of 7 zircon have concordant age ranges from 249-257 Ma and yields a weighted average of 251.1 $\pm 2.5 \mathrm{Ma}(\mathrm{MSWD}=1.07)$. Grouping of the 20 older, Permian analyses results in a weighted average of $267.3 \pm 1.3$ (MSWD=0.91).

\section{Ripon Depocenter; Eastern Basin}

Nine samples were collected from the Ripon Depocenter in the eastern Karoo Basin; 4 from the Ecca Group and 5 from the Adelaide Subgroup of the Beaufort Group. All 9 samples are from a single continuous, north-dipping section exposed in road-side outcrops and represent the first geochronology in the eastern basin (Fig 1B). No volcanic deposits were found in the interval between sample 12ZA61 in the upper Ecca Group and 12ZA46 in the lower Beaufort Group. The rest of the strata contained numerous tuff beds interbedded throughout the strata.

Sample 12ZA54. Sample 12ZA54 was collected from a brown, clay-rich ash about 1.5 meter below the top of the Collingham Formation of the Ecca Group. Of 16 total zircon analyses, 10 grains yielded concordant ages. The oldest ages $(458,456,431 \mathrm{Ma})$ were produced from concordant analyses, while the youngest, concordant, Permian-Triassic ages range from 277-257 $\mathrm{Ma}$ ). A coherent population of 5 zircon ranges from 269-257 Ma and produces a weighted average of 263.1 $\pm 6.4 \mathrm{Ma}(\mathrm{MSWD}=1.4)$. Two inherited Permian grains of 271 and $277 \mathrm{Ma}$ are treated as outliers.

Sample 12ZA55. Sample 12ZA55 was collected from a green, clay-rich ash approximately $6 \mathrm{~m}$ above the base of the Collingham Formation. From 18 total zircon analyses, 9 grains produced concordant ages. A single inherited zircon produced a concordant age of $341 \mathrm{Ma}$, while 8 grains produced concordant, Permian ages that range from 291-259 Ma. One population of zircon is interpreted from 6 concordant ages that range from 269-259 Ma and yield a weighted average of 268.0 $\pm 3.2 \mathrm{Ma}(\mathrm{MSWD}=1.4)$.

Sample 12ZA60. Sample 12ZA60 was collected from a clay-rich, white-to-tan ash within the Ripon Formation of the Ecca Group. Of 16 total zircon analyses, 14 concordant ages were produced. The oldest ages $(450,351 \mathrm{Ma})$ were produced from concordant analyses, while the 
younger, concordant, Permian ages $(n=12)$ range in age from 295-257 Ma. Two populations of zircon are interpreted from concordant ages; the youngest population of 5 grains ranges from 264$257 \mathrm{Ma}$ and yields a weighted average of $262.5 \pm 3.0 \mathrm{Ma}(\mathrm{MSWD}=0.21)$, while an older population of 6 grains yields a weighted average age of $268.7 \pm 1.8(\mathrm{MSWD}=0.92)$.

Sample 12ZA61. Sample 12ZA61 was collected within a clay-rich ash within the Lower Fort Brown Formation of the Ecca Group. Of 25 total analyses, 21 zircon grains produced concordant ages. Older, inherited ages (516, 520, $1108 \mathrm{Ma})$ were produced from concordant analyses, while younger, Permian-Triassic, concordant ages range in age from 274-232 Ma. A significant late Permian to middle Triassic population was resolved in this sample, however three of the analyses have high uncertainties, making them less reliable than high-precision analyses, but still meaningful. Two populations of zircon are interpreted from concordant ages; the youngest population of 8 grains ranges from 257-232 Ma and yields a weighted averages of 251.6 $\pm 3.9 \mathrm{Ma}$ $(\mathrm{MSWD}=2.8)$, while an older population of 10 grains ranges from 274-257 produced a weighted average of $264.7 \pm 3.2(\mathrm{MSWD}=1.9)$.

Sample 12ZA46. Sample 12ZA46 was collected from an ash within the Koonap Formation (Adelaide Subgroup) of the Beaufort Group. Only 11 zircon grains were recovered from this sample. All 11 grains were analyzed, however only 9 produced concordant ages. Older, inherited ages $(325,464,478,523 \mathrm{Ma})$ were produced from concordant analyses, while younger, Permian concordant ages range from 285-253 Ma, excluding a concordant 229 Ma analysis with high common- $\mathrm{Pb}$. One population of zircon is interpreted from concordant ages that range from 260$253 \mathrm{Ma}$ and yields a weighted average of $257.3 \pm 4.3 \mathrm{Ma}(\mathrm{n}=4)$, with a single $285 \mathrm{Ma}$ grain treated as a statistical outlier.

Sample 13ZA75A. Sample 13ZA75 was collected from a brown, gritty ash within the Koonap Formation (Adelaide Subgroup) of the Beaufort Group. Of 15 total analyses, only 8 grains yielded concordant ages. Older, inherited ages $(431,469,505,584,1112 \mathrm{Ma})$ were produced from concordant analyses, while 3 younger, concordant Permian ages are scattered at 265, 270, 278 Ma. No distinct zircon population is interpreted from this sample, and a weighted mean age of the 3 Permian zircon is $270 \pm 15$ Ma.

Sample 13ZA76. Sample 13ZA76 was collected from a white, chalky ash within the upper Koonap Formation. Of 40 total analyses, 31 grains produced concordant ages. Inherited, prePermian grains range from 1721-326 Ma $(n=6)$. Two populations are interpreted from Permian ages, with the youngest population of 8 grains producing an age of $260.4 \pm 2.8(\mathrm{MSWD}=1.9)$, while a $267.6 \pm 1.5(\mathrm{MSWD}=0.84)$ is interpreted as an inherited population. 
Sample 12ZA45. Sample 12ZA45 was collected from an ash interbedded in a mudstonerich interval of the uppermost Koonap Formation of the Beaufort Group. Only 9 zircon grains were recovered from this sample. All 9 grains were analyses; 6 grains produced concordant ages Additional analysis was hampered due to a low abundance of zircon in this sample. Older, inherited concordant ages $(445,454,455,457 \mathrm{Ma}, 522,1098)$ dominate the zircon population, with the only younger age $(271 \mathrm{Ma})$ excluded due to high discordance. The 4 Ordovician zircon form a tight cluster, and yield a 452.5 $\pm 9.5 \mathrm{Ma}(\mathrm{MSWD}=2.7)$ weighted average age.

Sample 13ZA72A. Sample 13ZA72 was collected from a white, chalky-textured ash within the Middleton Formation (Adelaide Subgroup) of the Beaufort Group. Of 32 total analyses, 28 grains produced concordant ages. Concordant, pre-Permian ages $(n=11)$ range from 1102-334 Ma, and concordant Permian zircon range between 282-252 Ma ( $\mathrm{n}=17)$. Two coherent populations are interpreted; the youngest population of 4 grains ranges from 258-252 Ma produces a weighted mean age of $255.3 \pm 4.0(\mathrm{MSWD}=1.3$ ), and the older, inherited population of 5 grains yields an age of $267.8 \pm 3.6 \mathrm{Ma}(\mathrm{MSWD}=1.4)$.

\section{DISCUSSION}

\section{TUFF DISTRIBUTION AND COMPOSITION-GONDWANAN TUFF GAP}

The abundant tuffs interbedded throughout the Karoo Supergroup strata provide the opportunity to assess $\mathrm{U}-\mathrm{Pb}$ zircon ash ages from numerous stratigraphic horizons over a $\sim 2-3 \mathrm{~km}$ thick section and offer insight into the Karoo Basin evolution. Based on field observations, the three major depocenters, Tanqua, Laingsburg, and Ripon all contain a stratigraphic interval where tuffs are not present. We note that the textural character of airfall tuffs is, in general, different above and below this observed gap in tuff deposition. Below the gap, tuffs are green, clay-rich, and typically $<10 \mathrm{~cm}$. In contrast, above the gap, tuffs are distinctly either A) white and chalky, or B) light brown and gritty/sandy with thicknesses varying between $5 \mathrm{~cm}$ up to $40 \mathrm{~cm}$. We speculate here that this "tuff gap" is similar to the "tuff gaps" reported throughout southern Gondwana (New Zealand, Australia, and Antarctica), where volcanic tuffs are rare-to-absent within otherwise ashrich strata (Veevers et al., 1994b). It remains unclear if those "tuff gaps" are related to a hiatus in volcanic activity or dilution and lack of preservation in a terrestrial depositional environment (Veevers, 2004; Retallack and Krall, 1999); these gaps, however, are thought to be synchronous across Gondwana (Veevers, 2004). We propose herein an unidentified "tuff gap" in the Karoo strata that is present in a variety of depositional environments, recorded in deep-to-marginal marine (Ecca Group) and terrestrial (Beaufort Group) sediments across the basin (Fig. 3, 4). Although the cause of the tuff gap is still poorly understood and the mechanism responsible for the evolution from clay-rich to chalky and gritty/sandy tuffs is unknown, these observations provide a distinct 
framework with three distinct ash regimes: green, clay-rich tuffs, ash absent altogether (i.e. tuff gap), and chalky/gritty tuffs.

The appearance and character of the Karoo tuffs might be due to either a 1) change in weathering conditions, 2) dilution of tuffs with clastic detritus, or 3) evolution of the volcanic ejecta from glass-dominated tuffs preserved as clay-rich tuffs, to lithic deposits, manifest as chalky or gritty/sandy tuffs. Since tuffs occur above this tuff gap, in both marginal marine and terrestrial strata deposited in both high and low energy environments, it is unlikely the ash regimes are due to clastic dilution. Additionally, the tuff gap is typically present in deep to marginal marine lowenergy depositional environments, where dilution would be unlikely. Tuffs above the gap also generally contain smaller zircon populations ( $<100$ zircon $/ \mathrm{kg}$ ) than tuffs below ( $>>100$ zircon $/ \mathrm{kg}$ ). During mineral separation, the heavy mineral composition of chalky and gritty tuffs were found to commonly contain dark, lithic grains, while clay-rich tuffs yielded few to no lithic grains and were dominated by mineral grains in the heavy mineral separates. This suggests that tuffs below the tuff gap may have been crystal-rich vitric tuffs, while the overlying volcanics are likely zircon-sparse, lithic tuffs.

\section{MAXIMUM DEPOSITIONAL AGES FROM U-PB ZIRCON ANALYSES}

Based on these new U-Pb zircon SHRIMP results, integrated with previously published data (Coney et al., 2007; Fildani et al., 2007; 2009; Rubidge et al., 2013; Lanci et al., 2013),
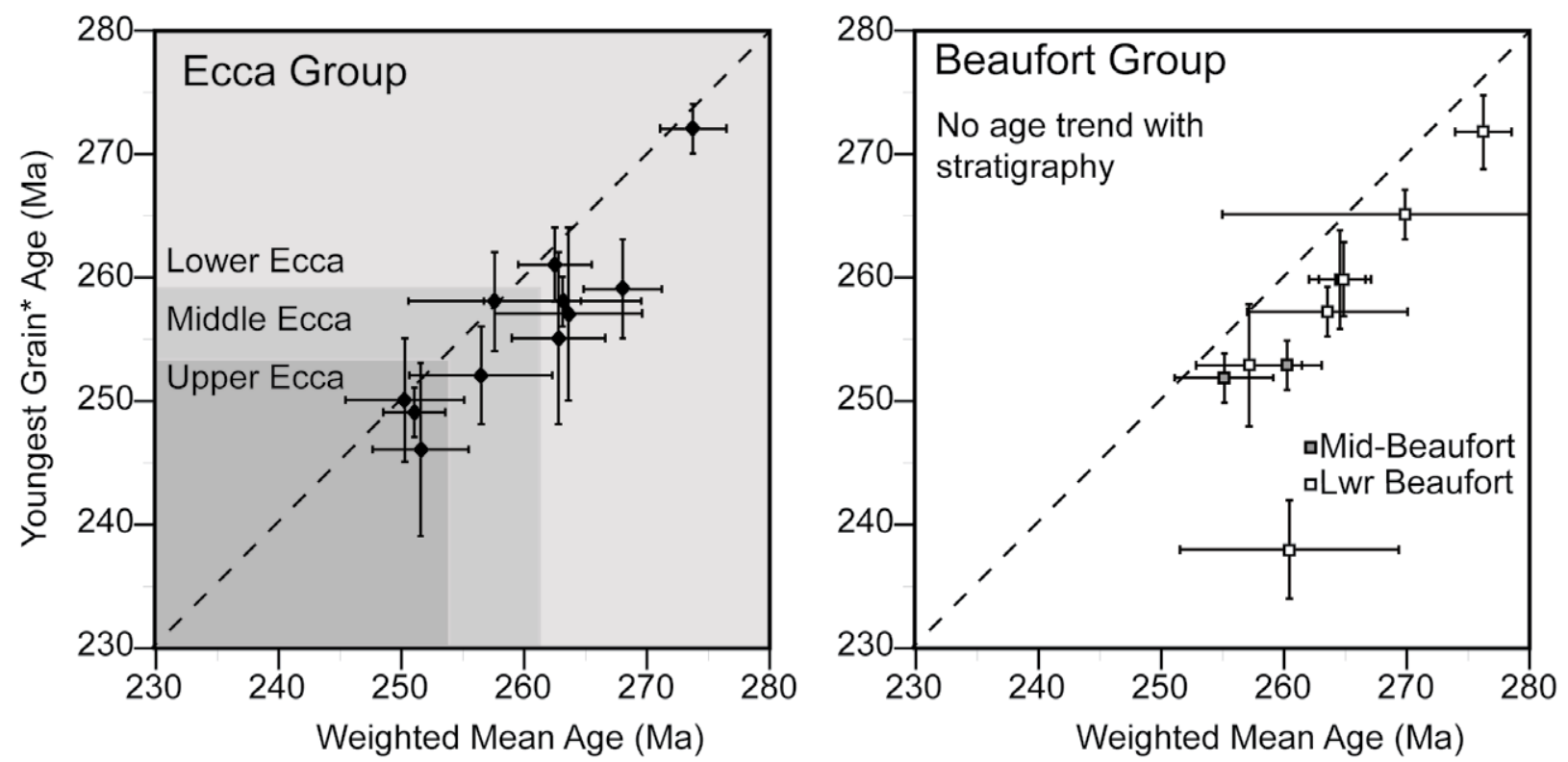

Figure 5: Youngest Grain Age (Ma) vs. Weighted Mean Age (Ma) plot (Left) shows a younging upsection of U-Pb zircon tuff ages in the Ecca Group. In the Beaufort Group (Right), no trend is observed. Two samples (13ZA72AMiddleton Fm, 13ZA76-Upper Koonap Fm) in the Middle Beaufort produce ages that are within error one of the lowest stratigraphic samples (12ZA46-an ash located directly above the "tuff gap" in the Lower Koonap Fm). No younging-upward trend, however is observed in the Beaufort Group tuffs. 
(Fig. 3, 4) strata of the Ecca Group below the regional tuff gap appear coeval across the southern margin of the basin based on ash ages, with the base of the Ecca Group 275 Ma, and consistent younging-upward stratigraphically across the basin (Fig. 5A) to the base of the ash gap at $\sim 250$ Ma, above which volcanic tuffs become rare to absent for $\sim 300-600 \mathrm{~m}$. Tuffs in the Beaufort Group above this interval consistently yield ages older than the underlying strata and do not display a younging-upward trend (Fig. 5B). Fildani et al., (2007; 2009) and Lanci et al. (2011) presented tuff ages based on extensive SHRIMP datasets $(\mathrm{N}=16, \mathrm{n}=205$ and $\mathrm{N}=4, \mathrm{n}=111$, respectively) to address the absolute age of the strata. Fildani et al. $(2007 ; 2009)$ only presented ages from the Ecca Group, while Lanci et al. (2011) only presented data from the overlying Beaufort Group. When compared to limited data that were available at the time (Coney et al., 2007), Fildani et al. (2009) observed a discrepancy in the ages of the Ecca and Beaufort Groups and used those ages to present a model for time transgressive filling across the basin. Lanci et al. (2013) suggested that the robust single crystal age data presented by Fildani et al. $(2007 ; 2009)$ were erroneously young due to $\mathrm{Pb}$-loss. The ages presented in this study are based on zircon age populations $(\mathrm{n} \geq 3$ ) to estimate ash ages, greatly minimizing the chances of the age being affected by Pb-loss (Saylor et al., 2012), but corroborate, support, and reproduced the ages estimates produced by Fildani et al. (2007; 2009), Coney et al. (2007), Weislogel et al. (2011), Rubidge et al. (2013), Lanci et al. (2013). Therefore, it is not likely that the zircon ages presented in this study have been affected by $\mathrm{Pb}$ loss because A) only concordant analyses were considered, B) ash ages are based on concordant age populations and weighted averages, C) individual results are repeatable (Fildani et al., 2007; 2009; Rubidge et al., 2013; Lanci et al., 2013) and D) the observed age inversion is present in both this study and previous studies (Fildani et al., 2007; 2009; Coney et al., 2007; Weislogel et al., 2011; Rubidge et al., 2013; Lanci et al., 2013) using a variety of analytical techniques (SHRIMP, TIMS, LA-ICPMS) and consistently occurs across the basin directly above the proposed tuff gap. No relationship between $\mathrm{U}$ concentration and age was observed, further suggesting that $\mathrm{Pb}-\mathrm{loss}$ from U-decay, lattice damage and diffusion has not affected concordant zircon ages (Kryza et al., 2012). If Pb-loss is believed to be the cause of the observed contradictory ages, then Pb-loss must be more significant and pervasive in the Ecca Group than in the Beaufort Group, which would require a stratigraphically selective Pb-loss mechanism that disturbed the isotopic systems of some tuffs, while leaving others in the overlying strata effectively unaltered. Therefore, we interpret the weighted mean $\mathrm{U}-\mathrm{Pb}$ zircon ages to represent a maximum depositional age of the airfall ash and will explore the implications of these new age controls across the $>600 \mathrm{~km}$ long southern margin of the Karoo Basin.

The abrupt appearance of older ages is restricted to the strata above the observed tuff gap. Possible mechanisms that could cause these older, seemingly anomalous tuff ages include: 
1) structural juxtaposition of older strata (fluvial) over younger (marine); 2) time-transgressive facies tracts producing synchronous marine and terrestrial deposition; 3) detrital reworking and contamination in high-energy, terrestrial environments; and 4) lack of co-eruptive zircon in earlyto-mid Triassic tuffs.

No field evidence by any workers in the Karoo Basin has been observed or reported to identify tectonic structures that could render older-over-younger strata over 1000's of square kilometers to cause inversion of zircon ages in the tuffs. Tanqua depocenter strata are flat-lying and undeformed and Beaufort and Ecca Group strata in the Laingsburg and Ripon depocenter are deformed by broad, upright folds; any repetition of mapped strata is locally isolated.

Alternately, time-transgressive facies deposition could create the observed age inversion. Previous models for basin infilling based on paleoflow and provenance analysis concluded that sediment was transported into the basin mainly from the south; this model would predict stratigraphic younging of ash beds northward (Veevers et al., 1994a; Rubidge et al., 2000; Flint et al., 2011). However, this scenario appears to conflict with the observed older zircon ages in Beaufort Group tuffs that lie to the north of the younger Ecca Group ash samples. Fildani et al. (2009) suggested diachronous filling of the basin from east to west, with terrestrial deposition in the east being coeval with deep marine conditions in the west. The new results from the Ripon depocenter, indicate contemporaneous marine deposition over $>600 \mathrm{~km}$ across the southern margin of the Karoo Basin and do not support this scenario unless we hypothesize a highly segmented basin. Recent studies of the Beaufort Group (Lanci et al., 2013; Wilson et al., 2014) report consistent paleocurrents to the NE, supporting sediment dispersal pattern for the whole deep water to fluvial section. For diachronous filling to produce the observed age inversion, marine conditions in the southern basin would need to be coeval with or postdate fluvial deposition to the north. While no evidence in the stratigraphic record has been directly identified to support either of these scenarios, more age constraints from across the basin are required to better understand basin-wide sedimentation patterns.

Here, we consider the possibility that some tuffs within the Karoo Supergroup do not contain coherent populations of terminal-phase, co-eruptive zircon. In this scenario, a terminalphase zircon population may be present, but is diluted by older zircon due to (1) sedimentary reworking of older ash or clastic material within younger ash deposits, (2) inclusion of older xenocrystic or co-magmatic zircon residing within the magmatic system or (3) incorporation of older lithic volcanic material from the volcanic carapace during eruption. One Beaufort Group ash sample (12ZA46) showed signs of detrital contamination, with 5 of 10 zircon grains being significantly older $(>280 \mathrm{Ma})$ than the youngest coherent population (257.3 $\pm 4.3 \mathrm{Ma}$; $\mathrm{n}=4)$. Air- 

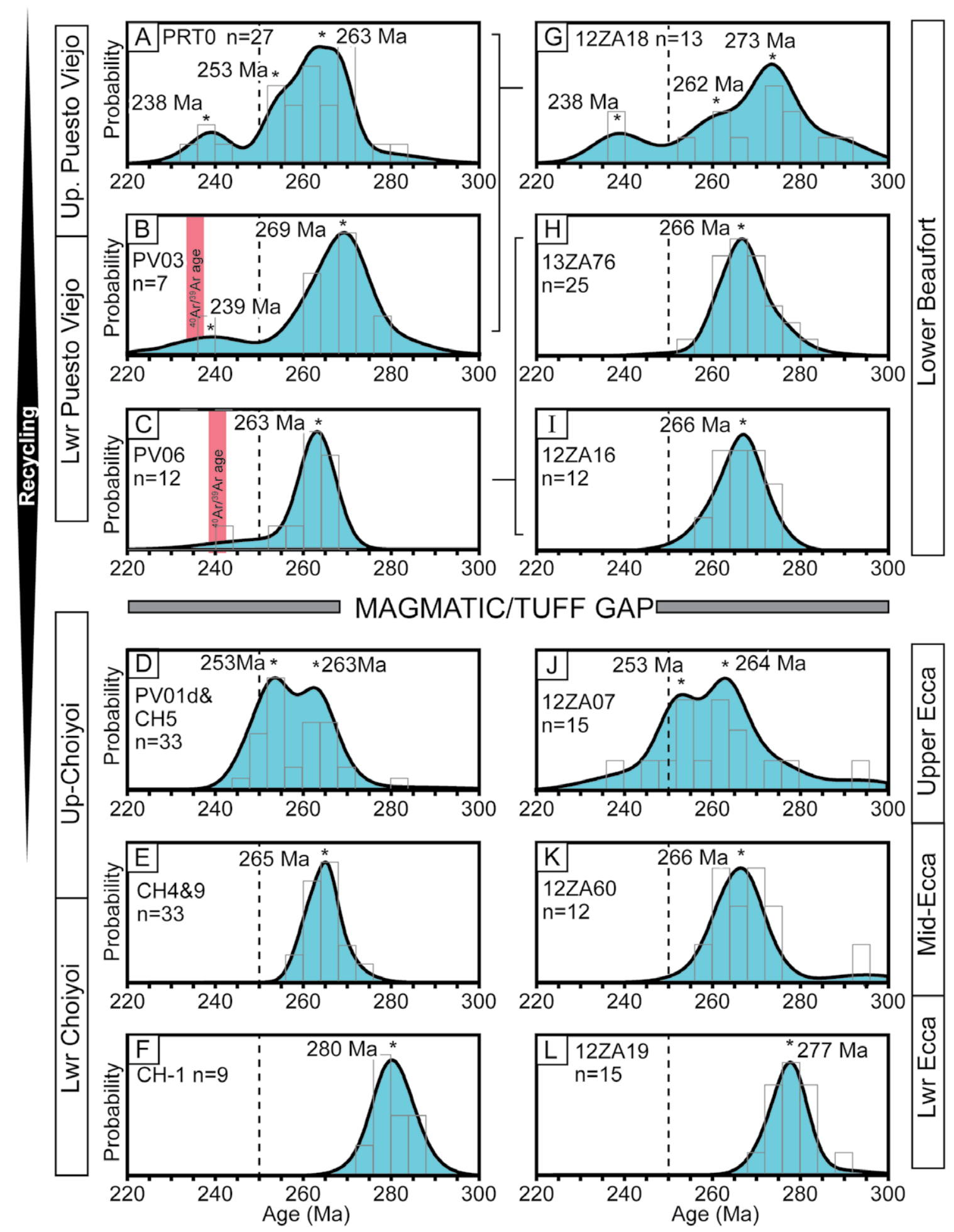

Figure 6: Correlation of KDE plots from the Puesto Viejo (A, B, C; Spalletti et al., 2008; Domeier et al., 2011) and Choiyoi (D, E, F) volcanic suites to comparable KDE signatures in interbedded tuffs of the Karoo Supergroup. Beaufort Group (G, H, I) samples show similar KDE signatures to the Puesto Viejo volcanics, while the underlying Ecca Group samples (J, K, L) matches the stratigraphic trend observed in the Choiyoi Group. The uppermost Choiyoi samples contain peaks at 253 and $263 \mathrm{Ma}$, compared to 253 and $264 \mathrm{Ma}$ in the Ecca Group directly below the base of the tuff gap. 
fall tuffs deposited in fluvial depositional environments, such as the Beaufort Group depositional system, are particularly prone to reworking and detrital mixing by overland flows, pedogenesis and bioturbation. While it is difficult to assess the role of clastic dilution and terrestrial reworking without resolving the detrital zircon populations of adjacent siliciclastic units, tuffs within the Beaufort Group retain an ash lithology and show no physical signs of detrital reworking. If tuffs were significantly contaminated with detrital zircon, that would require significant reworking with a large volume of clastic material such that the ash lithology would not be retained.

In addition, with 9 ash ages for the Beaufort Group from this study and 4 tuffs from Lanci et al. (2013), 113 grains yield a Permian age, yet only 4 moderately concordant Triassic grains have been recovered (12ZA18 shown in Fig.6G), compared to 253 concordant Permian grains and 26 concordant Triassic grains in the 13 ages tuffs within the Ecca Group from this study and 8 tuffs from Fildani et al. $(2007 ; 2009)$. Of the 26 concordant Triassic ages in the Ecca Group, 18 were obtained from tuffs just below the presumed tuff gap (12ZA07, CVX12, 12ZA23, 12ZA61). These four samples all yield $250-251$ Ma weighted mean ages, which coincides with the basal age of the tuff gap ( $251 \mathrm{Ma}$ ) elsewhere in Gondwana (Veevers et al., 1994b). Since the base of the tuff gap is approximately the boundary between the Permian and Triassic, ages just below this interval would be expected to straddle the boundary, with a range of $249-254 \mathrm{Ma}$ ages, which is observed in Ecca tuffs and is compatible with our age interpretation. Furthermore, the absence of a large, Triassic zircon population in Beaufort tuffs suggests limited availability of co-eruptive, autocrystic zircons in the Beaufort Group. Magmatic recycling is also compatible with the observation of shared recycled populations within the weighted averages of ash zircon populations, where 7 tuffs in this study contained a 267-268 Ma tuff population ( $\mathrm{P}_{1}$ of 12ZA16, 12ZA55, SUTH, and $\mathrm{P}_{2}$ of 12ZA23, 12ZA60, 13ZA72, 13ZA76) and 7 tuffs contained a 261-264 Ma tuff population $\left(\mathrm{P}_{1}\right.$ of 12ZA10, 12ZA18, 12ZA54, 12ZA60, 13ZA67, 13ZA76, and $\mathrm{P}_{2}$ of 12ZA61). These inherited populations likely represent zircon crystallization events in the magmatic source of the tuffs and may be present in any subsequently erupted ash. A similar observation has been made in proximal volcanic deposits in the Southern Pyrenees, where distinct zircon crystallization events are represented in subsequent eruption events (Pereira et al., 2014). Recycling is further suggested by the dominance of 25 concordant Ordovician xenocrysts in Karoo tuffs from this study alone, which is most evident sample 12ZA45, where the only coherent age population $(n=4$ of 6 concordant analyses) consisted of $\sim 453$ Ma grains.

Recycling of antecrystic and xenocrystic zircon in Late Permian-Triassic volcanics is recognized in correlative volcanics in South American (Spalletti et al., 2008; Domeier et al., 2011). Two, successive magmatic suites in South America, the Permian Choiyoi Group and Triassic Puesto Viejo Group record the same volcanism responsible for tuffs in the Karoo Supergroup. The 
Permian Choiyoi Group yields well defined U-Pb zircon age peaks between 280 to $253 \mathrm{Ma}$ (Fig. $6 \mathrm{D}, \mathrm{E}, \mathrm{F})$ with signs of zircon recycling restricted to the uppermost Upper Choiyoi Group. A tuff from the Upper Choiyoi was found to be dominated by 276 Ma zircon (SM-1; Rocha-Campos et al., 2006) and also contain a distinct subpopulation of 253 Ma zircon ( $\mathrm{n}=4$; Rocha-Campos et al., 2006). This $\sim 253 \mathrm{Ma}$ age reflects the age of the last phases of Choiyoi volcanism (Kleiman and Japas, 2009). Zircon recycling intensifies within the Triassic Puesto Viejo Group, which contain more complex zircon populations (Fig. 6A, B, C). Published U-Pb zircon from the lowest Puesto Viejo Group (PV06 of Domeier et al., 2011; PRT0 of Spalletti et al., 2008 from the Potrerillos Fm, a coeval, stratigraphic equivalent of the Puesto Viejo Group [Ottone et al., 2014]) show that samples contain dominant $\sim 260-280$ Ma populations with few to no Triassic grains. ${ }^{40} \mathrm{Ar} /{ }^{39} \mathrm{Ar}$ feldspar ages for the same intervals range between 239 to $235 \mathrm{Ma}$, suggesting a $>20 \mathrm{~m}$.y. discrepancy between $\mathrm{U}-\mathrm{Pb}$ zircon and ${ }^{40} \mathrm{Ar} /{ }^{39} \mathrm{Ar}$ feldspar geochronology systems. Samples from the mid-to-upper Puesto Viejo Group contained significantly more Triassic grains (PRT1, PRT2 of Spalletti et al., 2008; Ottone et al., 2014), yielding weighted mean ages of 239-230 which are within error of correlative ${ }^{40} \mathrm{Ar} /{ }^{39} \mathrm{Ar}$ feldspar ages. The high proportion of Permian grains and discrepancies between $\mathrm{U}-\mathrm{Pb}$ zircon and ${ }^{40} \mathrm{Ar} /{ }^{39} \mathrm{Ar}$ ages in the lowest Puesto Viejo Group led Domeier et al. (2011) to suggest that these volcanics were dominated by recycled, xenocrystic zircon. These observations were further used to propose that the Puesto Viejo magma chamber was volumetrically too small to generate new zircon grains (Domeier et al., 2011).

When $\mathrm{U}-\mathrm{Pb}$ zircon spectra from Karoo Supergroup tuffs (Fig. 6G-L) are compared to age equivalent volcanics in South America (Fig. 6A-F), the impact of zircon recycling on tuff geochronology can be observed. Lower Choiyoi volcanic samples (Fig. 6E-F; Rocha-Campos et al., 2011) contain a single, cohesive zircon population, which was resolved in samples from the Lower-Middle Ecca Group. Samples from the uppermost Upper Choiyoi (PV01d from Domeier et al., 2010; CH-05 from Rocha-Campos et al., 2011; SM-1 from Rocha-Campos et al., 2006data unpublished), however typically contain a Late Permian zircon population ( $253 \mathrm{Ma})$ that is distinct from an older Middle-to-Late Permian populations ( 263-273 Ma). The KDE for available data from the uppermost Upper Choiyoi volcanics (Fig. 6D) is remarkably similar to Upper Ecca Group tuffs (Fig. 6J), with local maxima at $\sim 253$ and $\sim 263$ Ma. Comparison of U-Pb zircon and ${ }^{40} \mathrm{Ar} /{ }^{39} \mathrm{Ar}$ ages (Fig. 6B, C) for the Lower Puesto Viejo volcanics demonstrate that Early to Middle Triassic volcanics do not contain dominant, co-eruptive zircon populations, but are rich in older, mid-Permian zircon (Fig. 6C). This trend is observed in samples from the Lower Beaufort (Fig. $6 \mathrm{H}, \mathrm{I})$. In subsequent Puesto Viejo volcanics, small, coherent populations of co-eruptive zircon become observable (Fig. 6A, B), which can also be observed in zircon populations from Lower Beaufort tuffs (Fig. 6G). Based on the similarity of zircon population distributions, weighted mean 


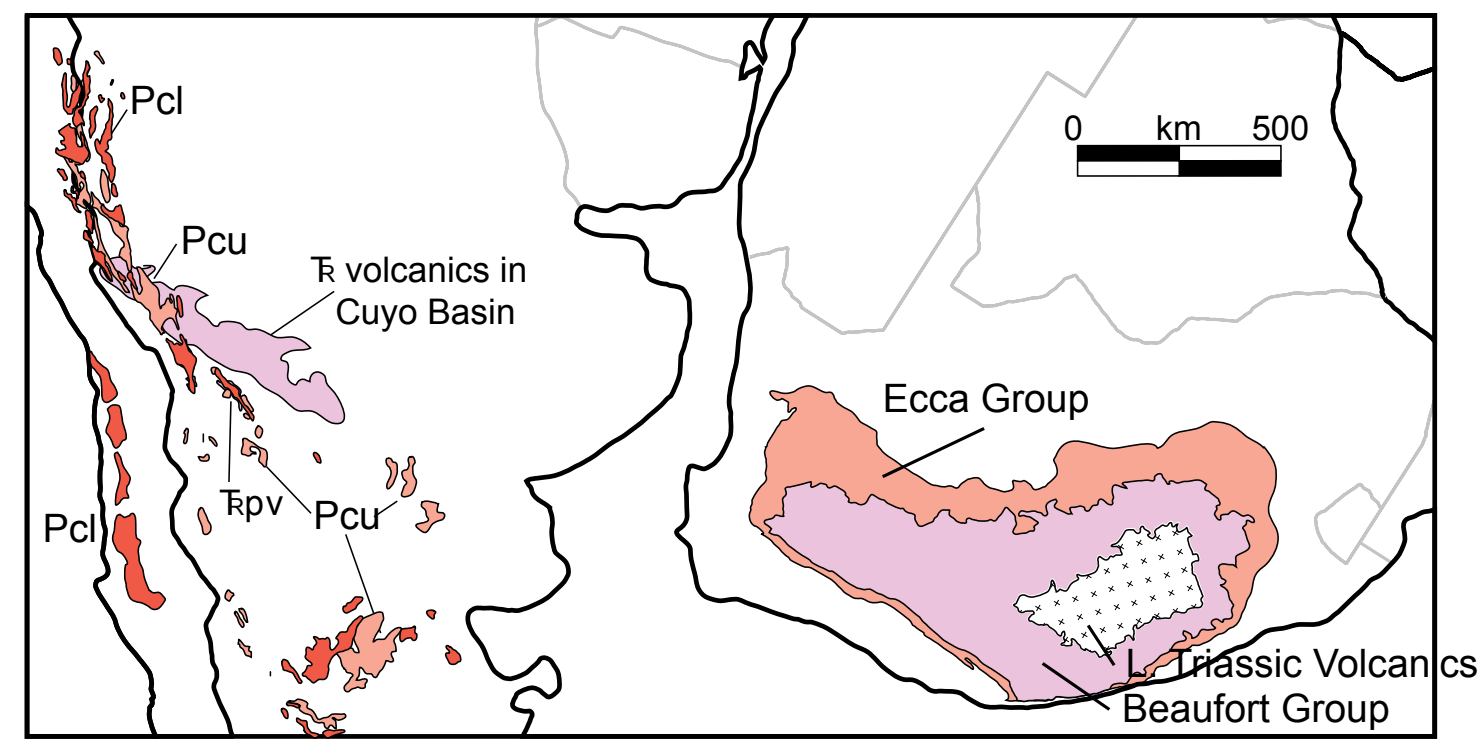

Correlation of Units

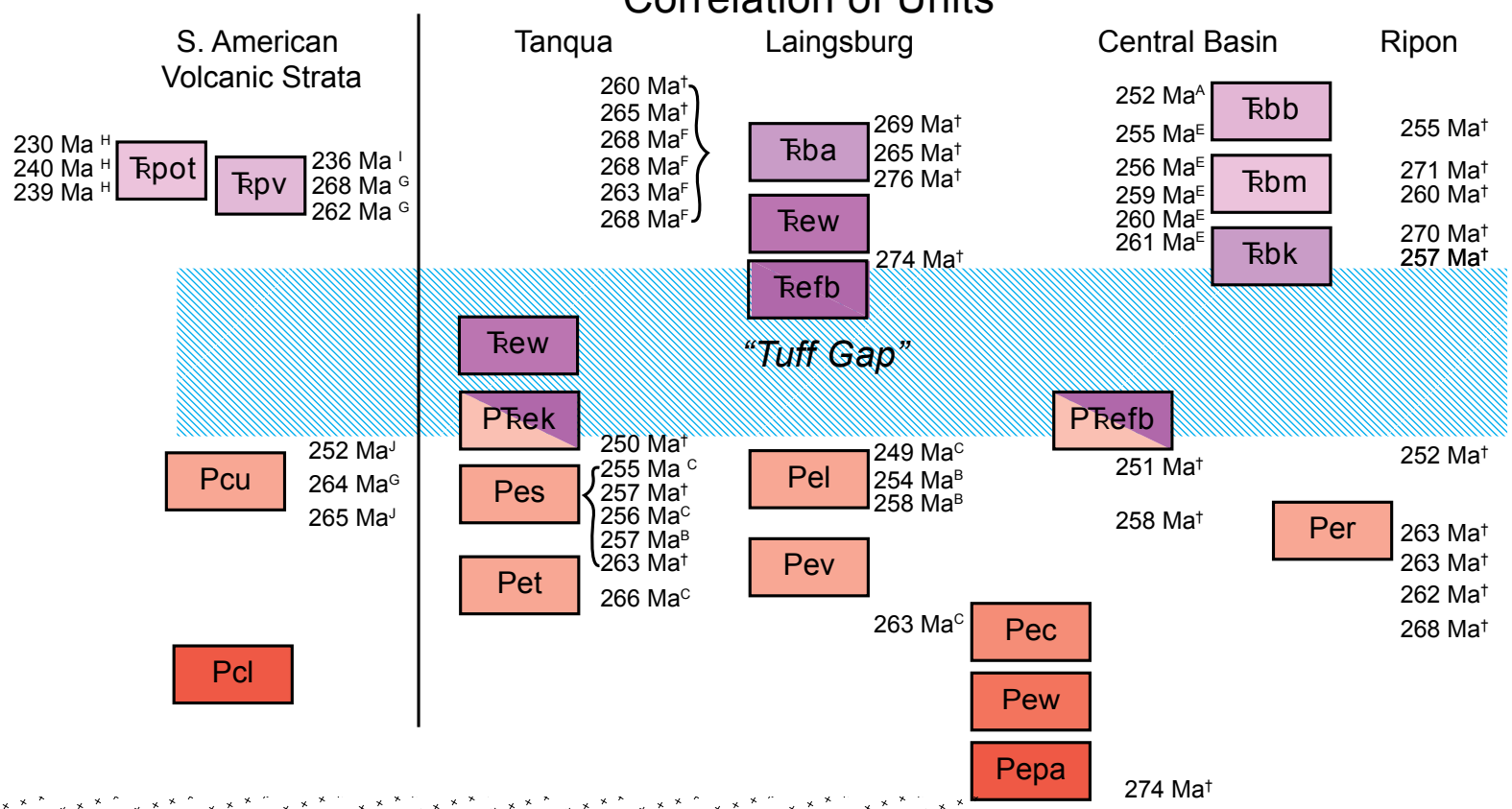

\begin{tabular}{|c|c|c|c|c|c|c|}
\hline \multicolumn{5}{|c|}{ Explanation } & Pel & Laingsburg Fm \\
\hline \multirow{6}{*}{ 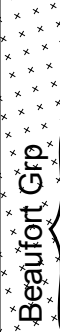 } & Kpot & \multirow{2}{*}{\multicolumn{3}{|c|}{$\begin{array}{l}\text { Potrerillos Fm } \\
\text { Puesto Viejo Volcanics }\end{array}$}} & Pes & Skoorsteenberg Fm \\
\hline & Kpv & & & & Per & Ripon Fm \\
\hline & $\mathrm{Kbb}$ & \multirow{3}{*}{\multicolumn{3}{|c|}{$\begin{array}{ll}\text { Balfour Fm } & \text { 음 } \\
\text { Middleton Fm } & \text { ூㅓ } \\
\text { Koonap Fm } & \end{array}$}} & Pev & Vischkuil Fm \\
\hline & Rbm & & & & Pet & Tierberg Fm \\
\hline & Rbk & & & & $\mathrm{Pec}$ & Collingham Fm \\
\hline & Kba & \multicolumn{3}{|c|}{ Abrahamskraal Fm } & Pewh & Whitehill Fm \\
\hline \multirow{3}{*}{$\begin{array}{l}\frac{0}{0} \\
\text { ত্ } \\
\text { ய }\end{array}$} & kew & \multicolumn{3}{|c|}{ Waterford Fm } & Рepa & Prince Albert Fm \\
\hline & $\overline{\text { Refb }}$ & PRefb & For & $\mathrm{Fm}$ & Pcu & Choiyoi Grp (Upper) \\
\hline & PRek & \multicolumn{3}{|c|}{ Kookfontein Fm } & $\mathrm{Pcl}$ & Choiyoi Grp (Lower) \\
\hline
\end{tabular}

Figure 7: Simplified Geologic Map of the Choiyoi Group (Upper and Lower), Puesto Viejo Volcanics and coeval equivalents (Potrerillos Fm), and Karoo Supergroup, with a detailed Correlation of Units showing time equivalent stratigraphy and relevant age controls from Figure 3. South American geology from Kleiman and Japas, 2009; Spalletti et al., 2008; and Ottone et al., 2014. 
ages, and stratigraphic position relative to the overlying magmatic/tuff gap, we propose several age correlations (Fig. 7):

1. Lowest Ecca Group tuffs (within the Prince Albert, Whitehill Fms) are age equivalent to the Early-Middle Permian Lower Choiyoi Group (>265 Ma).

2. Mid-Ecca Group tuffs (within the Collingham, Vischkuil, Skoorsteenberg, Laingsburg, Ripon Fms.) are age equivalent to the upper, Lower Choiyoi and lowest, Upper Choiyoi Group rocks $(\sim 265-255)$.

3. Upper Ecca Group tuffs (Kookfontein, Fort Brown Fms) are age equivalent to the late Upper Choiyoi Group (253 Ma).

4. The overlying Lower Beaufort Group tuffs are dominated by recycled zircon grains, which suggest they are age equivalent with Puesto Viejo volcanism (241-235 Ma).

5. The Tuff Gap proposed in this study (Fig. 3, 4, 7), could represent magmatic quiescence between Choiyoi and Puesto Viejo magmatic activity (252-241 Ma).

\section{IMPLICATIONS FOR MAGMATISM IN SOUTHERN GONDWANA}

Zircon is known to be present in variable concentrations in different tectonographic terranes (discussed as "zircon fertility" in Moecher and Samson, 2006). Therefore a zircon-rich terrane would be overrepresented in any zircon geochronology study compared to a zircon-sparse or zirconpoor terrane. This is most commonly applied to understand the geologic bias in detrital zircon provenance studies. The same mechanism, however, may create bias in the study of a magmatic system if certain magmatic systems produce few to no zircon, while others generate large volumes of zircon. The Southern Gondwanan magmatic system as recorded in South America and the Karoo Basin appears to have consisted of three distinct pulses of magmatism: 1) zircon-rich, subduction and orogenic collapse drive magmatism that erupted crystalliferous, vitric tuffs prior to $\sim 252 \mathrm{Ma}$, 2) magmatic and volcanic quiescence from 252-241 Ma, and 3) renewed magmatism driven by extensional rifting that resulted in recycling of older crustal materials and eruption of lithic tuffs. Crystalline basement rocks from the Antarctic Peninsula (Riley et al., 2012), which would have been tectonically adjacent to South Africa within Gondwana (Fig. 1A), provide further insight into zircon crystallization over time (Fig. 8). Permian-Cretaceous basement from the Antarctic Peninsula contain co-emplacement and recycled igneous zircon, as well and metamorphic zircon that record Permian-Triassic metamorphism. When considering only low U/Th $(<10 ; n=62)$, which likely represents igneous zircon (Hoskin and Black, 2000), there is a distinct pattern that is strikingly similar to the zircon trends observed in South America and South Africa. There are two 


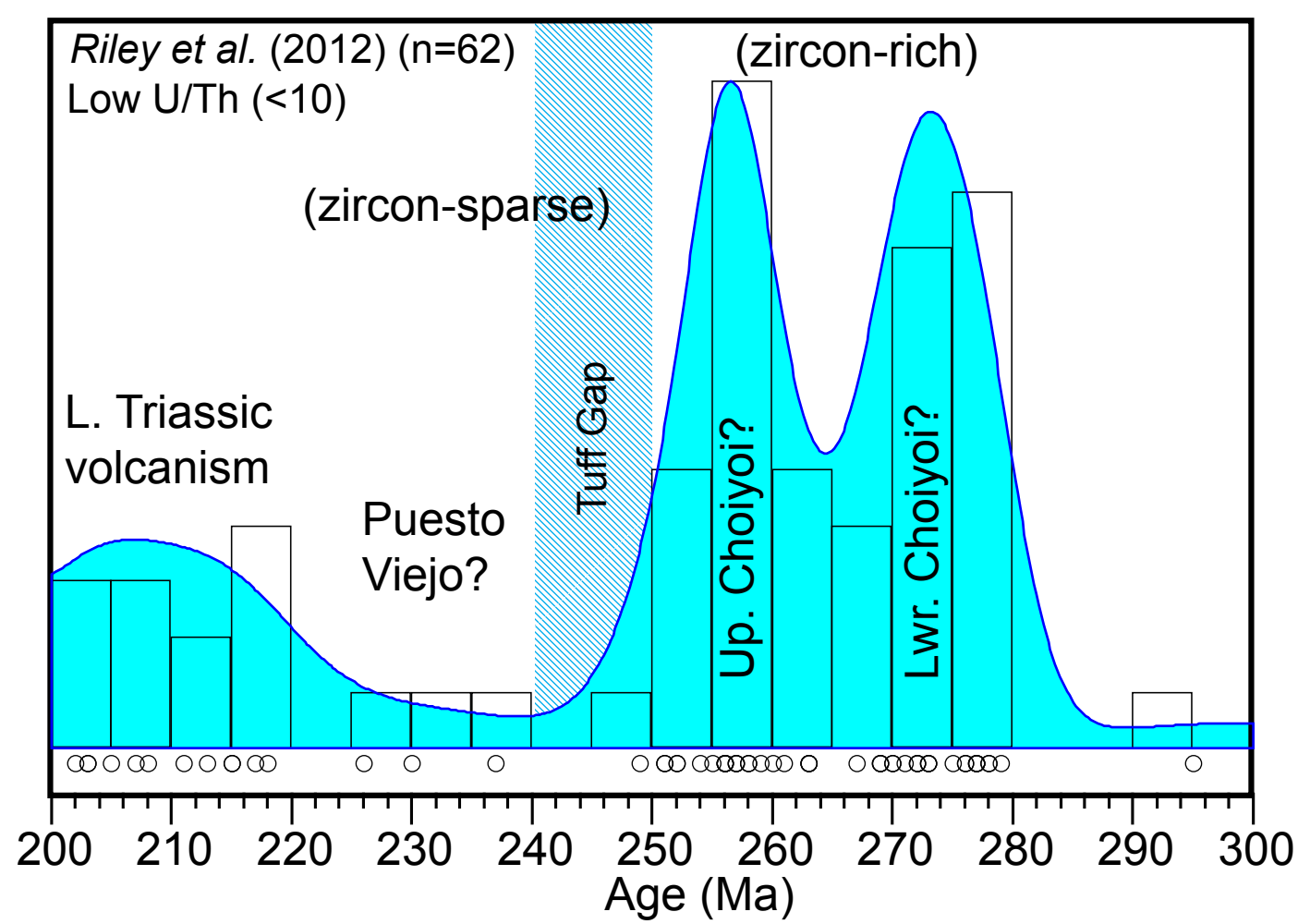

Figure 8: KDE age distribution of igneous $(\mathrm{U} / \mathrm{Th}<10)$ Permian-Triassic zircon from Gondwanan crystalline basement in the Antarctic Peninsula (Riley et al., 2012). The peaks of zircon ages represent pulses of igneous zircon crystallization. Two peaks at $\sim 272$ and $\sim 255 \mathrm{Ma}$ are coeval with Lower and Upper Choiyoi volcanism, no zircon are found in the time interval of the tuff gap, and few, sparse zircon correlate to Puesto Viejo volcanism, despite known Early Triassic volcanism in Southern Gondwana.

Permian spikes of zircon represented in the Antarctic samples at $\sim 272$ and $\sim 255 \mathrm{Ma}$. The roughly correlate to the Lower (290-265 Ma) and Upper (270-250 Ma) Choiyoi Group volcanic suites and the latter pulse with the tuffs of the Ecca Group. Only one zircon lies within the range of the tuff gap, but this grain also is within error or the $\sim 255$ Ma peak, therefore, there are effectively no zircon produced during this interval, which likely reflects magmatic quiescence. The Antarctic Peninsula samples only yield 3 grains that correlate with Puesto Viejo magmatism (240-220 Ma). Despite known volcanism during this time, the sparse presence of such a small population suggests that very few zircon were crystallized during this period. These observations, along with the lack of co-eruptive zircon in South American and Karoo Basin volcanics strongly suggest that zircon production in Southern Gondwanan was subdued in the Early Triassic across the western half of the margin. The lack of co-eruptive zircon, therefore, may be a super-regional phenomenon, that might affect more areas throughout Gondwana, particularly in the Early Triassic, thereby hindering $\mathrm{U}-\mathrm{Pb}$ zircon geochronology in Early Triassic volcanics. 


\section{SUMMARY}

Using 469 new single-grain analyses, we used coherent age populations to determine 22 $\mathrm{U}-\mathrm{Pb}$ zircon tuff ages in 4 stratigraphic sections of the lower Karoo Supergroup across the Karoo Basin. Regionally, tuffs within the terrestrial Beaufort Group consistently produce ages that are older than the underlying marine Ecca Group, which can be observed in multiple studies (Coney et al., 2007; Fildani et al., 2007; 2009; Rubidge et al., 2013; Lanci et al., 2013) using different analytical techniques (SHRIMP, TIMS, LA-ICP-MS). The reproducibility of tuff ages in the marine section and internally consistent age for the base of the tuff gap suggests that ages below a proposed regional tuff gap may provide reliable chronostratigraphic control, while tuffs above the tuff gap yield chaotic ages that pre-date deposition (Fig. 5). We propose that post-depositional reworking combined with a lack of terminal phase, volcanic zircon in distal airfall tuffs within the Beaufort Group may be responsible for the inversion of U-Pb zircon ages. Zircon recycling is observed in correlative proximal volcanic tuffs in Permo-Triassic basins of South America, corroborating this hypothesis. The zircon U-Pb ages from tuffs in the Beaufort Group should therefore be considered as constraints on maximum depositional ages, not as a representation of the actual depositional age (i.e. "golden spike" ages). Our proposed explanation brings together data considered thus far puzzling and contradictory, and is compatible with recent observations in other long-lived arc to post-orogenic systems that show protracted zircon recycling (Pereira et al., 2014). Our observations support recent evidence from South America that the absolute ages assigned to Gondwanan biozones may be erroneously old (Ottone et al., 2014). Our new data are in agreement with all recently published ages (Fildani et al., 2007, 2009; Rubidge et al., 2013; Lanci et al., 2013) and demonstrate the importance of considering the magmatic history of a volcanic source when interpreting $\mathrm{U}-\mathrm{Pb}$ zircon datasets from tuffs to estimate maximum depositional ages. These new data illustrate how tuff geochronology can, at times, be ambiguous when using a limited dataset. By compiling a regionally extensive study and understanding the nature of volcanism, however, the ambiguity might be reduced, resulting in more competent stratigraphic age controls.

\section{ACKNOWLEDGEMENTS}

Funding was provided through grants from West Virginia University, American Association of Petroleum Geologists, Society for Sedimentary Geology, Geological Society of America, and Dr. R. Shumaker to McKay and Weislogel. Analytical support was provided by Dr. Matt Coble, of the Stanford Univ./USGS SUMAC SHRIMP Lab. This manuscript was greatly improved by reviews from Dr. E.G. Ottone, Dr. Brian Romans, an anonymous reviewer, Kathleen Kingry, and Dr. Angela Hessler. 


\section{REFERENCES}

Barth, A.P. and Wooden, J.J., 2006, Timing of magmatism following initial convergence at a passive margin, southwestern U.S. Cordillera, and ages of lower crustal magma sources: Journal of Geology, v. 114, p. 231-245, doi:10.1086/499573.

Black, L.P., and 9 others, 2004, Improved 206Pb/238U microprobe geochronology by the monitoring of a trace-element-related matrix effect; SHRIMP, ID-TIMS, ELA-ICP-MS and oxygen isotope documentation for a series of zircon standards: Chem. Geology, v. 205, p. 115-140.

Bouma, A.H. and Wickens, H. deV., 1994, Tanqua Karoo, ancient analog for fine-grained submarine fans, in Weimer, P., Bouma, A.H., and Perkins, B.F., eds., Submarine Fans and Turbidite Systems: Sequence Stratigraphy, Reservoir Architecture, and Production Characteristics: SEPM, Gulf Coasts Section, 15th Annual Research Conference, p. 23-34.

Bowring, S.A., Schmitz, M.D., 2003, High precision zircon geochronology and the stratigraphic record: in Hanchar, J.M., Hoskins, P.W.O. Zircon: Experiments, Isotopes, and Trace Element Investigations Reviews in Mineralogy and Geochemistry 53, 305-326.

Castiñeiras, P., Díaz García, F., Gómez Barreiro, J., 2010, REE-assisted U-Pb age (SHRIMP) of an anatectic granodiorite: Constraints on the evolution of the A Silva granodiorite, Iberian allochthonous complexes, Lithos, v. 116, p. 153-166.

Catuneanu, O., Hancox, P.J., Cairncross, B., Rubidge, B.S., 2002, Foredeep submarine fans and forebulge deltas: orogenic off-loading in the underfilled Karoo Basin, J. Afr. Earth Sci., v. $35,489-502$.

Coleman, D.S., Gray, W., Glazer, A.F., 2004, Rethinking the emplacement and evolution of zoned plutons: geochronologic evidence for incremental assembly of the Tuolumne Intrusive Suite, California, Geology, 32, 433-436.

Compston, W. \& Gallagher, K., 2012, New SHRIMP zircon ages from tuffs within the British Palaeozoic stratotypes, Gondwana Research, 21, p. 719-727.

Coney, L., and 8 others, 2007, Geochemical and mineralogical investigation of the PermianTriassic boundary in the continental realm of the southern Karoo Basin, South Africa, Palaeoworld, v. 16, p. 67-104.

Crowell, J.C., 1978, Gondwanan glaciation, cyclothems, continental positioning, and climate change, American Journal of Science, v. 278, p. 1315-1372. 
Dickinson, W.R., and Gehrels, G.E., 2008, Sediment delivery to the Cordilleran foreland basin: Insights from $\mathrm{U}-\mathrm{Pb}$ ages of detrital zircons in Upper Jurassic and Cretaceous strata of the Colorado Plateau, American Journal of Science, v. 308, no. 10, 1041-1082.

Domeier, M., Van der Voo, R., Tomezzoli, R.N., Tohver, E., Hendriks, B.W.H., Torsvik, T.H., Vizan, H., Dominguez, A., Support for an "A-type" Pangea reconstruction from highfidelity Late Permian and Early to Middle Triassic paleomagnetic data from Argentina, Journal of Geophysical Research, vol. 116, B12114, 26 p., doi:10.1029/2011JB008495

Fildani, A., Drinkwater, N.J., Weislogel, A., McHargue, T., Hodgson, D.M., Flint, S.S., 2007, Age controls on the Tanqua and Laingsburg deep-water systems: New insights on the evolution and sedimentary fill of the Karoo Basin, South Africa, J. Sediment. Res., v. 77, p. 901-908.

Fildani, A., Weislogel, A., Drinkwater, N.J., McHargue, T., Tankard, A., Wooden, J., Hodgson, D., Flint, S., 2009, U-Pb zircon ages from the southwestern Karoo Basin, South AfricaImplications for the Permian-Triassic boundary, Geology, v. 37, p. 719-722.

Flint, S.S., and 9 others, 2011, Depositional architecture and sequence stratigraphy of the Karoo basin floor to shelf edge succession, Laingsburg depocentre, South Africa, Marine and Petroleum Geology, v. 28, p. 658-674.

Gastaldo, R.A., Adendorff, R., Bamford, M., Labandeira, C.C., Neveling, J., Sims, H., 2005, Taphonomic trends of macrofloral assemblages across the Permian-Triassic boundary, Karoo Basin, South Africa, Palaios, v. 20, p. 479-497.

Groenewald, G.H. and Kitching, J.W., 1995, Biostratigraphy of the Lystrosaurus assemblage zone, in Rubidge, B.S. (Ed.), Reptilian Biostratigraphy of the Permian-Triassic Beaufort Group (Karoo Supergroup): S. Af. Commission on Strat., Biostrat. Series 1, p. 29-34.

Hodgson, D.M., Di Celma, C., Brunt, R.L., Flint, S.S., 2011. Submarine slope degradation and aggradation and the stratigraphic evolution of channel-Levee systems. Journal of the Geological Society, 168, 625-628.

Holt, P.J., Allen, M.B., van Hunen, J., 2015, Basin formation by thermal subsidence of accretionary orogens, Tectonophysics, v. 639, 132-143.

Hoskin, P.W.O., and Black, L.P., 2000, Metamorphic zircon formation by solid-state recrystallization of protolith igneous zircon, J. Metamorphic Geology, 18, 423-439.

Jones, G.E.D., Hodgson, D.M., Flint, S.S., 2013, Contrast in the process response of stacked clinothems to the shelf-slope rollover. Geosphere, 9, 299-316. doi: 10.1130/GES00796.1

Kleiman, L. E., Japas, M.S., 2009, The Choiyoi volcanic province at $34^{\circ} \mathrm{S}-36^{\circ} \mathrm{S}$ (San Rafael, Mendoza, Argentina): Implications for the Late Palaeozoic evolution of the southwestern 
margin of Gondwana, Tectonophysics, v. 473, 283-299.

Kryza, R., Crowley, Q.G., Larionov, A., Pin, C., Oberc-Dziedzic, T., Mochnacka, K., 2012, Chemical abrasion applied to SHRIMP zircon geochronology: An example from Variscan Karkonosze Granite (Sudetes, SW Poland), Gondwana Research, 21, 757-767.

Lanci, L., Tohver, E., Wilson, A., Flint, S., 2013, Upper Permian magnetic stratigraphy of the lower Beaufort Group, Karoo Basin, Earth and Planetary Science Letters, 375, 123-134.

Lawver, L.A., Gahagan, L.M., Coffin, M.F., 1992, The development of paleoseaways around Antarctica, Antarctic Research Series, v. 56, p. 7-30.

Lopez-Gamundi, O., 2006, Permian plate margin volcanism and tuffs in adjacent basins of west Gondwana: Age constraints and common characteristics, J. South Amer. Earth Sci., v. 22, 227-238.

Lopez-Gamundi, O.R., and Rossello, E.A., 1998, Basin fill evolution and paleotectonic patterns along the Samfrau geoscyncline: the Sauce Grande basin-Ventana foldbelt (Argentina) and Karoo basin-Cape foldbelt (South Africa) revisited, Geol. Rundsch., v. 86, 819-834.

Lopez-Gamundi O., Fildani, A., Weislogel, A., Rossello, E., 2013, The age of the Tunas formation in the Sauce Grande basin-Ventana foldbelt (Argentina): Implications for the Permian evolution of the southwestern margin of Gondwana, Journal of South American Earth Sciences, 45, 250-258.

Ludwig, K., 2008, A geochronological toolkit for Microsoft Excel: Berkeley Geochronology Ctr. Special Publication, v. 4, 77 p.

Ludwig, K., 2009, SQUID 2: A user's manual, rev. 12 Apr, 2009, Berkeley Geochronology Center Special Publication, v. 5, 110 p.

Miller, J.S., Matzel, J.E.P., Miller, C.F., Burgess, S.D., Miller, R.B., 2007, Zircon growth and recycling during the assembly of large, composite arc plutons, Journal of Volcanology and Geothermal Research, 167, 282-299.

Moecher, D.P., Samson, S.D., 2006, Differential zircon fertility of source terranes and natural bias in the detrital zircon record: implications for sedimentary provenance analysis, Early and Planetary Science Letters, 247, 252-266.

Ottone, E.G., Monti, M., Marsicano, C.A., de la Fuente, M.S., Naipauer, M., Armstrong, R., Mancuso, A.C., 2014, A new Late Triassic age for the Puesto Viejo Group (San Rafael depocenter, Argentina): SHRIMP U-Pb zircon dating and biostratigraphic correlations 
across southern Gondwana, Journal of S. American Earth Sciences, vol. 56, p. 186-199

Pankhurst, R.J., Rapeka, C.W., López De Luchi, M.G., Rapalini, A.E., Fanning, C.M., Galindo, C. (2014), The Gondwana connections of northern Patagonia, Journal of the Geological Society, 171, 313-328.

Pereira, M.F., Castro, A., Chichorro, M., Fernández, C., Díaz-Alverado, J., Marti, J., Rodríguez, C., 2014, Chronological link between deep-seated processes in magma chambers and eruptions: Permo-Carboniferous magmatism in the core of Pangaea (Southern Pyrenees), Gondwana Research, 25, 290-308.

Retallack, G.J. and Krull, E.S., 1999, Landscape ecological shift at the Permian-Triassic boundary in Antarctica, Australian Journal of Earth Sciences, 46, 785-812.

Riley, T.R., Flowerdew, M.J., Whitehouse, M.J., 2012, U-Pb ion-microprobe zircon geochronology from the basement inliers of eastern Graham Land, Antarctic Peninsula, Journal of the Geological Society, London, 169, 381-393.

Rocha-Campos, A.C., Basei, M.A.S., Nutman, A.P., dos Santos, P.R. (2006), SHRIMP U-Pb zircon geochronological calibration of the Late Paleozoic supersequence, Paraná Basin, Brazil, V South American Symposium on Isotope Geology, Punta del Este: Short Papers, pp. 298301.

Rocha-Campos, A.C., Basei, M., Nutman, A, Kleiman, L., Varela, R., Llambia, E., Canile, F., de C.R. da Rose, O., 2011, 30 million yrs of Permian volcanism recorded in the Choiyoi igneous province: W Argentina and their source for younger ash fall deposits in the Paraná Basin: SHRIMP U-Pb zircon geochronology evidence, Gondwana Research, v. 19, 509523.

Rubidge, B.S., Hancox, P.J., Catuneanu, O., 2000, Sequence analysis of the Ecca-Beaufort contact in the southern Karoo of South Africa, South Afr. J. Geology, v. 103, p. 81-96.

Rubidge, B.S., Erwin, D.H., Ramezani, J., Bowring, S.A., de Klerk, W.J., 2013, High-precision temporal calibration of Late Permian vertebrate biostratigraphy: U-Pb zircon constraints from the Karoo Supergroup, South Africa, Geology.

Saylor, J.E., Stockli, D.F., Horton, B.K., Nie, J., Mora, A., 2012, Discriminating rapid exhumation from syndepositional volcanism using detrital zircon double dating: Implications for the tectonic history of the Eastern Cordillera, Colombia, GSA Bulletin, 124, 762-779.

Schwartz, J.J., Johnson, K., Mueller, P., Valley, J., Strickland, A., Wooden, J.L. (in press), Time scales and processes of Cordilleran batholith construction and high-Sr/Y magmatic pulses: Evidence from the Bald Mountain batholith, northeastern Oregon, Geosphere. 
Shen, S.-z and 21 others, 2011, Calibrating the end-Permian mass extinction, Science, 334, p. 1367-1372.

Sircombe, K.N. and Stern, R.A., 2002, An investigation of artificial biasing in detrital zircon U-Pb geochronology due to magnetic separation in sample preparation, Geochim. Cosmochim. Acta, 66, 2379-2397.

Smith, R.M.H., 1995, Changing fluvial environments across the Permian-Triassic boundary in the Karoo Basin, South Africa, and possible causes of tetrapod extinctions, Palaeogeography, Palaeoclimatology, Palaeoecology, v. 117, p. 81-95.

Smith, R.M.H., and Ward P.D., 2001, Pattern of vertebrate extinctions across an event bed at the Permian-Triassic boundary in the Karoo basin of South Africa, Geology, v. 29, p. 11471150.

Spalletti, L.A., Fanning, C.M., Rapela, C.W., 2008, Dating the Triassic continental rift in the southern Andres: the Potrerillos Formation, Cuyo Basin, Argentina, Geologica Acta, vol. $6(3)$, p. 267-283.

Sun, Y., Joachimski, M.M., Wignall, P.B., Yan, C., Chen, Y., Jiang, H., Wang, L., Lai, X., 2012, Lethally hot temperatures during the Early Triassic greenhouse., Science, 338, pp.366-370. doi: $10.1126 /$ science. 1224126

Surpless K.D., Graham S.A., Covault J.A., Wooden J., 2006, Does the Great Valley Group contain Jurassic strata? Reevaluation of the age and early evolution of a classic forearc basin: Geology, v. 34, p. 21-24, doi: 10.1130/G21940.1.

Tankard, A., Welsink, H., Aukes, P., Newton, R., Stettler, E., 2009, Tectonic evolution of the Cape and Karoo basins of South Africa, Marine and Petroleum Geology, 26, 1379-1412.

Veevers, J.J. (2004), Gondwanaland from 650-500 Ma assembly through 320 Ma merger in Pangae to 185-100 Ma breakup: supercontinental tectonics via stratigraphy and radiometric dating, Earth-Science Reviews, 68, 1-132.

Veevers, J.J., Cole, D.I., Cowan, E.J., 1994a, Southern Africa: Karoo basin and Cape fold belt, in Veevers, J.J., Powell, C.McA., eds., Permian-Triassic Pangean Basins and Foldbelts along the Panthalassan Margin of Gondwanaland, G.S.A. Memoir, v. 184, 223-279.

Veevers, J.J., Powell, C.McA., Collinson, J.W., López-Gamundí, O.R., 1994b, Synthesis, in Veevers, J.J., Powell, C.McA., eds., Permian-Triassic Pangean Basins and Foldbelts along 
the Panthalassan Margin of Gondwanaland, G.S.A. Memoir, v. 184, 223-279.

Vorster, C. (2013), Laser ablation ICP-MS age determination of detrital zircon populations in the Phanerozoic Cape and Lower Karoo Supergroup (South Africa) and correlatives in Argentina, Ph.D. thesis, University of Johannesburg.

Weislogel, A., Brunt, R.L, Flint, S., Fildani, A., Rothfuss, J., 2011, Constraints on deepwater sedimentation in the Karoo Basin, South Africa, from U-Pb Geochronology of ash interbeds, AAPG Search and Discovery Article \#90124.

Wild, R., Flint, S., Hodgson, D., 2009, Stratigraphic evolution of the upper slope and shelf edge in the Karoo Basin, South Africa, Basin Research, v. 21, 502-527.

Wilson, A., Flint, S., Pavenberg, T., Tohver, E., Lanci, L., 2014, Architectural styles and sedimentology of the fluvial Lower Beaufort Group, Karoo Basin, South Africa, Journal of Sedimentary Research, v. 84, 326-348.

Zeigler, A.M., Scotese, C.R., Barrett, S.F., 1983, Mesozoic and Cenozoic paleogeographic maps, in Tidal Friction and the Earth's Rotation II, eds. P. Brosche and J. Sundermann, pp 240252, Springer-Verlag: New York. 


\section{CHAPTER 2: PETROGENESIS AND PROVENANCE OF DISTAL VOLCANIC TUFFS FROM THE PERMIAN-TRIASSIC KAROO BASIN, SOUTH AFRICA: A WINDOW INTO A DISSECTED, MAGMATIC PROVINCE}

\section{ABSTRACT}

We present zircon rare-earth element (REE) compositions integrated with $\mathrm{U}-\mathrm{Pb}$ ages of zircon and whole rock geochemistry from 29 volcanic tuffs preserved in the Karoo Supergroup, South Africa, to investigate the history of magmatism in Southern Gondwana. Whole rock compositions suggest a subduction-driven, magmatic arc source for early ( $>270 \mathrm{Ma})$ to middle Permian (270-260 Ma) Karoo tuffs. After $\sim 265 \mathrm{Ma}$, the magmatic source of the volcanic deposits transitioned toward intraplate, shallow-sourced $(<40 \mathrm{~km})$ magmatism. Zircon U-Pb ages and REE chemistry suggest that early to middle Permian magmas were oxidizing, U- and HREE-enriched, melts, while middle Permian to Triassic zircon record HREE-depleted, more reduced magmatism. Middle Permian to Triassic tuffs contain increasingly large volumes of "zircon cargo" derived from assimilated crustal material; therefore magmas may have been zircon undersaturated, resulting in less zircon growth and increased inheritance in late Permian to Triassic, Gondwanan volcanics. Zircon $\mathrm{U}-\mathrm{Pb}$ ages and REE chemistry suggest a shift from arc magmatism in the early Permian to extensional magmatism by the late Permian, which may be associated with development of a backarc magmatic system adjacent to Western Antarctica that predates known extensional volcanism elsewhere in Gondwana. Opening of the Southern Ocean in the Jurassic-Cretaceous paralleled this extensional feature, which may be related to reactivation of this Permo-Triassic back arc. This study demonstrates the potential of zircon $\mathrm{U}-\mathrm{Pb}$ age and REE compositions from volcanic tuffs preserved in sedimentary strata to provide a more complete record of magmatism, when the magmatic province has been largely lost to active tectonism.

Submitted to Geosphere on 25JUN2014, as of 11SEPT2015 accepted; revisions submitted:

McKay, M.P., Coble, M.A., Hessler, A.M., Weislogel, A.L., Fildani, A., Petrogenesis and provenance of distal volcanic tuffs from the Permian-Triassic Karoo Basin, South Africa: A window into a dissected, magmatic province. 


\section{INTRODUCTION}

The magmatic history of igneous provinces is often poorly preserved in the rock record due to rifting of continental crust, orogenic uplift and erosion, and successive intrusion by younger, genetically unrelated magmas along long-lived active margins (Barth et al., 2013). Volcanic tuffs preserved in sedimentary basins, however, have been shown to contain a more complete timeseries record of volcanism (Perkins and Nash, 2002) since syn-tectonic sedimentary basins tend to subside during periods of active magmatism and deformation (DeCelles, 2012). Studies of modern volcanism, however, have shown that the composition of volcanic tuffs varies with distance from the volcanic vent during atmospheric transport (Hinkley et al., 1980; Fruchter et al., 1980; Taylor and Lichte, 1980) via crystal fractionation through settling of minerals and volcanic glass based on density out of ash clouds with increasing distance (Hinkley et al., 1980). Further convoluting the petrologic link between the distal volcanic deposits and the magmatic source, weathering and diagenetic alternation of chemically unstable glass shards can further alter tuff chemistry and mineralogy (Dahlgren et al., 1993; 1997).

Whole-rock elemental composition continues to be useful in bridging the link between distal volcanic tuffs and their parental magmas (Tomlinson et al., 2014; Heintz et al., 2015), in particular through the use of immobile trace elements (e.g., Rb, Y, Nb, $\mathrm{Zr}$, and REEs) that are less affected by weathering or diagenetic processes in volcanic ashes (Floyd and Winchester, 1978; Hastie et al., 2007). However, recent research into the partitioning of trace elements into zircon (Grimes et al., 2007; Rubatto and Hermann, 2007; Schoene et al., 2012), a highly refractory and durable mineral phase, has proven the potential of zircon chemical composition to provide insight into deep crustal magmatic processes. Laser Ablation-Inductively Coupled Plasma Mass Spectrometer (LA-ICPMS) (Li et al., 2000; Kohn and Corrie, 2011, Kylander-Clark et al., 2013) and Secondary Ion Mass Spectrometer (SIMS) analyses (McClelland et al., 2009) techniques now allow for the simultaneous microanalysis of $\mathrm{U}-\mathrm{Pb}$ isotopic and trace element compositions on single zircon crystals, leading to the development of the relatively new field of petrochronology, which couples radiometric age with trace element geochemical composition on single mineral crystals (Kylander-Clark et al., 2013). Zircon petrochronology has been employed to investigate a wide range of petrologic processes, including the time scales for pluton construction (Barboni et al., 2013; Chelle-Michou et al., 2014), crustal melting (Barth et al., 2013; Gordon et al., 2013), high-grade metamorphic processes (Rubatto, 2002; Hiess et al., 2015), volcanic tuff deposits, and tephrochronology (e.g., Schmitt et al., 2010; Harvey, 2014).

In this study we use whole rock major $\left(\mathrm{SiO}_{2}, \mathrm{TiO}_{2}, \mathrm{Al}_{2} \mathrm{O}_{3}, \mathrm{FeO}\right.$ (total), $\mathrm{MnO}, \mathrm{MgO}, \mathrm{CaO}$, $\mathrm{Na}_{2} \mathrm{O}, \mathrm{K}_{2} \mathrm{O}, \mathrm{P}_{2} \mathrm{O}_{5}$ ) and trace element (Ni, Cr, Sc, V, Ba, Rb, Sr, Zr, Y, Nb, Ga, Cu, Zn, Pb, La, Ce, 
Th, Nd, U, Cs) composition combined with single zircon U-Pb isotopic and REE compositions from distal, volcanic tuffs in the Karoo Supergroup of South Africa to investigate the magmatic provenance of volcanic tuffs in the Karoo Basin, characterize the petrogenetic history of PermianTriassic magmatism along the margin of southern Gondwana, and demonstrate the utility of petrochronology in tephra-based studies. While whole rock geochemistry of Permian Karoo tuffs are comparable to known transitional magmatism in South America, while zircon $\mathrm{U}-\mathrm{Pb}$ ages and REE compositions in Karoo tuffs record evidence of a transition from hydrous, more evolved magmatism in the early to middle Permian to drier, more primitive magmatism in the middle to late Permian. The timing of this magmatic shift and zircon geochemistry are not compatible with known South American volcanics and requires a reevaluation of the volcanic source. We explore the implications of the zircon $\mathrm{U}-\mathrm{Pb}$ and $\mathrm{REE}$ data when coupled with whole rock data from volcanic tuffs to characterize a volcanic system that has been largely lost to active tectonism.

\section{GEOLOGIC BACKGROUND}

The Carboniferous-Triassic Karoo Supergroup of South Africa preserves distal volcanic deposits that were erupted from a continental magmatic arc system along the southern margin of Gondwana (Veever et al., 1994, Bangert et al., 1999; Panhurst et al., 2006,; Fildani et al., 2007; Fig.1). Karoo Supergroup tuffs are fine-grained and grade from green, clay-rich, thin beds (typically $<10 \mathrm{~cm}$ ) in the deep-to-marginal marine Ecca Group, to brown, lithic-rich and white, chalky beds that can be up to $\sim 40 \mathrm{~cm}$ (but typically $<10 \mathrm{~cm}$ ) in the overlying terrestrial Beaufort Group (Fildani et al., 2007; McKay et al., 2015). The transition from green-clay-rich tuffs towards more chalky and lithic-rich volcanic deposits is marked by a "tuff-gap" (McKay et al., 2015) that may correlate to decreased volcanism.

Based on stratigraphic correlations, the Karoo tuffs have widely been suggested to be sourced by the same magmatic system responsible for eruption of ignimbrite sequences interbedded with clastic continental strata within the Permian Choiyoi Group and Puesto Viejo Formation in central South America (Fig. 1; Bangert et al., 1999; Cole, 1992; López-Gamundi and Rossello, 1998; Rocha-Campos et al., 2011). Choiyoi Group magmatism can be characterized as two distinct igneous suites generated during different phases of southern Gondwanan tectonic history. The early-to-middle Permian Lower Choiyoi Group (290-265 Ma) contains rocks with a volcanic arc affinity characterized by low $\mathrm{Zr}(<200 \mathrm{ppm}), \mathrm{Nb}(<15 \mathrm{ppm})$, and $\mathrm{Y}(<80 \mathrm{ppm})$ with generally higher $\mathrm{Sr} / \mathrm{Y}(>30)$ compositions and are sourced from active subduction along the southern Gondwana margin (Panhurst et al., 2006; Kleiman and Japas, 2009). In contrast, the middle-to-late Permian (265-251 Ma) Upper Choiyoi Group volcanic rocks indicate a post-orogenic magmatic source and contain elevated $\mathrm{Zr}(100-700 \mathrm{ppm}), \mathrm{Nb}(10-35 \mathrm{ppm})$, and Y (70-90 ppm), and low $\mathrm{Sr} / \mathrm{Y}(<40)$ 


\section{South America}

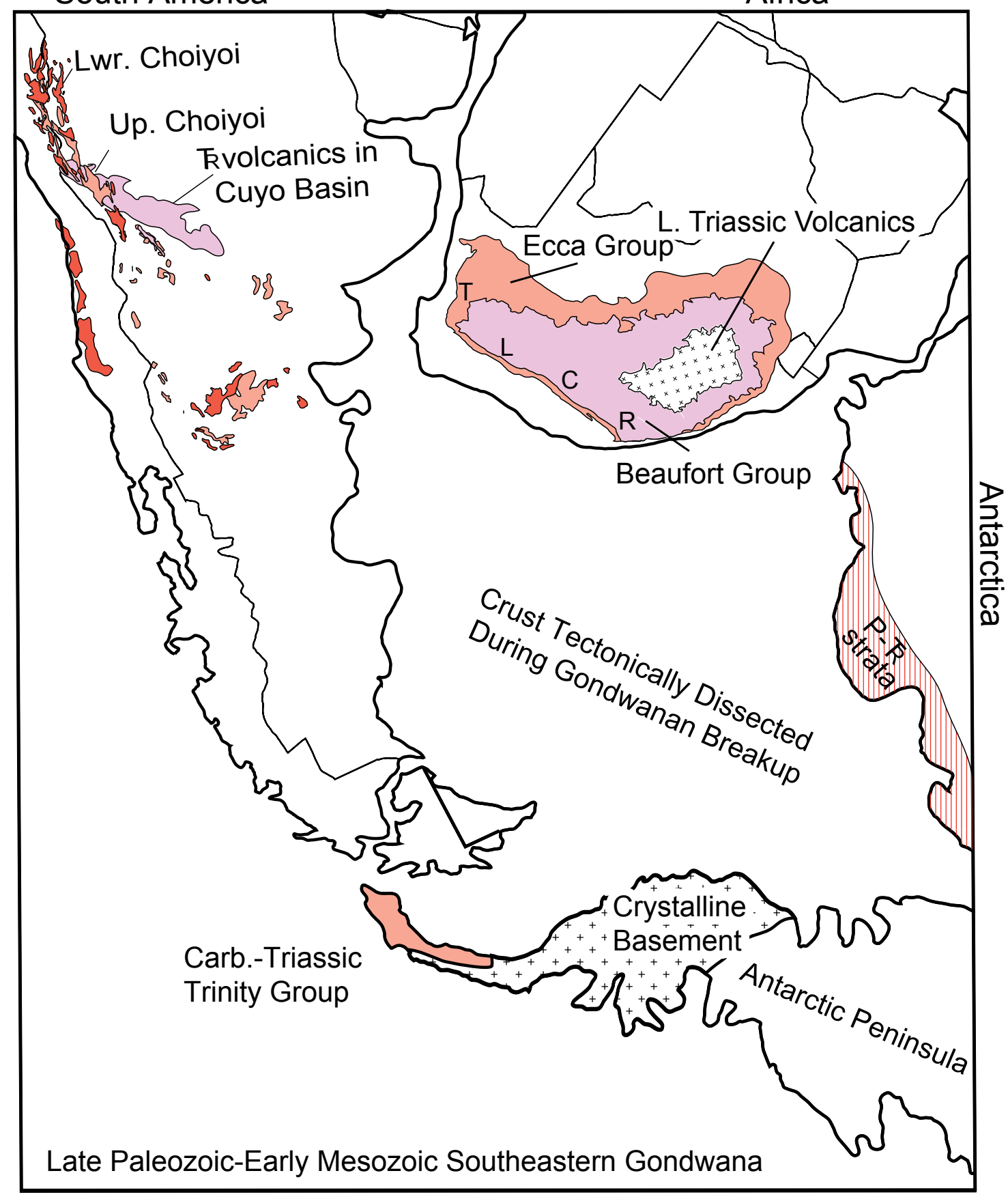

Figure 1: Simplified geologic map of southwestern Gondwana (López-Gamundi and Rossello,1998; polar projection) shows the approximate locations of the Karoo Basin, Permian-Triassic volcanic suites in South America (Choiyoi and Puesto Viejo), western Antarctic volcanogenic sediments (from Elliott et al., 2015 ${ }^{\mathrm{ab}}$ ) and Antarctic Peninsula igneous suites (Riley et al., 2008). This study looks to compare the volcanic tuffs from the Karoo to potential igneous sources in South American and Antarctica to evaluate volcanic provenance and the implications for Gondwanan tectonism. Note the large area between the African continent and the active margin that has been dissected during opening of the Atlantic and Southern Ocean. Depocenters denoted: Tanqua (T), Laingsburg (L), central (C), and Ripon (R). 
(Kleiman and Salvarredi, 2001, Kleiman and Japas, 2009). Following a period of magmatic quiescence from 251-240 Ma, the Triassic Puesto Viejo volcanic rocks (240-230 Ma) were erupted during a phase of continental extension and rifting (Ramos and Kay, 1991, Kleiman and Japas, 2009).

Some workers have questioned this historic correlation of Karoo Supergroup tuffs with South American volcanic centers due to the distance between the southern Karoo Basin and known volcanism along the Gondwanan margin, which would have been $>1000 \mathrm{~km}$ based on paleogeographic reconstructions (Bangert et al., 1999; Lanci et al., 2013). This long distance is inconsistent with the grain size of Karoo tuffs, which includes casts of pyroclastic grains, suggesting a more proximal volcanic source, possibly as close as 100-300 km from the basin (McLachlan and Jonker, 1990; Bangert et al., 1999). Further complicating correlation efforts is that eruptive age control has been difficult to obtain for the middle Permian through Middle Triassic volcanic rocks in southern Gondwana (Domeier et al., 2011; Ottone et al., 2014, McKay et al., 2015). U-Pb SHRIMP (Sensitive High Resolution Ion MicroProbe) studies of the Choiyoi and Puesto Viejo volcanics have shown that recycled/inherited zircon grains dominate Late Permian to Early Triassic tuffs, with few zircon crystallization ages interpreted to be syneruptive making interpretation of the age of eruption and deposition difficult (Spalletti et al., 2008; Rocha-Campos et al., 2006; Domeier et al., 2011). Ages for volcanic rocks in South America have been obtained through a combination of U-Pb zircon and ${ }^{40} \mathrm{Ar} /{ }^{39} \mathrm{Ar}$ ages (Spalletti et al., 2008; Rocha-Campos et al., 2006; Domeier et al., 2011, Ottone et al., 2014). Volcanic deposits from the Lower Choiyoi yield U-Pb zircon ages that range from 282-265 Ma (Rocha-Campos et al., 2011). Upper Choiyoi Group rocks yield U$\mathrm{Pb}$ zircon ages that range from 265-251 Ma (Rocha-Campos et al., 2011), that are within error of ${ }^{40} \mathrm{Ar} /{ }^{39} \mathrm{Ar}$ plateau ages of 260 (biotite) and 256 (K-spar) Ma from correlative rocks (Domeier et al., 2011). Puesto Viejo volcanic rocks display ${ }^{40} \mathrm{Ar} /{ }^{39} \mathrm{Ar}$ amphibole and potassium feldpsar ages that are younger than U-Pb zircon from the same samples (Domeier et al., 2011). While the lower Puesto Viejo Group typically yield $\sim 265 \mathrm{Ma} \mathrm{U}-\mathrm{Pb}$ zircon ages, ${ }^{40} \mathrm{Ar} /{ }^{39} \mathrm{Ar}$ plateau ages range from 235 (K-spar) to 254 (biotite) Ma, with a number of samples producing 240 Ma plateau age in amphibole and K-spar (Domeier et al., 2011). These ages are significantly younger than $\mathrm{U}-\mathrm{Pb}$ zircon ages from the Puesto Viejo Group, suggesting zircon crystallization predates eruption and cooling by $>10 \mathrm{Ma}$.

Similarly, zircon U-Pb geochronology of Karoo Supergroup tuffs also reveal a scarcity of zircon with syneruptive ages in Permo-Triassic volcanic deposits (McKay et al., 2015). This lack of syneruptive zircon has led to a number of contradictory age results for the Karoo Supergroup (Fildani et al., 2007; 2009; Lanci et al., 2013; Rubidge et al., 2013; McKay et al., 2015). The age "paradox" resolved in South American volcanic suites (Domeier et al., 2011; Ottone et al., 
2014) is likely linked to long-term magmatic zircon recycling (Domeier et al., 2011; Ottone et al., 2014; McKay et al., 2015) and similar zircon recycling may be the cause of the age controversy in the Karoo Supergroup strata (McKay et al., 2015). Based on U-Pb zircon age populations and stratigraphic position, tuffs in the Ecca Group are coeval with the Upper Choiyoi Group volcanic rocks (265-250 Ma), while tuffs in the Beaufort Group correlate to the Triassic ( $<240 \mathrm{Ma})$ Puesto Viejo Group. This correlation, however, is based entirely on geochronology, and no geochemical evidence has been presented to link the South African and South American volcanic deposits.

Closer candidates for volcanic sources have not been identified, primarily because large portions of the crust where a more proximal volcanic source may have existed has since been tectonically destroyed or buried through rifting and opening of the Atlantic and Indian Oceans. Portions of Antarctica, the Antarctic Peninsula, and other terranes (i.e. Thurston Island and Mary Byrd Land) are thought to have been adjacent to these now missing crustal blocks (Lawver et al., 1992), and could also have hosted the volcanic system that sourced Karoo tuffs. The Antarctic terranes record Cambrian through Jurassic magmatism and metamorphism (Millar et al., 2002). Permian-Triassic granitoids are located in crystalline basement terranes (Riley et al., 2012), and possibly correlative tuffs are present in Permian-Triassic strata in Antarctic sedimentary basins (Elliot et al., 2015 ). Therefore, the Karoo tuffs may have been sourced by more proximal volcanic systems located in the dissected Gondwanan crust adjacent to Antarctic terranes.

\section{WHOLE ROCK GEOCHEMISTRY}

\section{Methods}

Whole rock geochemistry from 41 volcanic tuff samples (Fig. 2) from the Karoo Basin were determined by $\mathrm{x}$-ray fluorescence (XRF) and inductively coupled mass spectrometry (ICPMS) at the Washington State University's GeoAnalytical Lab. Major element oxide $\left(\mathrm{SiO}_{2}, \mathrm{TiO}_{2}, \mathrm{Al}_{2} \mathrm{O}_{3}\right.$, $\mathrm{FeO}$ (total), $\mathrm{MnO}, \mathrm{MgO}, \mathrm{CaO}, \mathrm{Na}_{2} \mathrm{O}, \mathrm{K}_{2} \mathrm{O}, \mathrm{P}_{2} \mathrm{O}_{5}$ ) and trace element compositions ( $\mathrm{Ni}, \mathrm{Cr}, \mathrm{Sc}, \mathrm{V}$, $\mathrm{Ba}, \mathrm{Rb}, \mathrm{Sr}, \mathrm{Zr}, \mathrm{Y}, \mathrm{Nb}, \mathrm{Ga}, \mathrm{Cu}, \mathrm{Zn}, \mathrm{Pb}, \mathrm{La}, \mathrm{Ce}$, Th, Nd, U, Cs), along with volatile content (loss on ignition [LOI]) were collected using XRF methods described by Johnson et al. (1999). For ICPMS analyses, samples were analyzed for trace and rare earth element concentrations (La, $\mathrm{Ce}, \mathrm{Pr}, \mathrm{Nd}$, Sm, Eu, Gd, Tb, Dy, Ho, Er, Tm, Yb, Lu, Ba, Th, Nb, Y, Hf, Ta, U, Pb, Rb, Cs, Sr, Sc, Zr), as described by Lichte et al. (1987), Jarvis (1988), Jenner et al. (1990), and Longerich et al. (1990). Elemental concentrations were collected by both XRF and ICPMS for Sc, Ba, Rb, Sr, Zr, Y, Nb, La, $\mathrm{Ce}, \mathrm{Th}, \mathrm{Nd}, \mathrm{U}, \mathrm{Cs}$, with $90 \%$ XRF measured concentrations are within $\pm 10 \%$ of the ICPMS results ( $\sim 70 \%$ of XRF results are within $\pm 5 \%$ of ICPMS values), suggesting good agreement between both analytical techniques. Four samples were analyzed 2-3 times to assess instrumental drift and reproducibility; multiple analyses showed no significant instrumental bias or analytical variability. 


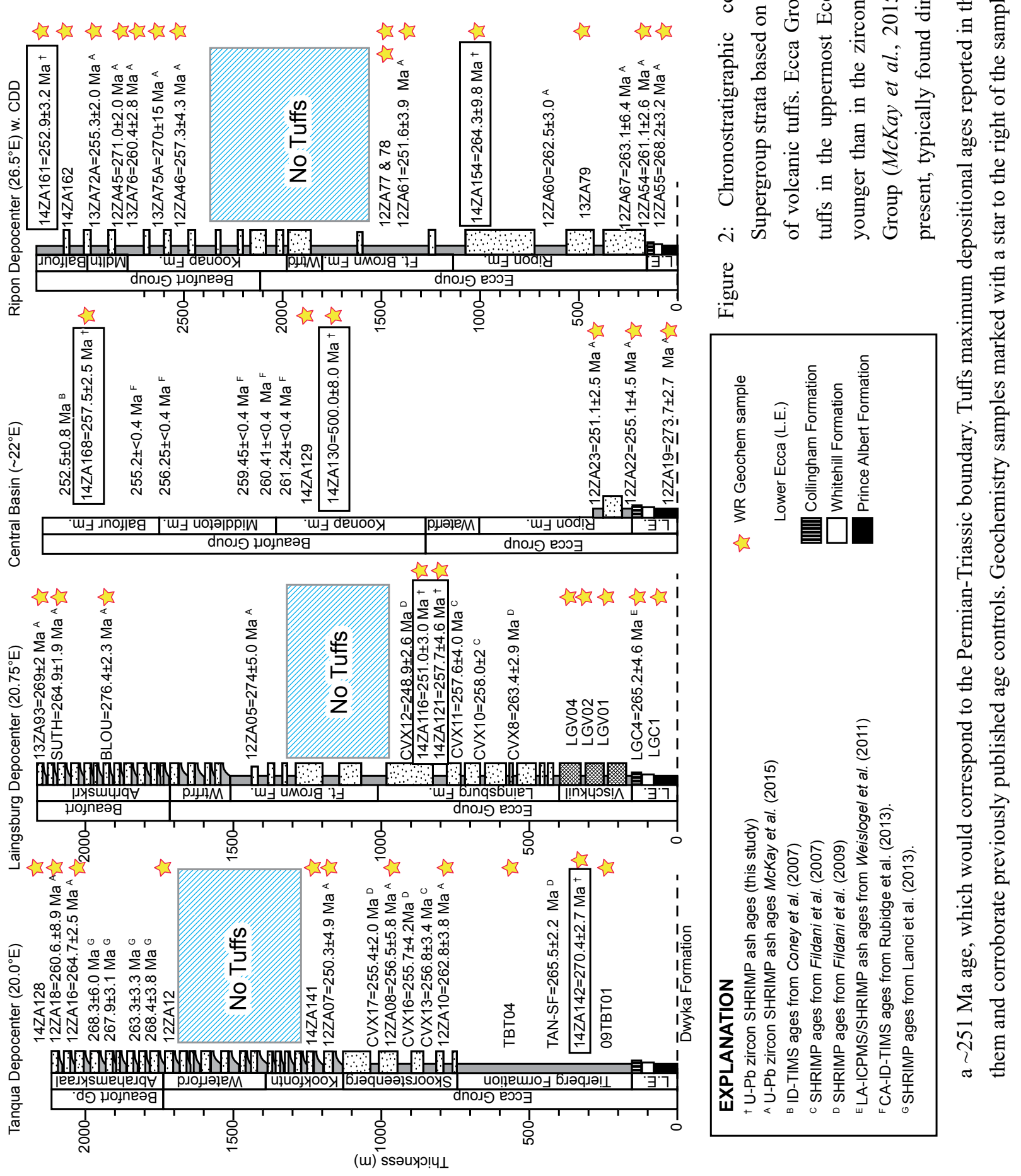




\section{Results}

Major element concentrations for 41 volcanic tuffs (Appendix C) show variability in $\mathrm{SiO}_{2}$, $\mathrm{Al}_{2} \mathrm{O}_{3}$, and $\mathrm{CaO}$. Six samples with high $\mathrm{CaO}$ (>5\% weight), low $\mathrm{SiO}_{2}(<50 \%)$, high $\mathrm{LOI}(>10 \%)$ are likely to contain minor secondary calcite and are excluded from further discussion (09TBT01, SUTHER, 12ZA61, 14ZA121, 14ZA128, 14ZA129) since their composition may have been affected by secondary diagenetic alteration. The remaining analyses $(\mathrm{N}=35)$ were normalized to oxide totals (LOI excluded). Samples containing no significant calcite have $\mathrm{SiO}_{2}$ that range from 47 to $73 \%, \mathrm{Al}_{2} \mathrm{O}_{3}$ between 12 and $30 \%, \mathrm{CaO}<5 \%, \mathrm{NaO}<5 \%, \mathrm{~K}_{2} \mathrm{O}$ from 1 to $7 \%$, and $\mathrm{P}_{2} \mathrm{O}_{5}$ typically $<1 \%$. FeO values are reported as total $\mathrm{Fe}$ and range between 1 and $7 \%$. MnO content is less than $0.3 \%$ and $\mathrm{MgO}$ varies slightly between 0.5 and 2.5 , with most values between 1 and $2 \%$. $\mathrm{TiO}_{2}$ is between 0.2 and $0.9 \%$ for all samples. Little variation is observed between the geochemistry of samples from the Beaufort and Ecca Groups in major element geochemistry. Trace elements results, including REEs, (Fig. 3A-H) also shows no distinguishing characteristics between the Ecca and Beaufort Group tuffs. Ecca Group tuffs show more compositional variability than the overlying Beaufort Group tuffs in $\mathrm{Nb}$ (ppm), Zr (ppm), Y (ppm), and Rb (ppm), Yb (ppm), and Ce (ppm). Both the Ecca and Beaufort tuffs have negative sloped REE patterns with minor negative $\mathrm{Eu}$ anomalies. The most prominent $\mathrm{Eu}$ anomalies are two positive Eu anomalies, both found in Ecca tuffs. Five Beaufort tuffs also contain negative Ce anomalies and 1 Beaufort tuff contained a positive Ce anomaly, while no Ce anomalies were observed in Ecca tuffs.

\section{ZIRCON U-Pb AGES AND REE COMPOSITION}

\section{Methods}

Twenty-nine tuffs were sampled from 4 transects through formations of the Ecca and Beaufort Groups exposed along the southern Karoo Basin (Fig. 1). Zircon grains were separated from samples using mineral separation techniques, including the use of a Franz magnetic separator to remove magnetically susceptible zircon that may have high $U$ and yield discordant results (Sircombe and Stern, 2002). Zircon yields were variable for different sample; ranging between 0 and $>200$ zircon. Size, morphology, and inclusion density were not considered when selecting zircon for analysis in an effort to characterize the entire zircon population of a tuff and not bias results towards prismatic, acicular, euhedral zircon populations. Zircon grains were mounted in epoxy and polished to expose an interior cross-section of the grain. Catholuminescence images were used to avoid inclusions and complex cores, and to target intermediate grey (corresponding to $U$ concentration between 100-1000 ppm), oscillatory-zoned, rim domains near for in-situ zircon analyses. In-situ zircon analyses were performed on the SHRIMP-RG (sensitive high resolution ion microprobe - reverse geometry) ion microprobe at the Stanford University Microscopic Analytical 

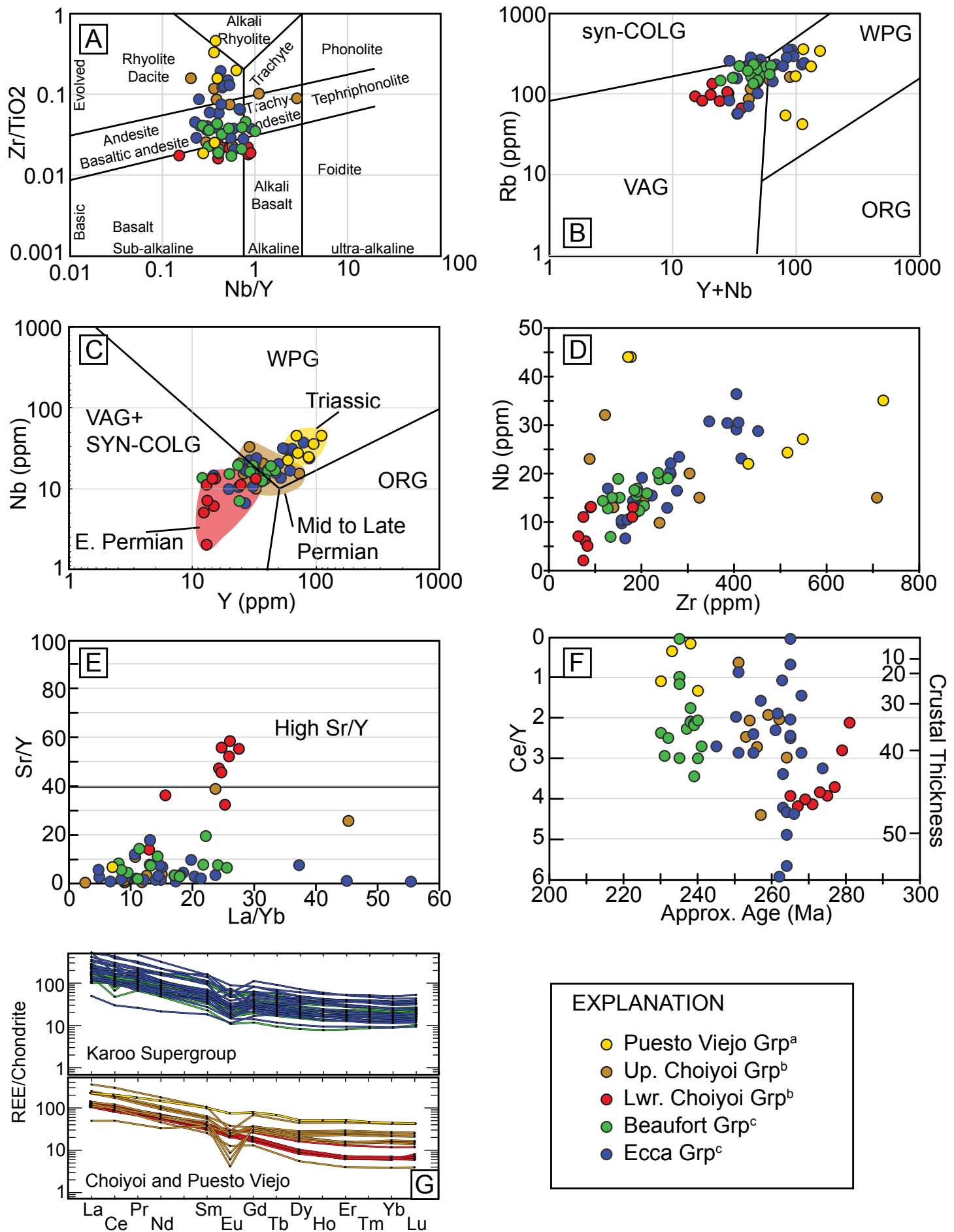

Figure 3: Whole rock geochemistry of Karoo tuffs plotted with geochemistry from the Choiyoi Group (Kleiman and Salvarredi, 2001; Kleiman and Japas, 2009) and Puesto Viejo (Kleiman and Salvarredi, 2001) volcanic deposits in South America. (A) $\mathrm{Zr} / \mathrm{TiO} 2$ vs. $\mathrm{Nb} / \mathrm{Y}$ with geochemical discrimination diagram of Winchester and Floyd (1977), (B) Rb vs. Y+Nb, (C) Nb vs. Y with discrimination diagram of Pearce et al. (1984) COLGcollisional granitoid; WPG-within plate granitoid; VAG-volcanic arc granitoid; ORG-orogenic granitoid, (D) $\mathrm{Nb}$ vs. Zr, (E) Sr/Y vs. La/Yb, (F) Ce/Y vs. Approx. age (Ma), (G) chondrite normalized REE spider diagrams. 
Center (SUMAC) under analytical conditions similar to those of Barth and Wooden (2010). The primary ion beam $\left(\mathrm{O}_{2}^{-}\right)$was focused to a spot diameter between 18 to 22 microns in diameter, a depth of $\sim 1.5$ microns for analyses performed in this study. $\mathrm{U}-\mathrm{Pb}$ ages were calculated with reference to the R33 and Temora zircon standards (419.3 and 416.8 Ma; Black et al., 2004). Zircon trace elements, including U, La, Ce, Nd, Sm, Eu, Gd, Tb, Dy, Er, Yb, Lu, Hf, Th, and U were measured concurrently with $\mathrm{U}-\mathrm{Pb}$ analyses and calibrated with the compositional zircon standard MADDER (Barth and Wooden, 2010). Model ages and trace element concentrations were calculated using the SQUID 2.51 (Ludwig, 2009) and ISOPLOT 3.76 software (Ludwig (2012). ${ }^{206} \mathrm{~Pb} /{ }^{238} \mathrm{U}$ ages are corrected for common $\mathrm{Pb}$ using ${ }^{207} \mathrm{~Pb}$ (assuming ${ }^{206} \mathrm{~Pb} /{ }^{238} \mathrm{U}-{ }^{207} \mathrm{~Pb} /{ }^{235} \mathrm{U}$ age-concordance) and a model $\mathrm{Pb}$ composition from Stacey and Kramers (1975) with no additional error propagated from the uncertainty in the model common- $\mathrm{Pb}$ composition. On average, zircon analyses contained $>99.5 \%$ radiogenic $\mathrm{Pb}$ and the common- $\mathrm{Pb}$ correction was negligible for accepted analyses.

Of the 590 total individual grain analyses, 520 were accepted ranging from 226 to $2607 \mathrm{Ma}$ on the basis of low common- $\mathrm{Pb}$ concentrations, low analytical uncertainty $(<3 \%)$ and concordance. Grains were determined to be concordant if ${ }^{238} \mathrm{U} /{ }^{206} \mathrm{~Pb}$ and ${ }^{207} \mathrm{~Pb} /{ }^{206} \mathrm{~Pb}$ ages overlapped within $2 \sigma$ uncertainty. To determine maximum depositional ages, anomalously old zircon ages ( $>300 \mathrm{Ma})$ are interpreted as inherited, xenocrystic or detrital in origin, while anomalously young $(<<\sim 250$ $\mathrm{Ma})$, high-U (>1000 ppm) or high common- $\mathrm{Pb}$ are dismissed as having been affected by $\mathrm{Pb}-$ loss or common- $\mathrm{Pb}$ contamination (resulting in an anomalous common $\mathrm{Pb}$ correction). Zircon age populations that were identified using kernel density estimate (KDE) plots to interpret the youngest, coherent population within a tuff. A weighted mean age was calculated from the youngest, coherent population of concordant grains ( $>3$ grains) to determine maximum depositional ages for 6 of 7 tuffs. One, zircon-poor tuff contained only anomalously old, Cambrian or older age grains, with no coherent population. Uncertainties for weighted mean ages are presented as $2 \sigma$, including internal and external error. We report REE compositions for the $469 \mathrm{U}-\mathrm{Pb}$ zircon ages from 22 volcanic tuffs reported by McKay et al. (2015) and an additional $121 \mathrm{U}-\mathrm{Pb}$ zircon ages and REE compositions from 7 new tuff samples (Appendix D). There is no geographic relationship observed in $\mathrm{U}-\mathrm{Pb}$ ages or REE zircon compositions. Zircon $\mathrm{U}-\mathrm{Pb}$ ages, however, do show stratigraphic trends, and, therefore, samples will be presented based on stratigraphic position.

\section{$U-P b$ zircon maximum depositional ages}

The 121 newly obtained $\mathrm{U}-\mathrm{Pb}$ zircon ages provide estimates for the maximum depositional age of 7 volcanic tuffs from the Karoo Basin are reported based on stratigraphic order: 1 sample from the southwestern Karoo near Robertson, Western Cape, 2 tuffs from the Laingsburg depocenter in the western Karoo Basin, 2 tuffs from the Central Karoo Basin, and 2 tuffs from the Ripon depocenter in the eastern Karoo Basin (UTM locations in Electronic Appendix). 


\section{ECCA GROUP}

Four tuff samples were collected form within the Ecca Group: 1 from the Tanqua depocenter, 2 from Laingsburg depocenter, and 1 from Ripon depocenter (Fig. 2). Sample, 14ZA142, was collected from the lower Ecca Group within a structural inlier of Karoo Supergroup strata correlated with the Tanqua depocenter within the Cape fold belt near Robertson, Western Cape. The two youngest individual zircon ages are $226 \pm 6$ and $256 \pm 9 \mathrm{Ma}$, but were rejected on the basis of relatively high analytical uncertainties $(\sim 3 \%, 1 \sigma)$ and do not define a population. Therefore, the youngest, coherent population yields an age of $270.4 \pm 2.7(2 \sigma, n=5, M S W D=2.1)$. Sample 14ZA154 was collected from a clay-rich tuff in the middle Ripon Formation of the Ecca Group near Grahamstown, Eastern Cape and contained zircon ranging in age from 230-1596 Ma. The weighted mean age of the youngest coherent zircon population is $264.3 \pm 9.8(\mathrm{n}=5, \mathrm{MSWD}=3.5)$. Sample 14ZA121 was collected from a green, clay-rich tuff near Laingsburg, Western Cape from the middle-to-upper Laingsburg Formation and contained zircon that ranged in age between 220$1036 \mathrm{Ma}$. A subpopulation of 6 grains yielded a weighted mean age of $257.7 \pm 4.6 \mathrm{Ma}$, with an MSWD of 3.7. Zircon from 14ZA116, sampled from a clay-rich tuff in the upper Laingsburg Formation, ranged in age from 228-1888 Ma. From 40 total analyses, 31 were Permian-Triassic in age. A population of 10 grains yield a weighted mean age of $250.0 \pm 2.1$ Ma with an MSWD=3.7. Ages from samples 14ZA121 and 14ZA116 strongly suggest a late Permian to Early Triassic maximum depositional age for the upper Laingsburg.

\section{BEAUFORT GROUP}

Three samples were collected from the Beaufort Group. Sample 14ZA130 was collected from a light-brown tuff in the upper Abrahamskraal/Koonap Formation within the Beaufort Group (Fig. 2) about $25 \mathrm{~km} \mathrm{SE}$ of Fraserburg, in the central part of the basin. This tuff yielded only 8 zircon, none of which were Permian-Triassic in age. The youngest grain within 14ZA130 was Late Cambrian with age of $497 \pm 6 \mathrm{Ma}(1 \sigma)$, which is an age that has been reported for Permian-Triassic tuffs in the Karoo Supergroup (McKay et al., 2015) as well as in coeval volcanics in South America (Domeier et al., 2011). Sample 14ZA168, collected 10 miles north of Graaff-Reinet, Eastern Cape, in the middle Balfour Formation within the central basin yielded zircon that ranged in age between 252 and 1620 Ma. Permian grains dominate this sample ( $n=19$ of 30; 63\%). A coherent population of 11 grains produce a weighted mean age of $257.5 \pm 2.5 \mathrm{Ma}(\mathrm{MSWD}=1.43)$, which serves as the maximum deposition age for the Balfour Formation. Sample 14ZA161 was collected $\sim 10 \mathrm{~km} \mathrm{NE}$ of Seymour, Eastern Cape from the Balfour Formation of the Beaufort Group and contained zircon ranging in age from 219 to $2655 \mathrm{Ma}$. A small population of 5 low common $\mathrm{Pb}$, concordant zircon produce a weighted mean age of $255.4 \pm 3.1 \mathrm{Ma}$ with an MSWD $=1.8$. 


\section{Trace elements in zircon}

To understand Permian-Triassic magmatism, we focus on the geochemical composition of 364 zircon that produced $\mathrm{U}-\mathrm{Pb}$ ages $<300 \mathrm{Ma}$. Zircon data are subdivided into four age groups: early Permian (300-270 Ma), middle Permian (270-260 Ma), late Permian (260-251 Ma), and Triassic (<251 Ma) (Fig. 4). Mean $\mathrm{Hf}_{\text {zircon }}$ concentration decreases from $\sim 9300 \mathrm{ppm}$ in the early Permian to $7000 \mathrm{ppm}$ in the Early Triassic (Fig. 4A). Mean chondrite normalized $\mathrm{Yb} / \mathrm{La}_{\text {zircon }}$ decreases (Fig. 4B) from 13,200 in the early Permian to 4700 in the late Permian and $\sim 3400$ in the Early Triassic. Mean Ce/Ce* ${ }_{\text {zircon }}$ also systematically decreases (Fig. 4C) from 67 in the early Permian, to 48 in the middle Permian, to 43 in the late Permian, and finally to 12 in the Early Triassic. Mean $\mathrm{Hf} / \mathrm{Lu}_{\text {zircon }}$ decreases from 160 in the early Permian to 110 in the middle and late Permian, to 44 in the Early Triassic. Chondrite normalized Eu/Eu* ${ }_{\text {zircon }}$ (Fig. 4E) does not vary significantly through time, with early, middle, late Permian and Early Triassic grains producing mean values of $\sim 0.37$. $\mathrm{Th} / \mathrm{U}_{\text {zircon }}$ increases slightly through time from 0.64 in the early Permian to 0.77 in the late Permian (Fig. 4G). The Ecca and Beaufort Group tuffs contain elevated Th/U $(>1.0)$ zircon (Fig. 5). Beaufort Group tuffs, however, contain a larger population of higher $\mathrm{Th} / \mathrm{U}$ ( $>1.5$ ) zircon, while few Ecca Group tuff zircon exceed $\mathrm{Th} / \mathrm{U} \geq 1.5$ (Fig 5?).

\section{Ti in zircon}

The incorporation of Ti into zircon has been shown to be controlled by the temperature during crystallization (Watson and Harrison, 2005; Watson et al., 2006; Hiess et al., 2008). Concentrations of $\mathrm{Ti}$ in zircon were collected for 77 zircons from 6 tuffs (12ZA07, 12ZA22, 12ZA23, 12ZA46, 12ZA54, 12ZA61; Appendix E) concurrent with U-Pb and REE analyses. Twenty-six zircon analyses yielded high Fe concentrations ( $>300 \mathrm{ppm})$ were excluded, leaving 51 Permo-Triassic $\mathrm{Ti}_{\text {zircon }}$ analyses. $\mathrm{Ti}_{\text {zircon }}$ model temperatures were calculated based on $\mathrm{Si}$ and $\mathrm{Ti}$ activities from Claiborne et al. (2010) and range from $\sim 620^{\circ} \mathrm{C}$ to greater than $800^{\circ} \mathrm{C}$, with $\pm \sim 10 \%$ uncertainty in each analysis. As a whole, the variability observed in $\mathrm{Ti}_{\text {zircon }}$ model temperatures is minor throughout the Permian and Early Triassic, and all the Permian to Triassic average model temperatures are within uncertainty of one another (Fig. $4 \mathrm{I})$. $\mathrm{Ti}_{\text {zircon }}$ indicates temperatures $\sim 800^{\circ} \mathrm{C}$ for 285-276 Ma zircon. Temperatures decreases to below $800^{\circ} \mathrm{C}$ into the middle Permian, when $\mathrm{Ti}_{\text {zircon }}$ model temperatures indicate an average of $747 \pm 43^{\circ} \mathrm{C}(1 \sigma)$. Late Permian $\mathrm{Ti}_{\text {zircon }}$ model temperatures are slightly higher with an average $757 \pm 37^{\circ} \mathrm{C}(1 \sigma)$. Only 5 measurements were made on Early Triassic zircon and these temperature estimates are approximately equivalent with Late Permian temperature estimates, with an average $\mathrm{Ti}_{\text {zircon }}$ temperature $760 \pm 19^{\circ} \mathrm{C}(1 \sigma)$. 

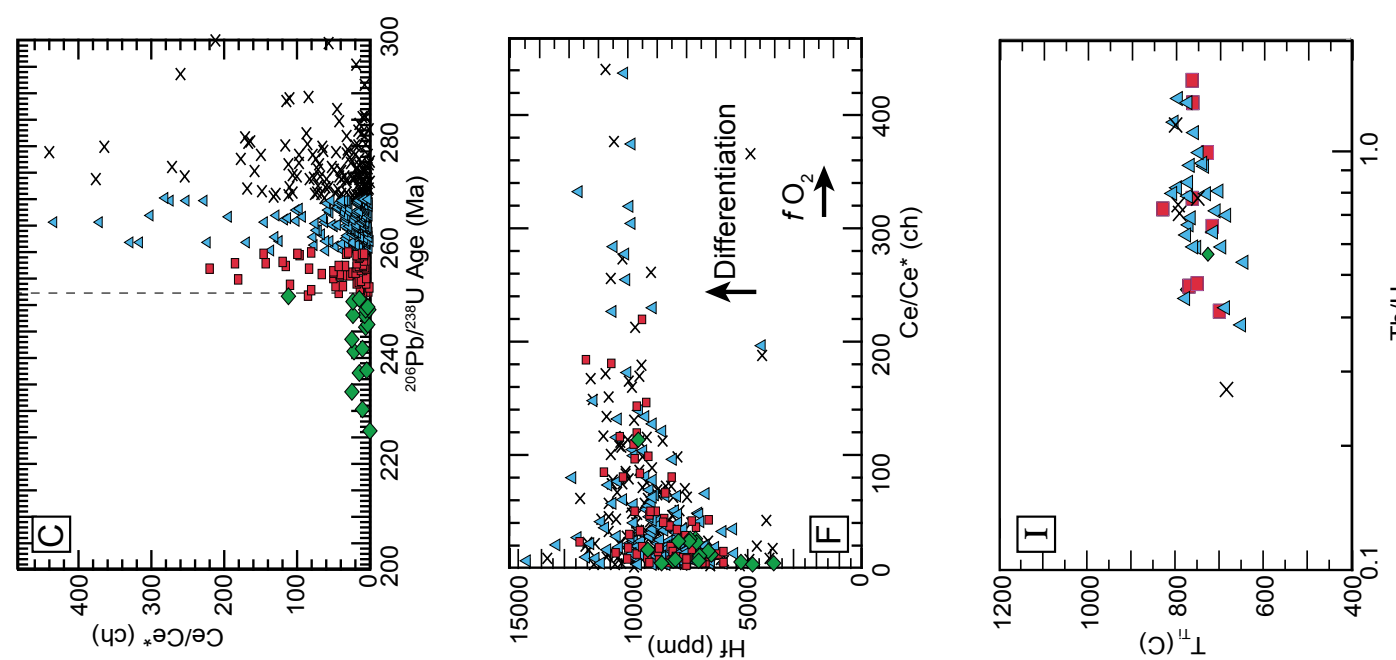

言 :

荘告

ङ

过出

올 司

总产

点

월 술

뇔

寻五?

ठิ 仓
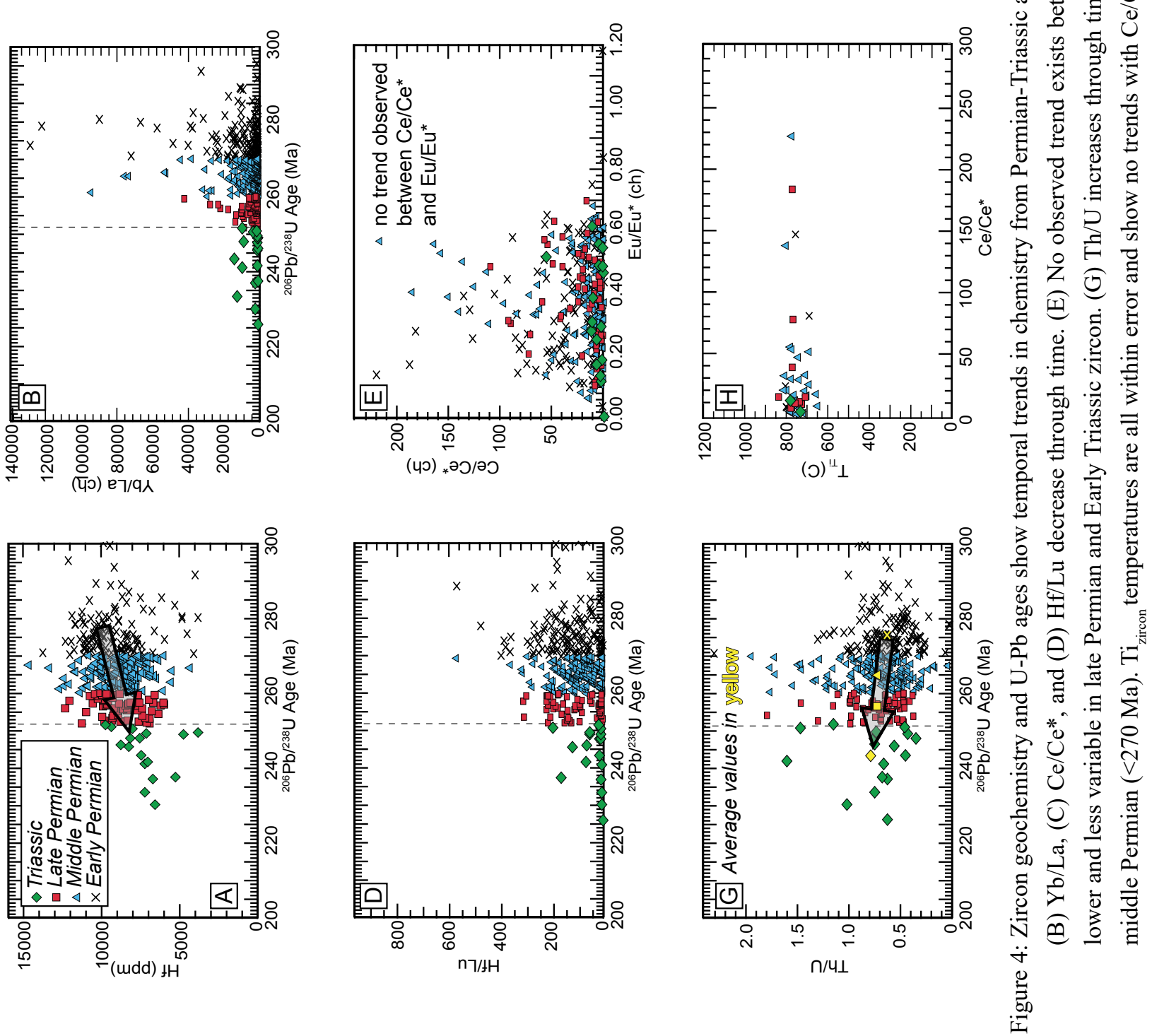


\section{DISCUSSION}

Zircon geochemistry can record the prolonged petrogenetic history of a magmatic system (Claiborne et al., 2010; Schoene et al., 2012) that may differ from the whole rock chemistry of volcanic tuffs, which is susceptible to post-eruptive alteration by hydrothermal fluids, diagenesis, and weathering processes (Hastie et al., 2007; Gatti et al., 2014), whereas zircon may preserve a more robust record of magmatic composition. Therefore, whole rock and zircon geochemistry will be discussed separately.

Petrogenesis of Karoo tuffs from whole rock geochemistry

A traditional technique to determine the tectonic source of igneous rocks is by using geochemical discrimination diagrams, in which igneous suites from well characterized tectonic settings are used to defined geochemical "fields". These fields commonly overlap and the results can be ambiguous or misleading in complex magmatic systems (Förster et al., 1997); however, since this approach has been used to classify volcanic igneous suites in age equivalent rocks from elsewhere in Gondwana (Kleiman and Japas, 2009), we compare Karoo Supergroup tuff whole rock geochemical composition with granitoid discrimination diagrams from Pearce et al. (1984) to attempt to distinguish the nature of the magmatic system that sourced the distal ashes of the Karoo Basin. Tuffs from the Ecca and Beaufort Groups in the Karoo Supergroup are nearly indistinguishable from one another based on whole rock geochemical signatures. Since major element composition may be easily altered (Hastie et al., 2007), immobile trace elements may better reflect the tectonic affinity of the tuff (Floyd and Winchester, 1978). Using a discrimination diagram based on $\mathrm{Zr} / \mathrm{TiO}_{2}$ (Fig. 3A; Winchester and Floyd, 1977) the Ecca tuffs ranged between dacitic and basaltic compositions, whereas Beaufort tuffs are basaltic to andesitic in composition. Low $\mathrm{Nb} / \mathrm{Y}(<1)$ may reflect sub-alkaline compositions for both Ecca and Beaufort tuffs. Beaufort Group tuffs show less geochemical variability in $\mathrm{Nb}, \mathrm{Zr}$, Y,and Rb compared to Ecca Group tuffs, but tuffs from both Ecca and Beaufort Groups plot between Volcanic Arc (VAG) and intraplate (Within Plate Granites-WPG) granitoid fields of Pearce et al. (1984) (Fig. 3B, 3C). This is distinct from the arc driven magmatism of the Lower Choiyoi Group in South America (Kleiman and Japas, 2009), which have lower Nb, Zr, Rb, and Y concentrations that plot (Fig. 3B, C) in the Volcanic Arc and syn-collisional granitoid fields of Pearce et al. (1984).

Karoo tuffs generally are characterized by low $\mathrm{Sr} / \mathrm{Y}(<20), \mathrm{La} / \mathrm{Yb}(<25)$, and $\mathrm{Ce} / \mathrm{Y}(<4)$ values. Based on similar $\mathrm{Nb}(>10 \mathrm{ppm}), \mathrm{Zr}(>100 \mathrm{ppm}), \mathrm{Rb}(>100 \mathrm{ppm}), \mathrm{Y}(>60), \mathrm{Sr} / \mathrm{Y}(<25)$, $\mathrm{La} / \mathrm{Yb}(<25)$, and $\mathrm{Ce} / \mathrm{Y}(<4)$ values, Karoo Supergroup tuffs are most similar to Upper Choiyoi volcanics, which are interpreted to be produced by post-orogenic collapse magmatism (Kleiman and Japas, 2009). Karoo Supergroup tuffs, similar to Upper Choiyoi and Puesto Viejo volcanics, 
contain low $\mathrm{Sr} / \mathrm{Y}(<40)$ (Fig. 3E), which indicates sourcing by primitive melt that evolved in the absence of garnet, suggesting shallow, low-pressure magmatic sources (Moyen, 2009). Ce/Y serves as proxy for the ratio of light rare earth elements (LREE) to heavy rare earth elements (HREE) (Mantle and Collins, 2008), which can be controlled by the depth of crustal melting. The majority of Karoo tuffs, like the Upper Choiyoi, and Puesto Viejo volcanics have lower Ce/Y $(<3.5)$. Several early Permian (>260 Ma) tuffs from the Ecca Group have elevated Ce/Y ( $>3.5)$, which is similar to early Permian Lower Choiyoi volcanism (Fig. 3F). The transition from high $\mathrm{Sr} / \mathrm{Y}(>40)$, high $\mathrm{Ce} / \mathrm{Y}(>3.5)$ magmatism in the early Permian to lower $\mathrm{Sr} / \mathrm{Y}(<20)$, lower $\mathrm{Ce} / \mathrm{Y}$ $(<3.5)$ magmatism observed in later Permian-Triassic Karoo, Upper Choiyoi, and Puesto Viejo volcanic suites could suggest that primitive melt sources that fed Permian-Triassic volcanism in western Gondwana were sourced increasingly shallower depths beneath possibly thinner crust. The observed transition from high $\mathrm{Sr} / \mathrm{Y}$, high $\mathrm{Ce} / \mathrm{Y}$ melts in the early Permian to lower $\mathrm{Sr} / \mathrm{Y}, \mathrm{Ce} / \mathrm{Y}$ melts in the middle Permian through Early Triassic in South American igneous suites coincides with an interpreted shift from arc to extensional magmatism (Kleiman and Japas, 2009). Although no high $\mathrm{Sr} / \mathrm{Y}$ tuffs were identified in the Karoo Supergroup, both Karoo tuffs and Choiyoi volcanics show a similar transition from high $\mathrm{Ce} / \mathrm{Y}$ melts in the early Permian (Ecca Group) to low $\mathrm{Ce} / \mathrm{Y}$ in the late Permian (Ecca) and Early Triassic (Beaufort) Karoo Supergroup.

Negative Eu anomalies in Upper Choiyoi and negative and positive Eu anomalies in Karoo tuffs (Fig. 3G) suggest the presence of plagioclase in a crustal melt source (Gao and Wedepohl, 1995). This geochemical shift might represent an increasingly shallower melt source for the Karoo tuffs, similar to the transition from deep-sourced, arc driven melting towards extensional magmatism that has been interpreted for South American volcanics. Although the similarity between South American and Karoo Supergroup tuffs could be used to support a similar parent volcanic center, a major shift to extensional magmatism likely occurred along the entire southern Gondwanan margin. Geochemistry from Permian-Triassic basalts in southeastern Gondwana has suggested coeval, Permian-Triassic crustal thinning associated with a shift towards extensional magmatism (Mantle and Collins, 2008). Therefore, a transition from subduction-driven arc magmatism towards extensional magmatism is not distinctive in identifying a specific volcanic center as the source of Permo-Triassic volcanic suites throughout southern Gondwana, but rather a transition from convergent towards extensional magmatism may have been margin-wide.

\section{Zircon petrochronology of Karoo tuffs}

Zircon trace element chemistry has been widely applied to characterize magma-chamber processes because zircon chemistry reflects the equilibrium melt composition from which it crystallized (e.g., Barth and Wooden et al., 2010; Claiborne et al., 2010). Since zircon is much 
more resistant to weathering, reworking/detrital mixing, and post-depositional alteration than other mineral phases in a tuff, it may retain the most accurate information about the magmatic source composition of a tuff. Thus, zircon geochemistry from the Permian-Triassic tuffs in the Karoo Supergroup provides an opportunity to explore the temporal history of magmatism in southern Gondwana.

The decreasing Hf concentration in zircon $\left(\mathrm{Hf}_{\text {zircon }}\right)$ from an average of $\sim 9300 \mathrm{ppm}$ in the early Permian to $\sim 7000 \mathrm{ppm}$ in the Triassic suggests melts became increasingly primitive and less fractionated through time (Fig. 4A). The decrease in $\mathrm{Ce} / \mathrm{Ce}^{*}$ from an average of 67 in the early Permian to an average of 12 in the Triassic (Fig. 4C), with no clear major change in $\mathrm{Ti}_{\text {zircon }}$ model temperatures (Fig. 4I) suggests a decrease in $\mathrm{fO}_{2}$ to more reducing magma conditions. This may represent a transition from subduction-driven arc magmatism to extensional back-arc (e.g., intraplate) magmatism, since intraplate melts are more reduced than arc magmas (e.g., Kelley and Cottrell, 2009). Hf concentration and $\mathrm{Ce} / \mathrm{Ce}^{*}$, proxies for melt evolution and $\mathrm{fO}_{2}$ respectively, generally show a direct relationship (Fig. 4F), with lowest values reflecting chemically primitive melts present in the youngest Triassic zircon. Average $\mathrm{Th} / \mathrm{U}$ in zircon increases from $\sim 0.6$ in the early Permian to 0.8 in the middle Permian through the Early Triassic, with an increasing number of high $\mathrm{Th} / \mathrm{U}(>1.0)<\sim 275 \mathrm{Ma}$ grains. With little change in $\mathrm{Ti}_{\text {zircon }}$ model temperatures, this suggests that middle-to-late Permian melts became less evolved, indicating derivation from a more mafic source (Kirkland et al., 2015).

\section{Zr saturation and inheritance}

More primitive, less evolved melts tend to have lower Si activity (i.e., quartz not present as a crystallizing phase) and generally have lower $\mathrm{Zr}$ concentration, as $\mathrm{Zr}$ is an incompatible trace element which generally increases with increasing melt evolution or differentiation. A shift towards more primitive melts (i.e., lower whole rock $\mathrm{Zr}$, increase in $\mathrm{Th} / \mathrm{U}_{\text {zircon }}$, and decreasing $\mathrm{Hf}$ and $\mathrm{Ce} / \mathrm{Ce}$ * in zircon) may explain the high occurrence of recycled zircon (i.e., zircon older than $260 \mathrm{Ma}$ ) in Beaufort tuffs compared to the underlying Ecca tuffs. Ecca tuffs display a wide range of whole rock Zr concentrations (129-453 ppm, mean: $292 \mathrm{ppm}$ ) that are on average higher than in the overlying Beaufort tuffs (118-258 ppm; mean=205 ppm). Lower Zr abundance would lead to melts that are less likely to achieve $\mathrm{Zr}$ saturation, resulting in decreasing zircon crystallization. $\mathrm{Ti}_{\text {zircon }}$ model temperature suggest that zircon from Karoo tuffs crystalized in melts between $\sim 700$ $800^{\circ} \mathrm{C}$, a temperature range where inheritance-rich magmas are common (Miller et al., 2003). The Zr saturation models of Watson and Harrison (1983) estimate that the minimum whole-rock concentration of $\mathrm{Zr}$ required to crystallize zircon in a sub-alkaline basaltic andesite is $\sim 115 \mathrm{ppm}$ at $\sim 750^{\circ} \mathrm{C}$ and $\sim 225 \mathrm{ppm}$ at $800^{\circ} \mathrm{C}$. Ecca Group tuffs contain a wide range of $\mathrm{Zr}$, with a low $\mathrm{Zr}$ 
population ranging from 130-347 $\mathrm{ppm}$ and a higher $\mathrm{Zr}$ population with concentrations between $\mathrm{Zr}$ 400-500 ppm. The bimodal nature of whole rock Zr concentrations (Fig. 3D) in Ecca tuffs suggest that while some Permian magmatism may have been Zr-poor, periodic, high Zr magmatism may have driven zircon crystallization during Ecca time. Zr whole-rock composition of Beaufort tuffs (118-257 ppm) are all near the lower limit for zircon saturation concentrations at $700-800^{\circ} \mathrm{C}$ with no evidence for episodic high $\mathrm{Zr}$ magmatism, which suggest that little to no new zircon would crystallize in the magmatic source of the tuffs deposited in the Beaufort Group, particularly within melts above $>750^{\circ} \mathrm{C}$. New zircon growth may have been restricted (or absent altogether) during Beaufort-age magmatism, which would promote the occurrence of inherited grains in volcanic tuffs, as has been observed in Beaufort tuffs (McKay et al., 2015). Increased inheritance of zircon would also account for the difficulty in obtaining reliable $\mathrm{U}-\mathrm{Pb}$ zircon depositional age constraints in Beaufort tuffs.

\section{Zircon correlation between South Africa and Gondwanan suites}

Zircon REE data is not available in the published literature for potential correlative magmatic and volcanic suites from South American and Antarctica, therefore, correlations based on zircon chemistry are restricted to $\mathrm{Th}$ and $\mathrm{U}$, since these elements are collected for all $\mathrm{U}-\mathrm{Pb}$ zircon analyses. Since magmatic temperature, composition, and fractionation control $\mathrm{Th} / \mathrm{U}$ in zircon $(\mathrm{Th} /$ $\mathrm{U}_{\text {zircon}}$; Kirkland et al., 2015), volcanic deposits that share a magmatic source should contain zircon that display comparable $\mathrm{Th} / \mathrm{U}_{\text {zircon }}$ trends with time (i.e. ${ }^{238} \mathrm{U} /{ }^{206} \mathrm{~Pb}$ age). In Karoo tuffs, $\mathrm{Th} / \mathrm{U}_{\text {zircon }}$ evolved from exclusively low $\mathrm{Th} / \mathrm{U}(<1.0)$ in the early Permian $(300-270 \mathrm{Ma})$ to highly variable $\mathrm{Th} / \mathrm{U}$ that range from $>1.5$ to 0.2 from the middle Permian to Triassic $(<270 \mathrm{Ma})$. $\mathrm{Th} / \mathrm{U}_{\text {ziron }}$ from South America volcanic suites (Spalletti et al., 2008; Rocha-Campos et al., 2011; Domeier et al., 2011; Barredo et al., 2012; Ottone et al., 2014) increases from low variability, dominantly low $\mathrm{Th} /$ $\mathrm{U}_{\text {zircon }}(<1.0)$ in the Permian to high variability, high $\mathrm{Th} / \mathrm{U}_{\text {zircon }}(>1.0)$ during Triassic rifting (Fig. 5). High $\mathrm{Th} / \mathrm{U}_{\text {zircon }}(>1)$ may occur in zircon that crystallized from less evolved melts (Kirkland et al., 2015), and the occurrence of a wide range of $\mathrm{Th} / \mathrm{U}_{\text {zircon }}$ compositions likely represents spatially and/or temporally dynamic variable magmatic source chemistry or temperatures (Barth et al., 2013; Kirkland et al., 2015).

Zircon from Karoo tuffs that contain high $\mathrm{Th} / \mathrm{U}_{\text {zircon }}(>1.0)$ range in age from $280-240$ $\mathrm{Ma}(\mathrm{n}=45$ of $364 ; \sim 12 \%)$. This contrasts with $\mathrm{Th} / \mathrm{U}_{\text {zircon }}$ from South American volcanic rocks, where high $\mathrm{Th} / \mathrm{U}_{\text {zircon }}(>1.0)$ is mostly restricted to Triassic $(<245 \mathrm{Ma})$ grains $(\mathrm{n}=17$ of 186; $\sim 9 \%$ ) that are associated with Puesto Viejo and Rincón rift volcanic rocks. Puesto Viejo volcanism also recycled older Permian [280-250 Ma] Choiyoi-age zircon "cargo" (Fig. 5A) resulting in a bimodal population of older, low $\mathrm{Th} / \mathrm{U}_{\text {zircon }}$ zircon between $0.3-0.5$ and younger, high $\mathrm{Th} / \mathrm{U}_{\text {zircon }}$ 

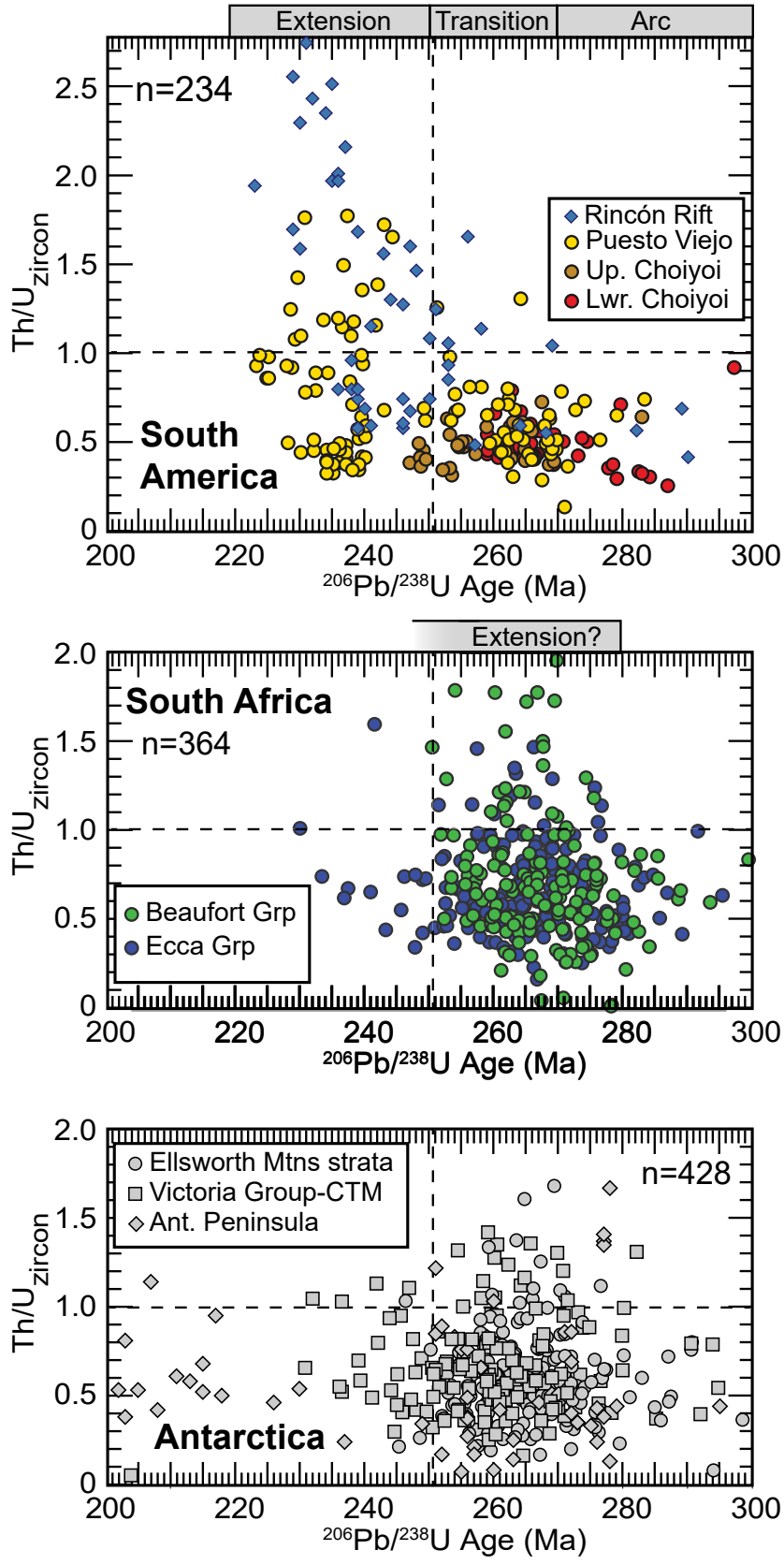

Figure 5: Th/U vs U-Pb age (Ma) for Permian-Triassic zircon from (A) South America (Spalletti et al., 2008; Rocha-Campos et al., 2011; Domeier et al., 2011; Barredo et al., 2012; Ottone et al., 2014), (B) Karoo Supergroup-South Africa (this study), and (C) Antarctica (Riley et al., 2012; Elliot et al., in press'; Elliot et al., in press $^{\mathrm{b}}$ ). (A) High $\mathrm{Th} / \mathrm{U}$ zircon (>1.0) in South America are related to Puesto Viejo and Rincón rift volcanism between $<245$ Ma. (B) Karoo tuffs also contain high $\mathrm{Th} / \mathrm{U}$ zircon, but high $\mathrm{Th} / \mathrm{U}_{\text {zircon }}$ are significantly older (275-255 Ma) than those in South America. (C) Antarctic volcanogenic sediments also contain high Th/U Permian zircon suggesting a correlation between Karoo tuffs and volcanism adjacent to Antarctica. The presence of higher $(>1.0)$ zircons, which are present in extensional magmatism in South America, might reflect an early phase of extensional magmatism near Antarctica.

zircon between 0.8-2.5. Similar high ( $>1.0)$ $\mathrm{Th} / \mathrm{U}_{\text {zircon }}$ is observed in 280-250 Ma zircon recovered from Beaufort and Ecca Group tuffs (Fig. 5B), which is not compatible with it being sourced from South America, where 280-250 Ma zircon are almost entirely devoid of high $\mathrm{Th} / \mathrm{U}_{\text {zircon }}(>1.0)$. We, therefore, propose that high $\mathrm{Th} / \mathrm{U}_{\text {zircon }}(>1.0)$ might record 270-250 Ma extensional magmatism elsewhere in Gondwana that is either not yet identified or is buried in the subsurface.

Permian zircon with high $\mathrm{Th} / \mathrm{U}_{\text {zircon }}$ are, however, present in volcaniclastic suites from Antarctica (Fig. 5C) are geochemically and temporally compatible with sharing a magmatic source with Karoo Supergroup tuffs. Mid-crustal plutons in the Antarctic peninsula (Riley et al., 2012) and volcaniclastic strata in the Central Transantarctic (Elliot et al., in press ${ }^{\mathrm{a}}$ ) and Ellsworth 
Mountains (Elliot et al., in press ${ }^{b}$ ) contain zircon with variable $\mathrm{Th} / \mathrm{U}_{\text {zircon }}$ ranging from $<0.01$ to 1.7. High $\mathrm{Th} / \mathrm{U}$, Permian-Triassic zircon ( $>1.0)$ from Antarctica comprise a similar proportion of the Permian-Triassic zircon population ( $\mathrm{n}=41$ of $428 ; \sim 10 \%$ ) with most high $\mathrm{Th} / \mathrm{U}_{\text {zircon }}(>1$ ) occurring between 280-250 Ma, similar to Karoo tuff zircon. Based on this comparison, midcrustal and volcanogenic sediment/tuffs from Antarctica most closely match the U-Pb age and $\mathrm{Th} / \mathrm{U}$ composition of zircon in the Karoo Basin, suggesting that volcanic tuffs were sourced from Antarctica or elsewhere in Gondwana. Therefore, although the whole rock geochemistry of South American and Karoo Supergroup volcanic suites are comparable, the $\mathrm{Th} / \mathrm{U}_{\text {zircon }}$ of coeval zircon composition is not.

\section{Implications for Gondwanan tectonism}

The geochemistry of volcanic tuffs from the Karoo Supergroup suggests that the magmatic source for Karoo ashes was not a subduction-driven, continental volcanic arc sourced from beneath the middle to lower crust $(>40 \mathrm{~km})$. In contrast, geochemistry suggests that the tuffs were sourced from a system transitioning towards intraplate volcanism which is characterized by high $\mathrm{Nb}, \mathrm{Zr}, \mathrm{Y}$, and lower $\mathrm{Sr} / \mathrm{Y}, \mathrm{La} / \mathrm{Yb}$, and $\mathrm{Ce} / \mathrm{Y}$. Intraplate, post-orogenic to rift related magmatism like began by $\sim 270 \mathrm{Ma}$ within southwestern Gondwana, $\sim 30 \mathrm{Ma}$ earlier than previously thought. Tuff whole-rock geochemistry records low $\mathrm{Sr} / \mathrm{Y}(<20)$ and $\mathrm{Ce} / \mathrm{Y}$ (decreasing from up to 5 in the middle Permian to $<3$ in the late Permian to Early Triassic), which suggests a lack of garnet and melts less enriched in LREE, respectively. This interpretation suggests a shallowing origin of melt (Fig. 4G, H) that is geochemically compatible with back-arc extensional volcanism (Fig. 4E). Zircon geochemistry further corroborates this hypothesis, with decreasing Hf (ppm) (Fig. 4A) suggesting more primitive, lower $\mathrm{fO}_{2}$, less-hydrous melts (Fig. 4C), which would be expected during a transition from convergent arc to extensional magmatism. High $\mathrm{Th} / \mathrm{U}_{\text {zircon }}$ in Permian zircon may share a similar genetic history to Triassic rift-related zircon in the Puesto Viejo volcanics of South America, but temporally predate Puesto Viejo magmatism. Therefore, a poorly understood backarc magmatic zone may rest in the basement rocks of the extended, buried margins of the South American, Antarctic, or African continental shelf. Recent research in the Antarctic has inferred back-arc extension between the Antarctic Peninsula and other, outboard fragmented terranes of southern Gondwana and east Antarctica (Fig. 6; Elliot et al., in press ${ }^{\mathrm{b}}$ ). Elliot et al. (in press $^{b}$ ) suggested the presence of Permo-Triassic back-arc basins along the boundaries between 1.) the Antarctic Peninsula and South Africa/Eastern Antarctica and 2) Mary Byrd Land and Eastern Antarctica. The geochemical and geochronological data presented here supports the presence of this hypothetical back-arc magmatism in western Gondwana, although little, direct physical evidence of this system remains exposed, nor has it been identified in the subsurface through borehole or geophysical data. Extensional magmatism in the Permian Antarctic-Karoo back- 


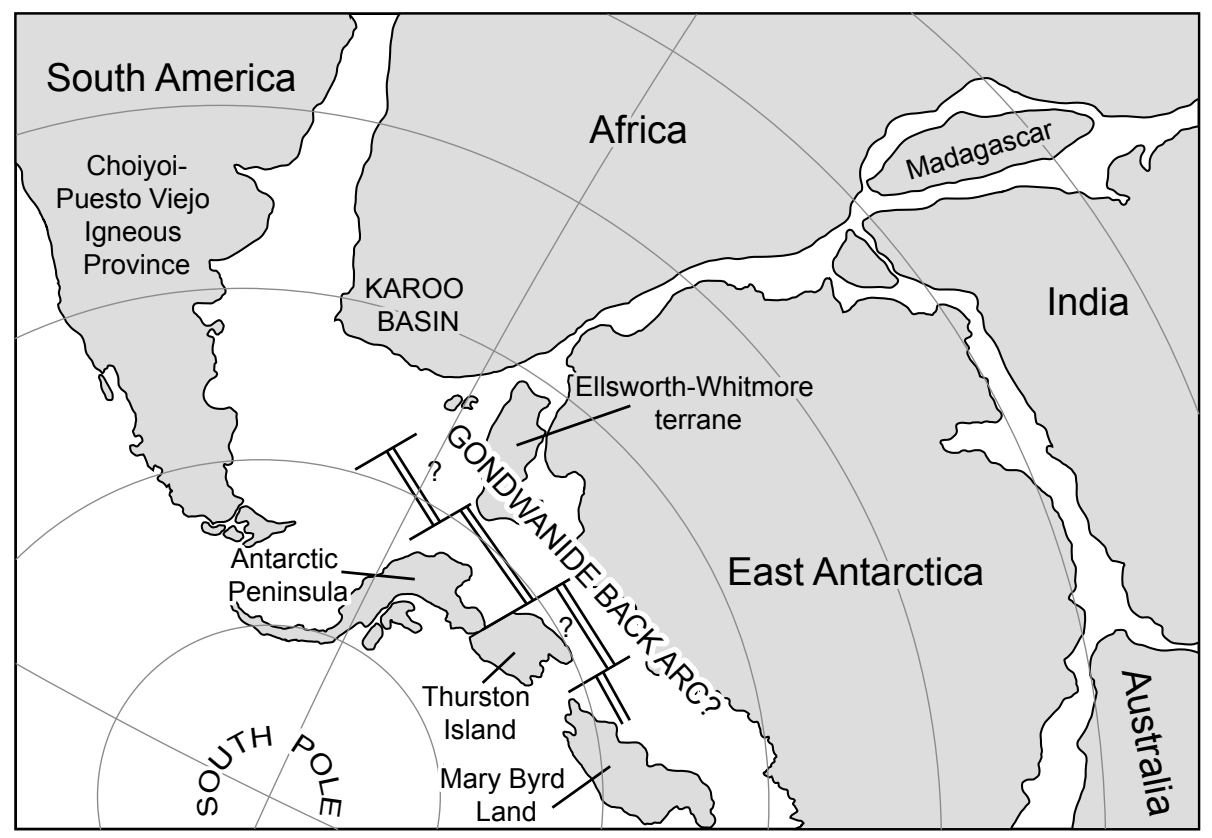

Figure 6: Paleogeographic schematic map of southern Gondwana with the location of possible back arc magmatism (Elliot et al., 2015 ) inboard of the Gondwanide magmatic arc.

arc appears to predate Triassic extensional magmatism in South America, indicating PermianTriassic rifting may have migrated westward over time. The development of a Permian-Triassic age crustal weakness in the now-dissected crust of Gondwana may have ultimately played a role in the subsequent Jurassic rifting and break-up of the Gondwanan supercontinent along those pre-existing crustal boundaries. The break-up of Gondwana is typically considered to have begun along the boundary between Africa and Antarctica, just to the east of the Karoo Basin. The Karoo Igneous Province, located in the central Karoo Basin (Fig. 1) may be related to initial rifting of Gondwana (Encarnación et al., 1996; Jourdan et al., 2005). Jurassic rifting of western Gondwana would parallel the trend of the Permian-Triassic extensional feature with the southern Atlantic and Southern oceans opening along the same crustal boundary in a similar southeast to northwest trend. The hypothesized Permian-Triassic back-arc was located at the triple junction along which South America, Africa, and Antarctica rift apart, which suggests this missing tectonic feature may have played a pivotal role in Mesozoic rifting of Gondwana and morphology the tectonic plates generated from the break-up of Gondwana.

\section{CONCLUSIONS}

Based on tuff whole rock and zircon geochemistry and $\mathrm{U}-\mathrm{Pb}$ geochronology, we propose that volcanic tuffs in the Karoo Basin may have been sourced by a post-orogenic to rift extensional magmatic system. Although Karoo tuffs have been linked to age-correlative South American 
volcanism, zircon REE and $\mathrm{Th} / \mathrm{U}$ geochemistry suggests that Karoo tuffs are genetically more similar to volcanic tuffs and volcanogenic sediment in Antarctica. Zircon geochemistry suggests that volcanism was sourced from increasingly reduced, primitive magmas in the middle to late Permian, while whole rock geochemistry shallower-sourced melts in an intraplate setting. We interpret these observations to be consistent with back arc magmatism. With the intense tectonic dissection of southern Gondwana during Mesozoic opening of the Indian and Atlantic oceans, large portions of the Gondwanan rock record are not accessible for field study and high detail geochemical-geochronology analyses, and no evidence for this possible back arc remains. Integrating $\mathrm{U}-\mathrm{Pb}$ zircon and zircon $\mathrm{REE}$ geochemistry with whole rock tuff geochemistry allows us to reconstruct the magmatic history of Gondwana and missing tectonographic provinces. This study demonstrates the utility of zircon $\mathrm{U}-\mathrm{Pb}$ and $\mathrm{REE}$ analyses for $\mathrm{U}-\mathrm{Pb}$ zircon provenance of volcanic tuffs to provide insight beyond whole rock chemistry, which may be altered by posteruptive processes. Currently, the global lack of zircon geochemistry datasets hinders wide-spread use of integrated zircon $\mathrm{U}-\mathrm{Pb}$ and geochemistry as a correlation tool. Advances in microanalysis in the near future may facilitate a proliferation of zircon geochemistry, greatly enhancing provenance techniques in sedimentology, petrology, and tephrochronology.

\section{ACKNOWLEDGMENTS}

This work was partially funded by grants from the American Association of Petroleum Geologist, Society for Sedimentary Geology, and Geological Society of America to McKay, West Virginia University to McKay and Weislogel, and a cooperative agreement between West Virginia University, the University of Manchester, and University of Leeds through the SLOPE4 consortium.

\section{REFERENCES}

Bangert, B., Stollhofen, H., Lorenz, V., Armstrong, R. (1999), The geochronology and significance of ash-fall tuffs in the glaciogenic Carboniferous-Permian Dwyka Group of Namibia and South Africa, Journal of African Earth Sciences, vol. 29 (1), p. 33-49.

Barboni, M., Schoene, B., Ovtcharova, M., Bussy, F., Schaltegger, U., Gerdes, A. (2013), Timing of incremental pluton construction and magmatic activity in a back-arc setting revealed by ID-TIMS U/Pb and Hf isotopes on complex zircon grains, Chemical Geology, v. 340, 7693, doi: 10.1016/j.chemgeo.2012.12.011.

Barredo, S., Chemale, F., Marsicano, C., Ávila, J.N., Ottone, E.G., Ramos, V.A. (2012), Tectonosequence stratigraphy and $\mathrm{U}-\mathrm{Pb}$ zircon ages of the Rincón Blanco Depocenter, northern 
Cuyo Rift, Argentina, Gondwana Research, vol. 21, p. 624-636.

Barth, A.P. \& Wooden J.L. (2010), Coupled elemental and isotopic analyses of polygenetic zircons from granitic rocks by ion microprobe, with implications for melt evolution and the sources of granitic magmas. Chemical Geology 277: 149-159. doi:10.1016/j.chemgeo.2010.07.017.

Barth, A.P., Wooden, J.L., Jacobson, C.E., Economos, R.C. (2013), Detrital zircon as a proxy for tracking the magmatic arc system: The California arc example, Geology, 41 (2), 223-226, doi: $10.1130 / \mathrm{G} 33619.1$.

Black, L.P., Kamo, S.L., Allen, C.M., Davis, D.W., Aleinikoff, J.N., Valley, J.W., Mundil, R., Campbell, I.H., Korsch, R.J., Williams, I.S., and Foudoulis, C., 2004, Improved 206Pb/238U microprobe geochronology by the monitoring of a trace-element-related matrix effect; SHRIMP, ID-TIMS, ELA-ICP-MS and oxygen isotope documentation for a series of zircon standards, Chemical Geology, v. 205, p. 115-140.

Chelle-Michou, C., Chiaradia, M., Ovtcharova, M., Ulianov, A., Wotzlaw, J. (2014), Zircon petrochronology reveals the temporal link between potphyry systems and the magmatic evolution of their hidden plutonic roots (the Eocene Coroccohuayco deposit, Peru), Lithos, vol. 198-199, p. 129-140, doi:10.1016/j.lithos.2014.03.017

Claiborne, L.L., Miller, C.F., Flanagan, D.M., Clynne, M.A., Wooden, J.L. (2010), Zircon reveals protracted magma storage and recycling beneath Mount St. Helens, Geology, vol. 38 (11), p. 1011-1014.

Cole, D.I. (1992), Evolution and development of the Karoo basin, in de Wit, M.J. \& Ransome, I.G.D. (Eds), Inversion tectonics of the Cape fold belt, Karoo and Cretaceous basins of southern Africa, Balkema: Rotterdam, 87-100.

Dahlgren, R., Shoji, S., Nanzyo, M. (1993), Mineralogical characteristics of volcanic ash soils, in: Shoji, S., Dahlgren, R., Nanzyo, M. (eds), Volcanic Ash Soils, Genesis, Properties, and Utilization: Developments in Soil Science. Elsevier: Amsterdam.

Dahlgren, R., Dragoo, J., Ugolini, F. (1997), Weathering of Mt. St. Helens Tephra under a cryicudic climate regime, Soil Sci. Soc. Am. J., 61, 1519-1525.

DeCelles, P.G. (2012), Foreland basin systems revisited: variations in response to tectonic settings, in Tectonics of Sedimentary Basins: Recent Advances, eds. C. Busby and A.A. Pérez, Wiley-Blackwell Publishing: New York.

Domeier, M., Van der Voo, R., Tomezzoli, R.N., Tohver, E., Hendriks, B.W.H., Torsvik, T.H., Vizan, H., Dominguez, A. (2011), Support for an "A-type" Pangea reconstruction from high-fidelity Late Permian and Early to Middle Triassic paleomagnetic data from Argentina, 
Journal of Geophysical Research, vol. 116, B12114, 26 p., doi:10.1029/2011JB008495

Elliot, D.H., and Fanning, C.M. (2008), Detrital zircons from upper Permian and lower Triassic Victoria Group sandstones, Shackleton Glacier region, Antarctica: Evidence for multiple sources along the Gondwana plate margin, Gondwana Research, vol 13, 259-274.

Elliot, D.H., Fanning, C.M., Hulett, S.R.W. (2015) ${ }^{\mathrm{a}}$, Age provinces in the Antarctic craton: Evidence from detrital zircons in Permian strata from the Beardmore Glacier region, Antarctica, Gondwana Research, vol X, p. X-X, doi:10.1016/j.gr.2014.03.013.

Elliot, D.H., Fanning, C.M., Laudon, T.S. $(2015)^{\mathrm{b}}$, The Gondwana Plate margin in the Weddel Sea sector: zircon geochronology of Upper Paleozoic (mainly Permian) strata from the Ellsworth Mountains and eastern Ellsworth Land, Antarctic, Gondwana Research, doi:10.1016/j.gr.2014.12.001.

Encararnación, J., Fleming, T.H., Elliot, D.H., Eales, H.V. (1996), Synchronous emplacement of Ferrar and Karoo dolerites and the early breakup of Gondwana, Geology, v. 24, p. 535-538.

Fildani, A., Drinkwater, N.J., Weislogel, A., McHargue, T., Hodgson, D.M., Flint, S.S. (2007), Age controls on the Tanqua and Laingsburg deep-water systems: New insights on the evolution and sedimentary fill of the Karoo Basin, South Africa, J. Sediment. Res., v. 77, p. 901-908.

Fildani, A., Weislogel, A., Drinkwater, N.J., McHargue, T., Tankard, A., Wooden, J., Hodgson, D., Flint, S. (2009), U-Pb zircon ages from the southwestern Karoo Basin, South AfricaImplications for the Permian-Triassic boundary, Geology, v. 37, p. 719-722.

Floyd, P.A. and Winchester, J.A. (1978), Identification and discrimination of altered and metamorphosed volcanic rocks using immobile elements, Chemical Geology, vol. 21 (34), p[. 291-306.

Förster, H.J., Tischendorf, G., Trumbull, R.B. (1997), An evaluation of the Rb vs ( $\mathrm{Y}+\mathrm{Nb})$ discrimination diagram to infer tectonic setting of silicic igneous rocks, Lithos, vol 40 (24), p. 261-293.

Fruchter, J.S., Robertson, D.E., Evans, J.C., 19 others (1980), Mount St. Helens ash from the 18 May 1980 eruption: chemical, physical, mineralogical, and biological properties, Science, 209 (5), 1116-1125.

Gao, S. and Wedepohl, K. H. (1995), The negative Eu anomaly in Archean sedimentary rocks: implications for decomposition, age and importance of their granitic sources, Earth Planet. Sci. Lett., vol. 133, 81-94.

Gatti, E., Villa, I.M., Achyuthan, H., Gibbard, P.L., Oppenheimer, C. (2014), Geochemical 
variability in distal and proximal glass from the Youngest Toba Tuff eruption, Bull. Volcanol., 76:859, 16 p.

Grimes, C.B., John, B.E., Kelemen, P.B., Mazdab, F.K., Wooden, J.L., Cheadle, M.J., Hanghoj, K., Schwartz, J.J. (2007), Trace element chemistry of zircons from oceanic crust: A method for distinguishing detrital zircon provenance, Geology, vol. 35 (7), p. 643-646.

Gordon, S.M., Whitney, D.L., Teyssier, C., Fossen, H. (2013), U-Pb dates and trace-element geochemistry of zircon from migmatite, Western Gneiss Region, Norway: significance for history of partial melting in continental subduction, Lithos, 170-171, 35-53.

Hastie, A.R., Kerr, A.C., Pearce, J.A., Mitchell, S.F. (2007), Classification of altered volcanic island arc rocks using immobile trace elements: development of the $\mathrm{Th} / \mathrm{Co}$ discrimination diagram, Journal of Petrology, 48 (12), 2341-2357.

Harvey, J.C. (2014), Zircon age and oxygen isotopic correlations between Bouse Formation tephra and the Lawlor Tuff, Geosphere, 10 (2), 221-232.

Heintz, M.L., Yancey, T.E., Miller, B.V., Heizler, M.T. (2015), Tephrochronology and geochemistry of Eocene and Oligocene volcanic ashes of east and central Texas, Geological Society of America Bulletin, 127, p. 770-780.

Hiess, J., Nutman, A.P., Bennett, V.C., Holden, P. (2008), Ti-in-zircon thermometry applied to contrasting Archean metamorphic and igneous systems, Chemical Geology, 247, 323-338. doi:10.1016/j.chemgeo.2007.10.012.

Hiess, J., Yi, K., Woodhead, J., Ireland, T., Rattenbury (2015), Gondwana margin evolution from zircon REE, O and Hf signatures of Western Province gneisses, Zealandia, Geological Society, London, Special Publications, 389 (1), 323-353.

Hinkley, T.K., Smith, K.S., Taggart, J.E., Jr., Brown, J.T. (1980), Chemical and mineralogical aspects of the observed fractionation of ash from the May 18, 1980 eruption of Mount St. Helens, U.S. Geological Survey Professional Paper 1397-A.

Jarvis, K.E. (1988), Inductively coupled plasma mass spectrometry; a new technique for the rapid or ultra-trace level determination of the rare-earth elements in geological materials. Chemical Geology, 68, 31-39.

Jenner G.A., Longerich H.P., Jackson S.E., and Fryer B.J. (1990), ICP-MS - A powerful tool for high-precision trace-element analysis in Earth sciences: Evidence from analysis of selected U.S.G.S. reference samples. Chemical Geology, 83, 133-148.

Johnson, D.M., Hooper, P.R., Conrey, R.M. (1999), XRF analysis of rocks and minerals for major 
and trace elements on a single low dilution Li-tetraborate fused bead, Advances in X-ray Analysis, 41, 843-867.

Johnston, S.T. (2000), The Cape Fold Belt and Syntaxis and the rotated Falkland Islands: dextral transpressional tectonics along the southwest margin of Gondwana, Journal of African Earth Sciences, 31 (1), 51-63. doi: 10.1016/S0899-5362(00)00072-5.

Jourdan, F., Féraud, G., Bertrand, H., Kampunzu, A.B., Tshoso, G., Watkeys, M.K., Le Gall., B. (2005), Karoo large igneous province: Brevitiy, origin, and relation to mass extinction questioned by new ${ }^{40} \mathrm{Ar} /{ }^{39} \mathrm{Ar}$ age data, Geology, vol. 33, p. 745-748.

Kelley, K.A. and Cottrell, E. (2009), Water and the oxidation state of subduction zone magmas, Science, 325, 605-607.

Kirkland, C.L., Smithies, R.H., Taylor, R.J.M., Evans, N., McDonald, B. (2015), Zircon Th/U ratios in magmatic environs, Lithos, 212-215, 397-414.

Kleiman, L.E. and Salvarredi, J.A. (2001), Petrología, geoquímica, e implicancias tectónicas del volcanismo triásico (Formación Puesto Viejo), Bloque de San Rafael, Mendoza, Revista de la Asociación Geológica Argentina, 56 (4), 559-570.

Kleiman, L.E., and Japas, M.S. (2009), The Choiyoi volcanic province at $34^{\circ} \mathrm{S}-36^{\circ} \mathrm{S}$ (San Rafael, Medoza, Argentina): Implications for the Late Palaeozoic evolution of the southerwestern margin of Gondwana, Tectonophysics, v. 473, p. 283-299.

Kohn, M.J., Corrie, S.L. (2011), Preserved Zr-temperatures and U-Pb ages in high-grade metamorphic titanite; evidence for a static hot channel in the Himalayan orogen. Earth and Planetary Science Letters, 311 (1-2), 136-143.

Kylander-Clark, A.R.C., Hacker, B.R., Cottle, J.M. (2013), Laser-ablation split-stream ICP petrochronology, Chemical Geology, 345, 99-112.

Lanci, L., Tohver, E., Wilson, A., Flint, S. (2013), Upper Permian magnetic stratigraphy of the lower Beaufort Group, Karoo Basin, Earth and Planetary Science Letters, 375, 123-134.

Lawver, L.A., Gahagan, L.M., Cofffin, M.F. (1992), The development of paleoseaways around Antarctica, Antarctic Research Series, vol 56, p. 7-30.

Lichte, F.E., Meier, A.L., and Crock, J.G. (1987), Determination of the rare-earth elements in geological materials by inductively coupled plasma mass spectrometry. Analytical Chemistry, 59, 1150-1157.

Li, X.-H., Liang, X., Sun, M., Liu, Y., Tu, X. (2000), Geochronology and geochemistry of singlegrain zircons; simultaneous in-situ analysis of $\mathrm{U}-\mathrm{Pb}$ age and trace elements by LAM-ICP- 
MS. European Journal of Mineralogy, 12 (5), 1015-1024.

Longerich H. P., Jenner G.A., Fryer B.J., and Jackson S.E. (1990), Inductively coupled plasmamass spectrometric analysis of geological samples: A critical evaluation based on case studies. Chemical Geology, 83, 105-118.

López-Gamundi, O.R. \& Rossello, E.A. (1998), Basin fill evolution and paleotectonic patterns along the Samfrau geosyncline: the Sauce Grande basin-Ventana foldbelt (Argentina) and Karoo basin-Cape foldbelt (South Africa) revisited, Geol. Runcsch., 86, 819-834.

Ludwig, K.R., 2009, Squid 2, A user's manual, Berkeley Geochronology Center Special Publication No. 5, p. 110.

Ludwig, K.R., 2012, Isoplot 3.75, a geochronological toolkit for Excel, Berkeley Geochronology Center Special Publication No. 5, p. 75.

Mantle, G.W. and Collins, W.J. (2008), Quantifying crustal thickness variations in evolving orogens: Correlation between arc basalt composition and Moho depth, Geology, vol. 36 (1), p. 87-90.

McClelland, W.C., Gilotti, J.A., Mazdab, F.K., Wooden, J.L. (2009), Trace-element record in zircons during exhumation from UHP conditions, North-East Greenland Caledonides. European Journal of Mineralogy, 21 (6), 1135-1148.

McKay, M.P., Weislogel, A.L., Fildani. A., Brunt. R.L., Hodgson, D.M., Flint, S.S. (2015), U$\mathrm{Pb}$ zircon tuff geochronology from the Karoo Basin, South Africa: implications of zircon recycling on stratigraphic age controls, International Geology Review, 57 (4), p. 393-410, 10.1080/00206814.2015.1008592

McLachlan, I.R., Jonker, J.P. (1990), Tuff beds in the northwestern part of the Karoo Basin, South African Journal of Geology, vol. 92 (2), p. 329-338.

Millar, I.L., Pankhurst, R.J., Fanning, C.M. (2002), Basement chronology of the Antarctic Peninsula: recurrent magmatism and anataxis in the Palaeozoic Gondwana margin, Journal of the Geological Society, London, vol. 159, p. 145-157.

Moyen, J. (2009), High Sr/Y and La/Yb ratios: the meaning of the "adakitic signature", Lithos, vol. $112(3)$, p. 556-574.

Ottone, E.G., Monti, M., Marsicano, C.A., de la Fuente, M.S., Naipauer, M., Armstrong, R., Mancuso, A.C. (2014), A new Late Triassic age for the Puesto Viejo Group (San Rafael depocenter, Argentina): SHRIMP U-Pb zircon dating and biostratigraphic correlations across southern Gondwana, Journal of S. American Earth Sciences, vol. 56, p. 186-199. 
Pankhurst, R.J., Rapela, C.W., Fanning, C.M., Márquez, M. (2006), Gondwanide continental collusion and the origin of Paragonia, Earth-Science Reviews, vol. 76, p. 235-257.

Pearce, J.A., Harris, N.B.W., Tindle, A.G. (1984), Trace element discrimination diagrams for the tectonic interpretation of granitic rocks, Journal of Petrology, vol. 25 (4), p. 956-983.

Perkins, M.E. \& Nash, B.P (2002), Explosive silicic volcanism of the Yellowstone hotspot: The ash fall tuff record, GSA Bulletin, 114 (3), 367-381.

Riley, T.R., Flowerdew, M.J., Whitehouse, M.J. (2012), U-Pb ion-microprobe zircon geochronology from the basement inliers of eastern Graham Land, Antarctic Peninsula: Journal of the Geological Society, London, no. 169, p. 381-393. doi: 10.11440016-76492011-142

Rocha-Campos, A.C., Basei, M.A.S., Nutman, A.P., and Dos Santos, P.R. (2006), SHRIMP U-Pb zircon geochronological calibration of the Late Paleozoic supersequence, Paraná Basin, Brazil, V South American Symposium on Isotope Geology, Punta del Este: Short Papers, p. $298-301$.

Rocha-Campos, A.C., Basei, M.A.S., Nutman, A.P., Kleiman, L.E., Varela, R., Llambías, E., Canile, F.M., da Rosa, O. de C.R. (2011), 30 million years of Permian volcanism recorded in the Choiyoi igneous province (W Argentina) and their source for younger ash fall deposits in the Paraná Basin: SHRIMP U-Pb zircon geochronology evidence, Gondwana Research, 19, 509-523.

Ramos, V.A., and Kay, S.M. (1991), Triassic rifting and associated basalts in the Cuyo basin, central Argentina, GSA Special Papers, v. 265, p 79-92.

Rubatto, D. (2002), Zircon trace element geochemistry: partitioning with garnet and the link between U-Pb ages and metamorphism, Chemical Geology, 184 (1-2), 123-138.

Rubbatto, D. and Hermann, J. (2007), Experimental zircon/melt and zircon/garnet trace element partitioning and implications for the geochronology of crustal rocks, Chemical Geology, vol. 241 (1), p. 38-61.

Rubidge, B.S., Erwin, D.H., Ramezani, J., Bowring, S.A., de Klerk, W.J. (2013), High-precision temporal calibration of Late Permian vertebrate biostratigraphy: $\mathrm{U}-\mathrm{Pb}$ zircon constraints from the Karoo Supergroup, South Africa, Geology.

Schmitt, A.K., Wetzel, F., Cooper, K.M., Zou, H., Wörner, G. (2010), Magmatic longevity of Laacher See volcano (Eifel, Germany) indicated by U-Th dating of intrusive carbonatites, J. Petrology, 51 (5), 1053-1085.

Schoene, B., Schlategger, U., Brack, P., Latkoczy, C., Stracke, A., Günther, D. (2012), Rates of 
magma differentiation and emplacement in a ballooning pluton recorded by U-Pb TIMSTEA, Adamello batholith, Italy, Earth and Planetary Science Letters, 355-356, 162-173.

Sircombe, K.N., and Stern, R.A. (2002), An investigation of artificial biasing in detrital zircon $\mathrm{U}-\mathrm{Pb}$ geochronology due to magnetic separation in sample preparation: Geochimica Et Cosmochimica Acta, no. 66, p. 2379-2397. doi:10.1016/S0016-7037(02)00839-6.

Spalletti, L.A., Fanning, C.M., Rapela, C.W. (2008), Dating the Triassic continental rift in the southern Andres: the Potrerillos Formation, Cuyo Basin, Argentina, Geologica Acta, vol. $6(3)$, p. 267-283.

Stacey, J. and Kramers, J.D. 1975, Approximation of terrestrial lead isotope evolution by a twostage model: Earth and Planetary Science Letters, 26, 207-221.

Taylor, H.E. \& Lichte, F.E. (1980), Chemical composition of Mount St. Helens volcanic ash, Geophysical Research Letters, 7 (11), 949-952.

Tomlinson, E.L., Albert, P.G., Wulf, S., Brown, R.J., Smith, V.C., Keller, J., Orsi, F., Bourne, A.J., Menzies, M. (2014), Age and geochemistry of tephra layers from Ischia, Italy: constraints from proximal-distal correlations with Lago Grande di Monticchio, Journal of Volcanology and Geothermal Research, 287, 22-39.

Veevers, J.J., Cole, D.I., Cowan, E.J. (1994), Southern African: Karoo basin and Cape fold belt, in Veevers, J.J. and Powell, C.M., eds. Permian-Triassic Pangean basins and Foldbelts along the Panthalassan margin of Gondwanaland: Boulder, Colorado, G.S.A. Memoir, v. 184, p. 223-279.

Watson, E.B., and Harrison, T.M. (1983), Zircon saturation revisited: temperature and composition effects in a variety of crustal magma types, Earth and Planetary Science Letters, v. 64, p. 295-304, doi: 10.1016/0012-821X(83)90211-X.

Watson, E.B., and Harrison, T.M. (2005), Zircon thermometer reveals minimum melting conditions on earliest Earth, Science, 308, 841-844.

Watson E.B., Wark D.A., Thomas J.B. (2006), Crystallization thermometers for zircon and rutile, Contrib. Mineral. Petrol., 151:413-433.

Winchester, J.A. \& Floyd, P.A. (1977), Geochemical discrimination of different magma series and their differentiation products using immobile elements, Chemical Geology, 20, 325-343. 


\title{
CHAPTER 3: TIMS, LA-ICPMS, AND SHRIMP PROVIDE DIFFERENT AGES FOR COMPLEX, POLYSTAGE ZIRCON: INHERITANCE OR PB-LOSS?
}

\begin{abstract}
Absolute ages for geologic strata are increasingly based on $\mathrm{U}-\mathrm{Pb}$ isotope analysis of the mineral zircon using three commonly applied techniques: Chemical Abrasion Thermal Ionization Mass Spectrometry (CA-TIMS), Laser Ablation Inductively Coupled Mass Spectrometry (LAICPMS), and Sensitive High Resolution Ion Microprobe (SHRIMP). We present 15 TIMS and 109 LA-ICPMS ages in addition to 13 depth profiled SHRIMP U-Pb ages for zircon grains from volcanic tuffs interbedded in sedimentary strata of the Permian-Triassic Karoo Supergroup in South Africa. Zircon selected for CA-TIMS analyses were chemically abraded prior to analysis, significantly reducing the effects of Pb-loss, while grains for LA-ICPMS and SHRIMP analyses were not treated. CA-TIMS results from the Upper Ecca Group are 264.7 to 274.5 Ma with a population of 10 (of 12) at $268 \mathrm{Ma}$. These ages are comparable to 255 to $295 \mathrm{Ma}$ LA-ICPMS results with a weighted mean age of $272.3 \pm 1.2 \mathrm{Ma}(\mathrm{MSWD}=1.9 ; \mathrm{n}=68)$ from the same stratigraphic interval. SHRIMP results from the same stratigraphic interval, however contain a significant population of $<260 \mathrm{Ma}$ (weighted mean=253.7 \pm 1.0 ; $\mathrm{MSWD}=1.7 ; \mathrm{n}=53$ ) grains in addition to a middle Permian population with a weighted mean=267.9 $\pm 0.98(\mathrm{MSWD}=2.5 ; \mathrm{n}=88) \mathrm{Ma}$. Three zircon from volcanic tuffs in the overlying Beaufort Group fluvial strata yielded TIMS ages of 256.3, 262.5, 267.6 Ma; the 256.3 Ma grain is younger than $100 \%$ of LA-ICPMS and $95 \%$ of SHRIMP ages from the same stratigraphic group. Cathodoluminescence (CL) images of zircon grains suggest polyphase zircon growth and Ti-in-zircon temperature estimates and $\mathrm{Zr}$ saturation temperatures are compatible with "cold, inheritance-rich" magmatism. Since LA-ICPMS and CA-TIMS require analyzing exponentially larger aliquots and SHRIMP microanalyses provide increased spatial resolution, SHRIMP analyses may resolve the age of thin, highly complex zircon overgrowths that are unresolvable by LA-ICPMS and CA-TIMS approaches.
\end{abstract}

To be submitted to Terra Nova as: McKay, M.P., Weislogel, A.L., Fildani, A., TIMS, LA-ICPS, and SHRIMP provide different ages for complex, polystage zircon: Inheritance or Pb-loss? 


\section{INTRODUCTION}

$\mathrm{U}-\mathrm{Pb}$ zircon geochronology has become one of the most widely used approaches to date magmatism, metamorphism, and sediment deposition (Harley et al., 2007; Lawton, 2014; Kirkland et al., 2015). Since zircon is chemically and mechanically robust it resists mechanical abrasion during magmatic and sedimentary transport and dissolution that may occur during surficial weathering or within long-lived magma systems. The durability of zircon results in grains being recycled through many generations of magmatism, erosion, and sedimentation (Belousova et al., 2006; Thomas, 2011). Magmatic systems frequently recycle older, inherited grains over millions of years, which may provide misleading ages for magmatism in inheritance rich igneous rocks (Compston, 2000; Compston and Gallagher, 2012). Additionally, the high U content of zircon grains can result in radiation damage to the crystal lattice of the mineral. This damaged lattice can led to loss of $\mathrm{Pb}$ through diffusion (Mattinson, 2005). Zircon grains may also have multiple stages of crystal growth during the complex evolution of a magmatic system, resulting in older cores with younger rims (Belousova et al., 2006). This complexity is frequently encountered in zircon geochronology studies and can be addressed by (1) eliminating analyses that are interpreted as "too old", (2) discounting high U, possibly discordant analyses that are "too young" and may be due to $\mathrm{Pb}$ loss, (3) removal of zircon through chemical or mechanical processes that are likely to be affected by $\mathrm{Pb}$ loss, and (4) employing microanalysis to target specific zones within zircon to avoid mixing different age domains within single grains.

Approaches to minimize the effects of inheritance, $\mathrm{Pb}$ loss, and age domain mixing are used differently depending on the analytical technique used to collect $\mathrm{U}-\mathrm{Pb}$ isotope data: (1) Isotope dilution-thermal ionization mass spectrometry (ID-TIMS), (2) Laser ablation-inductively coupled mass spectrometry (LA-ICPMS), and (3) Secondary ion mass spectrometry (SIMS; this study and previously published SIMS ages are from the Sensitive High Resolution Ion Microprobe [SHRIMP], a SIMS instrument, at the Stanford Univ. Microanalytical Center). ID-TIMS analysis requires complete dissolution of the zircon grain by $\mathrm{HF}$ acid digestion, which precludes any spatial resolution of age domains within a grain. It is therefore crucial to analyze grains that show no evidence for complex zoning (Parrish and Noble, 2003). To avoid the potential effects of Pb-loss in ID-TIMS analyses, grains are commonly abraded mechanically using the air abrasion technique (Goldich and Fischer, 1986) or chemically using HF leaching steps and high temperature annealing (Chemical abrasion-CA-ID-TIMS; Mattinson, 2005).

Chemical abrasion can be applied to samples prior to SHRIMP and LA-ICPMS analyses (Kryza et al., 2012). However, SHRIMP and LA-ICPMS microanalyses can be collected more rapidly and the effects of $\mathrm{Pb}$-loss are commonly mitigated by eliminating high $\mathrm{U}$, younger analyses 
that do not form coherent age populations. For complex zircon grains, microanalytical techniques are preferred (Parrish and Noble, 2003) to avoid mixing of age domains yielding a misleading or erroneous result. LA-ICPMS and SHRIMP techniques allow for the analyses of exponentially smaller aliquots that are spatially sampled using laser ablation or secondary ion microprobe, respectively, to bombard selected domains. LA-ICPMS typically analyses a spot of $\sim 30$ um wide and $~ 15$ um deep, while SHRIMP provides greater resolution in the form of a shallower analytical pit that is commonly $\sim 25$ um wide but only $\sim 2$ um deep. Spatial resolution during microanalyses comes at the expense of precision. TIMS analyses can yield ages with $1 \sigma$ uncertainties as low as $0.025 \%$. SHRIMP and LA-ICPMS analyses uncertainties can be an order of magnitude larger and generally range from an uncertainty of $<1-4 \%(1 \sigma)$. Typically, SHRIMP provides lower uncertainties; in this study SHRIMP analyses for the same suite of tuffs yielded an average $1 \sigma$ uncertainty of $1.5 \%$; while the average uncertainty for LA-ICPMS analyses is $2 \%$. For rocks of Permo-Triassic age, that equates to LA-ICPMS analyses providing $1 \sigma$ uncertainty ranges that are $>2.5$ m.y. greater than that of SHRIMP results.

To test the variability that can be observed within each analytical approach, we present LA-ICPMS, and TIMS ages for zircon from volcanic tuffs in the Karoo Supergroup strata of South Africa. Tuffs in the Karoo Supergroup are of Gondwanan affinity and commonly contain complex zircon populations. While some suggest that Permian-Triassic volcanic rocks from Gondwana contain large populations of recycled zircon (Domeier et al., 2010; Ottone et al., 2014; McKay et al., 2015) in younger Permian-Triassic tuffs, Pb-loss has also been 'blamed' to account for late Permian and Triassic zircon population in strata that is thought to be significantly older (>15 Ma) (Lanci et al, 2013). No evidence for Pb-loss, however, can be documented since younger ages do not correlate to higher $\mathrm{U}$ concentrations and age results are repeatable. To address the relationship of Pb-loss and inheritance in Gondwana tuffs, we compare TIMS and LA-ICPMS results to previously published SHRIMP U-Pb results from the same suite of tuffs (McKay et al., 2015; in review) and discuss the disparity in U-Pb ages from SHRIMP, LA-ICPMS, and TIMS ages, and note an increasingly likely of age component mixing with increased sample aliquot volume relative to decreasing spatial resolution.

\section{GEOLOGIC BACKGROUND}

The Karoo Basin of South African is composed of clastic strata deposited in the Gondwanide foreland basin that contain numerous interbedded tuff horizons. Tuff geochronology studies have focused on intervals in the marine Ecca Group and overlying, fluvial Beaufort Group. The results, however, have been paradoxical. Ecca Group tuffs record a younging upward sequence of U-Pb zircon ages that range from $\sim 275$ to $\sim 250 \mathrm{Ma}$, as resolved by SHRIMP (Fildani et al., 2007; 2009; 
McKay et al., 2015). Overlying Beaufort Group tuffs, however, contain the same age range from 268-252 Ma even though Beaufort strata postdate the underlying Ecca Group (Veevers et al., 1994). Zircon from Beaufort Group tuffs have been dated using both TIMS and SHRIMP (TIMS: Coney et al., 2007; Rubdige et al., 2013; SHRIMP: Lanci et al., 2013; McKay et al., 2015; in review) and the results are complimentary. ${ }^{40} \mathrm{Ar} /{ }^{39} \mathrm{Ar}$ ages of detrital mica of $<250 \mathrm{Ma}$ from the lower Beaufort Group suggest, however that the Beaufort Group is likely Triassic (Hälbich et al., 1983; Arosio, 2012), which supports the age interpretation of the underlying Ecca as early to late Permian (Fildani et al., 2009; McKay et al., 2015) and the zircon in Beaufort tuffs may be recycled and not represent absolute depositional ages (McKay et al., 2015).

\section{METHODS}

TIMS

Of the 590 total SHRIMP analyses (presented by McKay et al., 2015, in review), 16 grains ranging from 237 to $258 \mathrm{Ma}$ were selected for TIMS analyses (Fig. 1). Grains were (1) picked from epoxy SHRIMP mounts and (2) pre-pretreated using chemical abrasion and thermal annealing as described by Mattingson (2005). Sample preparation and analyses was conducted by the ACTLABS Geochronology and Isotopic Geochemistry team. Grains were then (3) placed in Teflon vials along with the EARTHTIME ET535 ${ }^{205} \mathrm{~Pb}^{233} \mathrm{U}^{235} \mathrm{U}$-spike (Condon et al., 2015) and (4) dissolved in $\mathrm{HF}$ at $220^{\circ} \mathrm{C}$ in a pressure vessel for $48-60$ hours. (5) $\mathrm{U}$ and $\mathrm{Pb}$ ions were then separated using ion-exchange chromatography (Parrish and Noble, 2003) and (6) measured using a VG Sector 54 multi-collector TIMS. Due to the small grain size, 2 grains were completely dissolved or lost during chemical abrasion.

\section{$L A-I C P M S$}

Four samples were selected for U-Pb zircon analyses using the University of Arizona Laserchron Center LA-ICPMS. Zircon grains were mounted in epoxy and polished to expose a cross section of the grain. Samples were ablated using a Photon Machines Analyte G2 Excimer laser with a spot size of $\sim 30$ um (Gehrels et al., 2008). Isotope ratios were corrected to the University of Arizona Sri Lanka zircon standard (Gehrels et al., 2008). Analyses, like SHRIMP results, that are discordant, >>300 Ma, high common $\mathrm{Pb}$, or high $\mathrm{U}$ are disregarded for further analysis.

\section{SHRIMP}

Grains that were interpreted to have multiple zircon are domains were extracted from epoxy mounts and placed in an iridium mounts, with the external crystal face exposed. The grain was then bombarded by the SHRIMP ion-beam (under analytical conditions described in McKay 


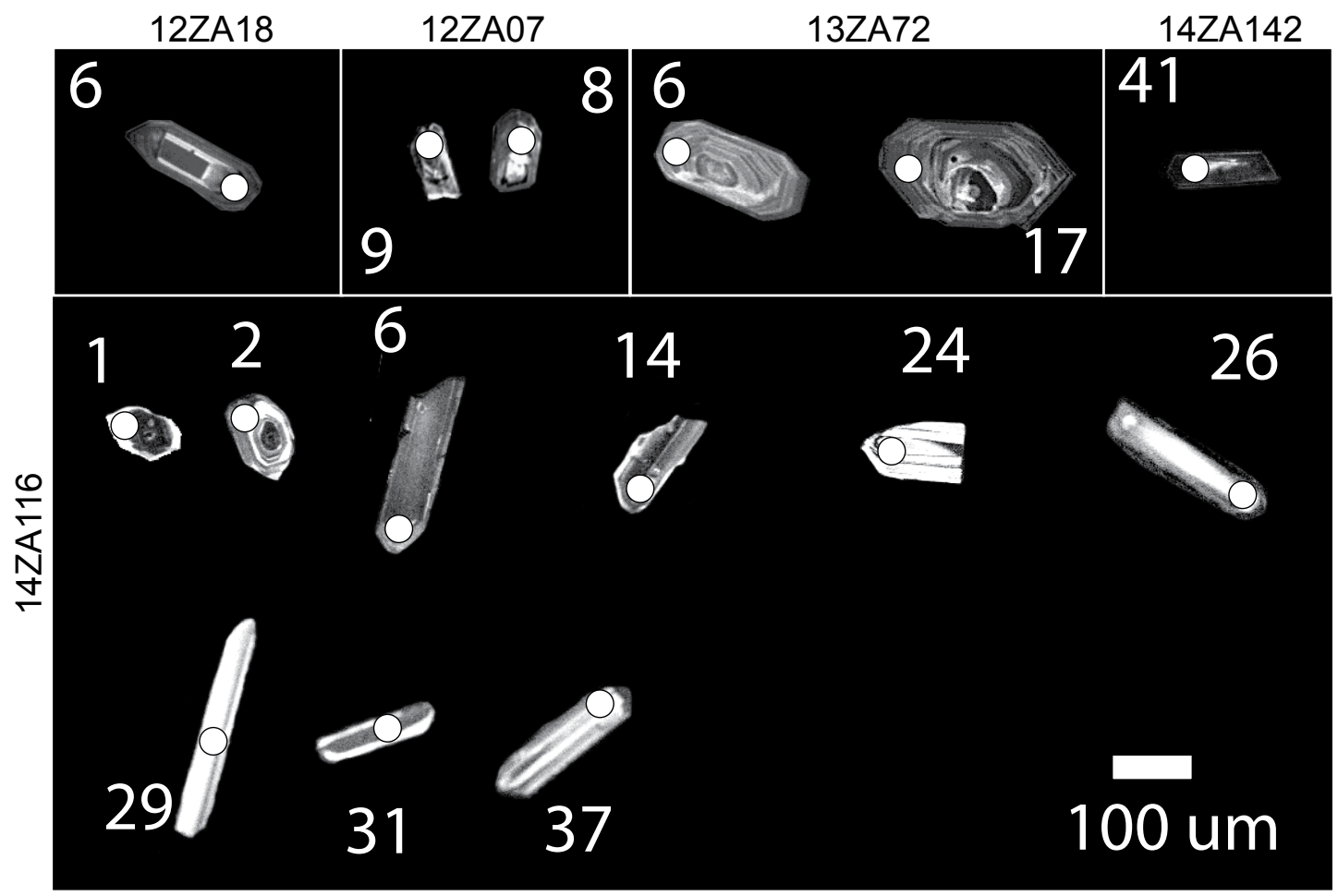

Figure 1: CL images of analyzed zircon grains reveals complex grains, which could correlate to polygrowth zircon, affecting higher volume sampling techniques.

et al., 2015) to obtain $\mathrm{U}-\mathrm{Pb}$ isotopic ratios for small rims of Karoo tuff zircon. High common $\mathrm{Pb}$ or high U analyses, like LA-ICPMS results, were disregarded.

\section{RESULTS}

Results are grouped into three stratigraphic intervals to present a more representative dataset: (1) the Lower Ecca Group marine sediments, (2) Upper Ecca marine to marginal marine strata, and (3) Beaufort Group fluvial strata. While these units were likely deposited diachronously (Rubidge et al., 2000), geochronology and the distribution of tuffs stratigraphically suggest only minor age variability (Fildani et al., 2009; McKay et al., 2015) across the field area.

\section{$T I M S$}

Zircon from tuffs in the Upper Ecca Group $(\mathrm{N}=3 ; \mathrm{n}=11)$ yielded 9 of 11 Permian ages are within 1 m.y. of $268 \mathrm{Ma}$ (Fig. 2B), with two outliers with ages of 264.74 and $274.55 \mathrm{Ma}$. While only a limited number of analyses were collected, zircon from tuffs in the Beaufort Group ( $\mathrm{N}=2$, $\mathrm{n}=3$; Fig. 2C) produced a range of ages with no populations, with ages of 256.30, 262.50, 267.63 $\mathrm{Ma}$; the uncertainties for these three ages are low $0.13,0.13$, and $0.47 \mathrm{~m}$.y respectively, with no ages overlapping within uncertainty (Table 1). 


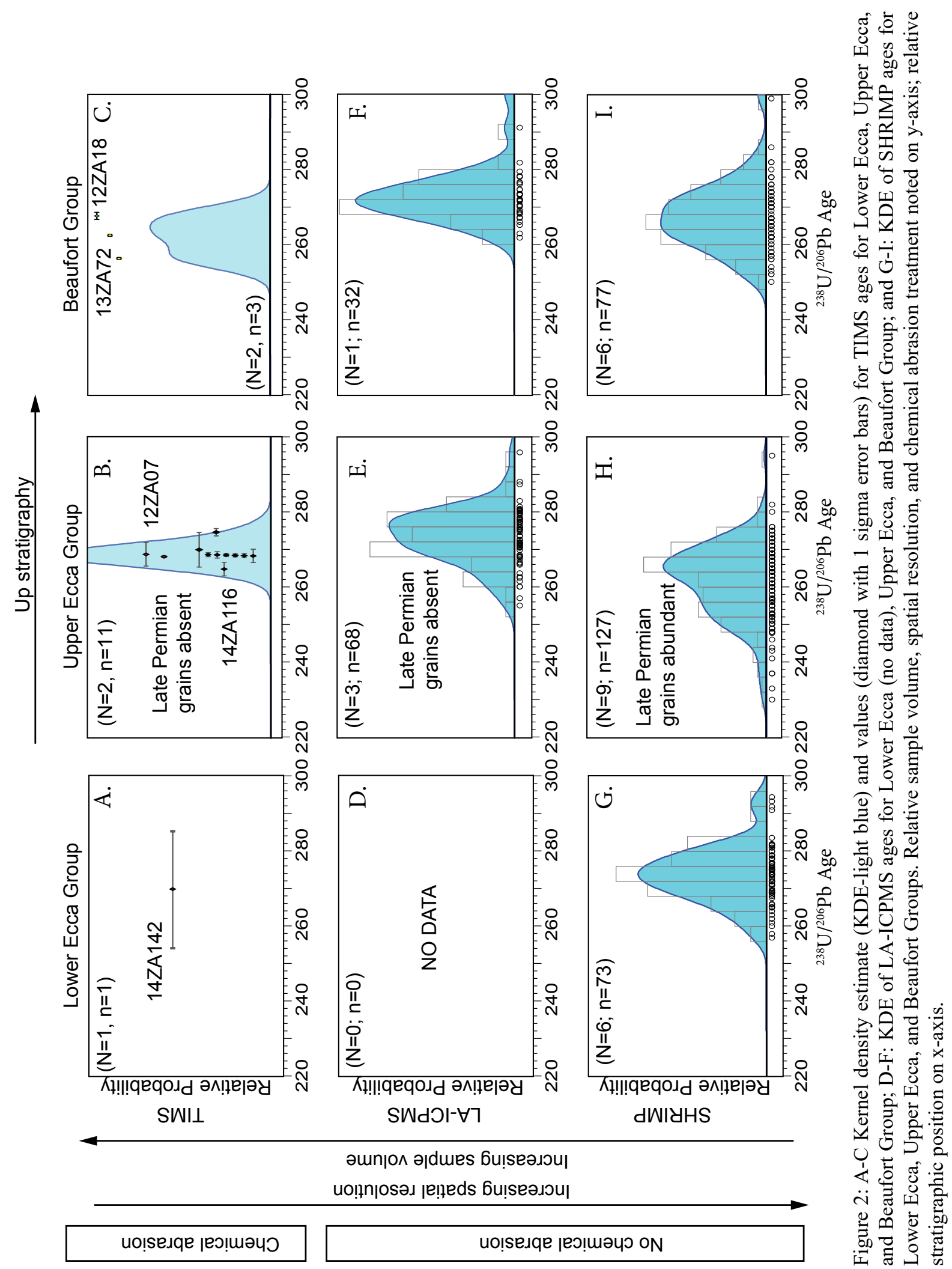


TABLE 1-TIMS U-Pb ages

\begin{tabular}{|c|c|c|c|c|c|c|c|c|c|c|}
\hline Grain & $\mathrm{Th} / \mathrm{U}$ & $206 \mathrm{~Pb} / 238 \mathrm{U}$ & $2 \sigma \%$ & $207 \mathrm{~Pb} / 235 \mathrm{U}$ & $2 \sigma \%$ & $207 \mathrm{~Pb} / 206 \mathrm{~Pb}$ & $2 \sigma \%$ & $\begin{array}{l}\text { Corr. } \\
\text { Coef. }\end{array}$ & $\begin{array}{c}206 / 238 \\
\text { Age (Ma) }\end{array}$ & $2 \sigma$ \\
\hline $12 Z A 07-6$ & \multicolumn{10}{|c|}{ Dissolved during chemical abrasion } \\
\hline $12 Z A 07-8$ & 0.66 & 0.042557 & 0.59 & 0.30720 & 7.43 & 0.05238 & 7.28 & 0.293 & 268.66 & 1.56 \\
\hline 12ZA07-9 & 0.8 & 0.042454 & 0.05 & 0.30297 & 0.28 & 0.05178 & 0.26 & 0.407 & 268.03 & 0.14 \\
\hline 13ZA72A-6 & 0.66 & 0.040560 & 0.05 & 0.28758 & 0.17 & 0.05145 & 0.14 & 0.522 & 256.3 & 0.13 \\
\hline 13ZA72A-17 & 0.66 & 0.041560 & 0.05 & 0.29542 & 0.19 & 0.05158 & 0.17 & 0.456 & 262.5 & 0.13 \\
\hline 14ZA116-1 & 0.66 & 0.041922 & 0.35 & 0.30556 & 4.35 & 0.05289 & 4.26 & 0.297 & 264.7 & 0.91 \\
\hline 14ZA116-2 & 0.5 & 0.042758 & 0.87 & 0.33327 & 10.80 & 0.05655 & 10.59 & 0.281 & 269.9 & 2.31 \\
\hline 14ZA116-6 & 0.78 & 0.042490 & 0.34 & 0.30925 & 3.41 & 0.05281 & 3.34 & 0.275 & 268.25 & 0.88 \\
\hline 14ZA116-14 & 0.66 & 0.042526 & 0.08 & 0.30361 & 0.61 & 0.05180 & 0.59 & 0.322 & 268.47 & 0.20 \\
\hline 14ZA116-24 & 1.25 & 0.043509 & 0.18 & 0.31853 & 2.08 & 0.05312 & 2.03 & 0.295 & 274.55 & 0.49 \\
\hline 14ZA116-26 & 0.78 & 0.042534 & 0.16 & .30478 & 1.81 & 0.05199 & 1.77 & 0.295 & 268.52 & 0.42 \\
\hline 14ZA116-29 & 0.78 & 0.042500 & 0.11 & 0.30389 & 1.07 & 0.05188 & 1.05 & 0.285 & 268.31 & 0.28 \\
\hline 14ZA116-31 & 0.63 & 0.042544 & 0.1 & .030556 & 0.96 & 0.05211 & 0.93 & 0.312 & 268.58 & 0.27 \\
\hline 14ZA116-37 & 0.70 & 0.042514 & 0.08 & 0.30410 & 0.82 & 0.05190 & 0.80 & 0.210 & 268.39 & 0.21 \\
\hline 12ZA18-6 & 0.35 & 0.042390 & 0.18 & 0.30625 & 2.17 & 0.05242 & 2.14 & 0.284 & 267.63 & 0.47 \\
\hline 12ZA23-11 & \multicolumn{10}{|c|}{ Dissolved during chemical abrasion } \\
\hline 14ZA142-41 & 1.1 & 0.042734 & 2.93 & 0.38998 & 24.04 & 0.06622 & 23.08 & 0.38 & 269.76 & 7.75 \\
\hline
\end{tabular}

Extended dataset available in Electronic Appendix.

\section{$L A-I C P M S$}

While no samples from the Lower Ecca Group were analyzed via LA-ICPMS, tuffs that were erupted during Lower Ecca deposition have tightly coherent zircon populations and, as such, do not show evidence of zircon recycling (McKay et al., 2015). LA-ICPMS U-Pb zircon ages from the Upper Ecca Group (Fig. 2E; analytical results in Appendix F) range from 255-1070 Ma (N=3; $\mathrm{n}=73$ concordant analyses). LA-ICPMS analyses fall into one coherent population that ranges from 260-283 Ma, with a weighted average of 272.3 Ma $\pm 1.2(\mathrm{MSWD}=1.9 ; \mathrm{n}=68)$. A histogram of $\mathrm{U}-\mathrm{Pb}$ of LA-ICPMS ages suggest two subpopulations at $\sim 269$ and $\sim 279 \mathrm{Ma}$, however uncertainties on LA-ICPMS analyses preclude definitely splitting these populations. Two outlying ages of 255 and $257 \mathrm{Ma}$ may represent minor Pb-loss or a geologically meaningful, albeit small population; these analyses, however, have $1 \sigma$ uncertainties of 8 and $5 \mathrm{Ma}$, respectively, that significantly overlap with $1 \sigma$ uncertainties of zircon analyses within the 260-283 Ma population.

Beaufort Group tuff zircon (Fig. 2F) yielded LA-ICPMS ages that range from 422 to 261 Ma $(\mathrm{N}=1 ; \mathrm{n}=34$ concordant analyses). Permian-Triassic grains form one population that falls between 261-282 Ma that forms a statistical peak around $271 \mathrm{Ma}$, with three, older outliers at 291, 300 , and $422 \mathrm{Ma}$. No anomalously young grains were excluded and no observed $\mathrm{Pb}$-loss ages were interpreted. 
TABLE 2-SHRIMP Depth Profiled U-Pb ages

\begin{tabular}{|c|c|c|c|c|c|c|c|c|}
\hline Spot & $\begin{array}{c}\text { Comm Pb } \\
\text { \%206 }\end{array}$ & $\begin{array}{c}U \\
(\mathrm{ppm})\end{array}$ & $\begin{array}{c}\text { Th } \\
\text { (ppm) }\end{array}$ & $\begin{array}{l}\text { 206/238 } \\
\text { Age (Ma) }\end{array}$ & $1 \sigma$ & $\begin{array}{l}\text { 207/206 } \\
\text { Age (Ma) }\end{array}$ & $1 \sigma$ & Disc\% \\
\hline 12ZA18-13.1 & 9.8 & 873 & 241 & 207 & 4 & -6 & 4362 & 3469 \\
\hline 12ZA18-6.1 & -0.1 & 410 & 149 & 250 & 1 & 211 & 102 & -19 \\
\hline 12ZA18-6.1 & -0.1 & 374 & 121 & 254 & 2 & -125 & 252 & +307 \\
\hline 12ZA18-6.1 & 0.0 & 363 & 136 & 234 & 3 & 225 & 48 & -4 \\
\hline 12ZA18-6.2 & 0.3 & 420 & 145 & 261 & 3 & 161 & 136 & -62 \\
\hline 13ZA72-1.1 & 0.6 & 183 & 181 & 235 & 3 & 41 & 334 & -476 \\
\hline 13ZA72-1.1 & 0.1 & 272 & 315 & 223 & 2 & 243 & 69 & +8 \\
\hline 12ZA23-10.1 & 53.5 & 241 & 478 & 161 & 7 & 2535 & 492 & +94 \\
\hline 12ZA23-11.1 & 13.9 & 258 & 196 & 246 & 2 & 1984 & 159 & +88 \\
\hline 12ZA23-9.1 & 42.9 & 436 & 492 & 174 & 15 & & & \\
\hline 12ZA23-9.2 & 49.0 & 125 & 223 & 438 & 7 & 1584 & 1332 & +92 \\
\hline 12ZA23-9.3 & 33.7 & 125 & 458 & 492 & $\theta$ & 4925 & 701 & +90 \\
\hline 12ZA61-4.1 & 2.8 & 491 & 359 & 264 & 4 & 1428 & 143 & +82 \\
\hline
\end{tabular}

Extended dataset available in Electronic Appendix.

\section{SHRIMP}

SHRIMP depth profiles of 7 grains from the Beaufort Group and 6 grains from the Ecca Group produced 6 high common $\mathrm{Pb}\left(>20 \%{ }^{208} \mathrm{~Pb}\right)$ and 7 low common $\mathrm{Pb}$ ages. The only low common $\mathrm{Pb}$ age from the Ecca Group was $\sim 264 \mathrm{Ma}$, while low common $\mathrm{Pb}$ analyses from the Beaufort Group tuff zircon were, 223, 234, 235, 250, 254, 261 Ma (Table 2). Low common Pb analyses yielded moderate to low U concentrations less than $500 \mathrm{ppm}$.

\section{DISCUSSION}

TIMS and LA-ICPMS ages for tuff zircon in the Upper Ecca suggest early to middle Permian ages, while SHRIMP ages record late Permian to Early Triassic ages (Fig 2). The disparity in ages obtained using different instruments (TIMS, LA-ICPMS, SHRIMP-RG) appears to be restricted to zircon from tuffs in the Upper Ecca Group. While early and middle Permian ages are common throughout the stratigraphic section, late Permian zircon ages are restricted to Upper Ecca (Fildani et al., 2009; McKay et al., 2015) and upper-most Beaufort tuffs (Coney et al., 2007; Rubidge et al., 2013). The possible mechanisms responsible for the observed discrepancies between SHRIMP and TIMS/LA-ICPMS U-Pb age are: (1) instrumentational bias (2) common Pb contamination (3) non-zircon inclusions within zircon grains (4) Pb-loss in Upper Ecca tuff zircon and (5) recycling and inheritance of older grains with small, micron-scale zircon overgrowths. 
Instrumentational bias is unlikely since SHRIMP analyses corroborate Beaufort TIMS U$\mathrm{Pb}$ ages, not only in this study, but in previous geochronology efforts (Coney et al., 2007; Lanci et al., 2013; McKay et al., 2015). SHRIMP ages could be anomalously young (1) if the samples were contaminated with common $\mathrm{Pb}$ resulting in an anomalous common $\mathrm{Pb}$ correction, or (2) if the SHRIMP analyses hit a small inclusion, which are known to exist in volcanic zircon (Hoskin and Schaltegger, 2003). In contrast, LA-ICPMS and TIMS analyses would be less likely to be effected by small inclusions due to the increased volume of material sampled. During SHRIMP analyses, however, non-radiogenic ${ }^{204} \mathrm{~Pb}$ and ${ }^{208} \mathrm{~Pb}$ isotopes are measured, which provides a tool for quantitative assessment of common $\mathrm{Pb}$ contamination or the presence of non-zircon inclusions.

Cryptic Pb-loss could also account for younger, but still concordant ages from grains that have not been treated to remove damaged zones using chemical abrasion. In this case, LA-ICPMS and SHRIMP ages should both produce younger, $\mathrm{Pb}$-loss effected ages, since both datasets were collected from untreated zircon grains. LA-ICPMS ages, however, did not yield the young ages observed using SHRIMP. Although $\mathrm{Pb}$-loss can affect grains with a wide range of $\mathrm{U}$ concentrations (Mattinson, 2005), zircon from Karoo tuffs have relatively low U concentration (<1000 ppm) and no relationship was observed between $U$ content and age. SHRIMP ages collected by depth profiling record low $\mathrm{U}(<1000 \mathrm{ppm})$, low common $\mathrm{Pb}$ zircon domains from a single crystal from the Beaufort Group tuff (12ZA18), become older with increasing age (Fig 2). This suggests multiple stages of successive zircon growth and that zircon age ranges may be due to protracted magmatism and recycling of zircon grains in increasingly younger, more evolved magmas. If $\mathrm{Pb}$-loss were the controlling factor, age should decrease with increasing $U$ concentration, and the three depth profiled ages from grain 12ZA18-6 all exhibit a spread of ages at similar U concentrations $\sim 375-$ $425 \mathrm{ppm})$.

Figure 3: TIMS, LA-ICPMS, and SHRIMP analyses of zircon from tuffs in the Lower Beaufort Group show a discrepancies between the results from each technique. LA-ICPMS ages (12ZA16) are generally older than TIMS ages from the same stratigraphic interval. SHRIMP analyses from 12ZA18 suggests a $\sim 270$ Ma population that correlates to LAICPMS ages and a smaller, $\sim 238$ Ma population while zircons from 12ZA16 yield 265 Ma ages only, slightly younger than LA-ICPMS ages. SHRIMP depth profiled analyses (circles) of grains from 12ZA18 yielded domains younger than observed via TIMS, LA-ICPMS, or SHRIMP.

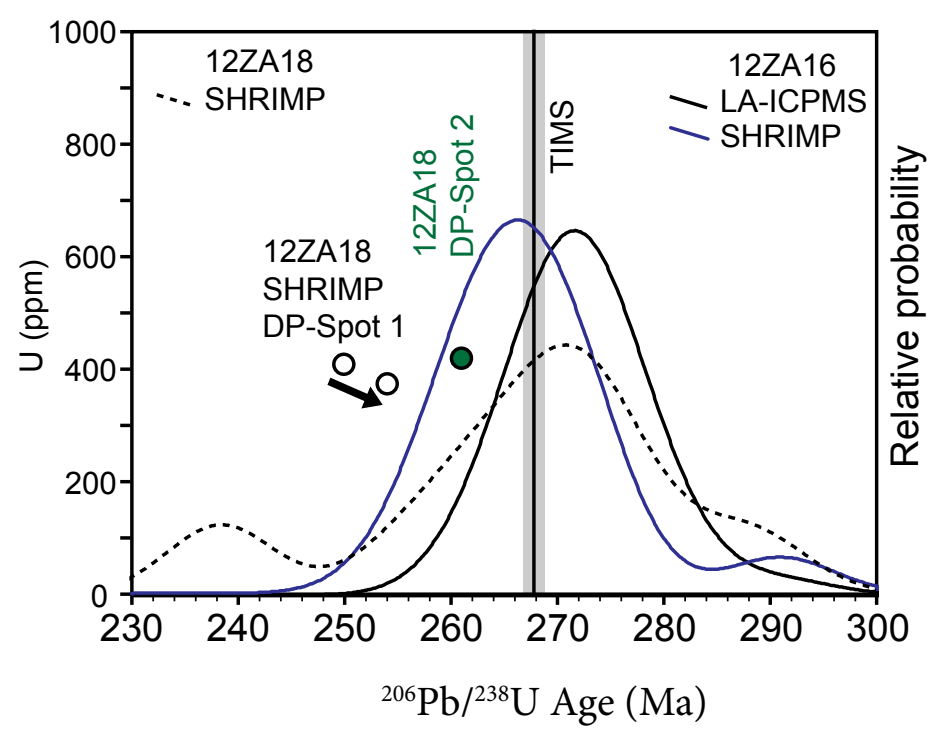


Figure 4: SHRIMP (yellow KDE) and TIMS (diamonds with error bars) analyses of zircons from 14ZA116 indicate that few SHRIMP analyses are within error of TIMS analyses. The lack of comparable age grains and scatter observed in both SHRIMP and higher precision TIMS suggest geologic age variability, i.e. mutiple age populations.

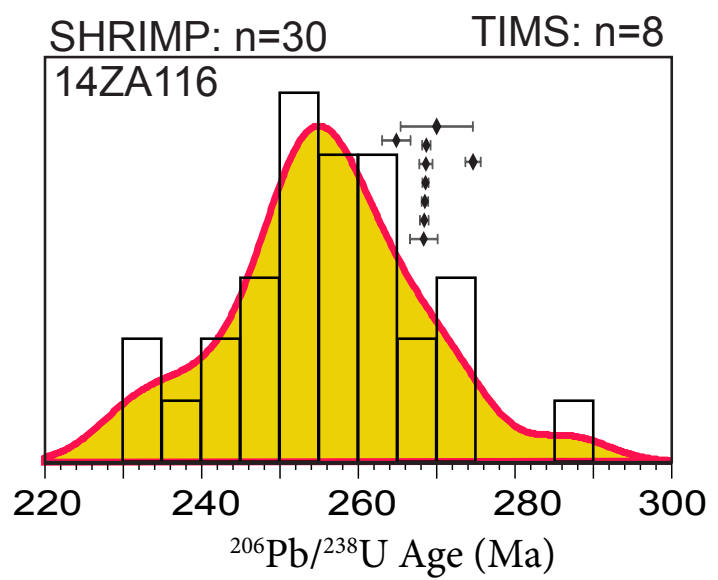

SHRIMP analyses of sample 14ZA116 resulted in only a single grain at 268 Ma that is compatible with its dominant TIMS age population of $268 \mathrm{Ma}$. If $\mathrm{Pb}$-loss were the culprit behind the age discrepancies between methods, then 14ZA116 would predictably contain a large population of $\sim 268$ ( \pm unspecified error) Ma SHRIMP ages, with a bell-shaped curve representing minor inheritance and Pb-loss. This distribution in ages, however, is entirely missing from the SHRIMP data for this sample (Fig. 4). In fact, the 268 Ma TIMS age population corresponds to a statistical low in the SHRIMP U-Pb age distribution. The lack of TIMS age populations in SHRIMP age data is not consistent with Pb-loss in Karoo tuff zircon.

Zircon populations in igneous rocks can record multiple generations of growth, and significantly older grains ( $>5$ m.y.) can be recycled in younger melts if (A) magmatic activity occurs rapidly or (B) if later stage magmatism remains near Zr saturation. The geochemistry of Karoo tuffs (McKay et al., in review), suggests that magmatism responsible for volcanism recorded in the Karoo Supergroup contained intermediate to low Zr concentrations ( $<500 \mathrm{ppm}$ ), particularly in the Upper Ecca and Beaufort groups, where significant age discrepancies occur between SHRIMP and TIMS results. Zr saturation estimates (McKay et al., in review; based on Watson and Harrison, 1983 ) suggest $\mathrm{Zr}$ saturation and therefore zircon crystallization would occur at $\mathrm{Zr}>115 \mathrm{ppm}$ at $750^{\circ} \mathrm{C}$ and $\mathrm{Zr}>225 \mathrm{ppm}$ at $800^{\circ} \mathrm{C}$. Lower Ecca Group tuffs have $\mathrm{Zr}$ concentrations of 129-453 ppm, with more than $50 \%$ of tuffs having $\mathrm{Zr}>\sim 225 \mathrm{ppm}$. At $\sim 750^{\circ} \mathrm{C}$, all Lower Ecca Group tuffs contain sufficient $\mathrm{Zr}$ to crystallize zircon, and over half contain $>225 \mathrm{ppm}$ and zircon growth would be predicted above $800^{\circ} \mathrm{C}$ (Fig. 5). Upper Ecca Group tuffs contain Zr ranging from 129-453 ppm, with 6 of 8 tuffs having $\mathrm{Zr}>225 \mathrm{ppm}$, with only one sample with $\mathrm{Zr}$ concentrations $<115 \mathrm{ppm}$ that would no predictably crystallize zircon. Beaufort Group tuffs Zr ranges from 118-258 ppm, and Ti-in-zircon suggest temperatures of no zircon crystallization and dissolution would dominate Beaufort tuffs at $800^{\circ} \mathrm{C}$, while little zircon would form at the cooler magmatic temperatures of 


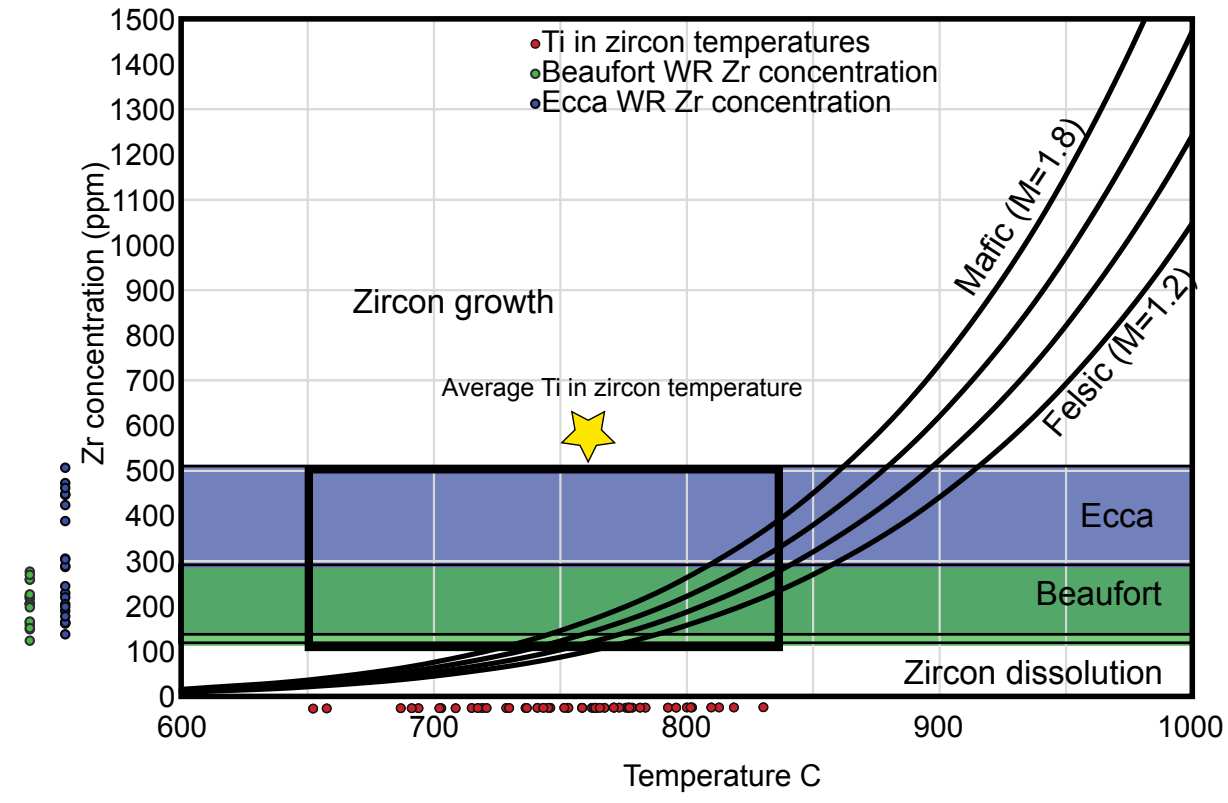

Figure 5: Ti-in-zircon and whole rock $\mathrm{Zr}$ concentrations (from McKay et al., in review) suggest that Beaufort Group tuffs were sourced from Zr-depleted, cooler magmas and may have been unable to generate coeruptive zircon resutling in increased inheritance.

$\sim 750^{\circ} \mathrm{C}$. Therefore, Beaufort Group tuffs would have been just at or well below Zr saturation levels. The observed Ti-in-zircon temperatures of $\sim 750^{\circ} \mathrm{C}$ from the entire Karoo Supergroup suite of tuffs is comparable with a mean temperature for "cold, inheritance-rich" magmas of $\sim 760^{\circ}$ C (Miller et al., 2003). Rapid magma generation and ascent would be required to prevent the dissolution and resorption of older, inherited zircon grains (Bea et al., 2007). This phenomenon would account for Beaufort Group tuffs containing grains that are significantly older than zircon in the underlying Ecca Group. Only larger, inherited grains would persist in Beaufort age melts, smaller, young grains either failing to grow or being consumed during Zr-poor magmatic pulses. The low zircon yields reported in Beaufort samples (McKay et al., 2015) further supports this hypothesis.

Discrepancies between SHRIMP and ID-TIMS ages have been resolved by other studies, albeit in rocks with drastically different zircon age populations. In the Humbolt Range, NV, Premo et al. (2008) resolved Cretaceous, 70-90 Ma igneous overgrowths on 1500 and 2200 Ma cores in an deformed monzogranite that was previously dated at 2500 Ma using ID-TIMS. Compston (2000) found multiple populations of U-Pb zircon ages via SHRIMP at 476, 450, 436, and 418 Ma. While ID-TIMS ages corroborate the older, $\sim 450$ and 476 Ma populations, Rb-Sr whole rock and K-Ar ages suggest late stage volcanism at $\sim 20 \mathrm{Ma}$ which is within error of the $\sim 417 \mathrm{Ma}$ populations, which made up $\sim 30 \%$ of zircon from the sampled tuffs, suggesting small $\mu \mathrm{m}$ scale zircon rims were analyzed via SHRIMP but would have been removed during pre-TIMS abrasion (Compston, 2000). Cathodoluminescence (CL) of Karoo tuff zircon (Fig. 1 and 6) show complex, oscillatory zoned zircon, which commonly have discontinuities between cores and irregular rim 
overgrowths (Fig. 6). These distinct breaks suggest periods of subdued zircon growth. CL imagery of zircon 14ZA116-2 (Fig. 6A) from an Upper Ecca tuff shows that the high uncertainty SHRIMP analysis of $243 \pm 10$ is fact mixed material between a low $U$ (bright) and low $U$ (dark) zone that are separated by an intra-grain discontinuity (red dashed line). TIMS analyses of the same grain also has a high uncertainty (for TIMS) of 2.31 m.y. These high uncertainties, along with CL images strongly suggest polyphase growth of zircon.

The Upper Ecca Group displays a significant population of SHRIMP 268 Ma zircon ages, with a large component ( 27 of 205 concordant analyses) of pre-Permian grains and a significant population of late Permian-early Triassic grains $(\mathrm{n}=53)$. A group of 88 grains forms a population of 267.9 $\pm 0.98 \mathrm{Ma}$ that coincides with the major peaks observed in LA-ICPMS and SHRIMP analyses (Fig. 2). Tuff 14ZA116, which contains a large population of 7 grains with a weighted mean of $268.5 \pm 0.1 \mathrm{Ma}(2 \sigma ; \mathrm{MSWD}=0.71)$ only contains 6 SHRIMP analyses (of 39) that are within $1 \sigma$ error of this age population, with 23/30 Permian-Triassic grains younger than, outside of $1 \sigma, 268.5 \mathrm{Ma}$. If cryptic $\mathrm{Pb}$-loss were responsible for the age discrepancies, a bell-shaped population centered at $\sim 268 \mathrm{Ma}$ would be expected, with minor Pb-loss and inheritance forming the outliers. Instead, Upper Ecca Group tuffs contain a distinct population of late Permian ( 252-257 Ma) grains, which are not likely due to $\mathrm{Pb}$-loss but may represent late Permian magmatic overgrowths on middle Permian zircon during subsequent magmatism. In addition to an abundance of Ordovician and older SHRIMP ages (McKay et al., 2015), the presence of 256.3, 262.5, and 267.6 Ma grains as determined by TIMS in Beaufort tuffs, with uncertainties $<0.5 \mathrm{~m}$.y. all but confirms zircon recycling in the Beaufort tuffs. The presence of Late Permian and Triassic detrital mica (246 and 228 Ma; Hälbich et al., 1983; 252-254 Ma; Arosio, 2012) and detrital zircon (52\% of PermianTriassic detrital zircon reported were $<268 \mathrm{Ma}$; Arosio, 2012) in the lower Beaufort stratigraphically approximate to sample 12ZA18, precludes a middle Permian (267.6 Ma) age for this strata, as suggested by CA-TIMS zircon geochronology. Detrital mica ages, however, may provide more reliable age constraints, since mica crystallization would be entirely independent from zircon recycling systematics. To further test this hypothesis, chemical abrasion (CA) SHRIMP analyses could be performed, however, CA-SHRIMP has been shown to possibly yield erroneously old results compared not only to CA-ID-TIMS but also Rb-Sr isochron ages (Kryza et al., 2014). Additional ${ }^{40} \mathrm{Ar} /{ }^{39} \mathrm{Ar}$ and $\mathrm{Rb}$-Sr whole rock ages, however should be impervious to the effects of crustal recycling/inheritance and Pb-loss and may unravel to complexity of zircon-based, Karoo chronostratigraphy. 


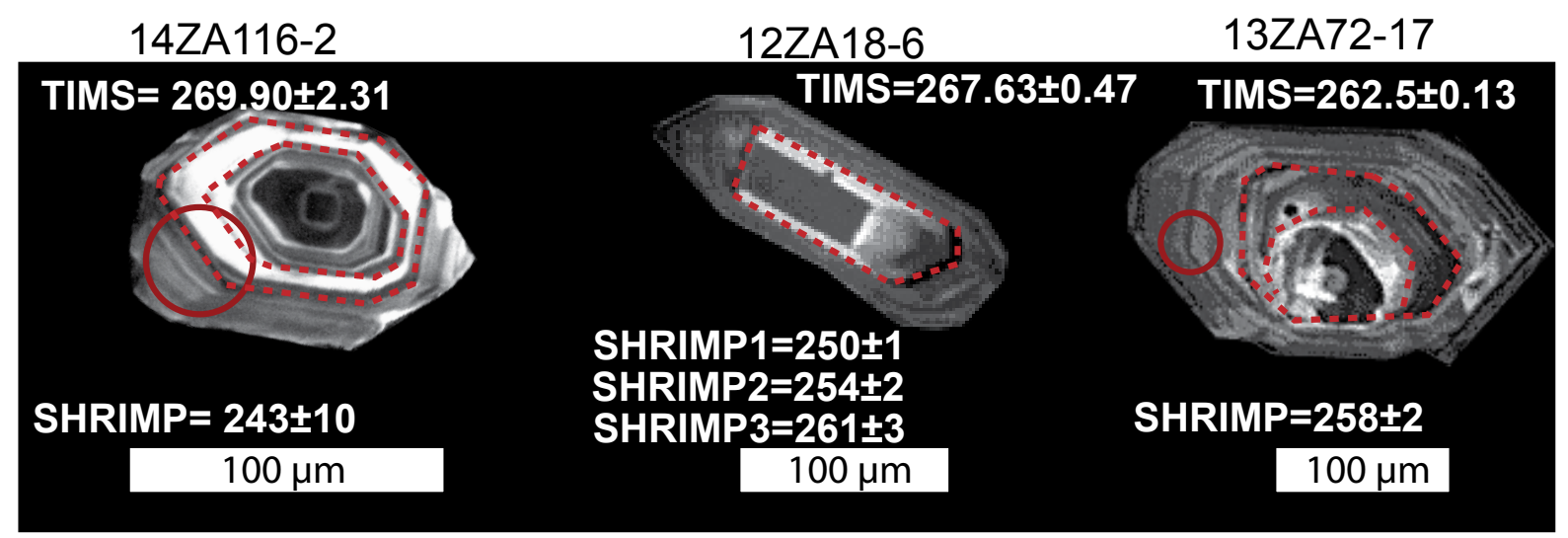

Figure 6: CL images, SHRIMP analyses (red circles), SHRIMP, and TIMS ages for selected zircon, with interpreted growth domains within the zircon grains (dashed red line). SHRIMP analyses from 12ZA18-6 are depth profiled ages and not visible in this CL.

\section{CONCLUSION}

Magmatic recycling, inheritance, and $\mathrm{Pb}$-loss in zircon populations can obscure geologically meaningful geochronology results. Since only grains selected for TIMS analyses were treated to remove $\mathrm{Pb}$-loss domains, younger ages that are exclusive to SHRIMP analyses and completely absent from LA-ICPMS and TIMS datasets suggest that the age discrepancies are controlled by spatial resolution and aliquot volume, with the SHRIMP analyses requiring the least amount of sample (by an order of magnitude) with the highest spatial resolution. By coupling CL imagery, microanalysis, with a characterization of the magmatic system, U-Pb zircon SHRIMP, LA-ICPMS, and TIMS ages record a story of significant crustal recycling and inheritance in the magmatic source of tuffs in the Karoo Supergroup, South Africa. Although cryptic Pb-loss cannot be ruled out, Tiin-zircon and $\mathrm{Zr}$ saturation temperatures suggest the magmatic source was near Zr-undersaturation during the late Permian and Early Triassic (McKay et al., in review). This evidence suggests that inheritance may have strongly influenced the $\mathrm{U}-\mathrm{Pb}$ age results.

\section{ACKNOWLEDGMENTS}

This work was partially funded by grants from the American Association of Petroleum Geologist, Society for Sedimentary Geology, and Geological Society of America to McKay, West Virginia University to McKay and Weislogel, and a cooperative agreement with the University of Manchester and University of Leeds through the SLOPE4 consortium. TIMS analyses were performed by Actlabs Canada. LA-ICPMS data were collected at the University of Arizona Laserchron lab. 


\section{REFERENCES}

Bea, F., Montero, P., González-Lodeiro, F., Talavera, C, (2007), Zircon inheritance reveals exceptionally fast crustal magma generation processes in Central Iberia during the CambroOrdovician, Journal of Petrology, vol. 48 (12), p. 2327-2339.

Belousova, E.A., Griffin, W.L., O’Reilly, S.Y., (2006), Zircon crystal morphology, trace element signatures and $\mathrm{Hf}$ isotope composition as a tool for petrogenetic modelling: Examples from Eastern Australian granitoids, Journal of Petrology, vol. 47 (2), p. 329-353.

Compston, W., (2000), Interpretation of SHRIMP and isotope dilution zircon ages for the Palaeozoic time-scale: II. Silurian to Devonian, Mineralogical Magazine, vol. 64 (6), p. 11271146.

Compston, W., Gallagher, K., (2012), New SHRIMP zircon ages from tuffs iwthin the British Palaeozoic stratotypes, Gondwana Research, vol. 21 (4), p. 719-727.

Condon, D.J., Schoene, B., McLean, N.M., Bowring, S.A., Parrish, R.R. (2015), Metrology and traceability of U-Pb isotope dilution geochronology (EARTHTIME Tracer Calibration Part I), Geochimica et Cosmochimica Acta, doi: 10.1016/j.gca.2015.05.026.

Goldich, S.S. and Fischer, L.B. (1986), Air abrasion experiments in U-Pb dating of zircon, Chemical Geology, vol. 58 (3), p. 195-215.

Harley, S.L., Kelly, N.M., Möller, A., (2007), Zircon behavior and the thermal histories of mountain chains, Elements, vol. 3, p. 25-30.

Hoskin, P.W.O., Schaltegger, U., (2003), The composition of zircon and igneous and metamorphic petrogenesis, Reviews in Mineralogy and Geochemistry, vol. 53, p. 27-62.

Kirkland, C.L., Smithies, R.H., Taylor, R.J.M., Evans, N., McDonald, B., (2015), Zircon $\mathrm{Th} / \mathrm{U}$ ratios in magmatic environs, Lithos, vol. 212-215, p. 397-414.

Kryza, R., Crowley, Q.G., Larionov, A., Pin, C., Oberc-Dziedzic, T., Mochnacka, K. (2012), Chemical abrasion applied to SHRIMP zircon geochronology: an example from the Variscan Karkonosze Granite (Sudetes, SW Poland), Gondwana Research, vol. 21 (4), p. 757-767.

Kryza, R., Pin, C., Oberc-Dziedzic, T., Crowley, Q.G., and Larionov,A., (2014), Deciphering the geochronology of a large granitoid pluton (Karkonosze Granite, SW Poland): an assessment of $\mathrm{U}-\mathrm{Pb}$ zircon SHRIMP and $\mathrm{Rb}-\mathrm{Sr}$ whole-rock dates relative to U-Pb zircon CA-ID-TIMS, International Geology Review, vol 56 (6), doi: 10.1080/00206814.2014.886364 
Lawton, T. F., (2014), Small grains, big rivers, continental concepts, Geology, vol. 42 (7), p. 639-640.

Mattinson, J.M., (2005), Zircon U-Pb chemical abrasion ("CA-TIMS”) method: Combined annealing and multi-step partial dissolution analysis for improved precision and accuracy of zircon ages, Chemical Geology, vol. 220, p. 47-66.

Millet, C.F., McDowell, S.M., Mapes, R.W., (2003), Hot and cold granites? Implications of zircon saturation temperatures and preservation of inherritance, Geology, vol. 31 (6), p. 529-532.

McKay, M.P., Coble, M.A., Hessler, A., Weislogel, A.L., Fildani, A., (in review), Petrogenesis and provenance of distal volcanic tuffs in the Permian-Triassic Karoo Basin, South Africa: A window into a dissected, magmatic province, Geosphere.

Parrish, R.P. and Noble, S.R. (2003), Zircon U-Th-Pb geochronology by isotope dilutionthermal ionization mass spectrometry (ID-TIMS), Reviews in Mineralogy and Geochemistry, vol. 53, p. 183-213.

Premo, W.R., Castiñeiras, P., Wooden, J.L., (2008), SHRIMP-RG U-Pb isotopic systematics of zircon from the Angel lake orthogniess, East Humbolt Range, Nevada: Is this really Archean crust?, Geosphere, vol 4 (6), p. 963-975.

Rubidge, B.S., Hancox, P.J., Cantuneanu, O., (2000), Squence analysis of the Ecca-Beaufort contact in the southern Karoo of South Africa, S. Africa Journal of Geology, vol. 103, p. 81-86.

Thomas., W.A. (2011), Detrital-zircon geochronology and sedimentary provenance, Lithosphere, vol. 3 (4), p. 304-308. 


\section{CHAPTER 4: STRUCTURAL AND MAGMATIC CONTROLS ON TURBIDITE SYSTEM DEVELOPMENT: KAROO BASIN, SOUTH AFRICA}

\section{ABSTRACT}

We investigate the relationship between tectonism and sedimentation by integrating 587 new $\mathrm{U}-\mathrm{Pb}$ detrital zircon analyses from 6 sandstones in the Karoo Basin with stratigraphic age controls from $590 \mathrm{U}-\mathrm{Pb}$ tuff zircon analyses from 23 volcanic tuffs. U-Pb detrital zircon from the Karoo Supergroup indicates that the source of the turbiditic, deltaic, and fluvial sediments was an active volcanic province, with lesser contribution from the nearby Cape Fold Belt. The depositional ages obtained from the turbidites of the Karoo Basin, based on U-Pb zircon tuff ages, and the published ages for Cape Fold Belt, suggest that influx of course clastic sediment is synchronous with deformation in the adjacent Cape Fold Belt during the Gondwanan Orogeny. Deformational age estimates from the Cape Fold Belt are comparable to age estimates for orogenic deformation and metamorphism around the southern margin of Gondwana, suggesting a wide-spread, synchronous, regional orogenic event. U-Pb zircon from volcanic suites in South Africa and South America coupled with $\mathrm{U}-\mathrm{Pb}$ zircon from midcrustal plutonic rocks indicate that peak magmatism occurs between deformation events and predates turbidite deposition. Along this convergent margin, turbidite sedimentation appears to coincide with a major deformational phase, while magmatism is out-of-phase with deformation and turbidite sedimentation. While structural development of the Cape Fold Belt likely controlled the entry point of sediment into the basin, the main control on the influx of clastic sediment into the Karoo Basin may be increased volcanism along the Gondwanan margin. The large volume of volcanic detritus suggest synchronous sediment routes into the basin that could by-pass the emerging Cape Fold Belt. Ejecta could be transported via atmospheric transport independently from aqueous transport pathways and continental drainage divides to the

To be submitted to Basin Research as: McKay, M.P., Fildani, A., Weislogel, A.L., Dean. J., Structural and magmatic controls on turbidite system development: Karoo Basin, South Africa 
leeward side of an orogenic belt. This easily eroded, volcanic-sourced sediment may have been focused along structures, controlling post-peak magmatic, syn-deformational turbidite deposition early in the basins history. Once erosion had removed the majority of air-fall ash material in the fold and thrust belt, sedimentation including increasing amounts of recycled orogen sediment.

\section{INTRODUCTION}

The Carboniferous-Jurassic Karoo Supergroup of southern Africa records shallowingupward, deep-water to continental sedimentation in a tectonically controlled Gondwanan basin. The deep-water strata of the Ecca Group contains fine-grained turbidite systems that have been heavily studied to develop models for turbidite system evolution and commonly serve as outcrop analogues for turbidite petroleum reservoir studies (Wickens and Bouma, 2000). The development of these turbidites has been suggested to be controlled by many factors, including increased erosion in response to tectonic uplift, climatic variation, and eustatic fluctuation (Bouma, 2000; Flint et al., 2011). We present volcanic and detrital U-Pb zircon age constraints for turbidite systems and marginal marine sediments in the Ecca Group, U-Pb detrital zircon ages, integrated with previously published geo-thermochronology from the Cape Fold Belt (South Africa), Patagonia (South America), and the Antarctic Peninsula to investigate the relationship between sedimentation, the Gondwanide Orogeny, and active magmatism. From these data we observe a temporal and spatial correlation between initiation of turbidite systems in the Karoo Basin and deformation in the Cape Fold Belt, as part of the Gondwanide Orogeny. While the Cape Fold Belt likely controlled sediment entry point into the basin, the dominance of volcanic sediment in the detrital zircon record requires far-fetched transport from the continent margin, through an emerging metamorphic hinterland and fold belt into the basin. Based on these data, we suggest that the initiation of turbiditic deposition in the Karoo Basin may have been controlled by increased volcanism and the ensuing deposition of easily eroded volcanic ash in addition to structural development of the Cape Fold Belt, thereby providing a model for transporting active margin sediments across an active deformation belt. 
Figure 1: Paleogeographic reconstruction of southern Gondwana (from McKay et al., 2015 and references therein) with margin-wide basins, fold and thrust belts, and magmatic provinces. Inset: Figure 2 Karoo Basin and Cape Fold Belt.

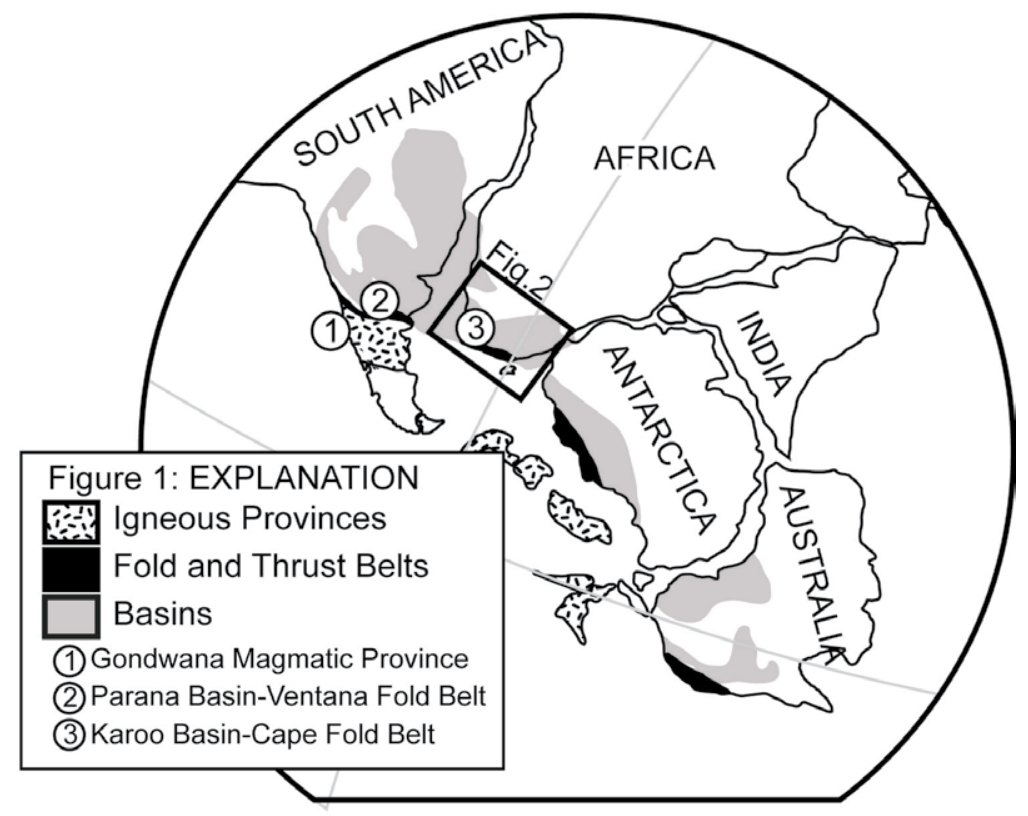

\section{GEOLOGIC BACKGROUND}

\subsection{Tectonic setting}

The Karoo Basin formed in response to Carboniferous-Triassic subduction along the active, Gondwanan margin (Veevers et al., 1994; Tankard et al., 2009), as part of a continent-wide foreland basin system (López-Gamundi and Rossello, 1998), extending across South America (Paraná and San Rafael basins), southern Africa (Karoo basins), Antarctica (Transantarctic basin), and Australia (Sydney basin) (Fig. 1). Basin subsidence was mechanically driven by a combination of orogenic, flexural loading driven by development of the Cape Fold Belt during the Gondwanide Orogeny (Cole, 1992; Catueanu et al., 1998) and epeirogenic, dynamic topography (Pysklywec and Mitrovica, 1999; Catuneanu et al., 2002; Tankard et al., 2009), which is typical of a retroarc foreland basin.

\subsection{Cape Fold Belt}

The Cape Fold Belt deformed Paleozoic-early Mesozoic strata during the Cape Orogeny, as part of the more extensive Gondwanide Orogeny, along the southern and southwestern margin of the Cape of Good Hope (Fig. 2). The fold belt is comprised of a north-south trend, the Cedarberg 


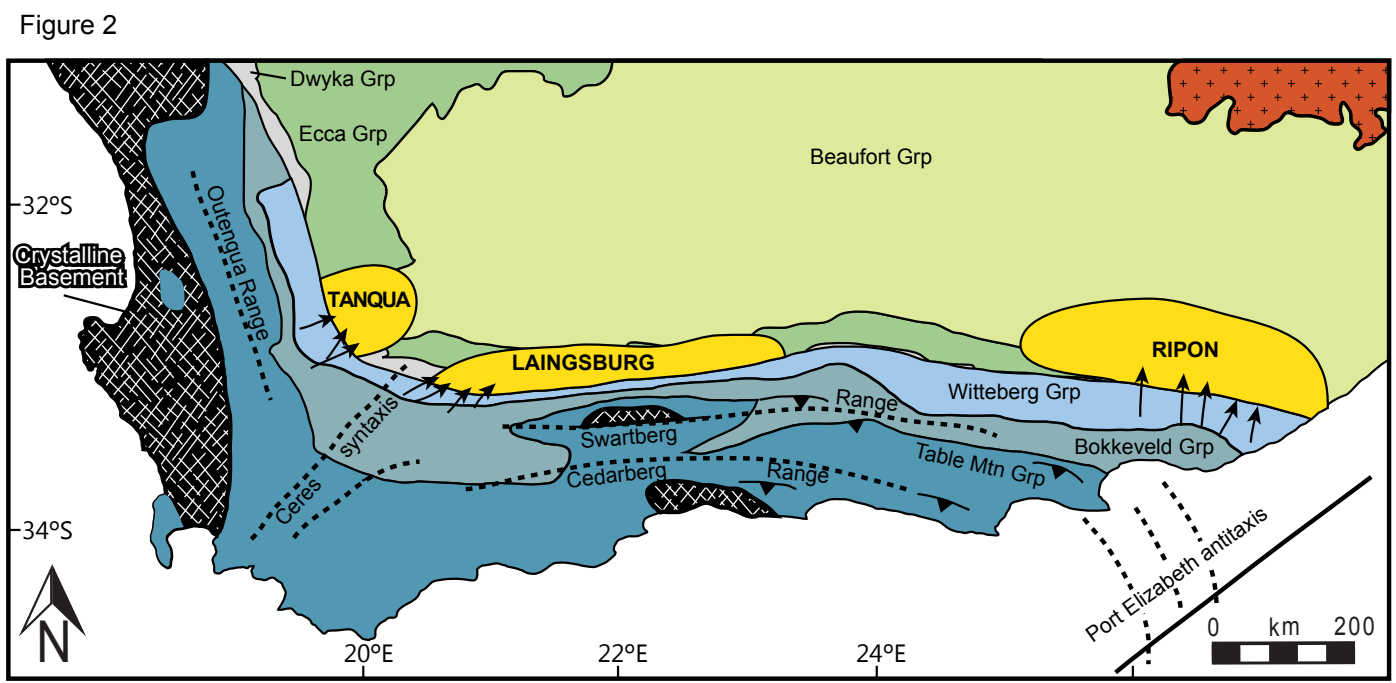

Figure 2: Schematic geologic map of South Africa with the Karoo Supergroup (greens; with turbidite depocenters in yellow), Cape Supergroup (blues and grays), crystalline basement, with generalized structural elements. After De. V. Wickens, 1992; Veevers et al., 1994; Johnston, 2002; Catuneanu et al., 2002.

arm, and an east-west trend represented by the Outinqua and Swartberg arms. The east-west and north-south trends converge into the Ceres/Cape syntaxis (synformal oroclinal bend), which is structurally manifest by a northeast plunging anticlinorium. Along the eastern coast of the Cape of Good Hope, the foldbelt takes a cryptic, antitaxial (antiformal oroclinal) bend near Port Elizabeth (Johnston, 2000). Cape Orogeny, part of the larger Gondwanide Orogeny, occurred in sporadic pulses with deformation in the Cape Fold belt focused at $\sim 278, \sim 259, \sim 247, \sim 230, \sim 215 \mathrm{Ma}$ (Hälbich et al., 1983). Basement exhumation was further constrained at $\sim 294, \sim 276, \sim 259, \sim 239, \sim 223 \mathrm{Ma}$ (Gresse et al., 1992), in the western Cape Fold Belt and 260 \pm 1 Ma in Cape Supergroup equivalents in eastern South Africa (Thomas et al., 1992). More recent age constraints on deformation pin the Cape Orogeny between 276-248 Ma (Hansma et al., in press). Correlative deformation belts in Patagonia and the Antarctic Peninsula also record deformation associated with the Cape/ Gondwanide Orogeny; comparing more robust age constraints from throughout western Gondwana to contentious age controls in South Africa may therefore provide insight into timing of the Cape Orogeny. Late Paleozoic-Early Mesozoic metamorphism and syndeformation magmatism are also recorded in the Antarctic Peninsula, and thought to be related to the Gondwanide Orogeny. The 

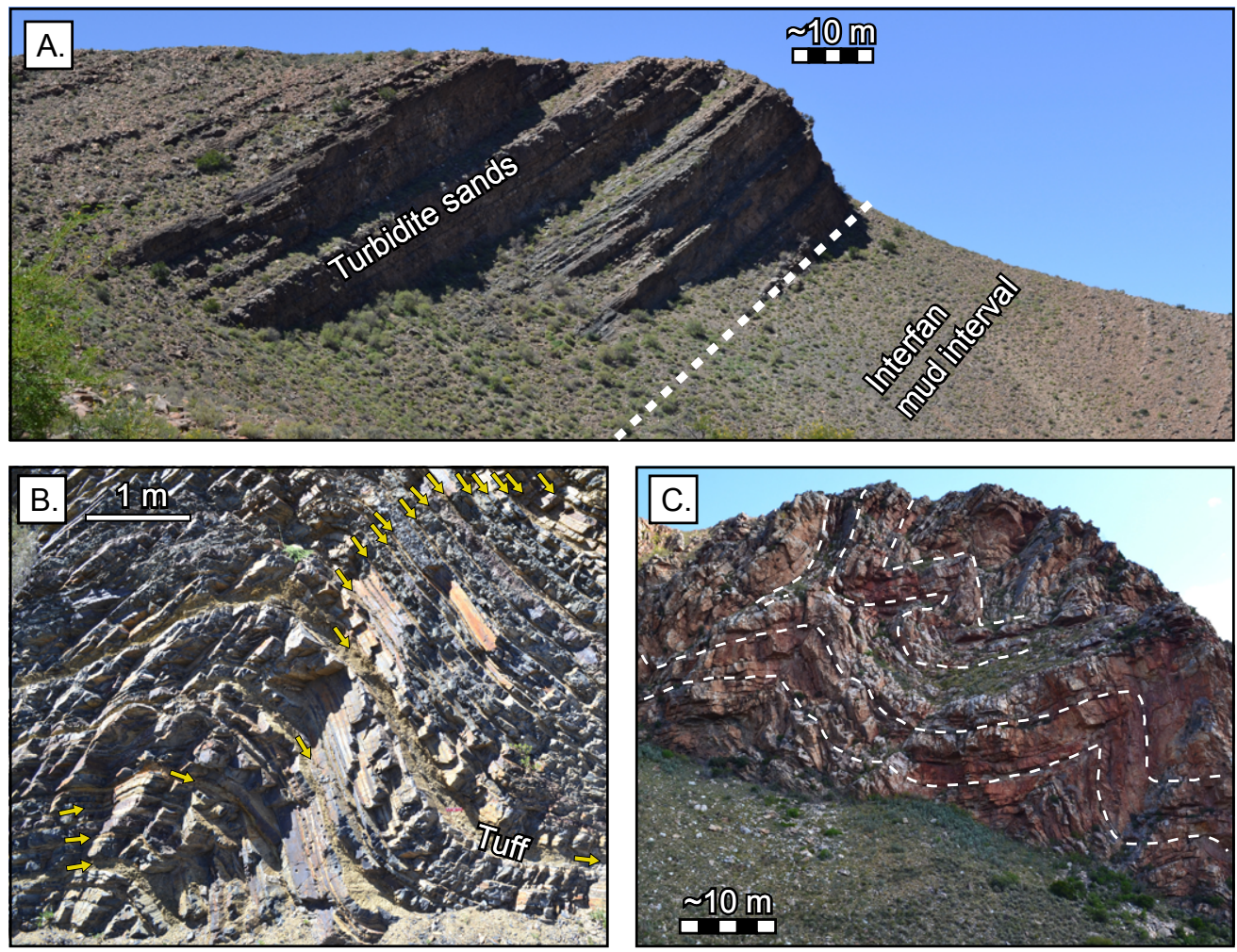

Figure 3: Outcrop photographs of (A.) turbidites within the Ecca Group in the Laingsburg subbasin, (B.) volcanic tuffs in the lower Ecca Group (tuffs marked with yellow arrows), (C.) chevron folds in quartzites within the Cape Fold Belt. Scales are approximate on A. \& C.

oldest event associated with the Gondwanide Orogeny in the Antarctic Peninsula is an $\mathrm{Rb} / \mathrm{Sr}$ whole rock age of $297 \pm 3$ Ma for a synmetamorphic pegmatite (Milne, 1990). U-Pb zircon ages for high U, metamorphic zircon overgrowth recording $280 \mathrm{Ma}$ (Riley et al., 2012), 258 Ma (258 $\pm 5 \mathrm{Ma}$,

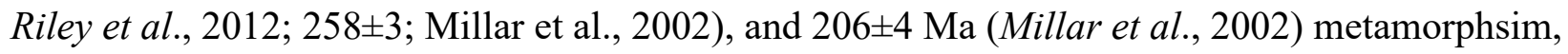
providing direct age controls for the Gondwanide Orogeny. Syndeformational plutons were also emplaced at $272 \pm 2$ and $255 \pm 5$ (Riley et al., 2012), further constraining the Gondwanide Orogeny. Granitic orthogneisses from the Antarctic Peninsula yielded hornblende K/Ar ages of $237 \pm 9$ and $243 \pm 10 \mathrm{Ma}(\operatorname{Rex}, 1976)$, that may represent exhumation and cooling. Ordovician plutons underwent migmatization around $\sim 228(229 \pm 3,227 \pm 1)$, further suggesting that the Gondwanide Orogeny persisted until at least the Mid-Triassic (Millar et al., 2002). Based on these age controls, deformation and metamorphism in the Antarctic Peninsula were active from 297-206 Ma, with pulses of deformation at 297, 278, 258, and $228 \mathrm{Ma}$, suggesting contemporaneous deformation throughout the western Gondwanan active margin. 


\subsection{Karoo Basin}

The basin fill of the Karoo Basin is the Karoo Supergroup, which is comprised of a flysch to mollase style, shallowing upward sequence. Deposition in the Permian-Jurassic Karoo Basin initiated with glacial sedimentation of the Dwyka Group of the Karoo Supergroup during the late Paleozoic Gondwanan glaciation and the subsequent glacial retreat (Veever et al., 1994; Bangert et al., 1999). Following ice retreat the marine Ecca Group was deposited in an already deepwater environment, suggesting initial subsidence of the basin predates deglaciation. The basal units of the Ecca Group are deepwater mudstones of the Prince Albert, Whitehill, and Collingham Formations that are ubiquitous across the southern Karoo basin, with minor thinning of the Whitehill and Collingham formations over the Ceres syntaxis of the Cape Fold Belt (de Beer, 1992; Scott et al., 2000), suggested syntectonic deposition. Above the Collingham Formation, lithostratigraphic successions within the Ecca Group are unique between three, distinct depocenters, the Tanqua, Laingsburg, and Ripon depocenters along the southern basin. Sediment supply into the basin can be described by two phases, where deposition of the Ecca Group and lower Beaufort (Adelaide and Tarkastad subgroups) is dominated by lithic-rich sediment, where lithic components decrease and quartz components increase in the upper Beaufort (Johnson, 1991). The compositional immaturity of the Ecca and lower Beaufort was interpreted to reflect a transitional/dissected arc source, while the compositionally more mature upper Beaufort was likely sourced from the nearby Cape Supergroup (Johnson, 1991; Scott, 1999). This is atypical of a traditional foreland basin, where the dominate sediment source is the adjacent fold belt (Scott, 1997). Several explanations have been proposed to explain the lack of Cape Supergroup sediments within the Ecca and lower Beaufort, including a lack of subaerial exposure of the early Cape Fold Belt, decreased erosion of the Cape Fold Belt in response to an orogenic rainshadow (Scott, 1997), and absence of the Cape Fold Belt during Ecca and lower Beaufort time (Tankard et al., 2009). Recent U-Pb detrital zircon from the Ecca and Beaufort Groups, however record a major population of Cape Supergroup sourced zircon within the Ecca Group, previously interpreted to be devoid of Cape Supergroup sediments (Vorster, 2013; Dean, 2014.), suggesting that the Cape Fold Belt was subaerial exposed 


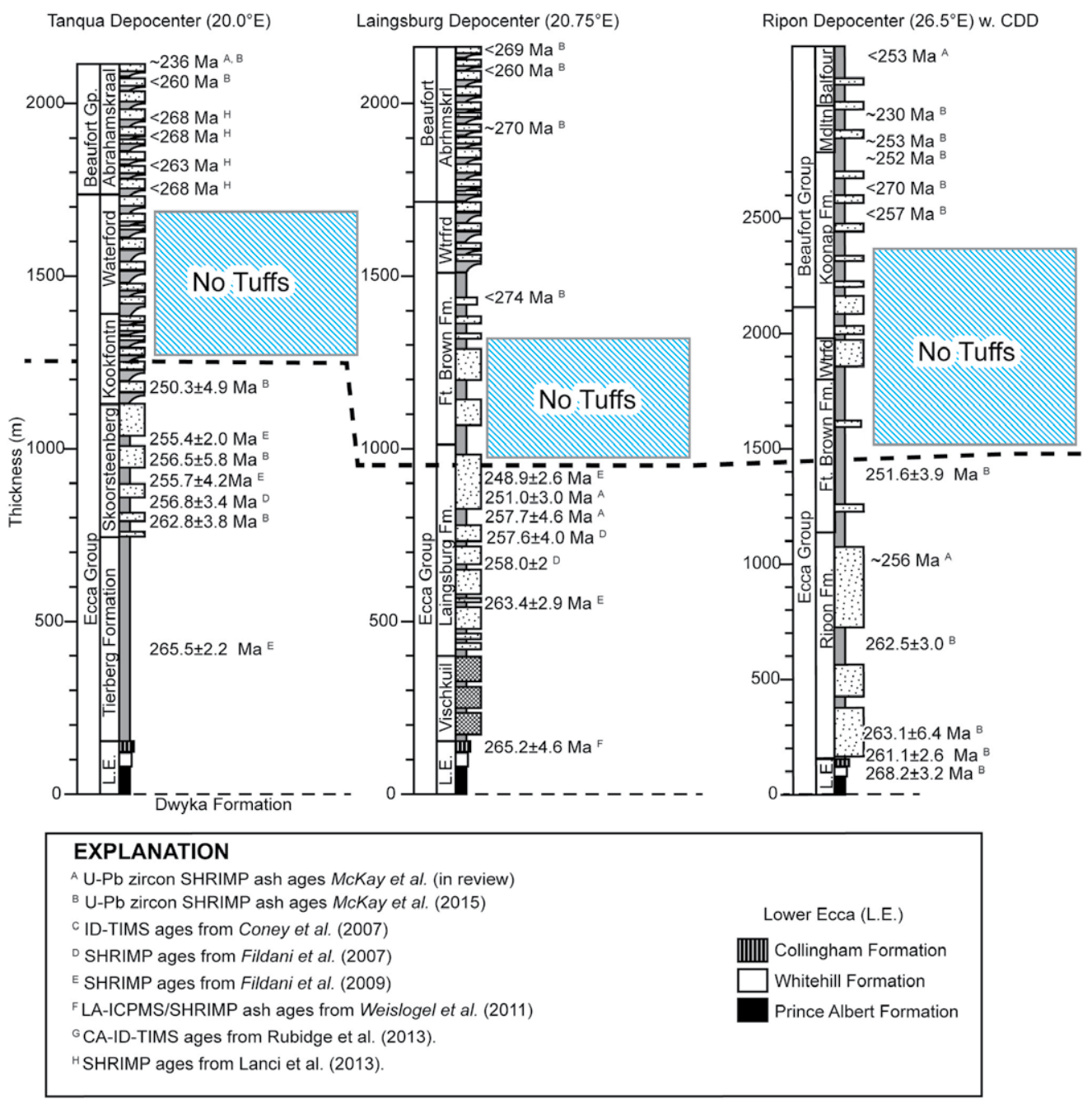

Figure 4: Chronostratigraphic ages from Fildani et al., 2007; 2009; Lanci et al., 2013; McKay et al., 2015; in press. A tuff free interval is denoted where no tuffs were found (McKay et al., 2015).

and eroded. This fold belt sourced material was then transported into the Karoo Basin, but diluted with an overwhelming influx of immature, active margin sediment, masking the compositional signal of the adjacent, compositionally mature fold belt.

\subsubsection{Tanqua Subbasin}

The Tanqua subbasin in the west contains undeformed, shallow dipping strata is bound by the Ceres syntaxis to the east and by the Cedarberg Range of the Cape Fold Belt to the west. The 
Collingham Formation is overlain by the mudstone dominated Tierberg Formation. Deposition of the Tierberg muds was followed by development of 5 distinct, very fine-to-fine grained turbidite systems, defined as Fans 1-5 (Hodgson et al., 2006) within the Skoorsteenberg Formation, which is comprised of fine-grained sand turbidites and interfan mud sediments (Hodgson et al., 2006; Wild et al., 2009) which onlap onto the Ceres syntaxis to the southeast. Marginal marine and deltaic sediments of the Kookfontein and Waterford formations overly the Skoorsteenberg turbidites, followed by the conformable deposition of the fluvial Abrahamskraal Formation of the terrestrial Beaufort Group, representing the transition of the basin from underfilled to overfilled.

\subsubsection{Laingsburg Subbasin}

The Laingsburg subbasin in the southwest contains broad to tightly folded Karoo strata that are bound to the northwest by the Ceres syntaxis and to the south by the Swartberg Range of the Cape Fold Belt. The Collingham formation is overlain by mudstones and mass-transport complexes within the Vischkail formation. The Vischkail formation is overlain by multiple very fine-to-fine grained turbidite systems, defined as Fans A-G (Flint et al., 2011) within the Laingsburg and Fort Brown formations, which are comprised of fine-grained sand turbidites and interfan mud sediments (Sixsmith et al., 2004) which onlap onto the Ceres syntaxis to the northwest. Transition from marine to terrestrial occurs in the overlying marginal marine and deltaic sediments of the Waterford formation and fluvial Abrahamskraal Formation of the terrestrial Beaufort Group.

\subsubsection{Ripon Subbasin}

In the Ripon subbasin, the stratigraphy of the lower Ecca Group is comparable to the Laingsburg and Tanqua subbasins, with the Dwyka Group overlain by the Prince Albert, overlying Whitehill, and ash-rich Collingham formations. The basal Ripon Formation is characterized by fine to medium grained turbidite fans with associated interfan muds. The first turbidite fan appears to have been deposited directly upon, perhaps unconformably, the Collingham (Veevers et al., 1994). The muds sequences observed above the lower Ecca Group in Tanqua and Laingsburg 
(Tierberg and Vischkail fms.) are distinctly absent from the Ripon area, which may suggest that Ripon turbidite systems developed prior to turbidite development in the western Karoo Basin (Catuneanu et al., 2002).

\subsection{Chronostratigraphic controls from $\mathrm{U}-\mathrm{Pb}$ zircon ash ages}

\subsubsection{Tanqua Subbasin}

$\mathrm{U}-\mathrm{Pb}$ zircon ages from tuffs in the Ecca Group within the Tanqua subbasin (Fig. 4) range from 267 to $250 \mathrm{Ma}$ (Fildani et al., 2007; 2009; Lanci et al., 2011; McKay et al., 2015) and young upward, suggesting that these ages may, at best, represent near-synchronous depositional ages of the tuffs, and by proxy the host strata. Above the younging upward series of tuffs in the Ecca Group lies a stratigraphic interval that does not contain any recognized volcanic tuffs that may correlate to a decrease in 250-241 Ma volcanism in Gondwana (Veevers, 2004; McKay et al., 2015). Airfall tuffs are again recognized above this interval in the Beaufort Group, although these ages are chaotic (McKay et al., 2015) and may relate to increased volcanic recycling (McKay et al., 2015), which can be observed in South American correlative volcanic deposits (Domeier et al., 2011). Ages in the Beaufort Group tuffs are, therefore considered maximum depositional ages, although one tuff contained 3 grains (McKay et al., 2015; McKay et al., in press) that are $236 \mathrm{Ma}$, which may form the most reliable age constraint for lower Beaufort deposition. This age is compatible with ${ }^{40} \mathrm{Ar} /{ }^{39} \mathrm{Ar}$ ages of detrital mica in the lower Beaufort Group of 250, 246, and $228 \mathrm{Ma}$ (Hälbich et al., 1983; Arosio, 2012), that suggests a Triassic age for the lower Beaufort Group.

\subsubsection{Laingsburg Subbasin}

Tuffs within the Ecca Group in the Laingsburg subbasin, similar to Tanqua subbasin, range from 265 to 249 Ma based on U-Pb zircon ages (Fildani et al., 2007; 2009; McKay et al., 2015). A tuff-free interval was also observed above a $\sim 249$ Ma tuff, which correlates to the tuff-free interval in the Tanqua subbasin. Above this interval U-Pb ages are $\sim 274-260 \mathrm{Ma}$ and contain increased number of older, xenocrystic grains, suggesting the age controls for the upper Ecca and Beaufort 

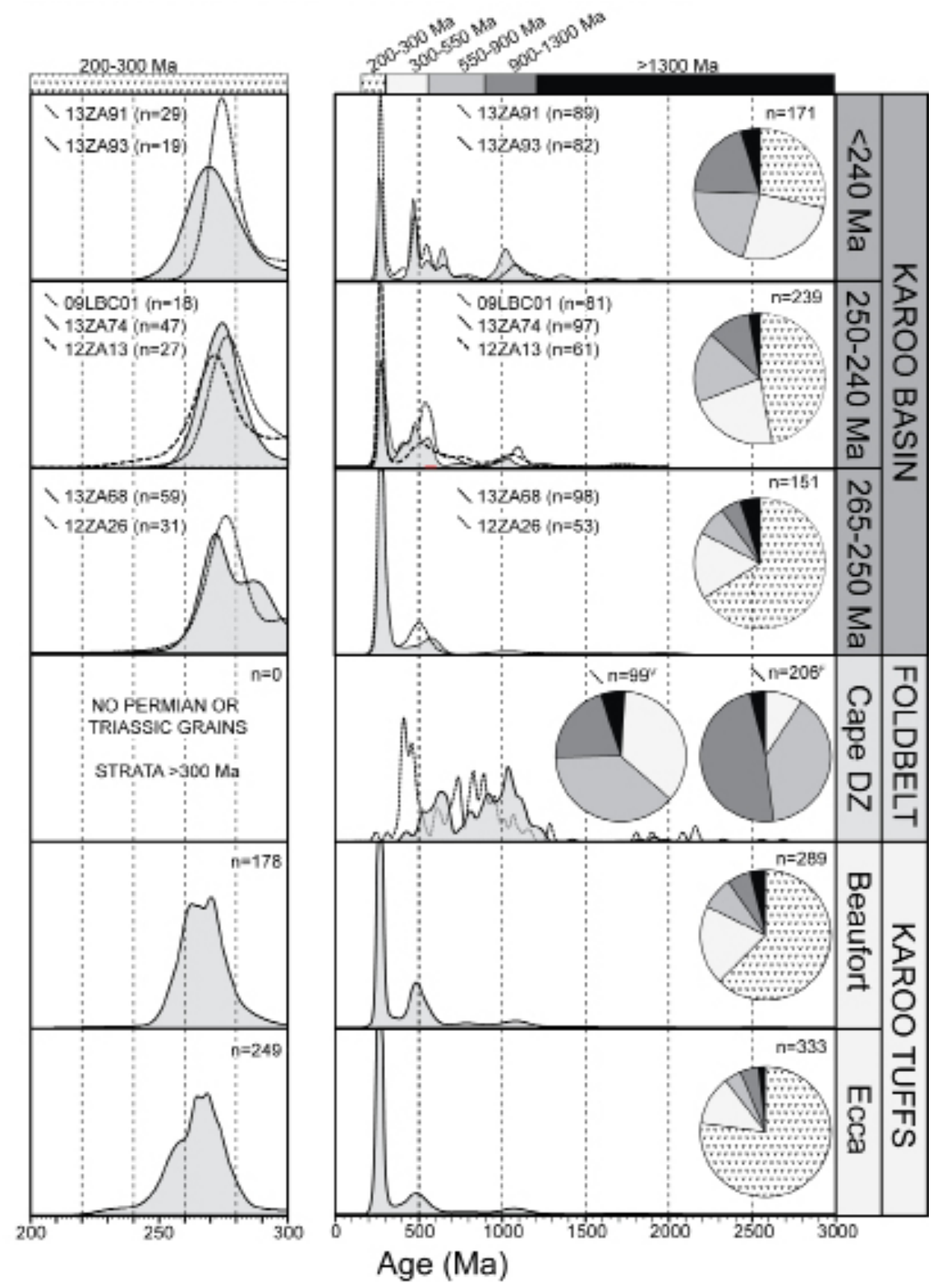

Figure 5. Kernel density estimate plots and pie charts for U-Pb detrital zircon ages for the (a) Beaufort Group sandstones $<240 \mathrm{Ma}$, (b) Waterford Formation and upper Ecca Group strata interpreted to be 240 250 Ma based on the location of the tuff gap, (c) Ecca Group strata below the tuff gap ( $>250 \mathrm{Ma})$, (d) the Cape Fold Belt, and $\mathrm{U}-\mathrm{Pb}$ zircon from tuffs in the (e) Beaufort and (f) Ecca Groups. There is an increase in Cape Fold Belt sourced zircon inversely proportional to a decrease in volcanic sourced grains through time/up-section. Zircons $<300$ Ma are dominantly $\sim 270 \quad \mathrm{Ma}$ in age, coincident with a peak in volcanism in southern Gondwana.

groups should be considered maximum depositional ages, while tuffs below the tuff gap contain more coherent zircon populations, which are more indicative of representing depositional ages of the host strata.

\subsubsection{Ripon Subbasin}

Ecca Group deposition in the Ripon subbasin is between $\sim 269$ Ma and 251 Ma. The lowest age constraints from the Ecca Group are from the Ripon Subbasin and include ages from the interbedded tuffs and mudstones of the Collingham Formation and range from 268-262 Ma. 


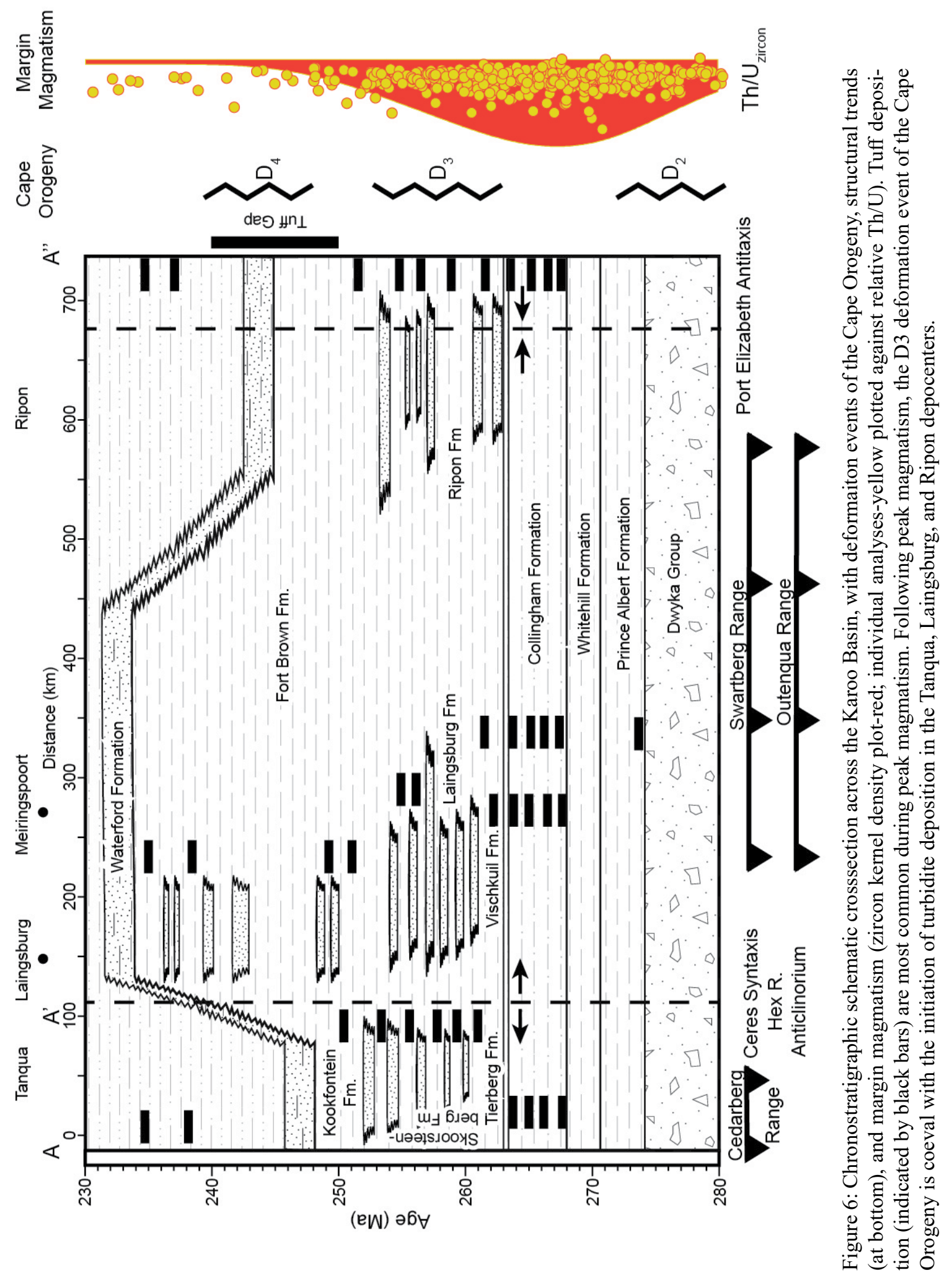


Turbidite deposition in the Ripon subbasin appears to be coeval with turbidite deposition elsewhere in the Karoo basin and began $\sim 262 \mathrm{Ma}$ and continued through $\sim 251 \mathrm{Ma}$. Above $251 \mathrm{Ma}$ strata, a tuff gap is present. Above this gap, recycled zircon ages are present, although Triassic ages ( 235 , $223 \mathrm{Ma}$ ) were obtained from 2 , low common $\mathrm{Pb}$, low $\mathrm{U}$, depth profiled analyses on grains from the upper Koonap Formation.

\section{Discussion}

\subsection{Sediment source for the Karoo turbidites}

The source of the Karoo turbidite sediment may hold clues as to the genetic history and influence of tectonism on the submarine fan systems as well as offer insights on the evolution of the Gondwanan margin. Sandstone petrography reveals that the Ecca Group and lower Beaufort Group are significantly rich in lithics compared to the Cape Fold Belt (Johnson, 1991) and include heavy minerals such as garnet, biotite, and tourmaline, which suggests that sediment was supplied from both the active margin magmatic province and the Gondwanide fold-thrust belt (i., 2003). $\mathrm{Sm}-\mathrm{Nd}$ isotopic analysis (Nd model ages and $\varepsilon_{\mathrm{Nd}}$ values; Andersson et al., 2003) also suggest a mixed provenance between juvenile, Permian sediment and older, Paleozoic, Proterozoic, and Archean sediment sources. Detrital zircon U-Pb ages from submarine fans within the Laingsburg and Ripon formations corroborate this model, with $\sim 25-65 \%$ of zircon populations consisting of Carboniferous-Triassic grains, likely from margin volcanic sources, and $35-75 \%$ of zircon representing recycling of pre-Carboniferous material, likely from the erosion of Paleozoic strata exposed during the Cape/Gondwanide Orogeny (Vorster, 2013; Dean, 2014). While the percentage of zircon should not be confused as a proxy for relative proportions of sediment from each source (Moecher and Samson, 2006), these data suggest that A) the Cape Fold Belt/Gondwanide foldbelt was subaerially exposed and constituted a significant sediment source for the Karoo turbidites,

and B) large volumes of volcanic sediment were capable of being transported from the margin to the basin. Previous work has suggested that the abundance of volcanoclastic sediments requires a sediment transport pathway through the Cape Fold Belt (Scott et al., 2000). However, volcanic 
grains are, by nature, explosively erupted, allowing transport over topographic features. Western Cordillera U.S. volcanic grains have been observed in modern Gulf of Mexico strata, even though they must have been sourced from west of the US continental divide (Fildani et al., in prep). Therefore, the provenance of volcanic grains is not restrained by aqueous transport and does not require sediment transport pathways. The volcanic grains observed in the Karoo basin may have been erupted, transported, and deposited on the emerging Cape Fold Belt. These easily erodable volcanic sediments would then be preferentially swept into the basin. The abundance of volcanic tuffs in the lower Ecca ( 270-265 Ma) and an increase in volcanic zircon 270-260 Ma (Fig. 6) confirms increased just prior to turbidite deposition in the Karoo basin. The evolution of Karoo sediments from (A) Permian, volcanic margin dominated to (B) Permian-Triassic, fold belt dominated may be, in part, related to the flushing of 270-260 Ma grains out of the early Cape Fold Belt in late Permian turbidites. Volcanic grains in later fluvial deposition may be recycled from earlier $>260$ Ma volcanic sediments, with increased proportions of Cape Supergroup-sourced sediments.

The relationship between deformation and sedimentation has been previously explored, but without absolute age controls for the Karoo strata. The strata below (Whitehill \& Collingham formations; de Beer, 1990; 1992) and above (Waterford Fm; Wickens and Bouma, 2000) over the Ceres syntaxis suggests that syntaxial development persisted through multiple deformational phases, likely $\sim 276$ to post-245 Ma. The partitioning of the turbidite strata in both the Tanqua and Laingsburg subbasins by the syntaxis suggests major topographic relief that must have developed following after deposition of the underlying strata, and likely during the deposition of Karoo turbidite fans (Scott et al., 2000), which would coincide with the largest deformation event within the syntaxis. Based on this link with tectonism, turbidite initiation throughout the Karoo Basin has been suggested to be caused by: A) increase in sediment supply through orogenic uplift and erosion (Visser, 1992), B) increased basin subsidence and accommodation (Cole, 1992), C) increased paleoslope during deformation (Visser, 1992). Within the western basin, turbidites in the Tanqua and Laingsburg subbasins are partitioned by the Ceres syntaxis that bounds each subbasin 
to the southeast and northwest respectively, suggesting development of the turbidite fan systems is during or after initial deformation and uplift in the Cape Fold Belt (de Beer, 1992; Scott et al., 2000). At a much smaller scale, individual submarine fan deposition may have been controlled by Cape Fold Belt structural trends within the Laingsburg subbasin. Within the deformed Laingsburg strata, the areal extent of submarine fans along with the paleoflow trends and facies distribution suggest that subtle, emerging Cape Fold Belt structures created basin floor topography that routed fans within the basin (Sixsmith et al., 2004).

\subsection{Deformation and Sedimentation}

Scott (1997) suggested that immerging structures of the Cape Fold Belt may have acted as pathways for sediment into the subbasins based on the spatial relationship and paleoflow directions in the western Karoo Basin. This hypothesis would require a pathway 100's of km's in length, however volcanic transport could deposit large volumes of volcaniclastic sediment across a region. Since turbidite deposition is associated with oroclinal bends, it is possible that these structures may have acted to focus volcanic sediment that previously accumulated elsewhere in the foldbelt and hinterland (Fig. 2; 6). Furthermore, prior to development of the antitaxial and syntaxial structures, the foldbelt may have acted as a barrier to coarser sediment entering the basin.

If deformation is synchronous, each deformation phase may have resulted in different effects upon subsidence and sediment influx. The first deformation phase (D1 at 296 Ma or earlier?) would have resulted in crustal loading and subsidence in the Karoo basin prior to early Permian deglaciation of Gondwana. Additional subsidence would have occurred during the second orogenic episode (D2 at $276 \mathrm{Ma}$ ), which is roughly coeval with final retreat of Gondwanan glaciers, as recorded by initial Prince Albert formation deposition. Following D2, the Cape Fold Belt may have acted as a sediment barrier, restricting sediment influx to muds, as observed in the mudstones

of the Prince Albert, Whitehill, and Collingham formations. The earliest development of the Ceres 
syntaxis occurred in the form of minor deformation and uplift during this event, creating the basin floor topography recorded by minor thinning of the Whitehill and Collingham formations (de Beer, 1992; Scott et al., 2000). At the onset of the D3 event, the Ceres syntaxial and Port Elizabeth antitaxial bends in the Cape Fold Belt experienced major syndeformational metamorphism, recorded as pervasive development of cleavage mica and crystalline basement exhumation dated at $259 \mathrm{Ma}$ (Hälbich et al., 1983; Gresse et al., 1992). The initial development of turbidites in the Tanqua (263 Ma), Laingsburg ( 263 Ma), and Ripon ( 262 Ma) depocenters coincides with (or slightly predate, within error) this deformation event. The distribution of turbidites approximate to, and structurally confined by major oroclinal bends suggests that high sedimentation rates associated with turbidite development may in fact be related to sediment channeling and focusing instead of increased erosion associated with uplift or climatic factors, potentially representing a previously unexplored tectonic control on turbidite development.

Deformation associated with D4-D5 are indistinguishable based on age, and this period in the Cape Orogeny is dominated by thrust fault development within the Cape Fold Belt and folding of the Ecca and lower Beaufort Groups (Hälbich, 1992). The chaotic nature of ages for deformation in the Cape Fold Belt are echoed in the age constraints for the Gondwanide Orogeny in correlative deformation belts throughout Gondwana (Fig. 6), suggesting that the nature and timing of Triassic deformation associated with the Gondwanide Orogeny may be comparable along the Panthalassan margin, unlike Permian deformation that appears to be isolated to distinct events throughout Gondwana.

Even within the Permo-Triassic basins of Gondwana, deformation focusing and channeling may not be isolated. Oroclinal bends have been recognized elsewhere along the Gondwanide foldbelt, as have Permo-Triassic marine and lacustrine turbidite sequences. The Ventana Fold Belt in northern Argentina is a western correlative of the Cape Fold Belt and contains a syntaxis that may be the western edge of a crustal salient possibly controlled by inherited basement structure (Pangaro and Ramos, 2012). If oblique structure development did control turbidite system initiation 
in the Karoo Basin, it is likely that sediment influx into basins north of the Ventana Fold Belt would have also been controlled by syntaxial sediment focusing and channeling. Further studies, however, are required to test that hypothesis in the Sauce Grande, Cuyo, and Parana basins that are adjacent to the Ventana Fold Belt. Likewise, turbidites throughout Permo-Triassic Gondwanan basins may share a spatial and relationship with active structures in the adjacent deformation belts, which requires continued investigation.

\section{CONCLUSION}

Although there is significant error in age controls on sedimentation and deformation, a temporal relationship is apparent between deformation associated with the Gondwanide Orogeny and initiation of turbidite systems within the Karoo Basin. Based on the age controls of deformation early basin subsidence occurred in response to early deformation and crustal loading associated with the D1 event at 294 and D2 event at 276 Ma creating an underfilled foredeep. Turbidite systems development in the Tanqua, Laingsburg, and Ripon depocenters coincides with the D3 deformation event at $259 \mathrm{Ma}$, which is following a period of increased volcanism. Given the spatial relationships between the Tanqua and Laingsburg depocenters with the Ceres syntaxis and Ripon depocenter with the Port Elizabeth antitaxis, major development of oroclinal bends in the Gondwanide Fold Belt occurred during the $\sim 259$ Ma, D3 deformation, with the syntaxial/antitaxial strucures focusing and channeling sediment from the magmatic arc into the basin, with only minor detrital input from the emerging Cape Fold Belt. Increased volcanism 265 Ma would have dispersed large volumes of easily transportable volcanic material across the fold-belt and other hinterland areas. Therefore, the high sedimentation rates thought to control turbidite development may not have been directly linked to increased erosion of the adjacent orogenic belt, but instead may be a result of an increased volume of poorly lithified volcanic-source sediment focused by a structurally confined sediment pathway. This model is consistent with the minor presence of Cape Supergroup sediments in the marine Ecca Group of the Karoo Supergroup, the age constraints for deformation along the Panthanlassan margin of Gondwana, chronostratigraphic constraints 
on turbidite deposition, and field observations within the sedimentary strata. If applicable in other tectonically-influence foreland basins, our model predicts 1) early sedimentation may be dominated by organic-rich, deepwater mudstones and shales, with the fold belt acting as a barrier to coarse, clastic sediment, 2) increased volcanism may correlate to increased turbidite frequency, and 3) syndeformational turbidite deposition may record distinct deformational events, including oroclinal bend development, which may be difficult to constrain using traditional geo/thermochronology techniques. This demonstrates that the temporal and spatial extent of sedimentation might reveal a more complete tectonic history of adjacent tectonically active margins.

\section{ACKNOWLEDGEMENTS}

This project was funded in part by American Associate of Petroleum Geologists, Society for Sedimentary Geology (SEPM), and Geological Society of America awards to McKay, West Virginia University awards to McKay and Weislogel, and the SLOPE4 consortium, and international consortium externally funded by the petroleum industry and managed jointly by the University of Manchester and University of Leeds.

\section{REFERENCES}

Andersson, P.O.D., Johansson, A., Kumpulainen, R.A., (2003), Sm-Nd isotope evidence for the provenance of the Skoorsteenberg Formation, Karoo Supergroup, South Africa, Journal of African Earth Sciences, vol. 36 (3), p. 173-183.

Arosio, R., (2012), Detrital studies on the Abrahamskraal Fm. From the Karoo Basin and their implications for the uplift of the Cape Fold Belt, M.S. thesis, University of Western Australia, 74 p.

Bangert, B., Stollhofen, H., Lorenz, V., Armstrong, R., (1999), The geochronology and significance of ash-fall tuffs in the glaciogenic Carboniferous-Permian Dwyka Group of Namibia and South Africa, Journal of African Earth Sciences, vol. 29, p. 33-49.

Catuneanu, O., Hancox, P.J., Rubidge, B.S. (1998), Reciprocal flexural behavior and contrasting stratigraphies: a new basin development model for the Karoo retroarc foreland system, South Africa, Basin Research, 10, 417-439.

Catuneanu, O., Hancox, P.J., Cairncross, B., Rubidge, B.S. (2002), Foredeep submarine fans and forebulge deltas: orogenic off-loading in the underfilled Karoo Basin, Journal of African Earth Sciences, 35, 489-502.

Cole, D.I. (1992), Evolution and development of the Karoo Basin, in de Wit, M.J. and Ransome, I.G.D. (Eds.) Inversion Tectonics of the Cape Fold Belt, Karoo and Cretaceous Basins of Southern Africa, A.A. Balkema: Rotterdam. 
Daly, M.C., Lawrence, S.R., Kimun'a, D., Binga, M. (1991), Late Palaeozoic deformation in central Africa: a result of distant collision?, Nature, 350, 605-607.

De Beer, C.H., (1990), Simultaneous folding in the western and southern branches of the Cape Fold Belt, South African Journal of Geology, vol. 93 (4), p. 533-591.

De Beer, C.H., (1992), Structural evolution of the Cape Fold Belt syntaxis and its influence on syntectonic sedimentation in the SW Karoo Basin, in de Wit, M.J. and Ransome, I.G.D. (Eds.) Inversion Tectonics of the Cape Fold Belt, Karoo and Cretaceous Basins of Southern Africa, A.A. Balkema: Rotterdam.

Dean, J.R. (2014), U-Pb detrital zircon geochronology within the Cape Fold Belt/Karoo Basin system, M.S. thesis, West Virginia University, 180 p.

Dickinson, W.R. and Suczek, C.A. (1979), Plate tectonics and sandstone compositions, Am. Association of Petroleum Geologist Bulletin, vol. 63, 12, 2164-2182.

Domeier, M., Van der Voo, R., Tomezzoli, R.N., Tohver, E., Hendriks, B.W.H., Torsvik, T.H., Vizan, H., Dominguez, A., Support for an "A-type" Pangea reconstruction from high fidelity Late Permian and Early to Middle Triassic paleomagnetic data from Argentina, Journal of Geophysical Research, vol. 116, B12114, 26 p., doi:10.1029/2011JB008495

Fildani, A., Drinkwater, N.J., Weislogel, A., McHargue, T., Hodgson, D.M., Flint, S.S., (2007), Age controls on the Tanqua and Laingsburg deep-water systems: New insights on the evolution and sedimentary fill of the Karoo Basin, South Africa, J. Sediment. Res., v. 77, p. 901-908.

Fildani, A., Weislogel, A., Drinkwater, N.J., McHargue, T., Tankard, A., Wooden, J., Hodgson, D., Flint, S., (2009), U-Pb zircon ages from the southwestern Karoo Basin, South AfricaImplications for the Permian-Triassic boundary, Geology, v. 37, p. 719-722.

Fildani, A., McKay, M.P., Stockli, D., Clark, J., Dykstra, M., Stockli, L., Hessler, A.M., (in prep), The ancestral Mississippi River drainage archived in the deep water Gulf of Mexico: Detrital zircon thermochronology of the Late Wisconsin Mississippi deep-sea fan, Geology

Flint, S.S., Hodgson, D.M., Sprague, A.R., Brunt, R.L., Van der Merwe, W.C., Figueiredo, J., Prélate, A., Box, D., Di Celma, C., Kavanagh, J.P., (2011), Depositional architecture and sequence stratigraphy of the Karoo basin floor to shelf edge succession, Lainsgburg depocentre, South Africa, Marine and Petroleum Geology, vol, 28, p. 658-674.

Gresse, P.G., Theron, J.N., Fitch, F.J., Miller, J.A. (1992), Tectonic inversion and radiometric resetting of the basement in the Cape Fold Belt, in de Wit, M.J. and Ransome, I.G.D. (Eds.) Inversion Tectonics of the Cape Fold Belt, Karoo and Cretaceous Basins of Southern Africa, A.A. Balkema: Rotterdam.

Hälbich, I.W., Fitch, F.J., Miller, J.A. (1983), Dating the Cape Orogeny, Spec. Publ. geol. Soc. S. Afr., 12, p. 149-164.

Hälbich, I.W. (1992), The Cape Fold BBelt Orogeny: State of the art 1970s-1980s, in de Wit, M.J. and Ransome, I.G.D. (Eds.) Inversion Tectonics of the Cape Fold Belt, Karoo and Cretaceous Basins of Southern Africa, A.A. Balkema: Rotterdam.

Hansma, J., Tohver, E., Schrank, C., Jourdan, F., Adams, D., (in press), The timing of the Cape 
Orogeny: New 40Ar/39Ar age constraints on deformation and cooling of the Cape Fold Belt, South Africa, Gondwana Research,

Hodgson, D.M., Flint, S.S., Hodgetts, D., Drinkwater, N.J., Johannessen, E.P., Luthi, S.M., (2006), Stratigraphic evolution of fine-grained submarine fan systems, Tanqua depocenter, Karoo Basin, South Africa. Journal of Sedimentary Research, 76, 20-40.

Johnson, M.R., (1991), Sandstone petrography, provenance and plate tectonic setting in Gondwana context of the southeastern Cape-Karoo Basin, South African Journal of Geology, vol. 94, p. 137-154.

Johnston, S.T. (2000), The Cape Fold Belt and syntaxis and the rotated Falkland Islands: dextral transpressional tectonics along the southwest margin of Gondwana, J. of African Earth Sciences, 31, 1, 51-63.

Lanci, L., Tohver, E., Wilson, A., Flint, S., 2013, Upper Permian magnetic stratigraphy of the lower Beaufort Group, Karoo Basin, Earth and Planetary Science Letters, 375, 123-134.

Lawver, L.A., Gahagan, L.M., Coffin, M.F. (1992), The development of paleoseaways around Antarctica, The Antarctic Paleoenvironment: A perspective on global climate change, Antarctic Research Series, 56, 7-30.

López-Gamundí, O.R. and Rossello, E.A. (1998), Basin fill evolution and paleotectonic patterns along the Samfrau geosyncline: the Sauce Grande basin-Ventana foldbelt (Argentina) and Karoo basin-Cape foldbelt (South Africa) revisted, Geol. Rundsch., 86, 819-834.

McKay, M.P., Weislogel, A.L., Fildani, A., Brunt, R.L., Hodgson, D.M., Flint, S.S. (2015), U-Pb zircon tuff geochronology from the Karoo Basin, South Africa: implications of zircon recycling on stratigraphic age controls, International Geology Review, vol. 57 (4), p. 393 410.

McKay, M.P., Coble, M., Hessler, A., Weislogel, A.L., Fildani, A. (in review), Petrogenesis and provenance of distal volcanic tuffs in the Permian-Triassic Karoo Basin, South Africa: A window into a dissected, magmatic province, Geosphere.

McKay, M.P., Weislogel, A.L., Fildani, A. (in prep); TIMS, LA-ICPMS, and SHRIMP provide different ages for complex, polystage zircon: Inheritance of Pb-loss?, to be submitted to Terra Nova.

Millar, I.L., Pankhurst, R.J., Fanning, C.M., (2002), Basement chronology and the Antarctic Peninsula: recurrent magmatism and anataxis in the Palaeozoic Gondwana Margin, Journal of the Geological Society, London, 159, p. 145-158.

Moecher, D.P., Samson, S.D. (2006), Differential zircon fertility of source terranes and natural bias in the detrital zircon record: implications for sedimentary provenance analysis, Earth and Planetary Science Letters, 247, 252-266.

Pangaro, F., Ramos, V.A., (2012), Paleozoic crustal blocks of onshore and offshore central Argenita: New pieces of the southwestern Gondwana collage and their role in the accretion of Patagonia and the evolution of Mesozoic south Atlantic sedimentary basins, Marine and Petroleum Geology, vol. 37 (10), p. 162-183. 
Rex, D.C., (1976), Geochronology in relation to the stratigraphy of the Antarctic Peninsula, British Antarctic Survey Bulletin, vol. 32, p. 55-61.

Riley, T.R., Flowerdew, M.J., Whitehouse, M.J., 2012, U-Pb ion-microprobe zircon geochronology from the basement inliers of eastern Graham Land, Antarctic Peninsula, Journal of the Geological Society, London, 169, 381-393.

Rossello, E.A., Massabie, A.C., López-Gamundí, O.R., Cobbold, P.R., Gapais, D. (1998), Late Paleozoic transpression in Buenos Aires and northeast Patagonia ranges, Argentina, J. of S. Am. Earth Sciences, 10, 389-402.

Scott, E.D. (1997), Tectonics and sedimentation: the evolution, tectonic influences and correlation of the Tanqua and Laingsburg subbasins, southwest Karoo Basin, South Africa, Ph.D. dissertation, Louisiana State University, 225 p.

Scott, E.D., Bouma, A.H., Wickens, H.D. (2000), Influence of tectonics on submarine fan deposition, Tanqua and Laingsburg subbasins, South Africa, in A.H. Bouma \& C.G. Stone (eds.), Fine-grained turbidite systems, AAPG Memoir, 72, 47-56.

Sixsmith, P.J., Flint, S.S., Wickens, H. DeV., Johnson, S.D. (2004), Anatomy and stratigraphic development of a basin floor turbidite system in the Laingsburg Formation, main Karoo Basin, South Africa, Journal of Sedimentary Research, vol. 74 (2), p. 239-254.

Tankard, A., Welsink, H., Aukes, P., Newton, R., Stettler, E., 2009, Tectonic evolution of the Cape and Karoo basins of South Africa, Marine and Petroleum Geology, vol. 26, 1379-1412.

Thomas, R.J., Marshall, C.G.A., Du Plessis, A., Firth, F.J., Miller, J.A., Brunn, W., Watkeys, M.K. (1992), Geological studies in the southern Natal and Transkei: Implications for the Cape Orogen, in de Wit, M.J. \& Ransome, I.G.D., (eds), Inversion Tectonics of the Cape Fold Belt, Karoo and Cretaceous Basins of Southern Africa, Balkema: Rotterdam, 229-238 pp.

Veevers, J.J. (2004), Gondwanaland from 650-500 Ma assembly through 320 Ma merger in Pangae to 185-100 Ma breakup: supercontinental tectonics via stratigraphy and radiometric dating, Earth-Science Reviews, 68, 1-132.

Veevers, J.J., Cole, D.I., Cowan, E.J., (1994), Southern Africa: Karoo basin and Cape fold belt, in Veevers, J.J., Powell, C.McA., eds., Permian-Triassic Pangean Basins and Foldbelts along the Panthalassan Margin of Gondwanaland, G.S.A. Memoir, v. 184, 223-279.

Visser, J.N.J., (1992), Basin tectonics in southwestern Gondwana during the Carboniferous and Permian, in de Wit, M.J. and Ransome, I.G.D. (Eds.) Inversion Tectonics of the Cape Fold Belt, Karoo and Cretaceous Basins of Southern Africa, A.A. Balkema: Rotterdam.

Vorster, C. (2013), Laser ablation ICP-MS age determination of detrital zircon populations in the Phanerozoic Cape and Lower Karoo Supergroups (South Africa) and correlatives in Argentina, Ph.D. dissertation, University of Johannesburg, 648 p.

Weislogel, A.L., Brunt, R.L., Flint, S. Fildani, Al., Rothfuss, J. (2011), Constraints on deepwater sedimentation in the Karoo Basin, South Africa, form U-Pb Geochronology of ash interbeds, AAPG Search and Discovery Article \#90124.

Wickens, H.D., Bouma, A.H. (2000), The Tanqua fan complex, Karoo Basin, South Affrica: 
Outcrop analog for fine-grained, deepwater deposits, in eds. Bouma, A.H., Stone, C.G., AAPG Memoir 72, Fine-grained turbidite systems.

Wild, R., Flint, S.S., Hodgson, D.M., (2009), Stratigraphic evolution of the upper slope and shelf edge in the Karoo Basin, South Africa, Basin Research, vol. 21 (5), p. 502-527.

Ziegler, A.N., Scotese, C.R., Barrett, S.F. (1983), Mesozoic and Cenozoic paleogeographic maps, in Tidal Friction and the Earth's Rotation II, (Eds.) Brosche, P. and Sundermann, J., pp. 240-252, Springer-Verlag: New York. 


\section{SUMMARY}

$\mathrm{U}-\mathrm{Pb}$ zircon geochronology coupled with zircon and whole rock/tuff geochemistry from volcanic tuffs in the Karoo Basin provide insight into the tectonic history of southern Gondwana. While there is a discrepancy between age results from different geochronology techniques, new SHRIMP age controls challenge the interpretation of the Permian-Triassic boundary in the Karoo. Whole rock and zircon geochemistry suggest that these tuffs record a transition from subduction driven to extensional, back arc magmatism. Based on zircon geochemical correlations, the tuffs in South Africa were likely sourced from magmatism in or near western Antarctica. Increased eruptivity and deformation along the active margin of Gondwana may have influenced the development of turbidites which were sourced heavily from volcanic material. 


\author{
Matthew P. McKay \\ 3410 Royal Oak Circle \\ Northport, AL, 35473 \\ matthewpaulmckay@gmail.com 256-225-4722 \\ JULY 2015
}

\begin{abstract}
Tectonics • Field Geology • Geochronology • Petrology • Stratigraphy • Structure • Microanalysis EDUCATION
\end{abstract}

West Virginia University (WVU), Morgantown, WV

Fall 2011-December 2015

Doctor of Philosophy (Ph.D.), Geology, Advisor: Dr. Amy Weislogel

Cumulative WVU GPA: $4.00 \quad$ A.B.D.

Specialty: Tectonics, petrology, geochronology, volcanic stratigraphy, geochemistry, structural geology, volcanology

University of Alabama (UA), Tuscaloosa, AL

Jun 2007-Aug 2011

Master of Science (M.S.), Geology, Advisor: Dr. Harold H. Stowell

August 2011

Graduate GPA: 3.89

Metamorphic and igneous petrology, geochemistry, geochronology, structural geology

Bachelors of Science in Geology (B.S.G)

August 2009

Cumulative UA GPA: 3.69

Cumulative Major GPA: 3.759

\title{
PROFESSIONAL EXPERIENCE
}

Geological Survey of Alabama

October 2014-Present

Geologist-Geologic Investigations Division

National Cooperative Geologic Mapping Program-STATEMAP

Focus on Southern Appalachian Valley and Ridge \& Piedmont

Mineral resources

\section{External Research Internship:}

StatOil in residence at Univ. Texas at Austin w./ Dr. A Fildani and Dr. D. Stockli

Summer 2014

Zircon $\mathrm{U}-\mathrm{Pb}$ and $(\mathrm{U}-\mathrm{Th}) / \mathrm{He}$ geo/thermochronology as an advanced provenance tool

Tectonic controls on continental drainages: Gulf of Mexico, Eastern Canada, Pyranees

Laser-Ablation ICPMS Split Stream U-Pb and REE data collection technique

\section{Internships:}

Chevron Energy Technology Company-Hydrocarbon Charge Team

Summer 2013

Petroleum system modeling: West of Shetlands, offshore U.K.

Chevron Energy Technology Company-Hydrocarbon Charge Team

Summer 2012 Integrating seismic attributes, geochemistry, and basin modeling

\section{Teaching/Research experience:}

Research assistant, WVU

Spring 2013 to Fall 2014

Sedimentology \& Stratigraphy (GEOL311) lab instructor, WVU

Spring 2012, Spring 2013

Field Course (GEOL404) graduate instructor, WVU

Summer 2013

Planet Earth (GEOL102) lab instructor, WVU

Fall 2011, Spring 2012

Earth Through Time (GEOL102/104) lab instructor, WVU

Fall 2012, Spring 2013

Mineralogy (GEO210) lab instructor, UA

Fall 2009, Fall 2010 
Field Course (GEO495) graduate instructor, UA

Research assistant/isotope lab manager, UA

Undergraduate research assistant/field assistant, UA
Summer 2010

Spring 2010 \& 2011, Summer 2011

Spring 2008-Summer 2009

\section{AWARDS, GRANTS, AND PROFESSIONAL SERVICE}

AAPG Foundation U.S. Military Veterans Scholarship Committee Member

2015

Convener/Chair: Techniques in Geochronology \& Microanalysis (V33D, 34A, 41A)

A.G.U. 2014

Chesapeake Energy Fellow

2011-2012; 2013-2014

Session Chair: Contractional Tectonics and Fold-Thrust Belts

AAPG ACE Pittsburgh 2013

West. Virg. Univ. Milton T. \& Doris E. Heald Promising Researcher Award

2013

Society for Sedimentary Geology Foundation Research Grant recipient

2012-2013; 2013-2014

Richard W. Beardsley Research Grant recipient (A.A.P.G.)

2013-2014

SEPM Wilson Medal Selection Committee Member

2013

Geological Society of America Research Grant recipient

2012-2013

Arthur A. Meyerhoff Memorial Grant recipient (A.A.P.G.)

2012-2013

Graduate Student Recruitment Coordinator, W.V.U. Dept. of Geology and Geography

2012

Outstanding teaching award, Univ. Alabama Dept. of Geological Sciences

\section{PUBLICATIONS (1 published, 1 in review, 3 in final prep/coauthor review, and 3 in prep):}

- McKay, M.P., Weislogel, A.L., Fildani, A., Brunt, R., Hodgson, D., Flint, S. (2015), U-PB zircon tuff geochronology from the Karoo Basin, South Africa: implications of zircon recycling on stratigraphic age controls, International Geology Review, .

- McKay, M.P., Coble, M., Hessler, A.M.,Weislogel, A.L., Fildani, A. (in review), Petrogenesis and provenance of distal, airfall tuffs in the Permian-Triassic Karoo Basin, South Africa: a window into a dissected, magmatic province, Geosphere

-McKay, M.P. \& Jackson, W.T., Jr., (in final prep), Tectonic stress regime recorded in zircon geochemistry, Lithosphere.

-Fildani, A., McKay, M.P. , Stockli, D.F., Clark, J.D., Weislogel, A.L., Dykstra, M., Hessler, A.M., (in final prep/coauthor review) Insights into the ancient Mississippi drainage system from detrital zircons analyses of the modern Mississippi deep-sea fan, Geology.

- McKay, M.P., Stowell, H.H., Gray, K.D., Schwartz, J.J. (in coauthor review) Sm-Nd garnet, U-Pb zircon geochronology, and P-T paths from the Salmon R. suture zone, west-central Idaho: Constraining terrane accretion events?, Tectonics.

- McKay, M.P., Osborne, W.E., (in prep), Geology of the Howelton 7.5 minute quadrangle, Etowah County, Alabama, Geological Survey of Alabama 7.5 minute quadrangle series.

- McKay, M.P., Fildani, A., Weislogel, A., Dean, J. (in prep), Structural and magmatic controls on turbidite system development: Karoo Basin, South Africa, Basin Research.

- McKay, M.P., Weislogel, A., Fildani, A., (in prep) TIMS, LA-ICPMS, and SHRIMP provide different ages for complex, polystage zircon: Inheritance of Pb-loss?, Terra Nova. 


\section{TECHNICAL PRESENTATIONS:}

-McKay, M.P., Weislogel, A.L., Fildani, A. (2014), Permian-Triassic Magmatism Along the Southern Gondwana Margin: Correlating Proximal and Distal Volcanic Deposits, AGU 2014 Abstract \#27627.

•Fildani, A., McKay, M.P. , Stockli, D.F., Clark, J.D., Weislogel, A.L., Dykstra, M., Hessler, A.M., (2014), Insights into the ancient Mississippi drainage system from detrital zircons analyses of the modern Mississippi deep-sea fan, AGU 2014 Abstract \#24921.

- Clark, J.D., Stockli, D.F., McKay, M.P., Thomson, K., Puigdefabregas, C., Castelltort, S, Dykstra, M., Fildani, A. (2014), Using U-Pb Detrital Zircon to Identify Evolution of Sediment Drainage in the South Central Pyrenean Foreland Basin, Spain, AGU 2014 Abstract \#30546.

- Bollen, E. M., Stowell, H. H., Schwartz, J. J., McKay, M. P. (2014), New P-T Paths for Metamorphism of Amphibolite from the Salmon River Suture Zone, Idaho, GSA 2014 Abstract \# 249883.

- McKay, M.P., Weislogel, A.L., Fildani, A. (2014ª), Using zircon REE compositions to aid in U-Pb zircon volcanic ash age interpretation in the Karoo Supergroup of South Africa, Goldschmidt 2014.

- McKay, M.P. (2014 $)$, Sedimentary perspectives on orogenesis: magmatism and deformation recorded in the Karoo Basin, South Africa, GSA 2014 Penrose Conference: Linkages and feedbacks in orogenic processes - a conference honoring the career of Robert D. Hatcher, Jr., Ashville, NC.

- Weislogel, A.L., McKay, M.P., Dean, J., Fildani, A. (2013), Perspectives and perils of using U-Pb zircon geochronology to constrain stratigraphic age: lessons from the Permian-Triassic Karoo basin, South Africa, A.G.U. Fall Meeting 2013, abstract \#V13D-2646.

- McKay, M.P. (2013), Tectonic controls on turbidite distribution, Invited technical presentation given to: 1) Shell-Clastic Research Team, 2) Chevron-Clastic Stratigraphy R\&D, 3) Chevron-Energy Tech. Company Geosciences Division Technical Talk

- McKay, M.P., Dean, J., Weislogel, A.L. (2013), The impact of high precision age controls in basin modeling for tectonic studies: Karoo Basin, South Africa, 2013 AAPG ACE Presentation.

- McKay, M.P. (2012), Resolving tectonic subsidence from quantitative basin modeling: Karoo Basin, South Africa, AAPG Search and Discovery article \#90157.

- McKay, M.P., Weislogel, A.L., Dean, J., Fildani, A. (2012), Integrating burial history and isostatic models to evaluate tectonic subsidence models: Karoo Basin, South Africa, GSA Abstracts with Programs, 44 (7).

- Stowell, H.H., McKay, M.P., Schwartz, J.J., Gray, K.D. (2011), Loading and metamorphism within the Salmon River suture zone, west-central Idaho. GSA Abstracts with Programs, Vol. 43, No. 5.

- McKay, M.P., Weislogel, A.L., 4 others (2011ª), Evolution and petrogenesis of Gondwanan volcanism from ashes within the Ecca \& Beaufort Grps: Karoo Basin, S. Afr., A.G.U. Fall Meeting 2011, \#V31F-2597.

- McKay, M.P., Stowell, H.H., Schwartz, J.J. (2011 b), P-T-t paths from the Salmon River suture zone, west-central Idaho: Continental growth by arc accretion, GSA Abstracts with Programs, Vol. 43, No. 4, p. 76.

\section{Short Courses/Field Trips:}

GSA Penrose Field Conference: Linkages and feedbacks in orogenic processes 2014

Chevron ETC Turbidite Field Course: Karoo Basin, S. Africa (as a graduate instructor) 2012

UCLA-NSF Secondary Ion Probe Microanalysis Workshop $\quad 2012$

SEPM and UL-Lafayette 3-D seismic interpretation, Lafayette, La 2011 


\section{Short Courses/Field Trips (cont.):}

GSA Rocky Mtn/Cordilleran Meeting field trip, Evolution of the Blue Mtns, OR and ID 2011 AAPG Imperial Barrel Award workshop, San Antonio, TX 2010

GSA Annual Meeting field trip, Transect through the Salmon River suture zone, Idaho 2009

\section{Selected Field Experience/Study Areas:}

Appalachian Mountains

Geol. Survey of Alabama

South Africa (western Gondwana remnants)

WVU Ph.D. research

Western Cordillera

Idaho, Oregon, Washington

Univ. of Ala. M.S. research, field assistant

New Mexico and Colorado

South Dakota and Montana

Univ. of Ala. field course graduate instructor

WVU field course graduate instructor

Atlantic Canada and Liberia

West of Shetlands and North Sea

Gulf of Mexico, Atl. Canada, Pyrenees

Chevron, seismic attribute analysis, basin modeling

Chevron, petroleum exploration, basin modeling

StatOil, detrital geochronology for provenance

\section{RESEARCH:}

Ph.D. (2011-Present), West Virginia Univ.: Geochronology and petrogenesis of volcanic tuffs from the Karoo Basin, South Africa: Implications on basin evolution, Gondwanan magmatism, and deformation

- Secondary Ion Microprobe (SIMS/SHRIMP) U-Pb zircon geochronology of ashes used for age controls

- Geochronology-defined Permian-Triassic boundary lies stratigraphically $>1 \mathrm{~km}$ below the biostratigraphically-defined P-Tr boundary (strata is $>10 \mathrm{~m}$.y. younger than thought).

- Zircon geochemistry used to interpret petrogenetic history of the Gondwanan margin

- Results demonstrate that REE composition can be used to identify subpopulations of zircon for data interpretation; may have implications on interpretation methods for ash geochronology.

- Chemical mapping using Electron Probe Microanalysis (EPMA) Wave-Length Dispersive (WDS) and Energy Dispersive (EDS) mapping/imaging of zircon grains has led to more precise $\mathrm{U}-\mathrm{Pb}$ analyses by elimating analysis of grains with potential $\mathrm{Pb}$-loss and focusing on chemical populations of interest.

- Karoo Basin Invited Petroleum Industry Presentations: Chevron Energy Technology Company, Chevron Clastic Stratigraphy R \& D Team, Shell Clastic Stratigraphy Research Group

M.S. (2009-2011), Univ. of Alabama: Constraining metamorphic events in a polydeformational, polymetamorphic accreted island-arc terrane, Salmon River Suture Zone, West Central Idaho.

- Integrated study: EPMA, X-ray Fluorescence (XRF) Spectrometry, Inductively Coupled Plasma Mass Spectrometry (ICPMS), Thermal Ionization Mass Spectrometry (TIMS) Sm-Nd geochronology, and field mapping/ surveying

- Results suggest thrust loading controls metamorphis pulses, not accretion events.

- Resolved long-lived orogenic events (>30 m.y.) associated with assembly of the western Laurentia. 
PROFESSIONAL MEMBERSHIPS:

Geological Society of America

American Association of Petroleum Geologists

Society for Sedimentary Geology (SEPM)

American Geophysical Union

Mineralogical Society of America

Deep Time Institute, Board Member

Alabama Geological Society

\section{CERTIFICATIONS AND TRAINING}

National Association of Underwater Instructors (NAUI) Certified Scuba Diver (Open Water)

High Ropes Course/Repelling/Mountaineering experience

\section{MILITARY OPERATIONS/LOGISTICS/MANAGEMENT}

During a four-year enlistment (May 2003-May 2007) in the United States Coast Guard I honorably attained the rank of Petty Officer Second-Class (E-5) in the Yeoman rating. Duties as an active duty NCO included:

- Deck Seaman (E-3), USCGC Decisive (Aug. 2003-Mar. 2004); Duties/qualifications included: deck, heavy machinery \& small boat operation/maintenance, damage control \& weapons qualified, helm/lookout, quartermaster, battle medic.

- Yeoman (E-4; E-5), PSC Topeka (April 2004-May 2007); Auditor; Travel Support Team Assistant Team Leader, meritorious service supporting personnel throughout the field, fleet, and in-theatre operations.

Selected Awards \& Commendations (individual awards in BOLD):

- $\quad$ Armed Forces Service Medal for meritorious service during Hurricane Katrina response

- Commandants Letter of Commendation for outstanding performance of duty

- $\quad$ Presidential Unit Citation for Hurricane Katrina preparation, response, and recovery

- Good Conduct Medal • Meritorious Unit Citation-Operations

- $\quad$ Coast Guard “E” Ribbon

- $\quad$ Pistol Marksmanship

- Global War on Terrorism Medal _ National Defense Medal

\section{REFERENCES}

Dr. Amy Weislogel, Assistant Professor, Ph.D. advisor (304) 293-6721

Dr. Andrea Fildani, collaborator

Dr. Harold Stowell, Professor, M.S. advisor

Christopher Wittman, CPA. Anadarko Energy, (U.S. Coast Guard 2005-2007)
West Virginia University amy.weislogel@mail.wvu.edu

StatOil_afildani@gmail.com
hstowell@geo.ua.edu Phone: (303) 8427575

Further References and Supporting Documentation Furnished Upon Request 


\section{Appendix A: UTM locations for samples}

\begin{tabular}{|c|c|c|c|}
\hline WGS1984 Datum & & $(\mathrm{E})$ & $(\mathrm{S})$ \\
\hline Sample ID & Zone & Easting & Northing \\
\hline 09LGC-01 & $34 \mathrm{H}$ & 499591 & 6321783 \\
\hline 09LGC-04 & $34 \mathrm{H}$ & 499614 & 6321821 \\
\hline 09LGV-01 & $34 \mathrm{H}$ & 499653 & 6321854 \\
\hline 09LGV-02 & $34 \mathrm{H}$ & 499631 & 6321986 \\
\hline 09LGV-04 & $34 \mathrm{H}$ & 499587 & 6322155 \\
\hline 09TВТ-01 & $34 \mathrm{~J}$ & 381726 & 6493248 \\
\hline 09ТВТ-04 & 34J & 382146 & 6494390 \\
\hline 12ZA05B & $34 \mathrm{H}$ & 468362 & 6339683 \\
\hline 12ZA07 & $34 \mathrm{H}$ & 405027 & 6393983 \\
\hline 12ZA08 & $34 \mathrm{H}$ & 404351 & 6394562 \\
\hline 12ZA10 & $34 \mathrm{H}$ & 404352 & 6349738 \\
\hline 12ZA12 & $34 \mathrm{H}$ & 436541 & 6414097 \\
\hline 12ZA16 & $34 \mathrm{H}$ & 438007 & 6414177 \\
\hline 12ZA18 & $34 \mathrm{H}$ & 443935 & 6419135 \\
\hline 12ZA19 & $34 \mathrm{H}$ & 643534 & 6333624 \\
\hline 12ZA22A\&B & $34 \mathrm{H}$ & 643542 & 6334491 \\
\hline 12ZA23 & $34 \mathrm{H}$ & 643558 & 6334551 \\
\hline 12ZA45 & $35 \mathrm{H}$ & 467444 & 6345581 \\
\hline $12 \mathrm{ZA} 46$ & $35 \mathrm{H}$ & 466973 & 6345303 \\
\hline 12ZA54 & $35 \mathrm{H}$ & 465066 & 6324815 \\
\hline 12ZA55 & $35 \mathrm{H}$ & 465184 & 6324766 \\
\hline 12ZA60 & $35 \mathrm{H}$ & 464923 & 6325655 \\
\hline 12ZA61 & $35 \mathrm{H}$ & 463796 & 6328315 \\
\hline 13ZA67 & $35 \mathrm{H}$ & 464802 & 6325212 \\
\hline 13ZA72A & $35 \mathrm{H}$ & 465441 & 6361597 \\
\hline 13ZA75B & $35 \mathrm{H}$ & 466981 & 6345320 \\
\hline 13ZA76 & $35 \mathrm{H}$ & 467384 & 6345555 \\
\hline 13ZA77 & $35 \mathrm{H}$ & 463485 & 6335583 \\
\hline 13ZA78A & $35 \mathrm{H}$ & 464393 & 6327210 \\
\hline 13ZA79 & $35 \mathrm{H}$ & 464762 & 6325361 \\
\hline 13ZA93A & $34 \mathrm{H}$ & 456880 & 6397502 \\
\hline 14ZA116A & $34 \mathrm{H}$ & 498466 & 6322788 \\
\hline 14ZA121 & $34 \mathrm{H}$ & 461573 & 6331369 \\
\hline 14ZA128A & $34 \mathrm{H}$ & 443811 & 6418968 \\
\hline 14ZA129A & $34 \mathrm{H}$ & 568541 & 6447715 \\
\hline 14ZA130A & $34 \mathrm{H}$ & 560632 & 6428940 \\
\hline 14ZA141 & $34 \mathrm{H}$ & 373943 & 6266659 \\
\hline 14ZA142 & $34 \mathrm{H}$ & 373774 & 6265469 \\
\hline 14ZA154 & $35 \mathrm{H}$ & 464299 & 6326517 \\
\hline 14ZA161A & $35 \mathrm{H}$ & 484158 & 6404712 \\
\hline 14ZA162A & $35 \mathrm{H}$ & 481244 & 6401608 \\
\hline 14ZA168A & $35 \mathrm{H}$ & 271276 & 6441037 \\
\hline BLOUKRANS & $34 \mathrm{H}$ & 492420 & 6343593 \\
\hline SUTHER & $34 \mathrm{H}$ & 465375 & 6412116 \\
\hline
\end{tabular}




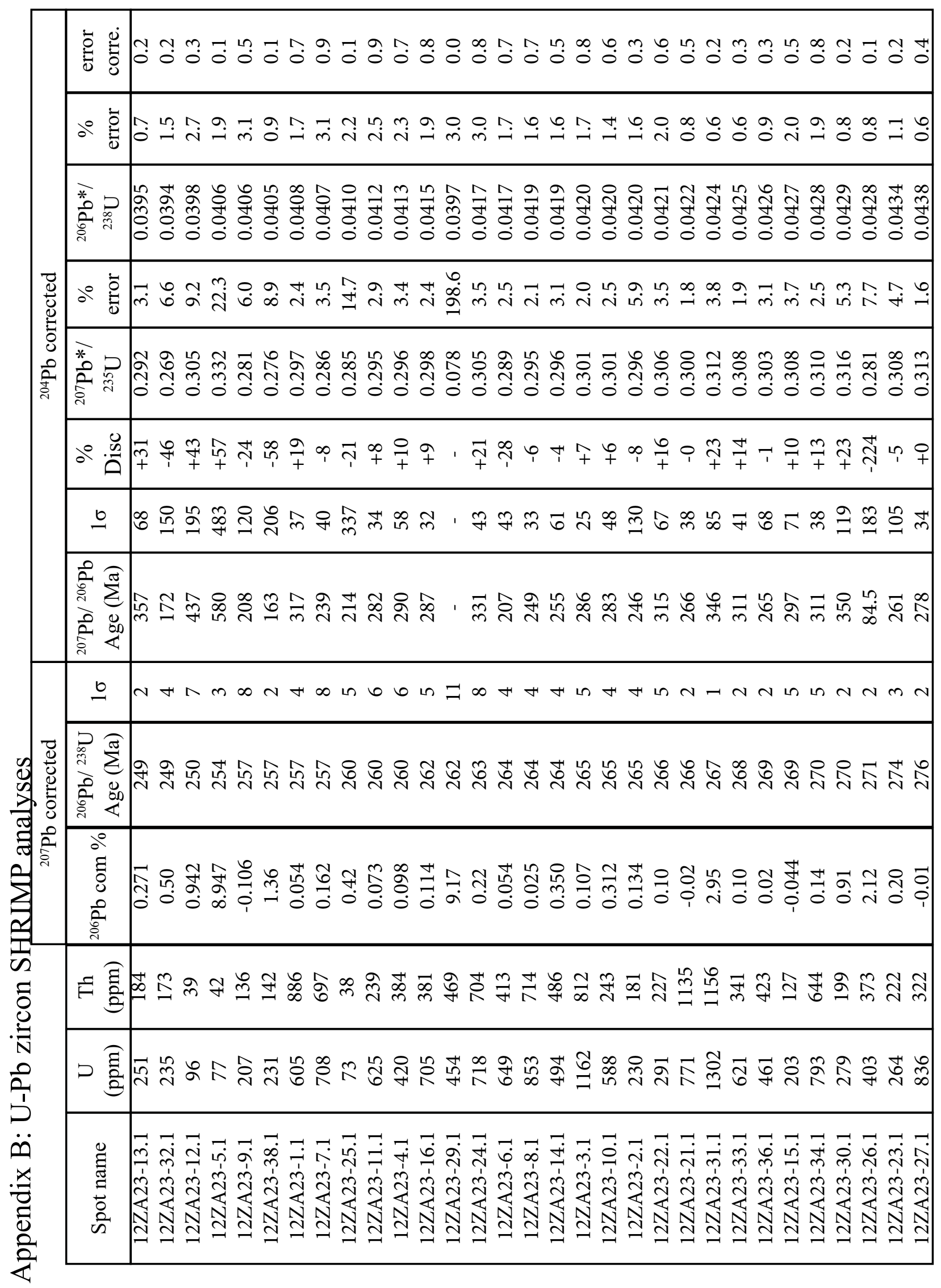




\begin{tabular}{|c|c|c|c|c|}
\hline \multirow{8}{*}{ 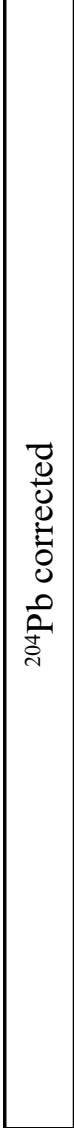 } & 害晜 & 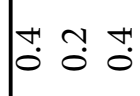 & H: & 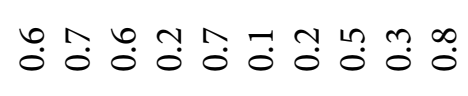 \\
\hline & 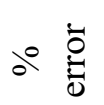 & $\exists a$. & 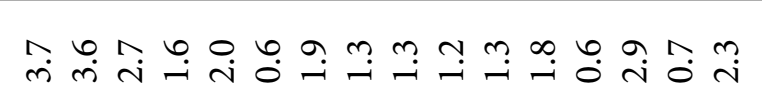 & 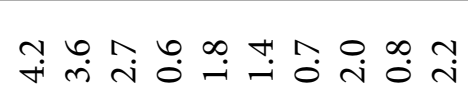 \\
\hline & 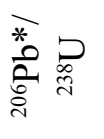 & 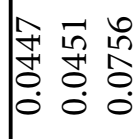 & 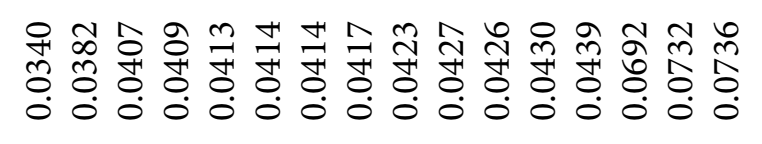 & 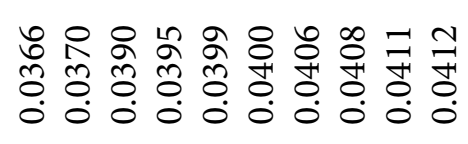 \\
\hline & $\therefore \circ$ & $\ln \begin{array}{ll}n \\
\text { in }\end{array}$ & 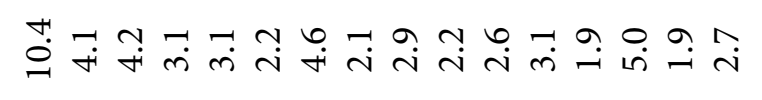 & 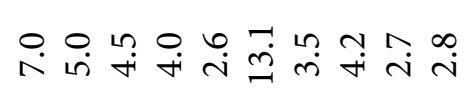 \\
\hline & D & 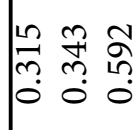 & 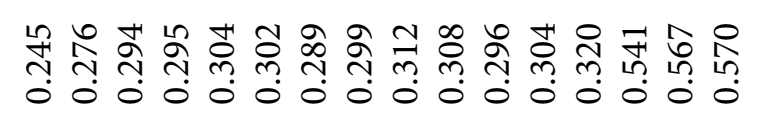 & 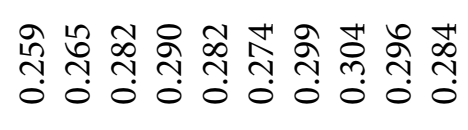 \\
\hline & $\alpha^{\circ} .0 .0$ & $\underset{1}{0} \stackrel{m}{+}$ & 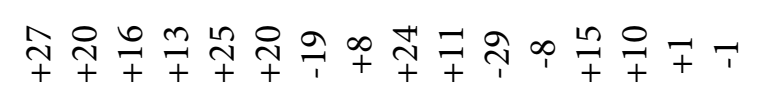 & 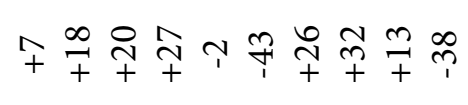 \\
\hline & $\stackrel{0}{ }$ & $\stackrel{\sim}{\sim} \stackrel{\infty}{\exists} \underset{m}{m}$ & 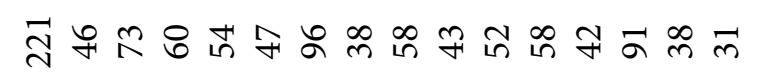 & 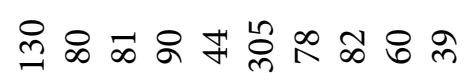 \\
\hline & 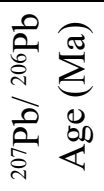 & 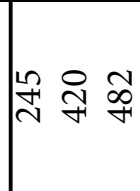 & 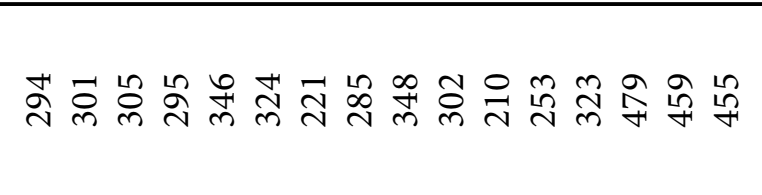 & 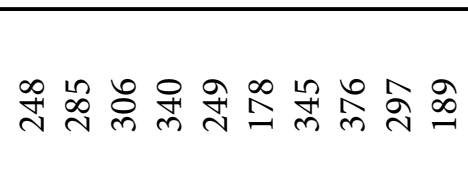 \\
\hline \multirow{6}{*}{ 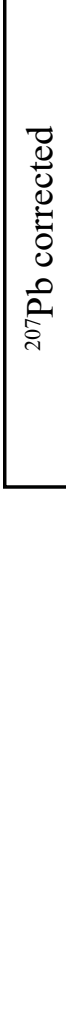 } & $\stackrel{0}{-}$ & $m \sim m$ & 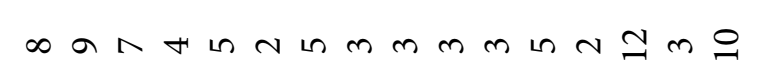 & 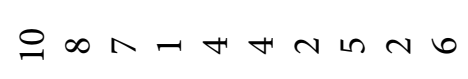 \\
\hline & 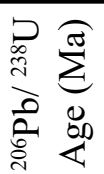 & 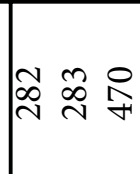 & 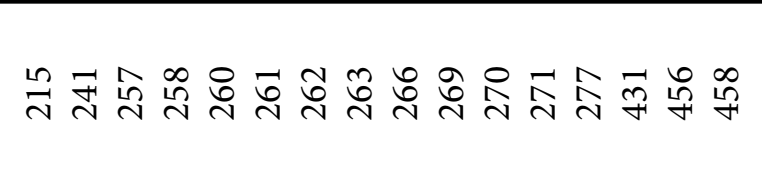 & 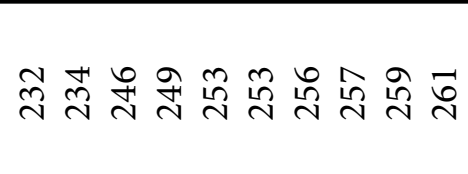 \\
\hline & 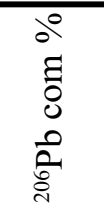 & $\mid$\begin{tabular}{lll}
$m$ & 0 & 0 \\
\hdashline & 0 & 0 \\
$i$ & 0 & 0
\end{tabular} & 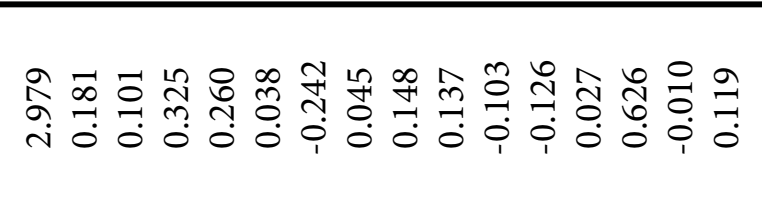 & 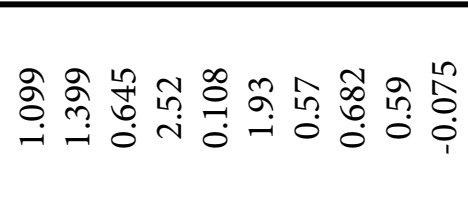 \\
\hline & Е 高 & 余号 & 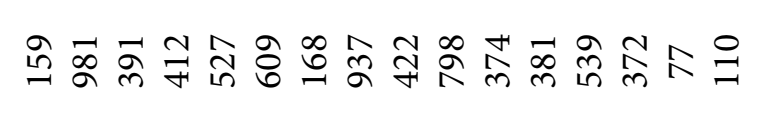 & 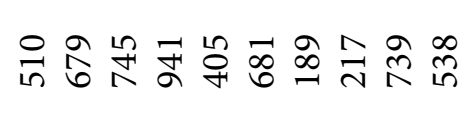 \\
\hline & $\supset$ 总 & 苾号 & 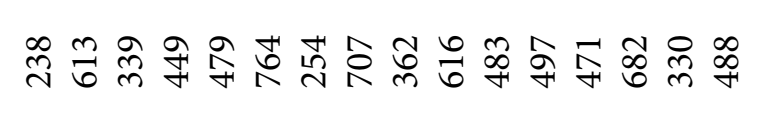 & 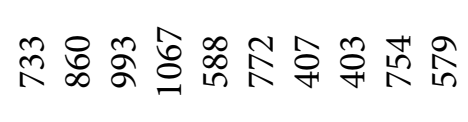 \\
\hline & 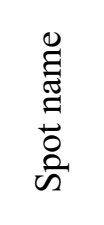 & 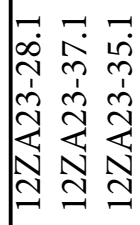 & 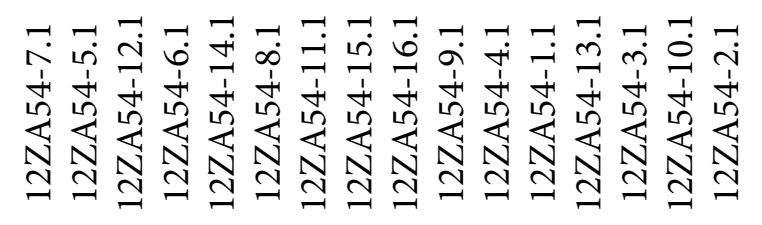 & 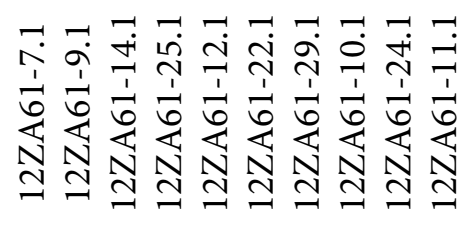 \\
\hline
\end{tabular}




\begin{tabular}{|c|c|c|c|}
\hline \multirow{8}{*}{ 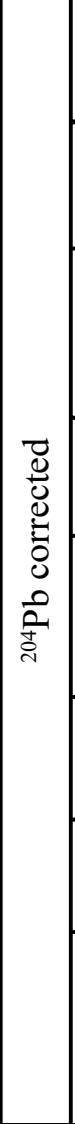 } & 苛突 & 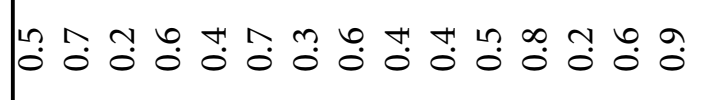 & 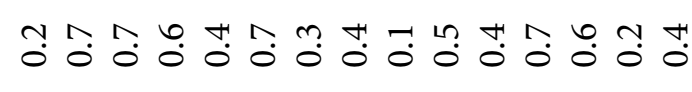 \\
\hline & 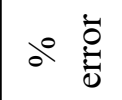 & 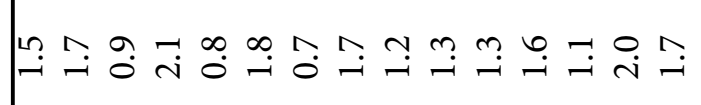 & 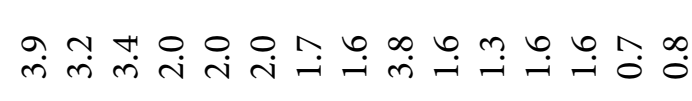 \\
\hline & 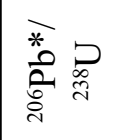 & 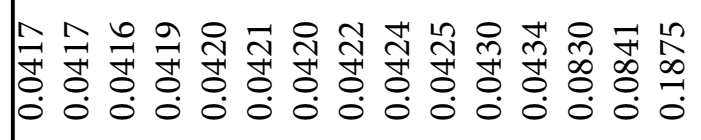 & 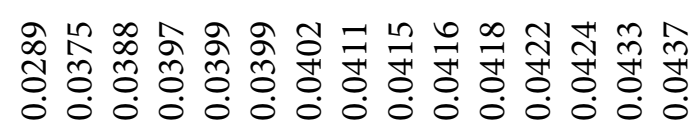 \\
\hline & ○ீ 苞 & 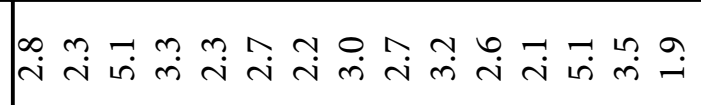 & 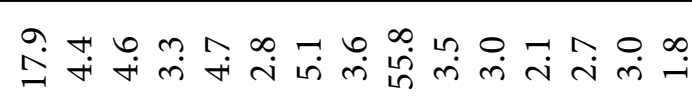 \\
\hline & 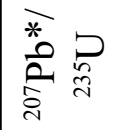 & 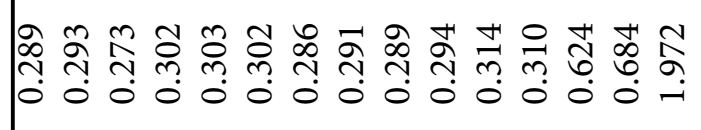 & 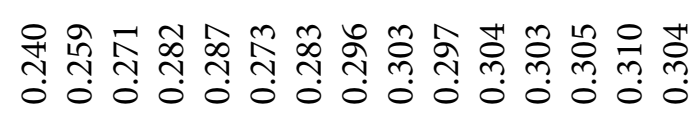 \\
\hline & $\partial^{\circ} . \frac{.0}{a}$ & 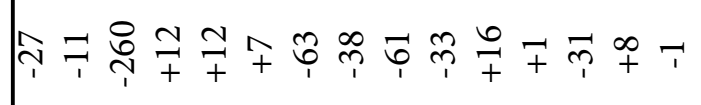 & 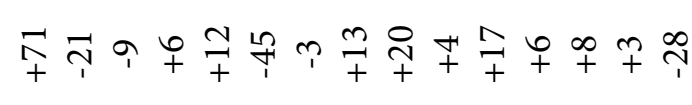 \\
\hline & $\underline{0}$ & 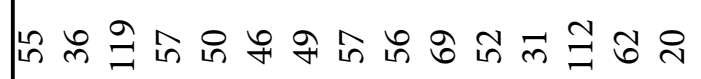 & 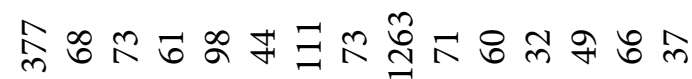 \\
\hline & 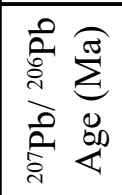 & 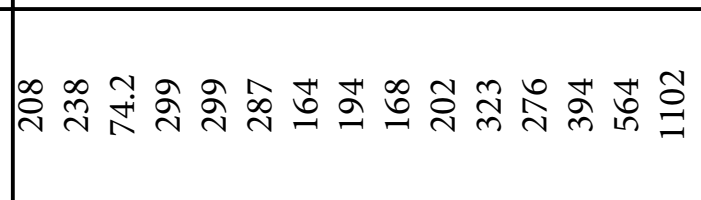 & 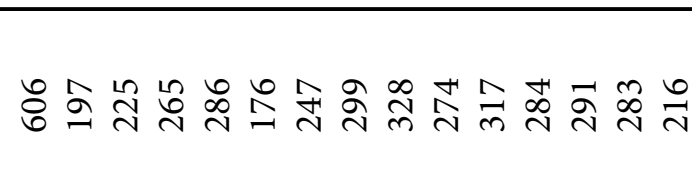 \\
\hline \multirow{3}{*}{ 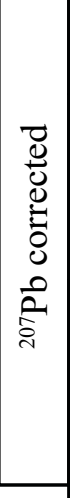 } & $\underline{0}$ & 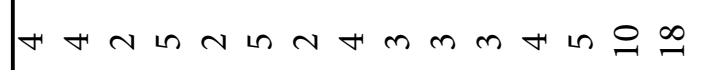 & $n \infty \infty \ln \ln \ln t h t a t a n d$ \\
\hline & 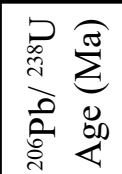 & 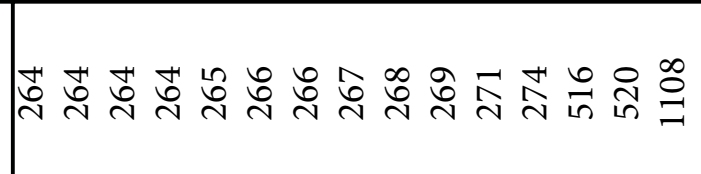 & వ \\
\hline & 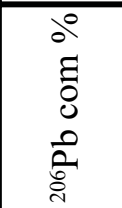 & 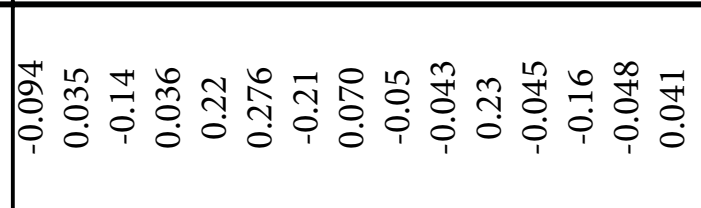 & 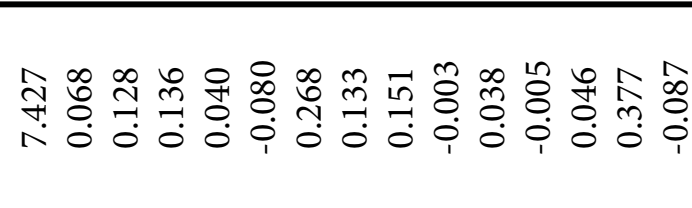 \\
\hline & Æ高 & 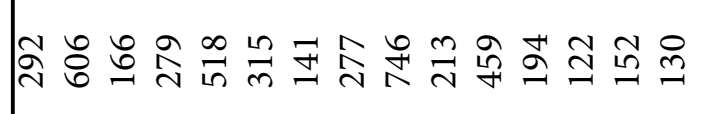 & fิ \\
\hline & $\triangleright$ है일 & 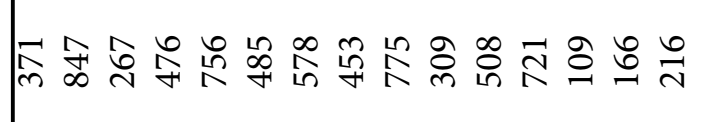 & : ন ₹ \\
\hline & 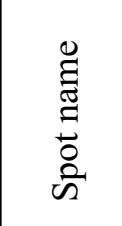 & 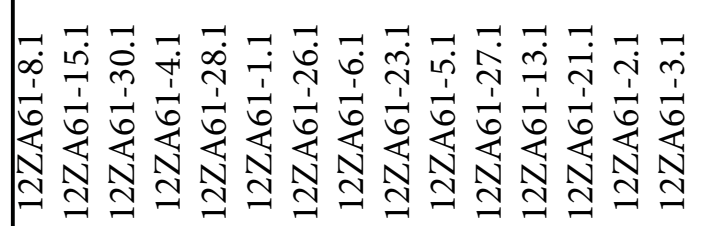 & 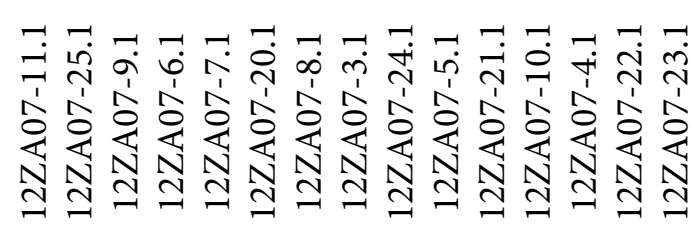 \\
\hline
\end{tabular}




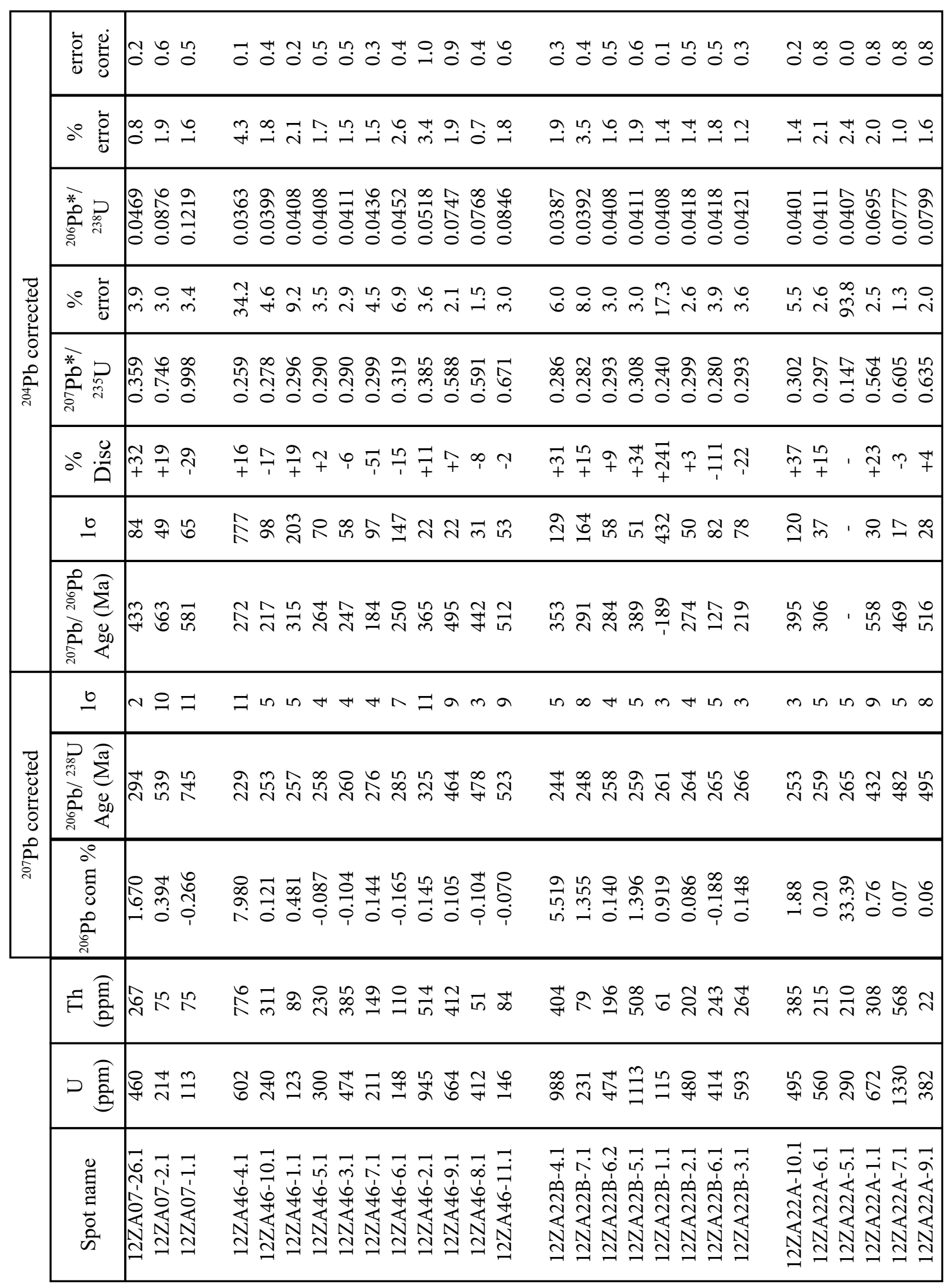




\begin{tabular}{|c|c|c|c|c|}
\hline \multirow{8}{*}{ 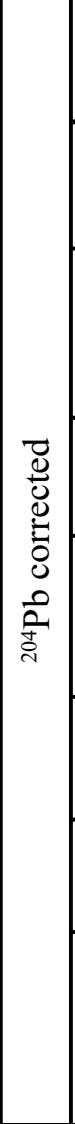 } & 离 & $\because n$ & 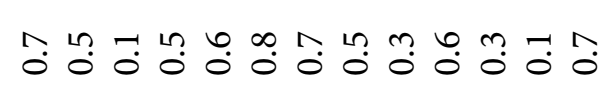 & 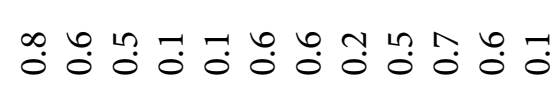 \\
\hline & वํั & 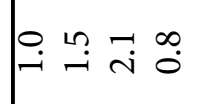 & 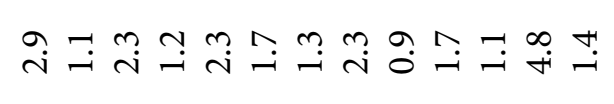 & 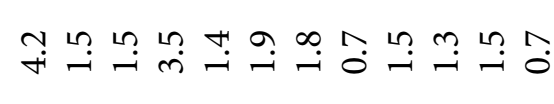 \\
\hline & 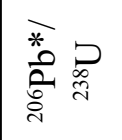 & 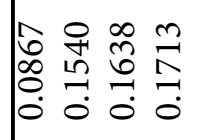 & 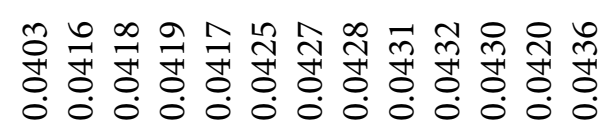 & 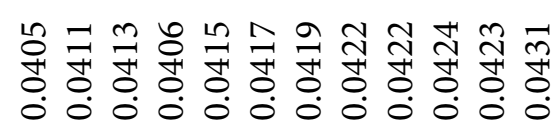 \\
\hline & 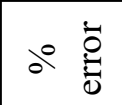 & $\stackrel{m}{i} \stackrel{m}{\rightarrow} \stackrel{m}{i}$ & 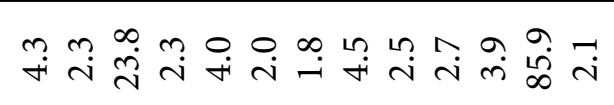 & 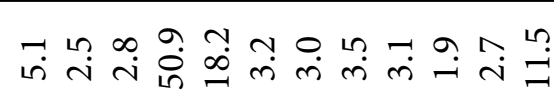 \\
\hline & 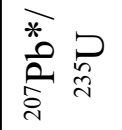 & 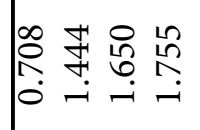 & 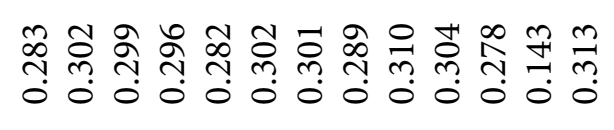 & 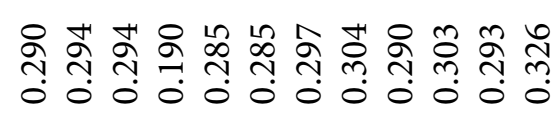 \\
\hline & $\partial^{\circ} . \frac{.0}{a}$ & 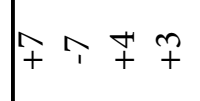 & 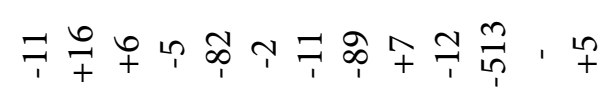 & 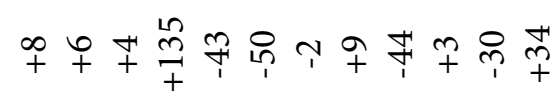 \\
\hline & $\underline{0}$ & হిळ๐ & 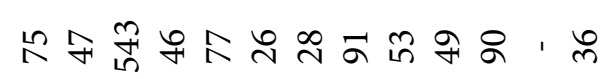 & 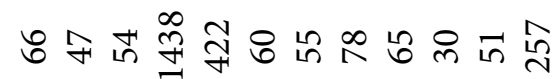 \\
\hline & 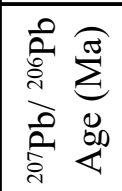 & 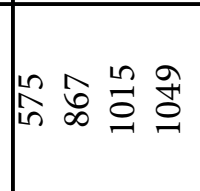 & 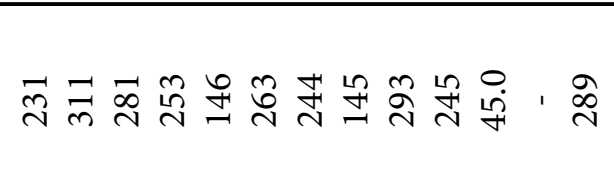 & 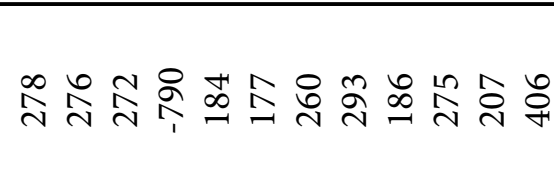 \\
\hline \multirow{6}{*}{ 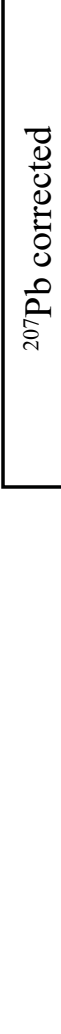 } & 음 & $\ln \approx \infty$ & 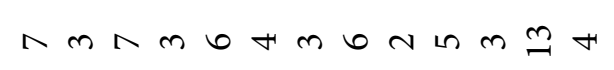 & $\exists+\pi$ 里 \\
\hline & 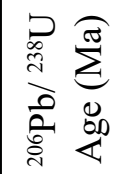 & 象 & 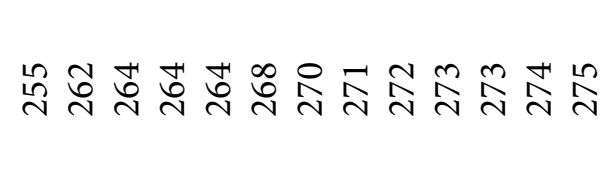 & 品 \\
\hline & 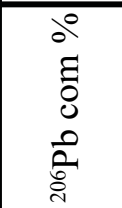 & $\mid \begin{array}{lll}0 & 0 & 0 \\
0 & 0 & 0 \\
-i & 0 & 0\end{array}$ & 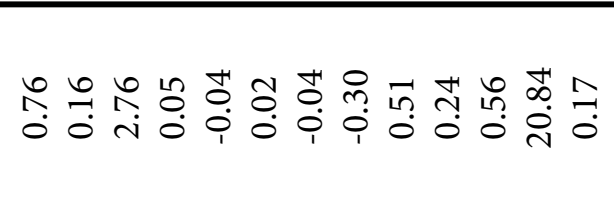 & 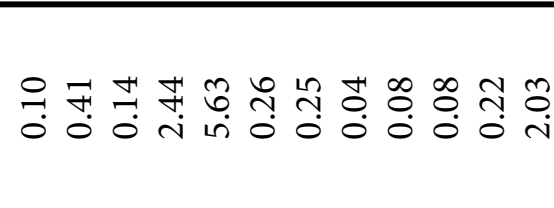 \\
\hline & Е 高 & $\stackrel{\infty}{0} \vec{\sim} \stackrel{\infty}{\circ}$ & 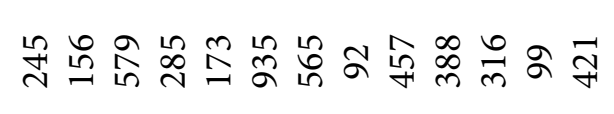 & 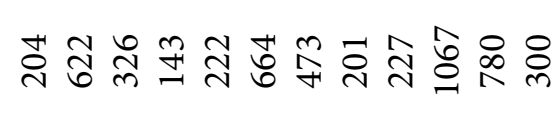 \\
\hline & $\triangleright$ है & क्षे & 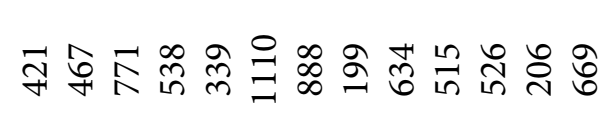 & 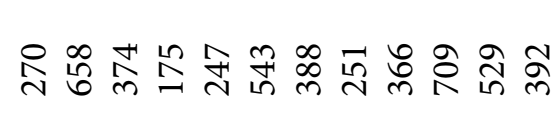 \\
\hline & $\begin{array}{l}\text { है } \\
\stackrel{\Xi}{\Xi} \\
\stackrel{0}{0} \\
\text { के }\end{array}$ & 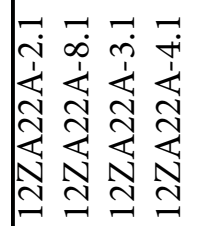 & 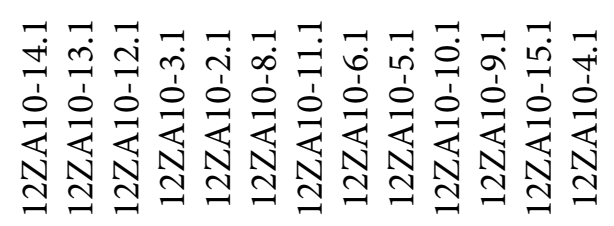 & 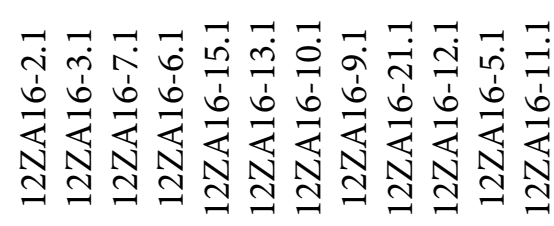 \\
\hline
\end{tabular}




\begin{tabular}{|c|c|c|c|c|}
\hline & 苛 & 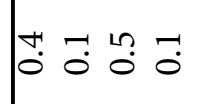 & 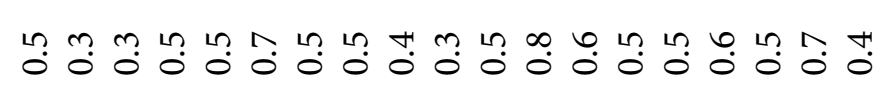 & 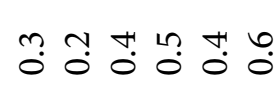 \\
\hline & ○ & $\stackrel{\infty}{0} \stackrel{\infty}{i}=\dot{0}$ & 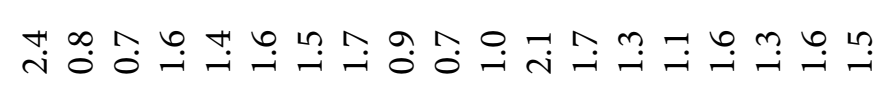 & 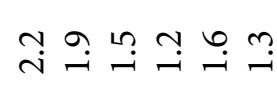 \\
\hline & 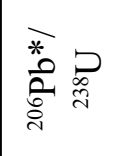 & 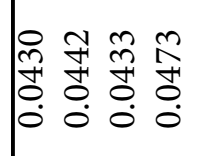 & 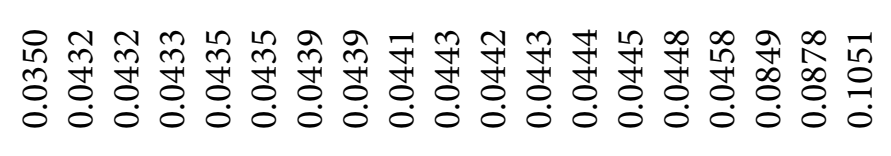 & 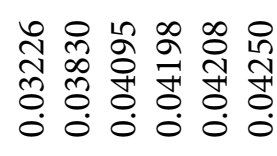 \\
\hline & ১० 苞 & 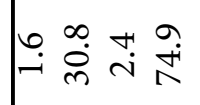 & 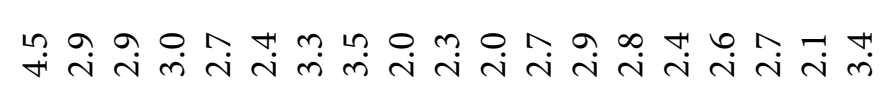 & 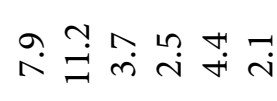 \\
\hline & 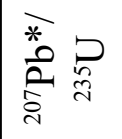 & 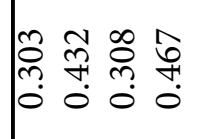 & 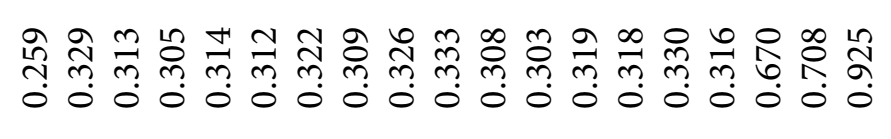 & 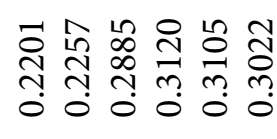 \\
\hline & 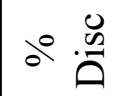 & $\int \frac{+}{\pi}$ & 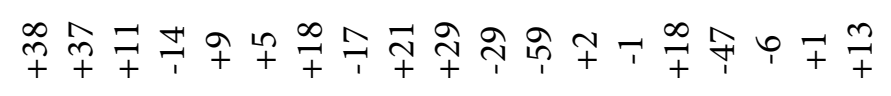 & 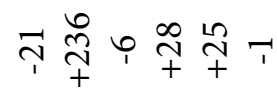 \\
\hline & $\underline{\bullet}$ & 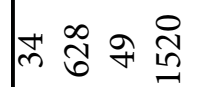 & 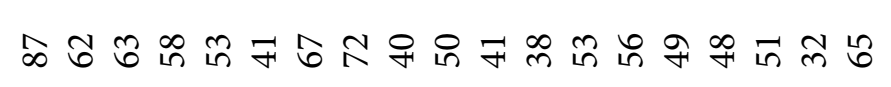 & 소송 \\
\hline & 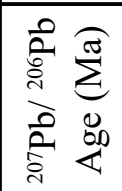 & ‡ & 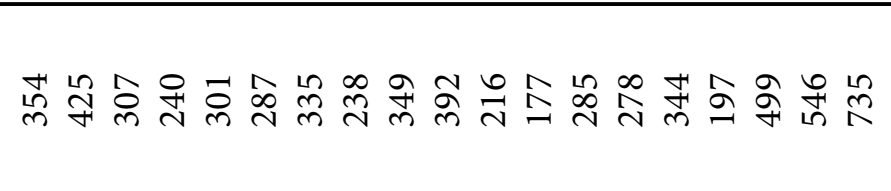 & 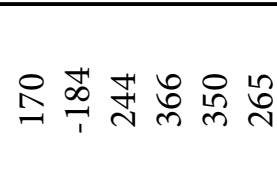 \\
\hline \multirow{3}{*}{ 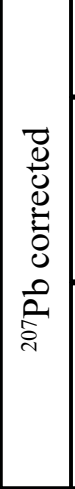 } & $\underline{0}$ & $N \circ n \stackrel{\sim}{\sim}$ & 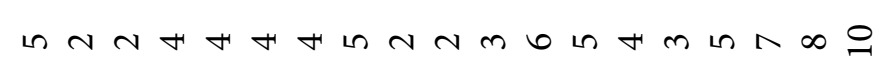 & $n+t m+n$ \\
\hline & 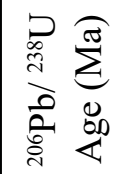 & 离 & 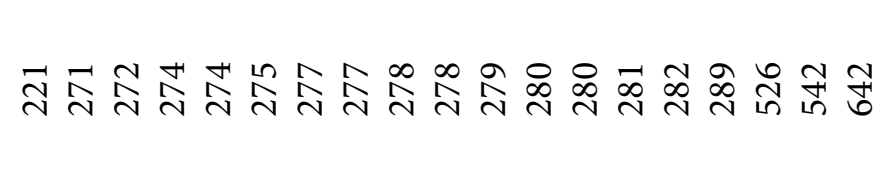 & 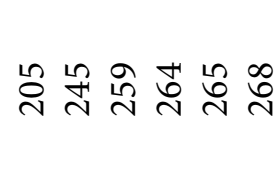 \\
\hline & 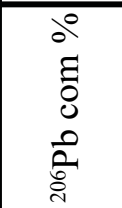 & 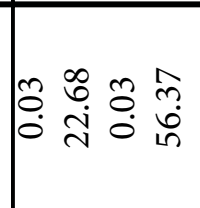 & 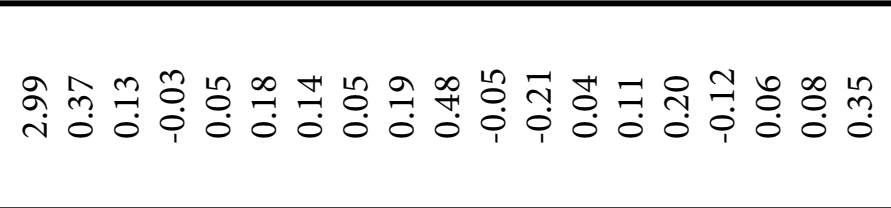 & 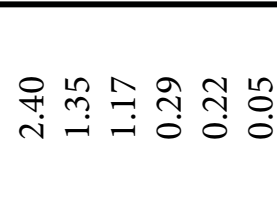 \\
\hline & Е 言 & 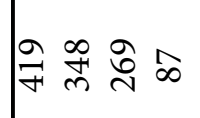 & 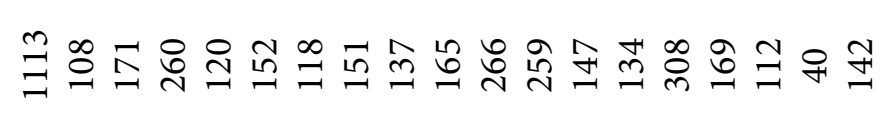 & 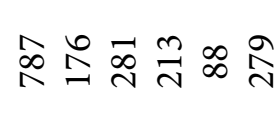 \\
\hline & $\supset$ 高 & 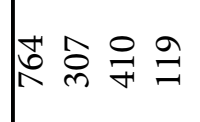 & 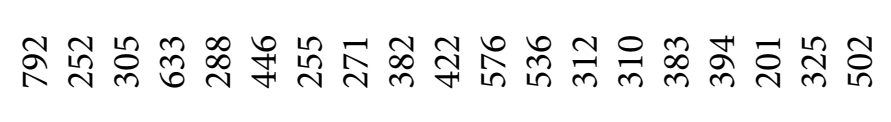 & 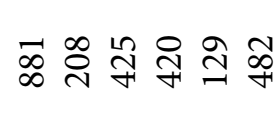 \\
\hline & 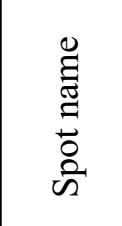 & 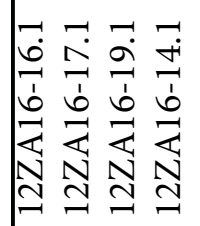 & 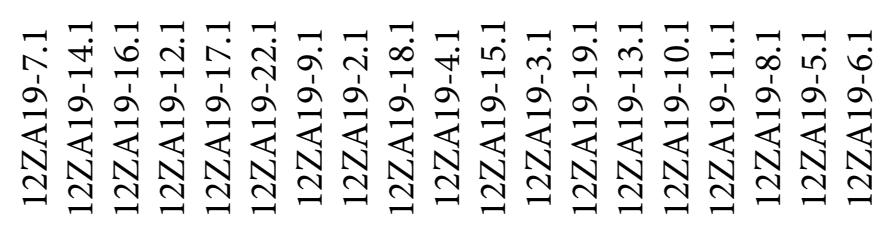 & 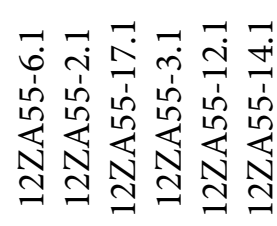 \\
\hline
\end{tabular}




\begin{tabular}{|c|c|c|c|c|}
\hline \multirow{8}{*}{ 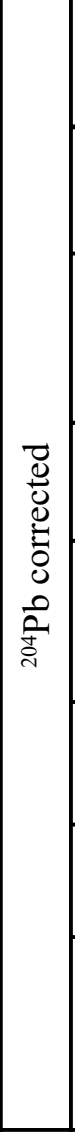 } & 窇 & 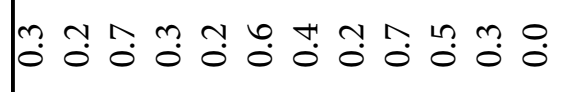 & 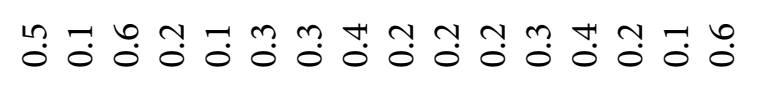 & ชี \\
\hline & ○ & 葛 & 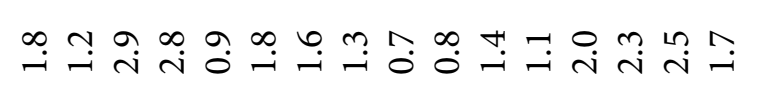 & $\stackrel{\circ}{+}$ \\
\hline & 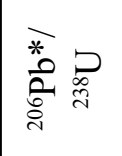 & 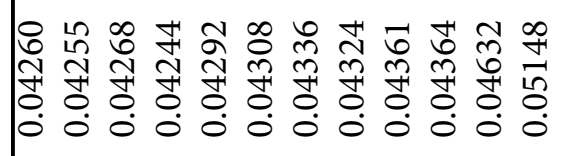 & 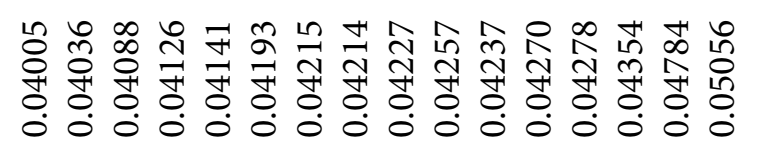 & 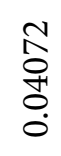 \\
\hline & 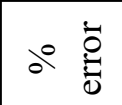 & 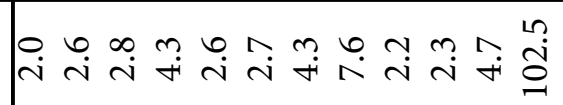 & 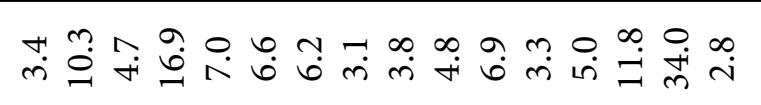 & $\stackrel{?}{=}$ \\
\hline & 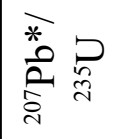 & 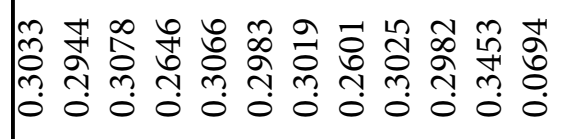 & 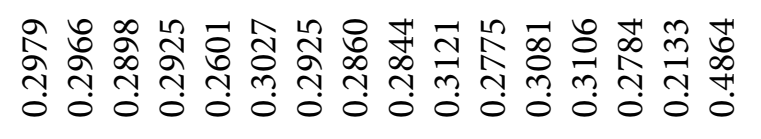 & $\begin{array}{l}\hat{\infty} \\
\infty \\
\stackrel{0}{0} \\
\stackrel{0}{0}\end{array}$ \\
\hline & $\partial^{\circ} .0 .0$ & i & 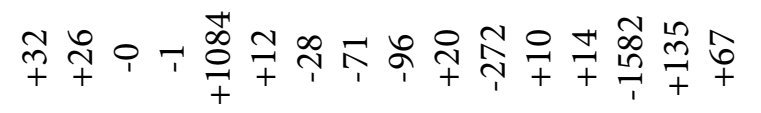 & ○ \\
\hline & 는 & 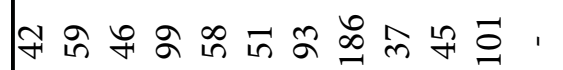 & 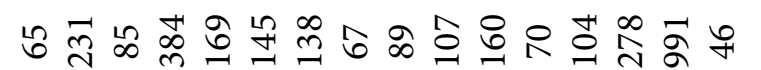 & 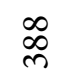 \\
\hline & 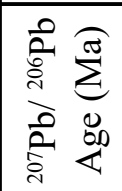 & 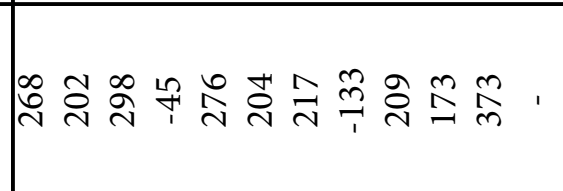 & 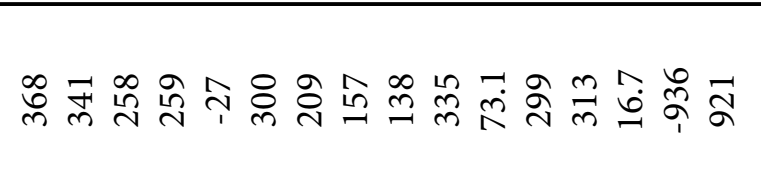 & ओे \\
\hline \multirow{3}{*}{ 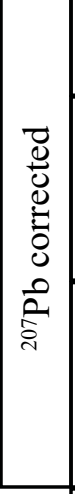 } & $\underline{0}$ & 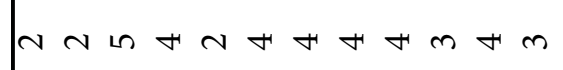 & 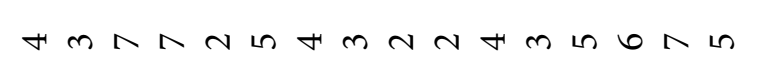 & 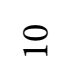 \\
\hline & 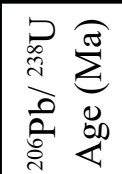 & 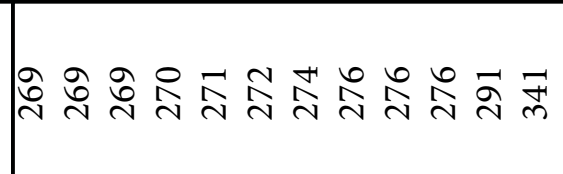 & 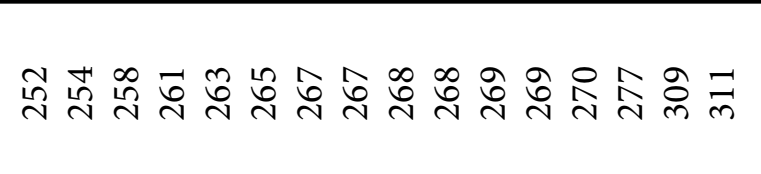 & 究 \\
\hline & 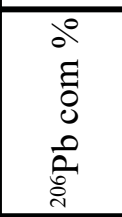 & 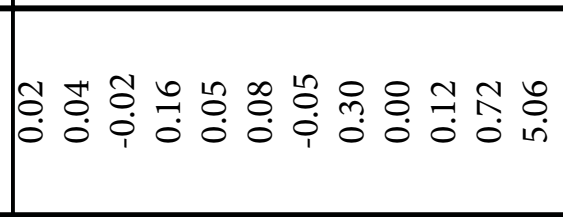 & 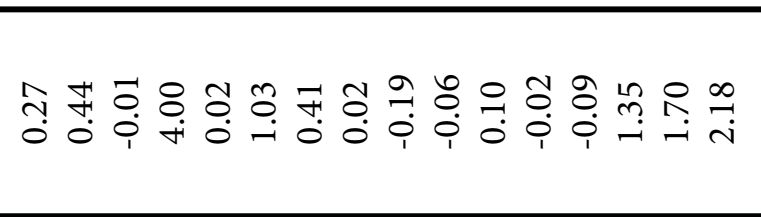 & $\stackrel{i}{:}$ \\
\hline & Е 高 & 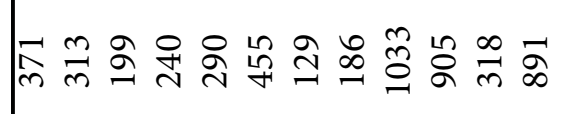 & 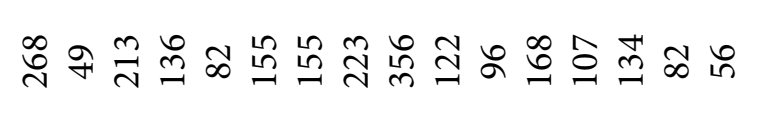 & $\stackrel{\infty}{\sim}$ \\
\hline & $\triangleright$ 高 & 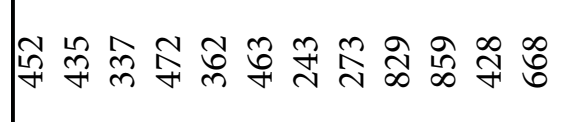 & 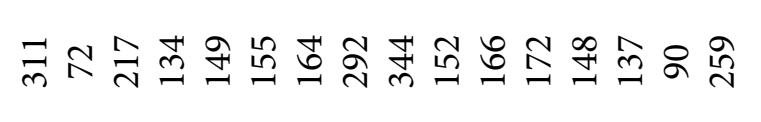 & $\stackrel{n}{\infty}$ \\
\hline & 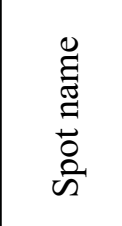 & 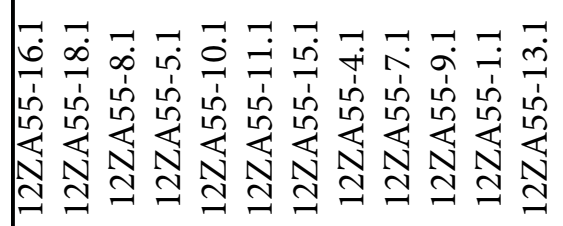 & 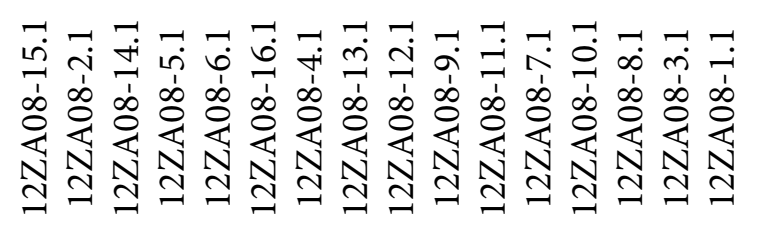 & 孛 \\
\hline
\end{tabular}




\begin{tabular}{|c|c|c|c|}
\hline \multirow{8}{*}{ 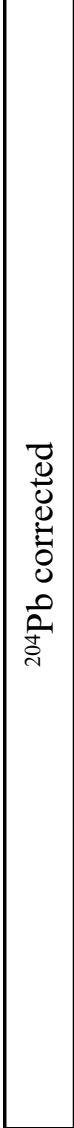 } & 突苟 & 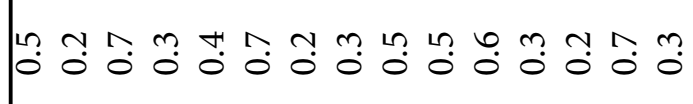 & 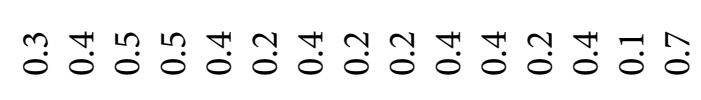 \\
\hline & $\therefore \stackrel{\breve{\Xi}}{0}$ & 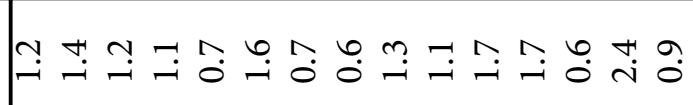 & 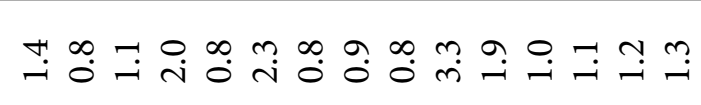 \\
\hline & 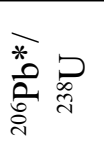 & 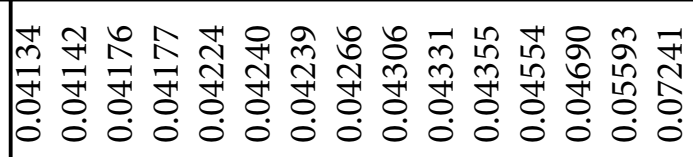 & 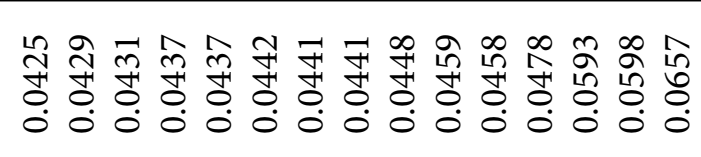 \\
\hline & 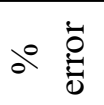 & 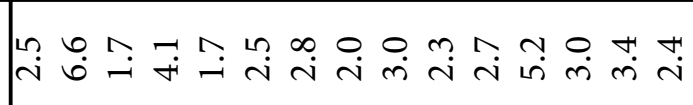 & 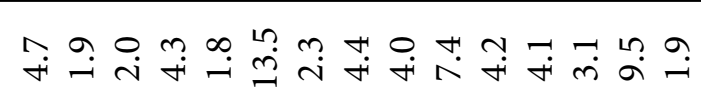 \\
\hline & 等 & 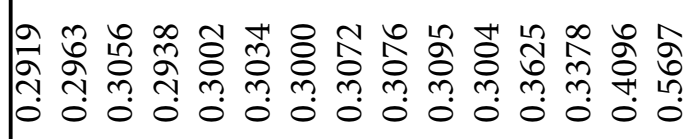 & 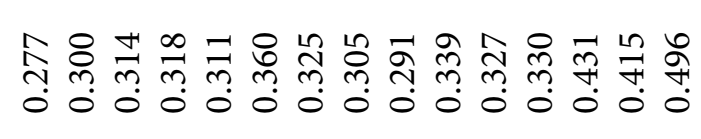 \\
\hline & $\alpha^{\circ} .0 .0$ & 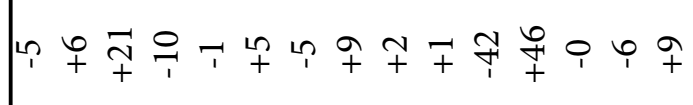 & 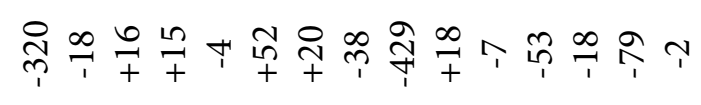 \\
\hline & $\stackrel{0}{-}$ & 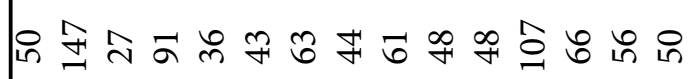 & \& \\
\hline & 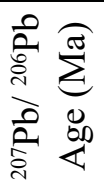 & 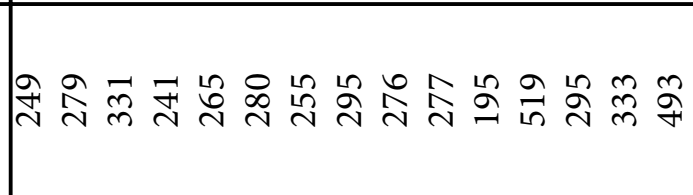 & 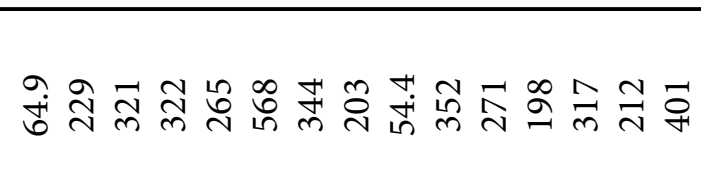 \\
\hline \multirow{6}{*}{ 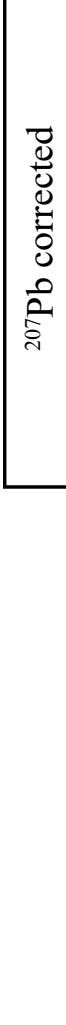 } & $\stackrel{0}{-}$ & 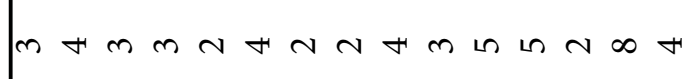 & HNm $n N N N N$ a \\
\hline & 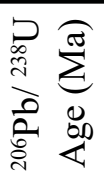 & 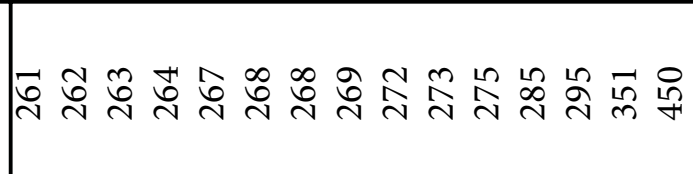 & 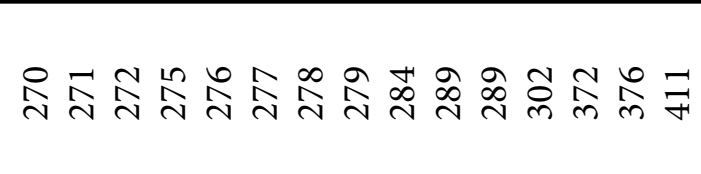 \\
\hline & 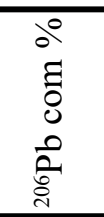 & 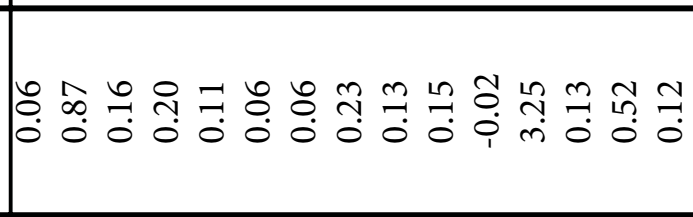 & 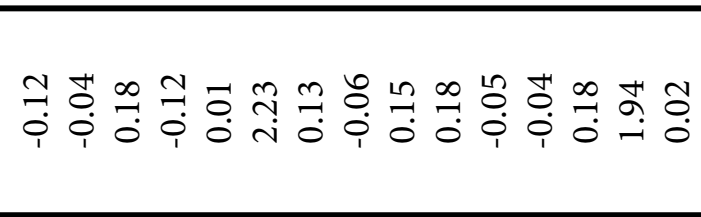 \\
\hline & $\approx \widehat{\hat{a}}$ & 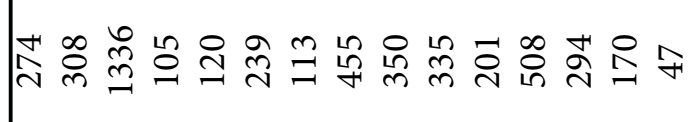 & 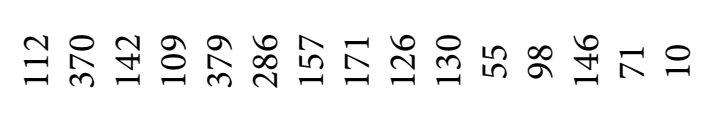 \\
\hline & $\supset$ 总 & 하융 & 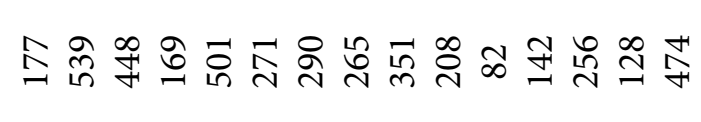 \\
\hline & 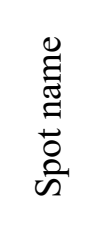 & 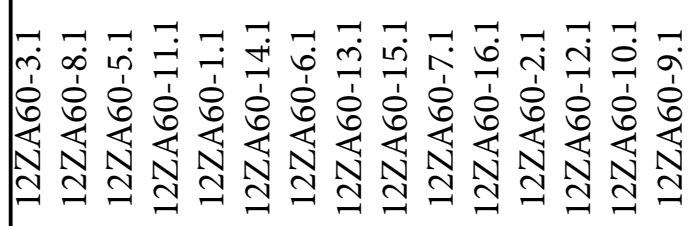 & 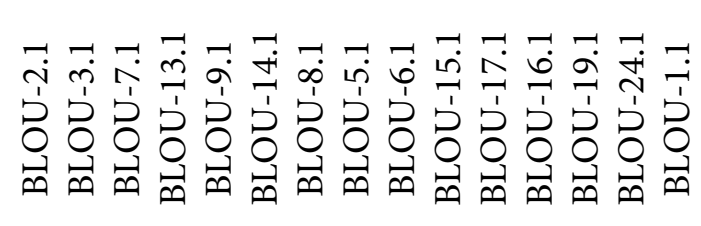 \\
\hline
\end{tabular}




\begin{tabular}{|c|c|c|c|c|}
\hline & 旁 & 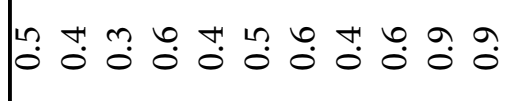 & 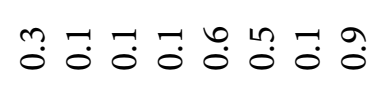 & 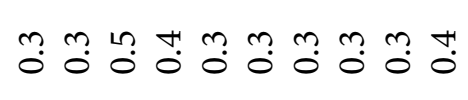 \\
\hline & 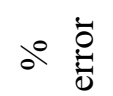 & 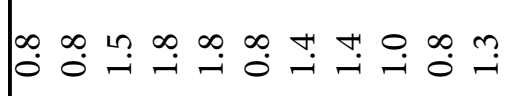 & 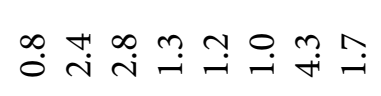 & 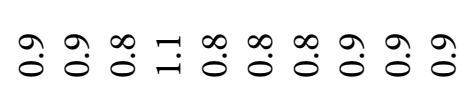 \\
\hline & 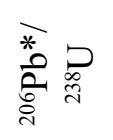 & 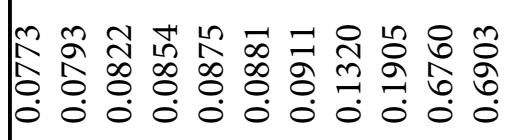 & 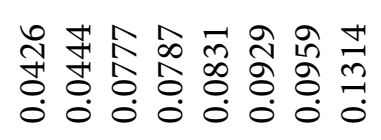 & 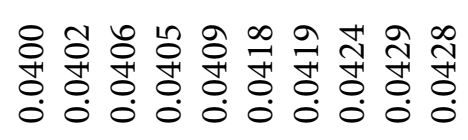 \\
\hline 苋 & वீ 苞 & 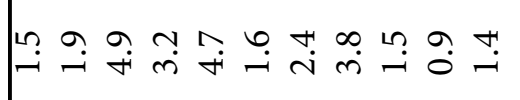 & 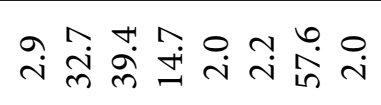 & 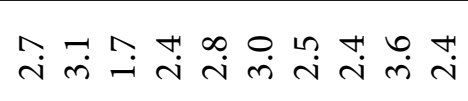 \\
\hline 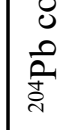 & 等 & 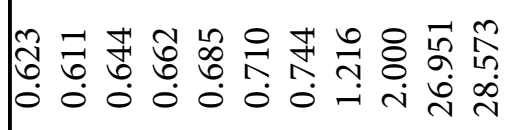 & 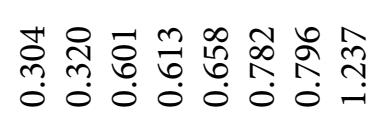 & 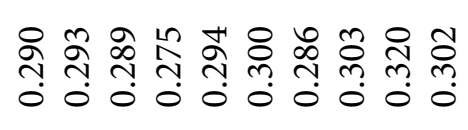 \\
\hline & م. & 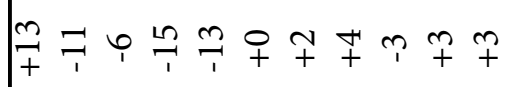 & m눟 & 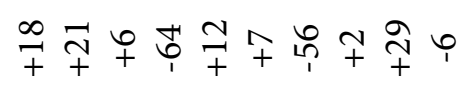 \\
\hline & $\underline{0}$ & 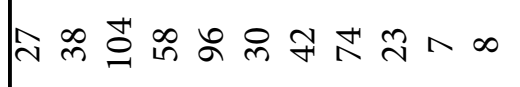 & 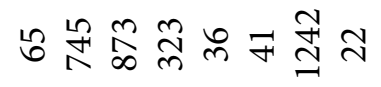 & 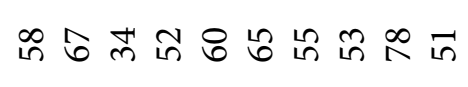 \\
\hline & 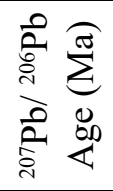 & 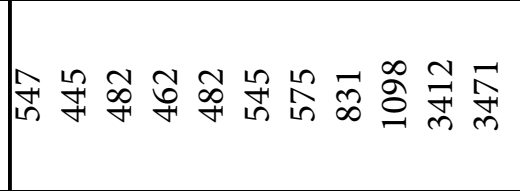 & 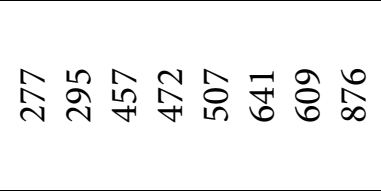 & 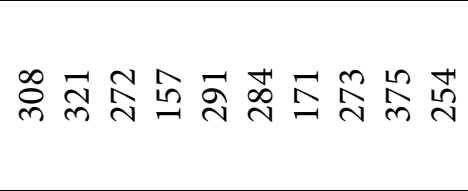 \\
\hline & $\stackrel{0}{-}$ & $H+\wedge ㅇ ㅡ,+\infty$ 음 & $N m+H 606 \Omega$ & $N \sim N m \sim N N N N N$ \\
\hline $\begin{array}{l}\overline{0} \\
\frac{0}{0} \\
\stackrel{0}{0}\end{array}$ & 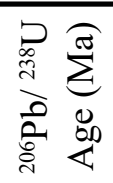 & 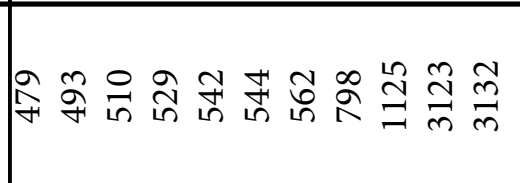 & 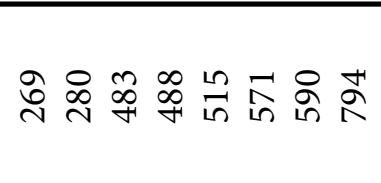 & 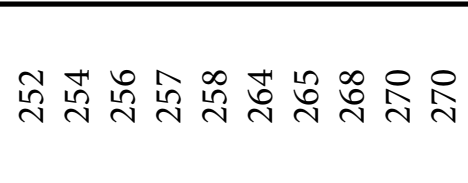 \\
\hline 点 & 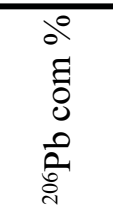 & 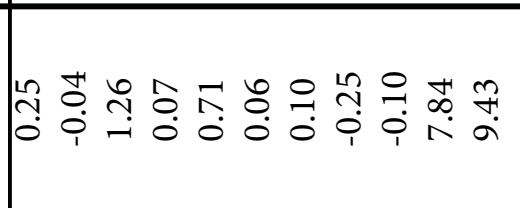 & 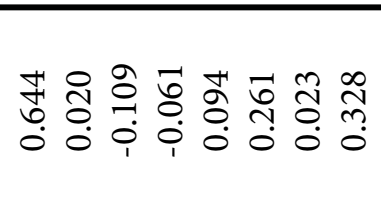 & 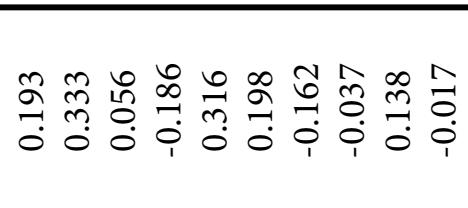 \\
\hline & $\approx \widehat{\hat{\partial}}$ & ๙ ঃ & 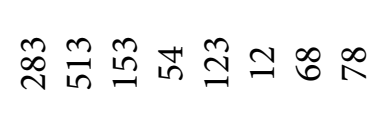 & 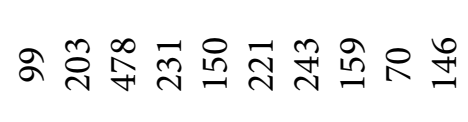 \\
\hline & $\supset \widehat{\hat{a}}$ & 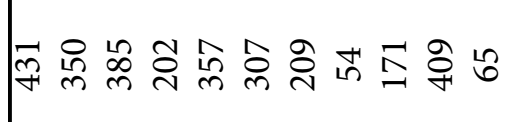 & 茋 & 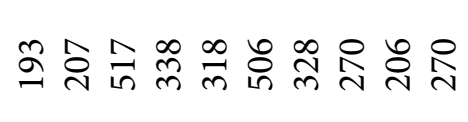 \\
\hline & 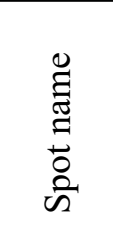 & 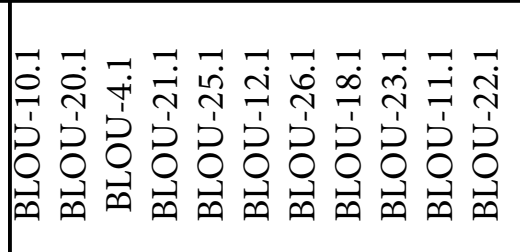 & 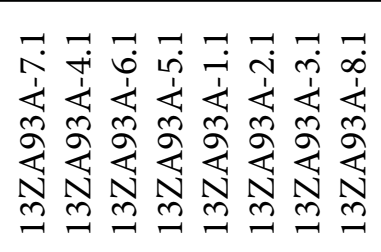 & 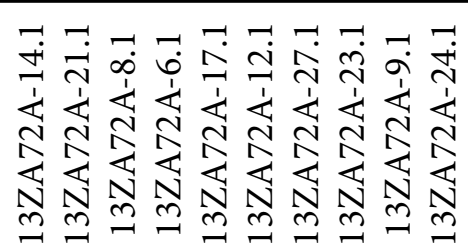 \\
\hline
\end{tabular}




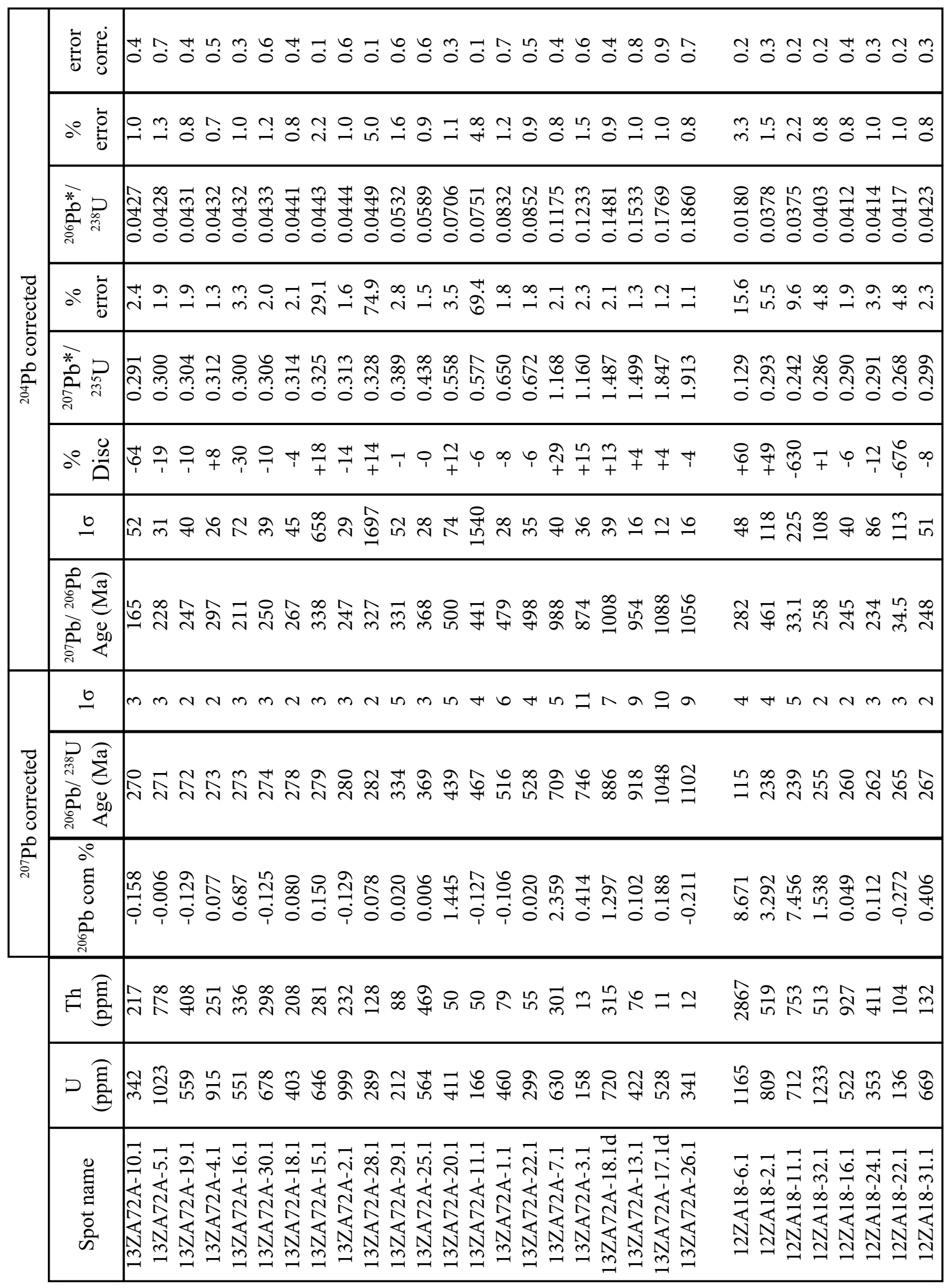




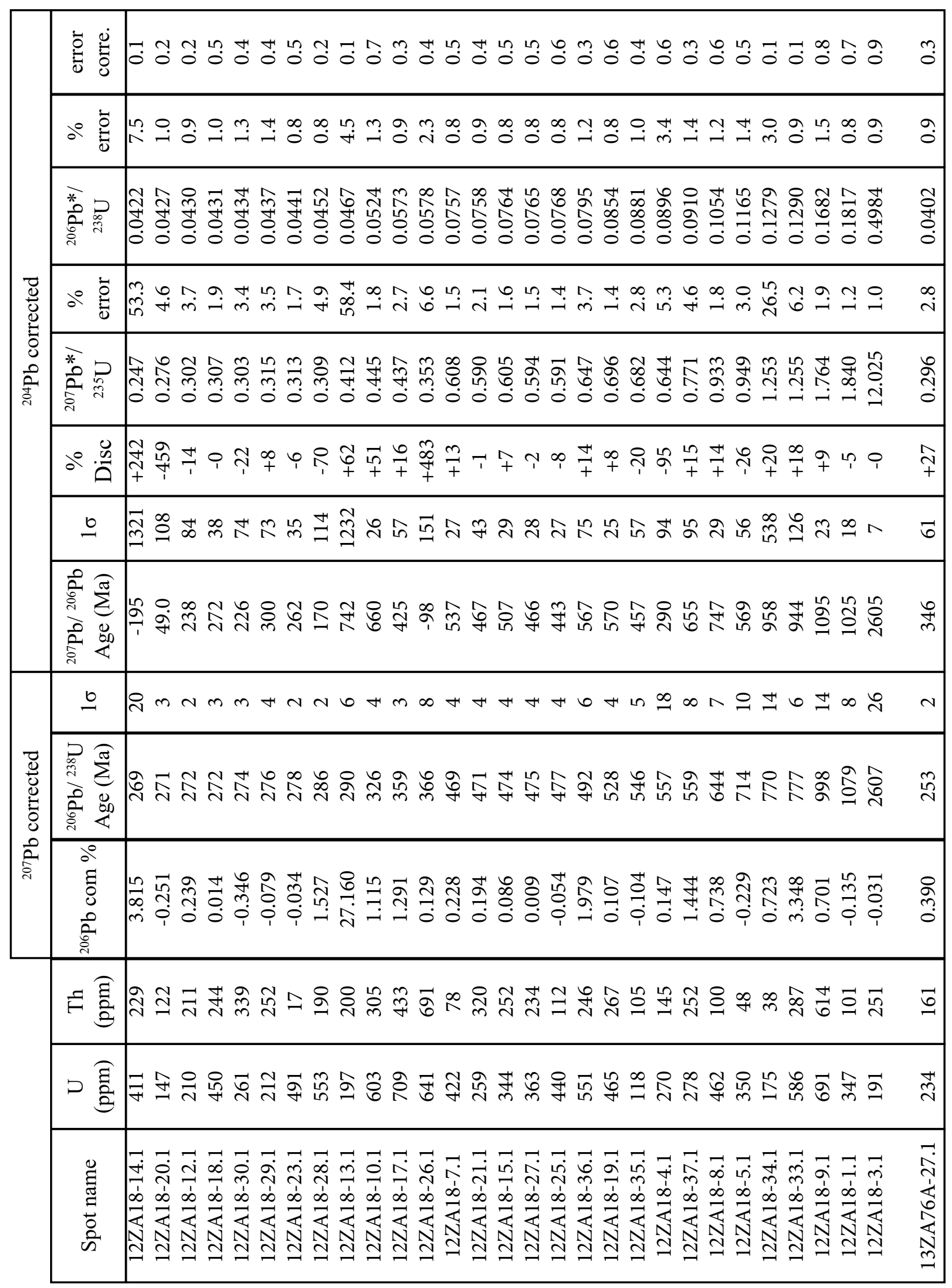




\begin{tabular}{|c|c|c|}
\hline \multirow{8}{*}{ 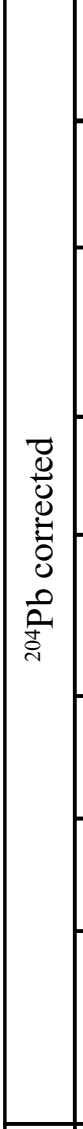 } & 吾 & 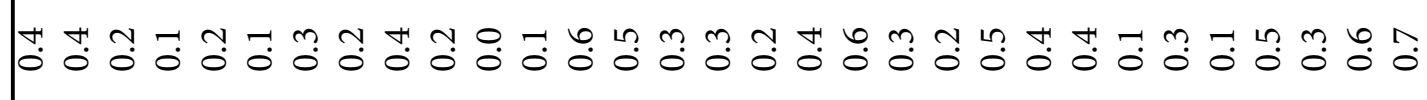 \\
\hline & $\therefore$ 节 & 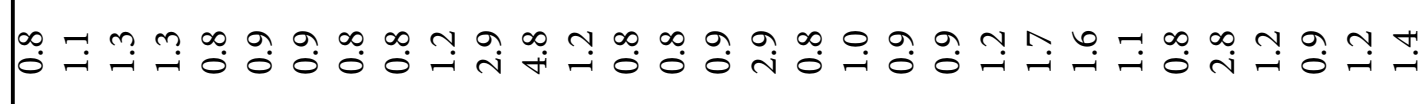 \\
\hline & 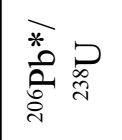 & 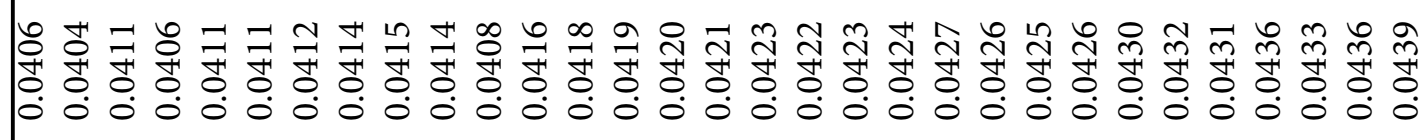 \\
\hline & ○ீ 苞 & 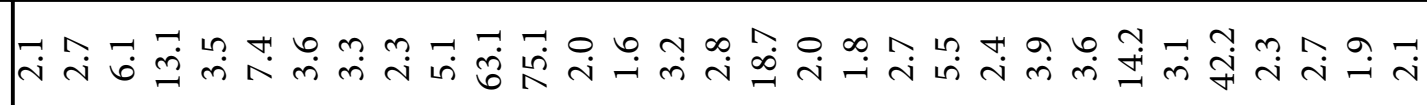 \\
\hline & 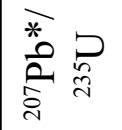 & 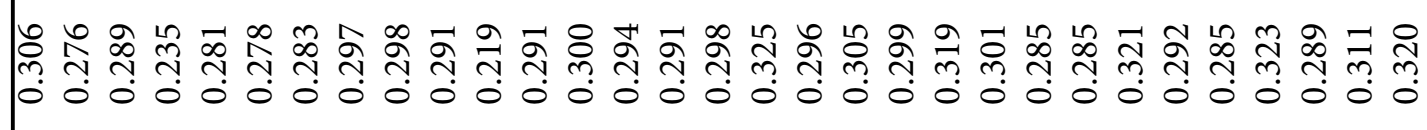 \\
\hline & 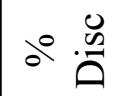 & 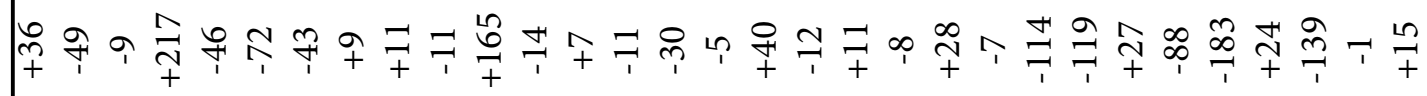 \\
\hline & $\underline{0}$ & 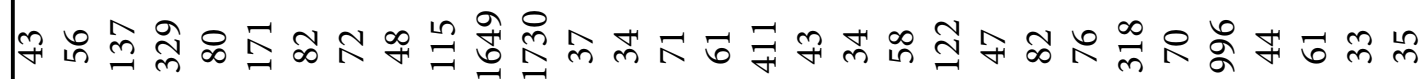 \\
\hline & 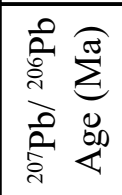 & 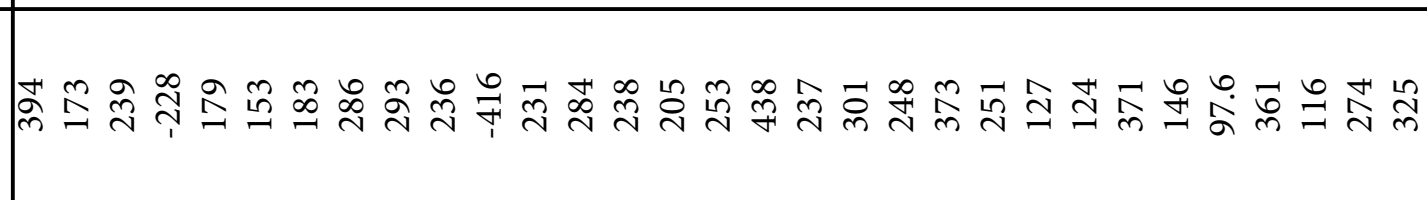 \\
\hline \multirow{3}{*}{ 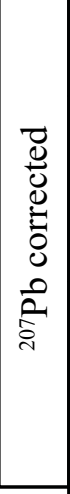 } & $\underline{0}$ & 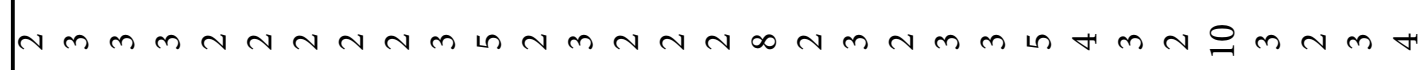 \\
\hline & 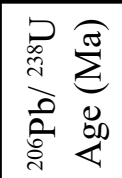 & 等 \\
\hline & 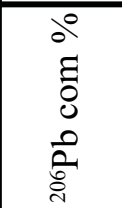 & 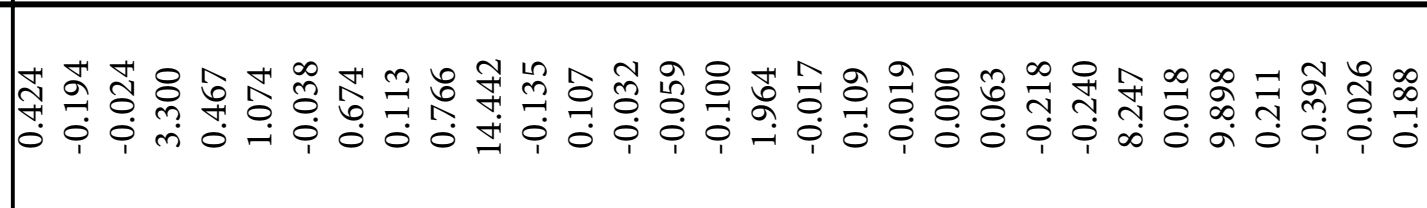 \\
\hline & $\Xi \widehat{\Xi}$ & 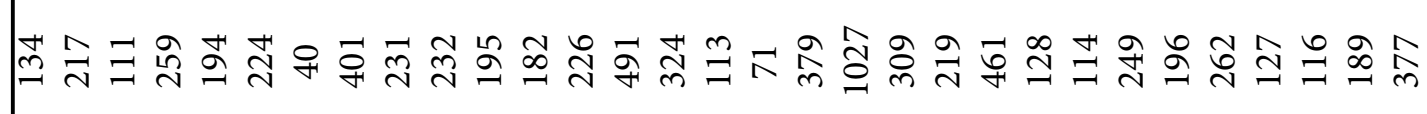 \\
\hline & $\supset \widehat{\hat{a}}$ & 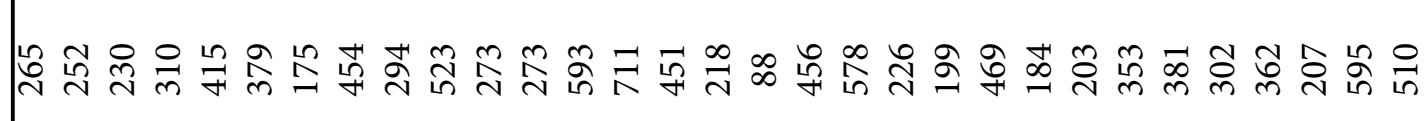 \\
\hline & 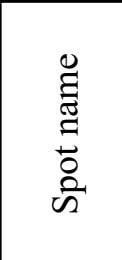 & 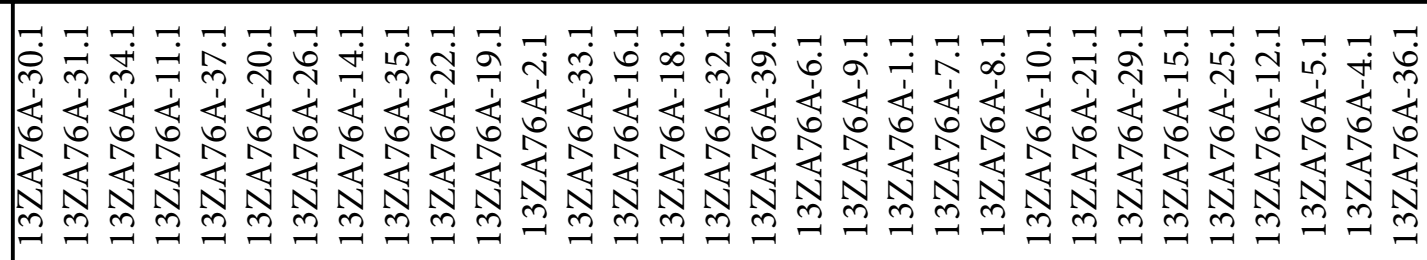 \\
\hline
\end{tabular}




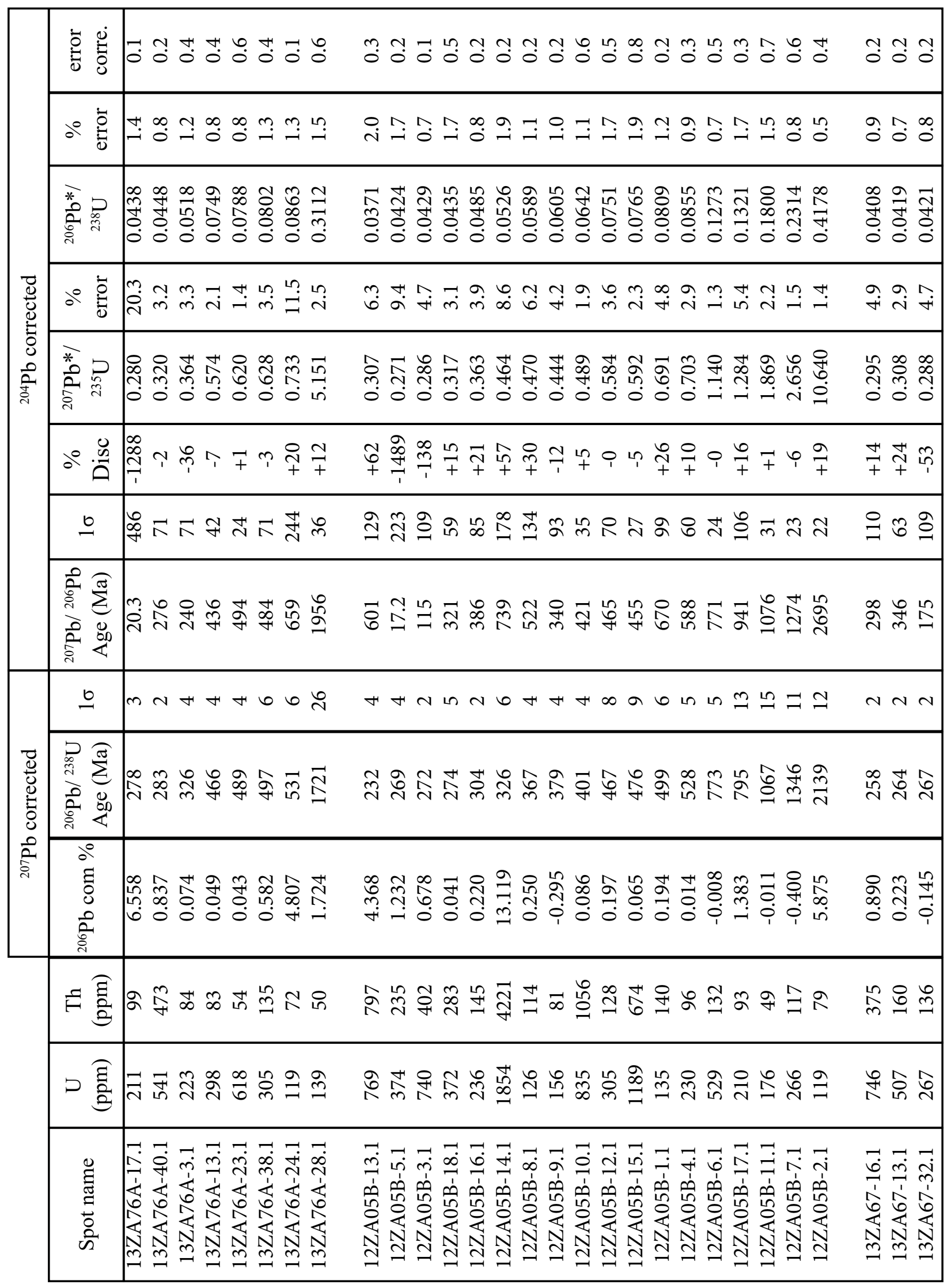




\begin{tabular}{|c|c|c|}
\hline \multirow{8}{*}{ 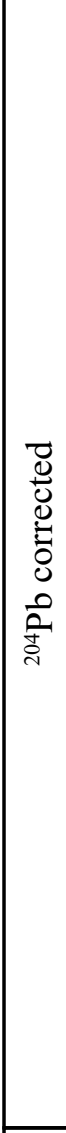 } & 药 & m. \\
\hline & 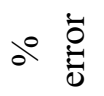 & 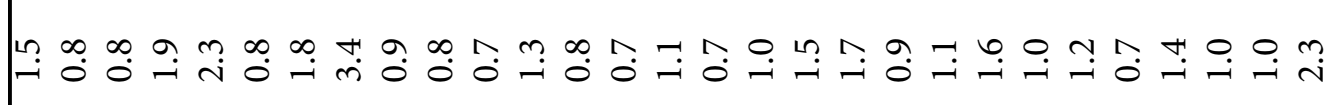 \\
\hline & 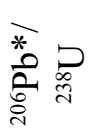 & 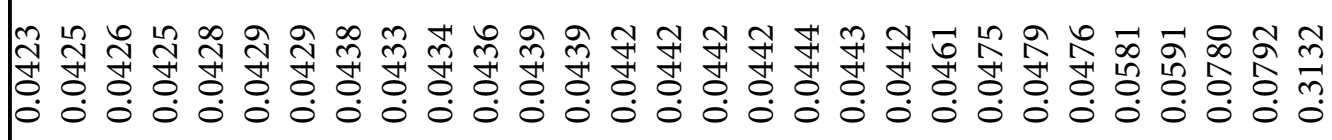 \\
\hline & $\therefore$ 苞 & 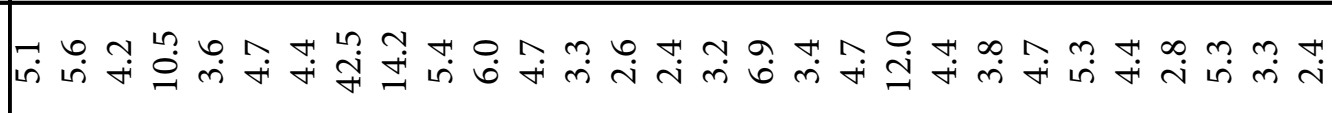 \\
\hline & 等 & 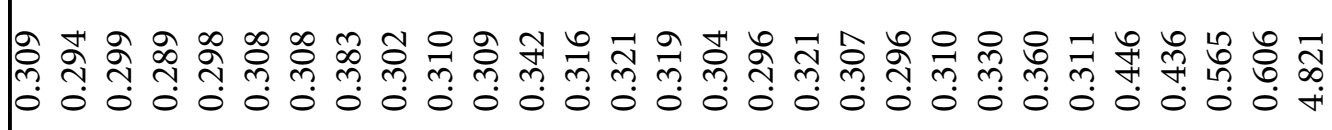 \\
\hline & $\therefore .0 .0$ & 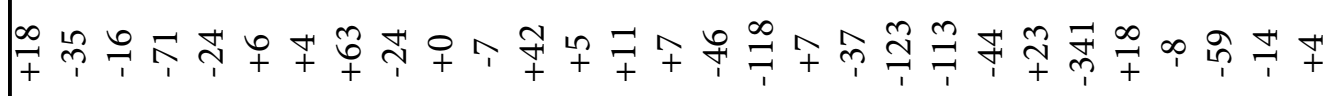 \\
\hline & $\underline{0}$ & O웍 \\
\hline & 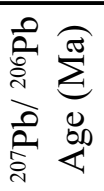 & 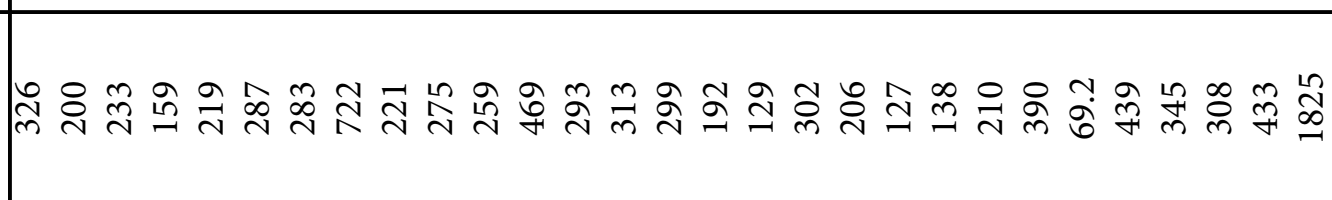 \\
\hline \multirow{3}{*}{ 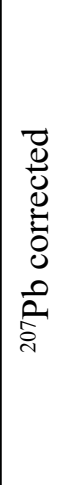 } & $\underline{0}$ & 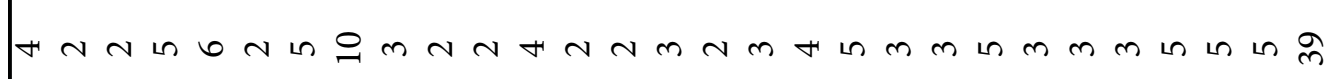 \\
\hline & 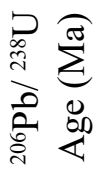 & i \\
\hline & $\begin{array}{l}\stackrel{0}{0}^{\circ} \\
\vdots \\
0 \\
0 \\
0 \\
0 \\
0 \\
0\end{array}$ & 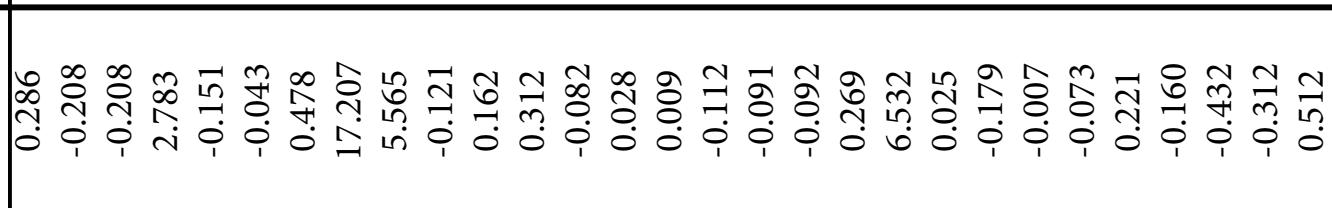 \\
\hline & $\approx \widehat{\hat{a}}$ & 요 \& \\
\hline & $\supset$ 言 & 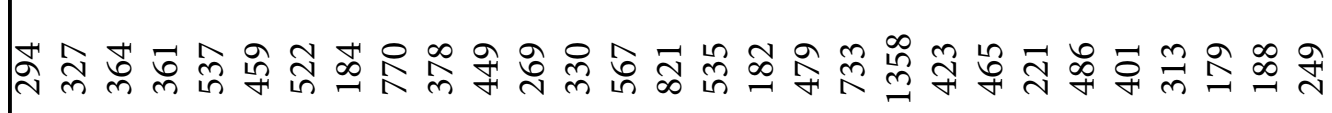 \\
\hline & 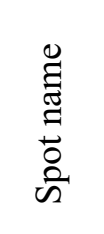 & 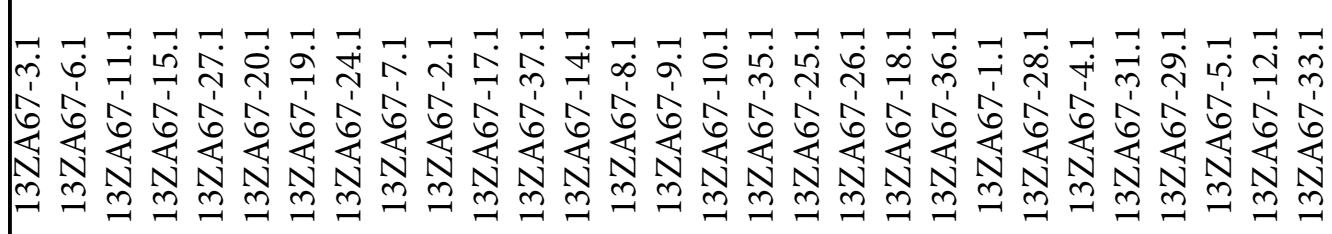 \\
\hline
\end{tabular}




\begin{tabular}{|c|c|c|}
\hline \multirow{8}{*}{ 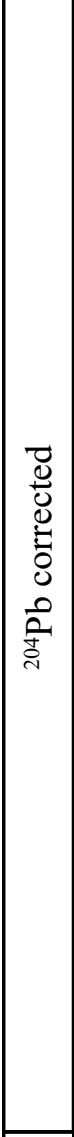 } & 至 & 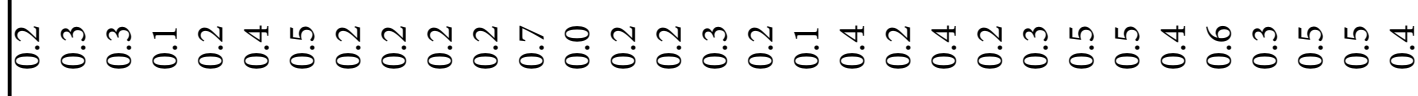 \\
\hline & $\therefore$ 苛 & 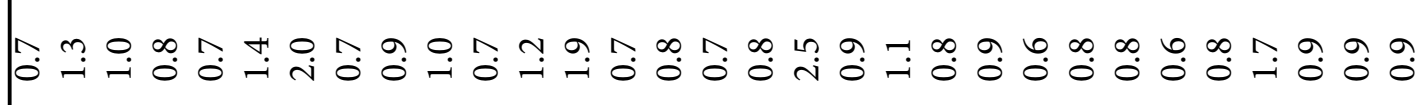 \\
\hline & 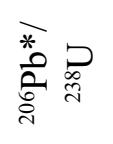 & 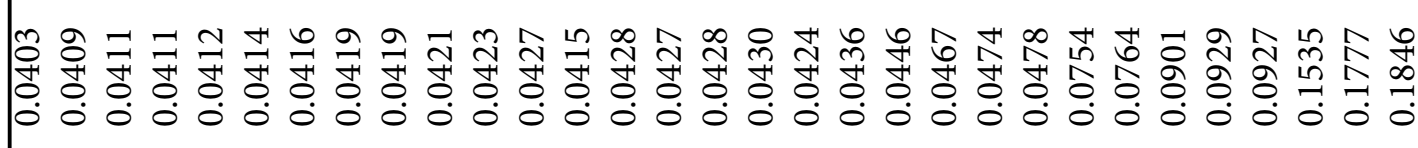 \\
\hline & 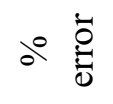 & 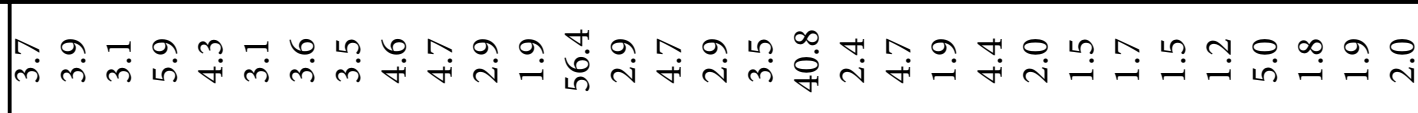 \\
\hline & 等 & 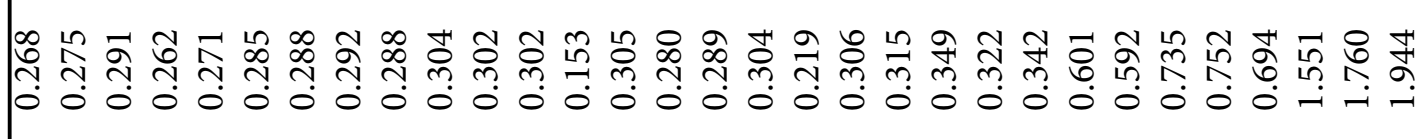 \\
\hline & $\therefore$ & 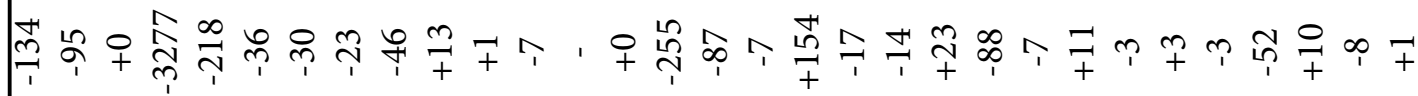 \\
\hline & $\stackrel{0}{\sim}$ & 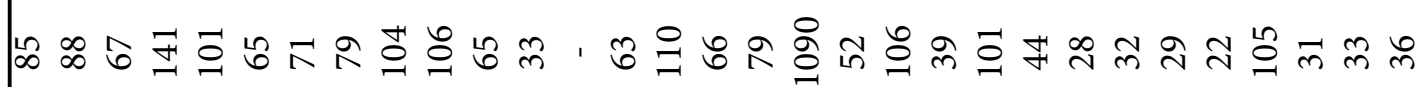 \\
\hline & 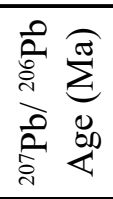 & 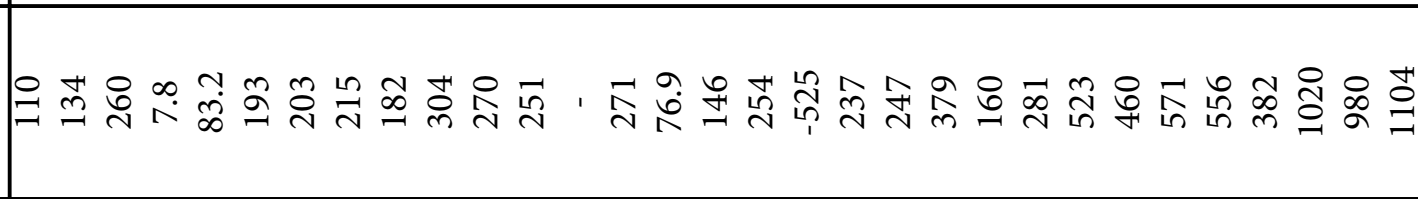 \\
\hline \multirow{3}{*}{ 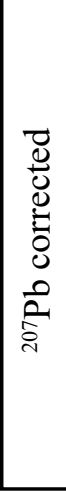 } & $\stackrel{0}{\sim}$ & 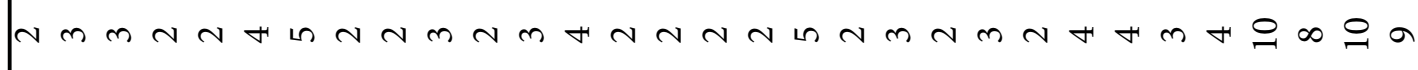 \\
\hline & 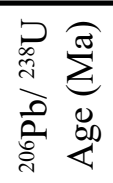 & 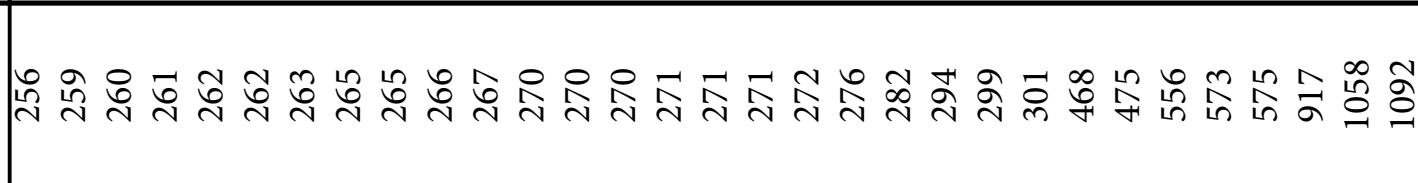 \\
\hline & 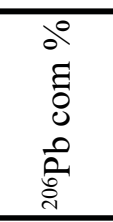 & 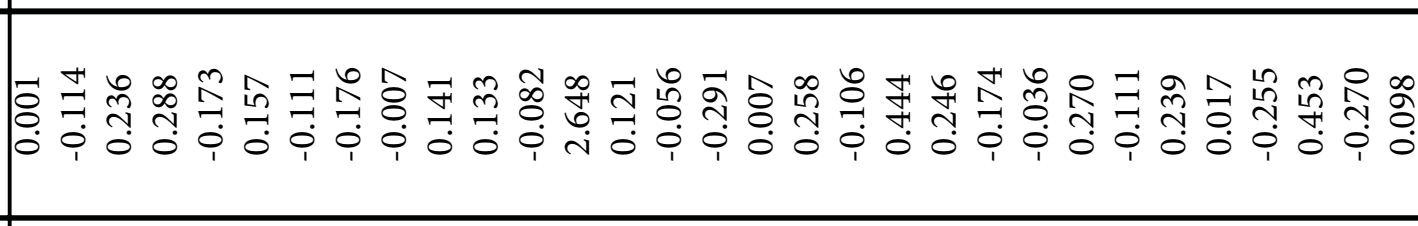 \\
\hline & $\approx \widehat{E}$ & 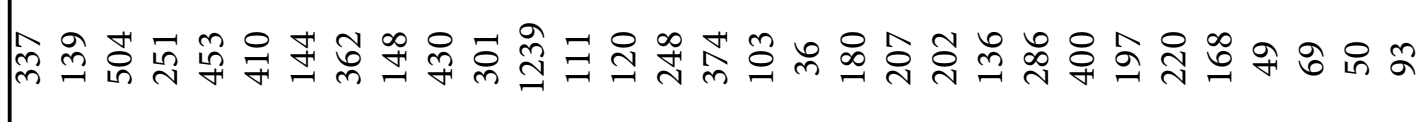 \\
\hline & $\triangleright$ है일 & 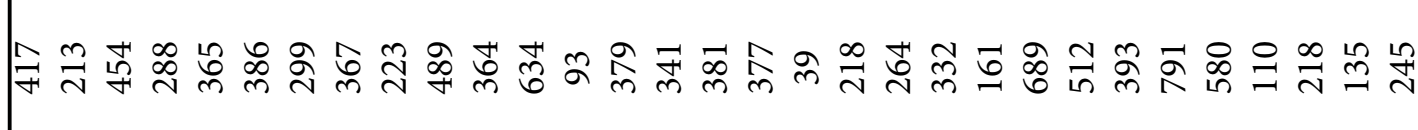 \\
\hline & 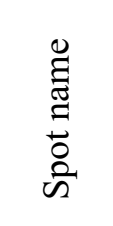 & 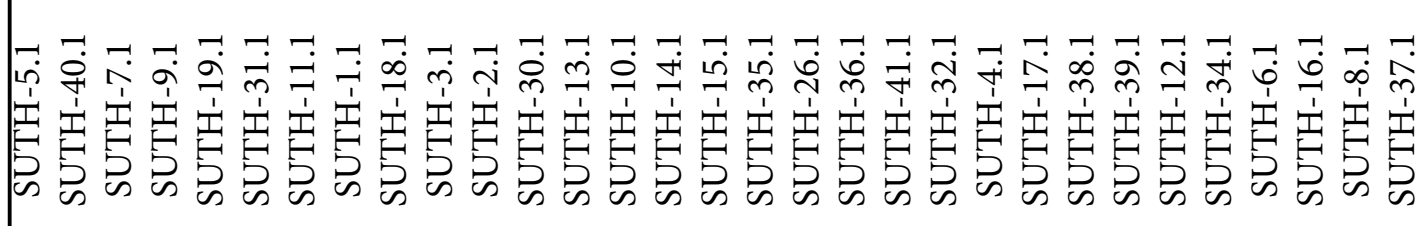 \\
\hline
\end{tabular}




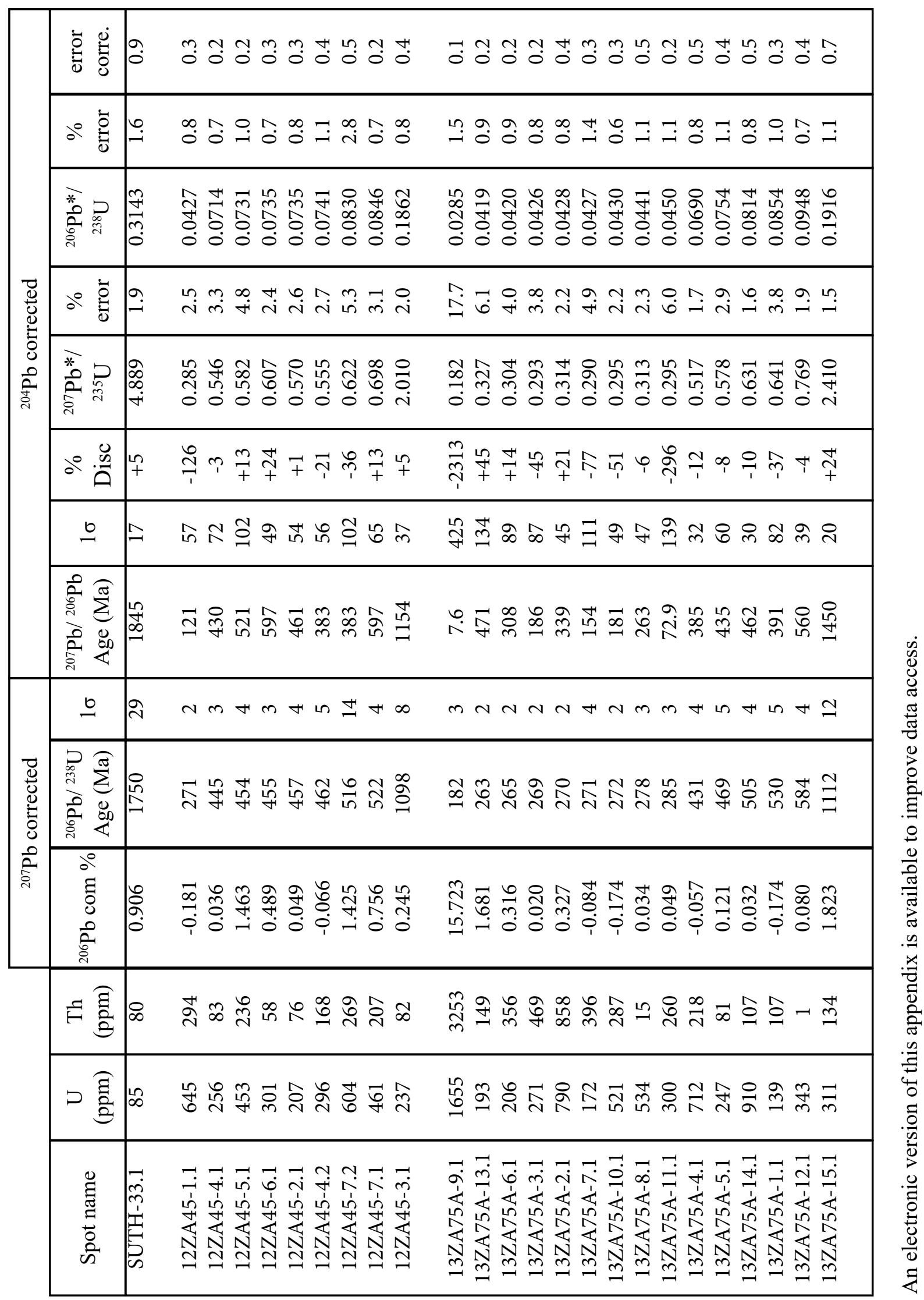




\begin{tabular}{|c|c|}
\hline & 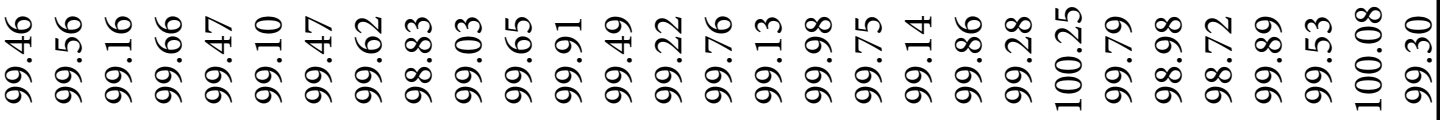 \\
\hline & 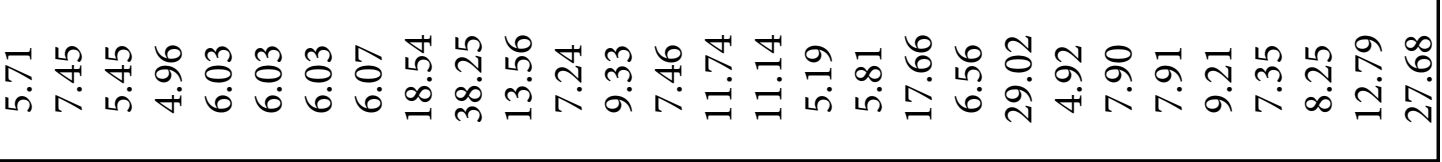 \\
\hline & 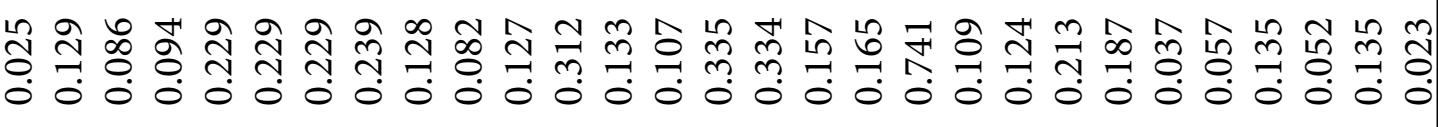 \\
\hline & 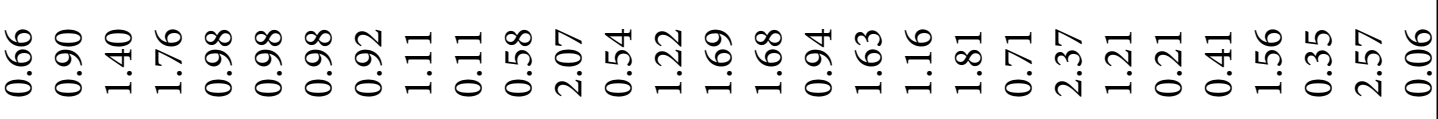 \\
\hline & 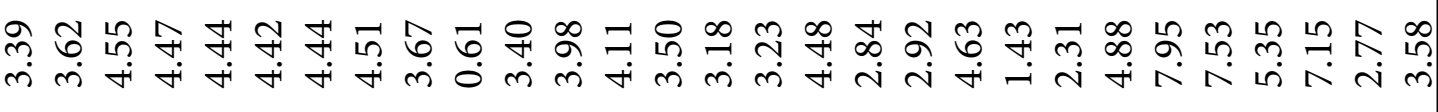 \\
\hline & 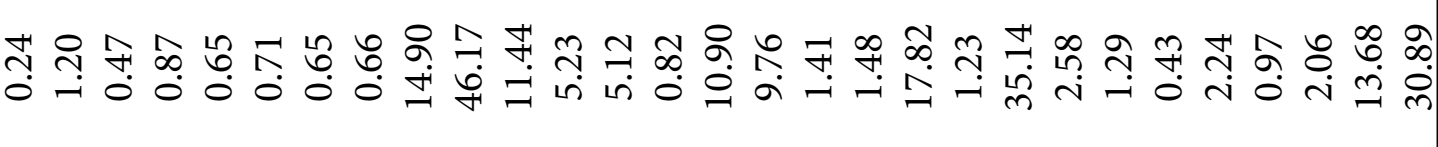 \\
\hline & 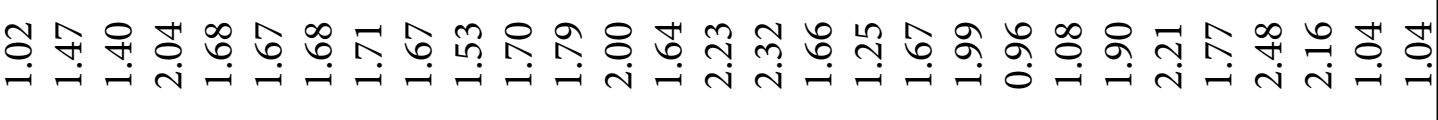 \\
\hline & 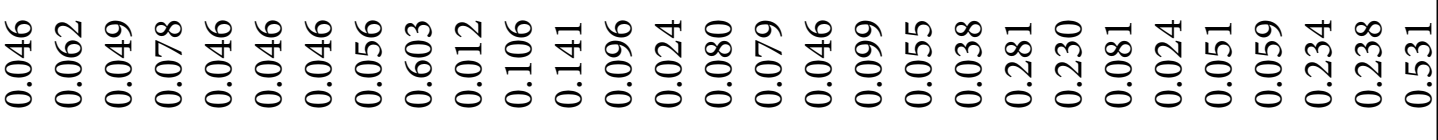 \\
\hline & 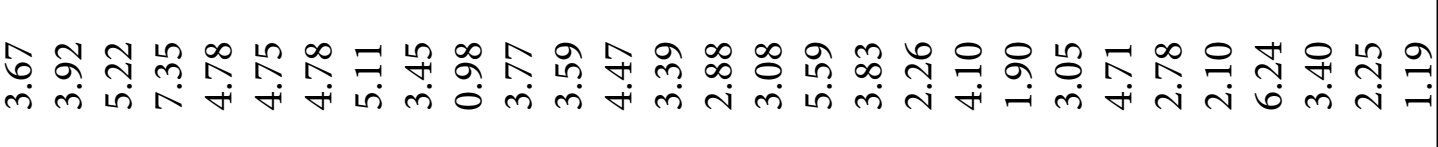 \\
\hline & 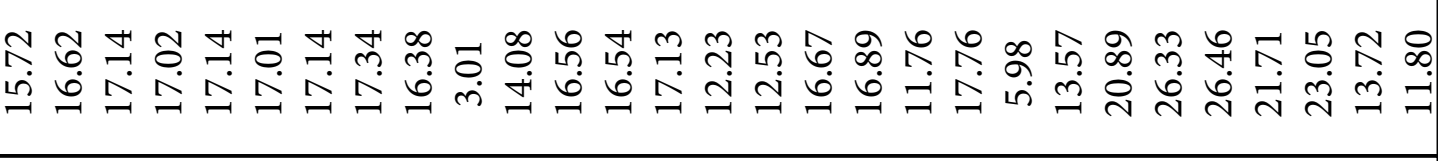 \\
\hline & 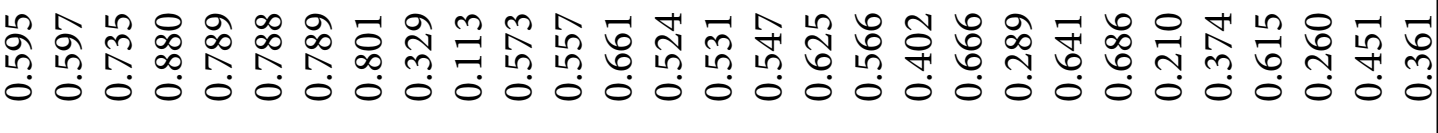 \\
\hline & 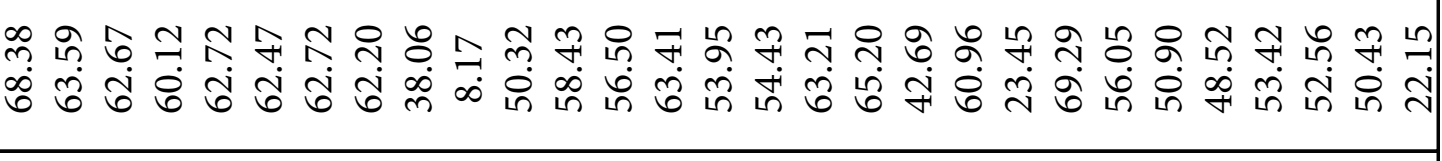 \\
\hline & 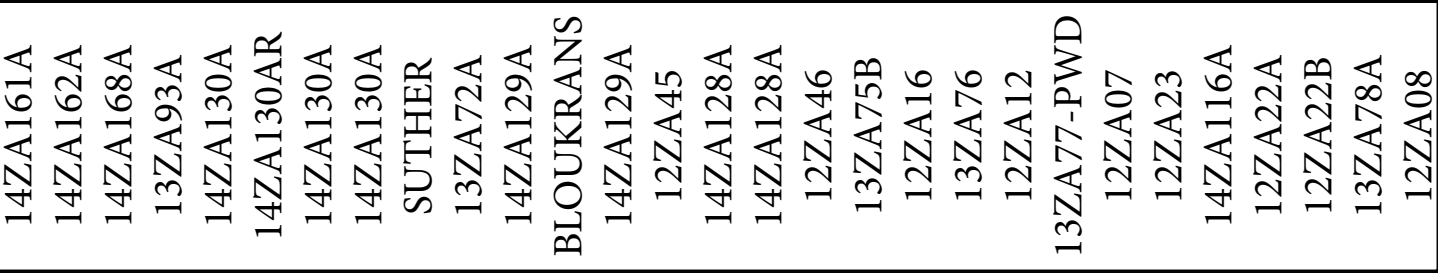 \\
\hline
\end{tabular}




\begin{tabular}{|c|c|}
\hline$\Xi$ & 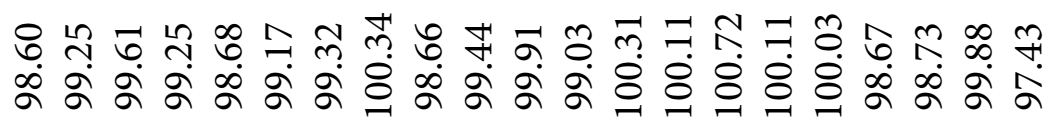 \\
\hline 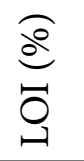 & 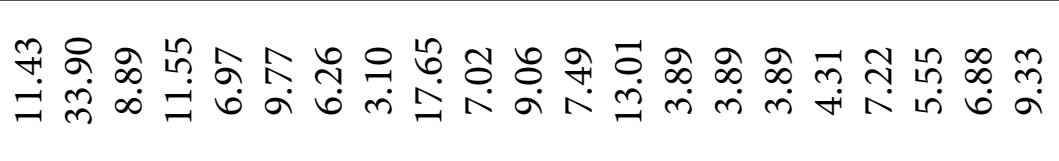 \\
\hline$a^{2 n}$ & 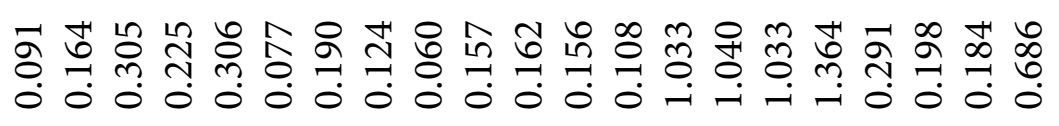 \\
\hline $\begin{array}{c}\overbrace{\tilde{Z}}^{N} \\
\stackrel{Z}{Z}^{2}\end{array}$ & 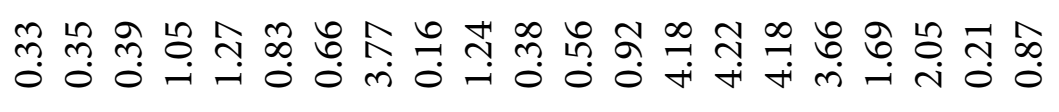 \\
\hline$\overbrace{n}^{\mathfrak{O}}$ & 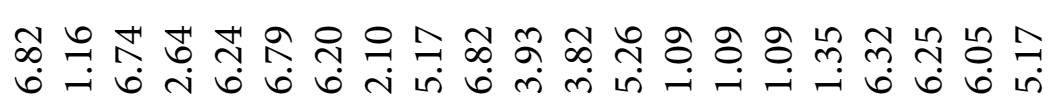 \\
\hline$\underset{ֶ}{ֶ}$ & 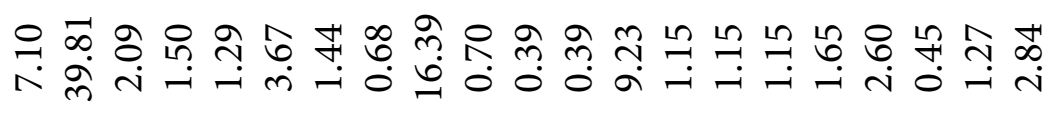 \\
\hline$\sum_{\substack{\infty \\
\infty}}^{\infty}$ & ○ 유 \\
\hline$\stackrel{\varrho}{\Xi}$ & 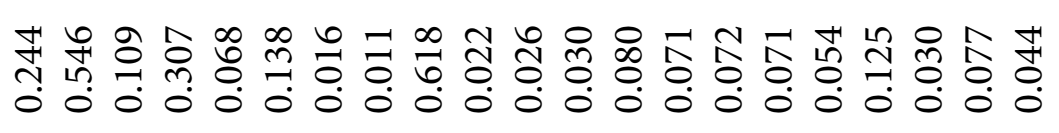 \\
\hline 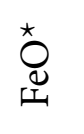 & 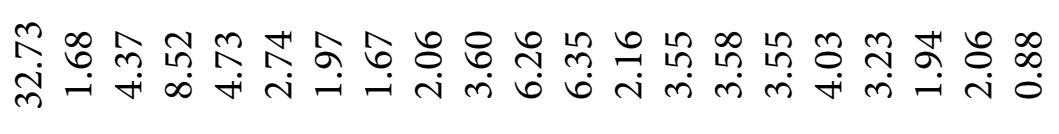 \\
\hline$\frac{O^{m}}{\sum^{N}}$ & 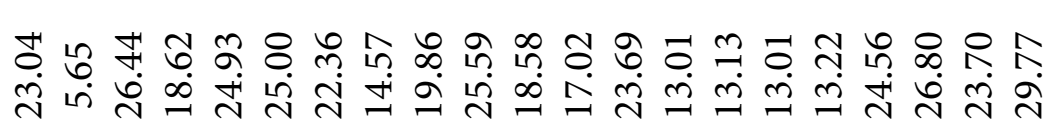 \\
\hline$\bigcap_{i=1}^{N}$ & 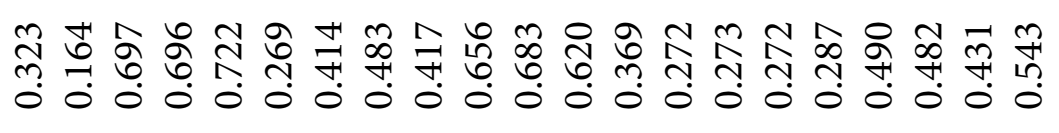 \\
\hline $0^{2}$ & 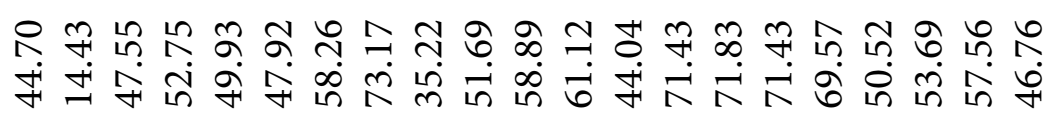 \\
\hline 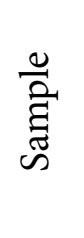 & 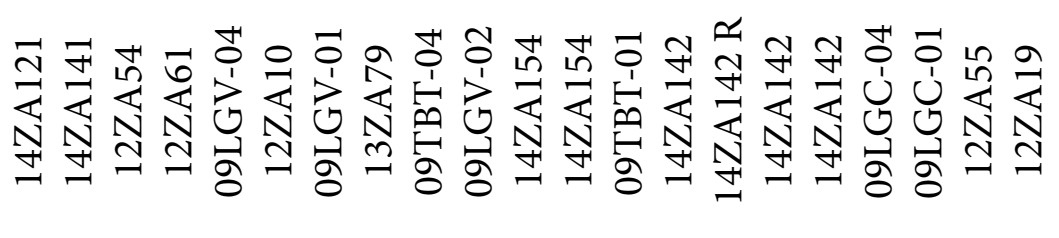 \\
\hline
\end{tabular}




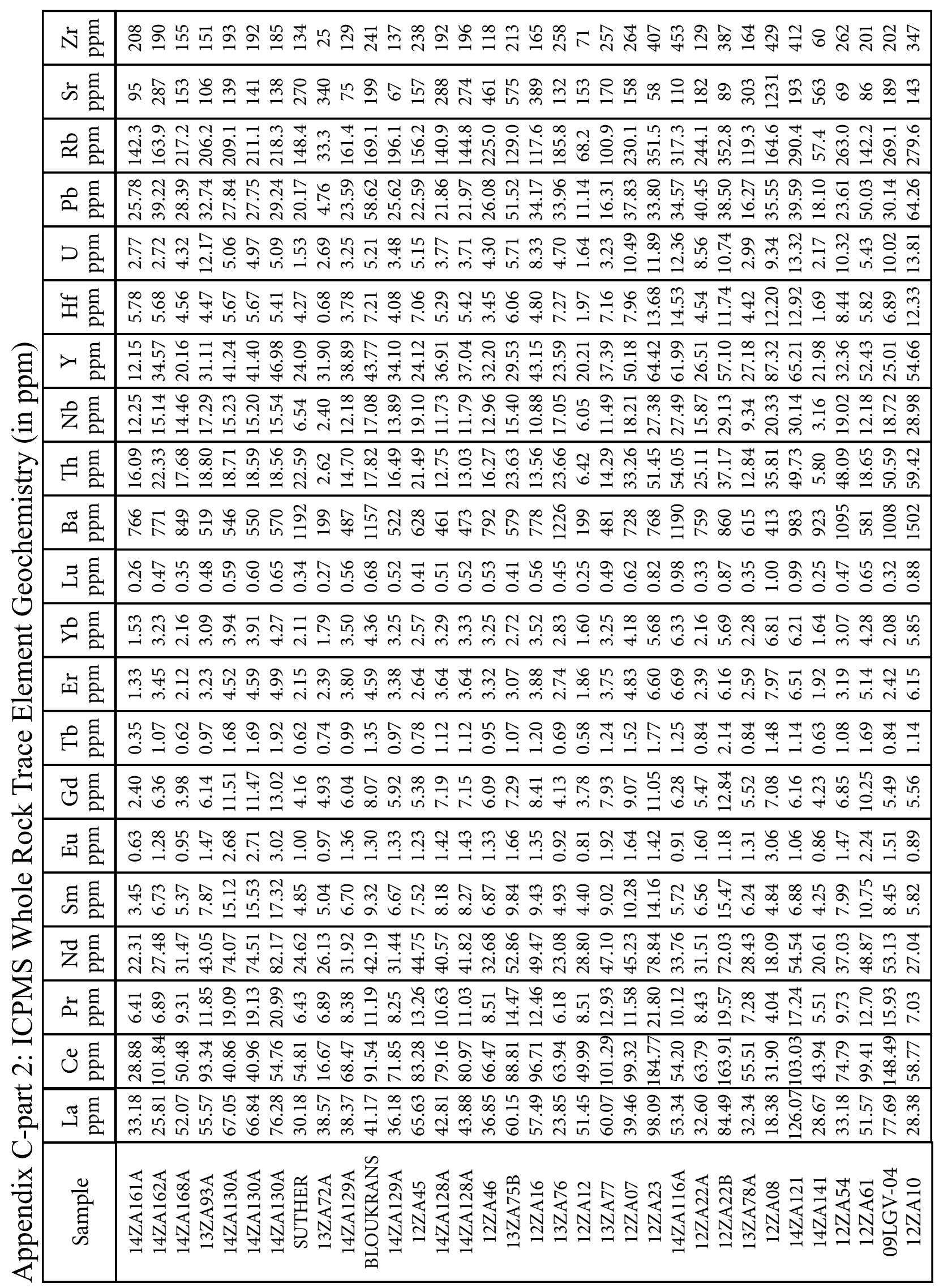




\begin{tabular}{|c|c|}
\hline 츨 & 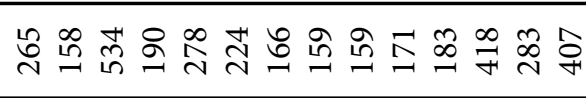 \\
\hline के हี & 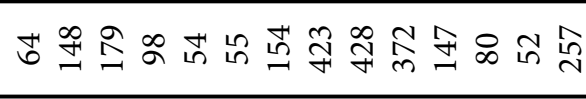 \\
\hline 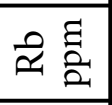 & 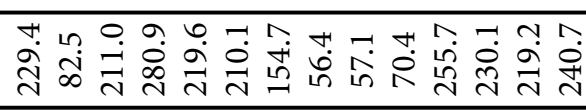 \\
\hline 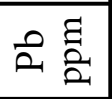 & 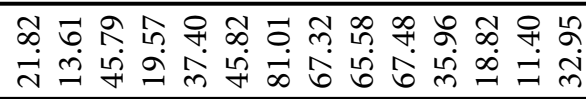 \\
\hline$\triangleright$ ฉ & 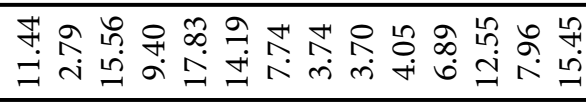 \\
\hline 荘芯 & 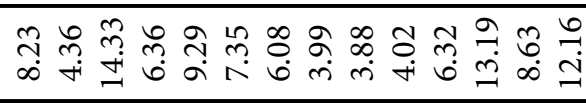 \\
\hline 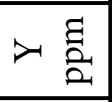 & 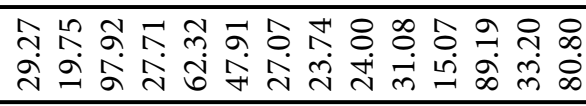 \\
\hline Z言 & 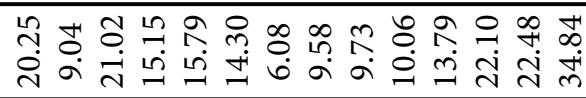 \\
\hline F辞 & 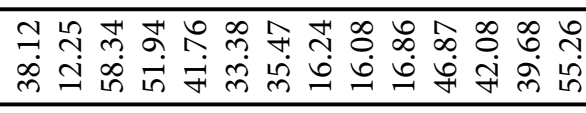 \\
\hline 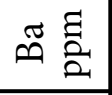 & 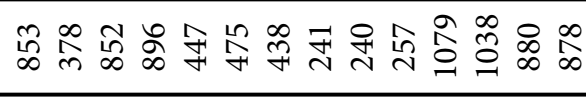 \\
\hline 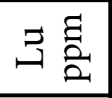 & 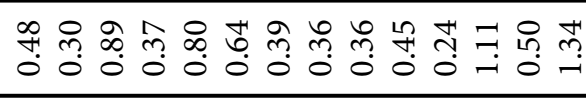 \\
\hline 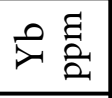 & 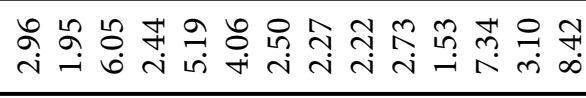 \\
\hline 穴层 & 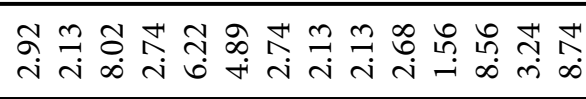 \\
\hline م嗼 & 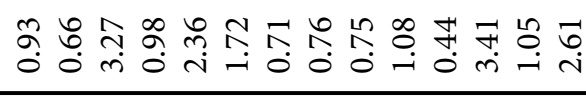 \\
\hline రુ ڤ̆ & 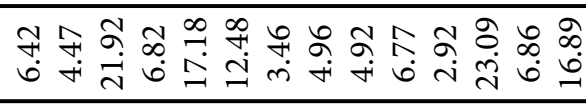 \\
\hline 函 & 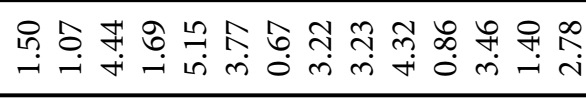 \\
\hline कี ڤี & 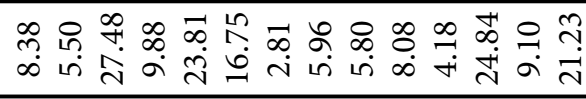 \\
\hline 乙ृa & 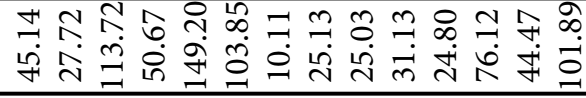 \\
\hline ڤ 芯 & 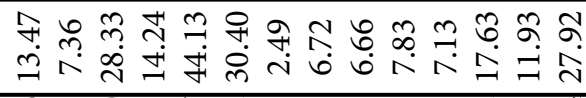 \\
\hline 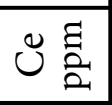 & 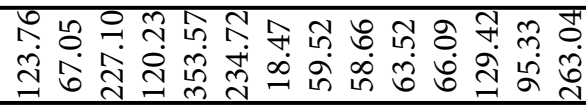 \\
\hline 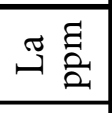 & 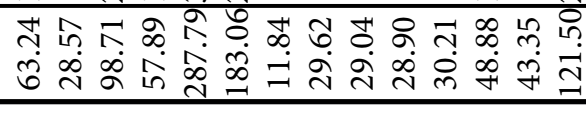 \\
\hline$\frac{\mathscr{\Xi}}{\text { हี }}$ & 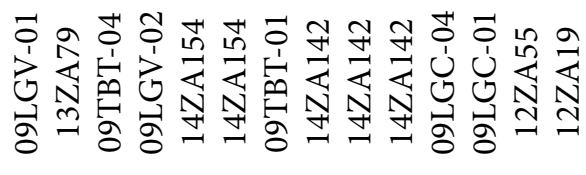 \\
\hline
\end{tabular}




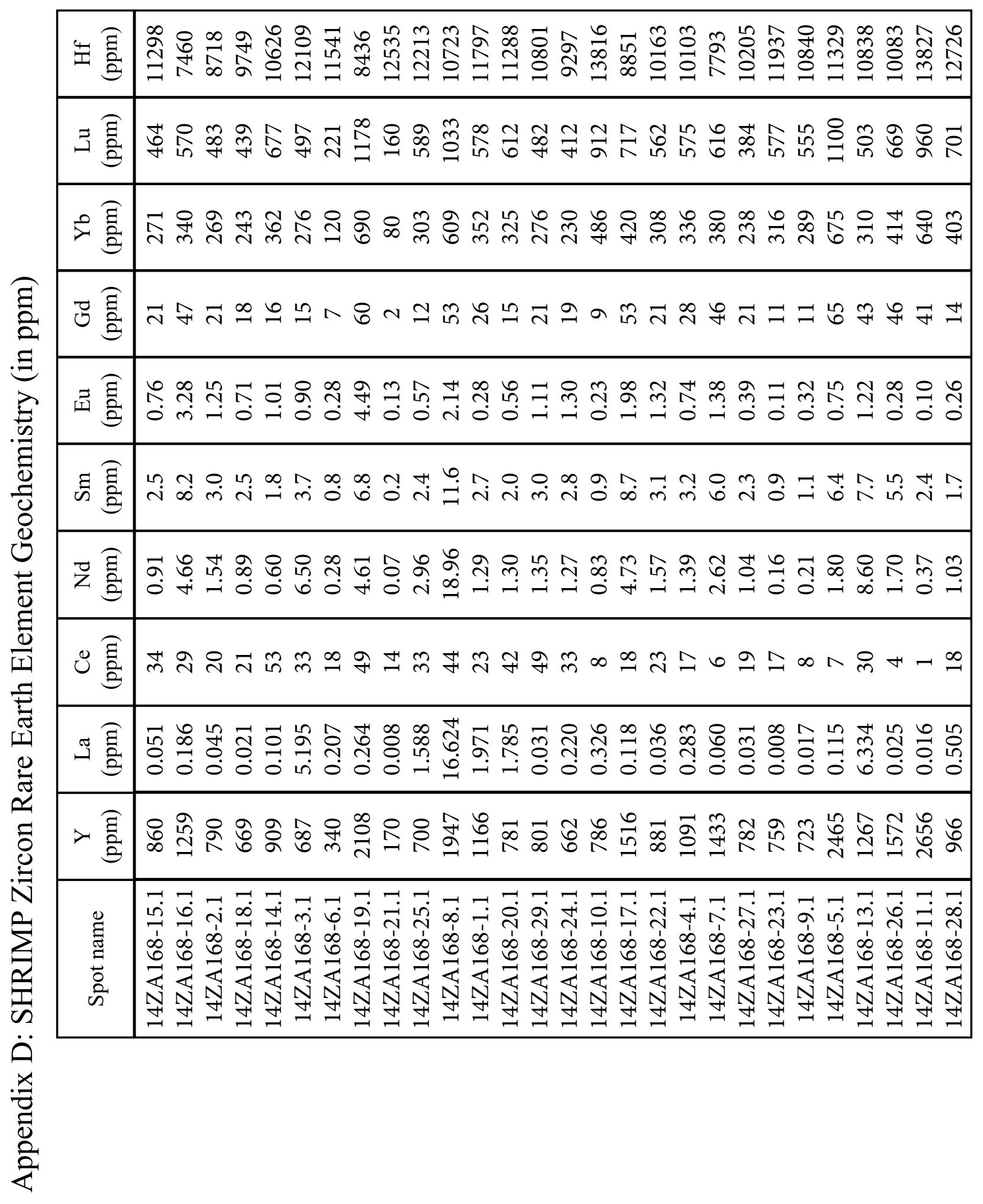




\begin{tabular}{|c|c|c|}
\hline & 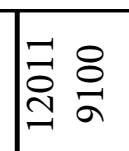 & 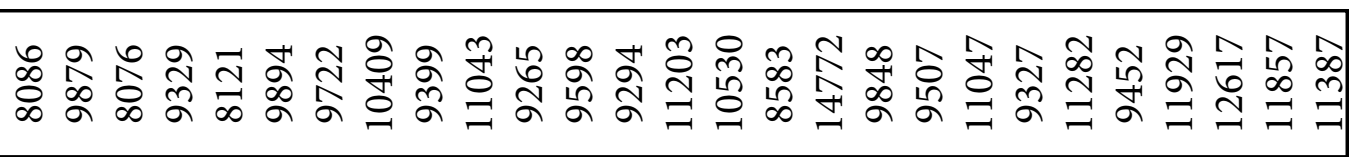 \\
\hline & 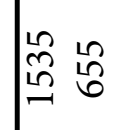 & 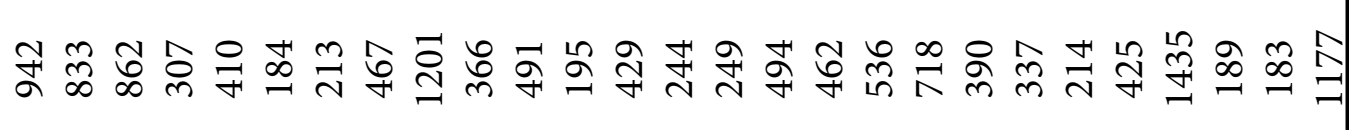 \\
\hline ट्र & $\mathbb{R}_{0}^{\circ}$ 号 & 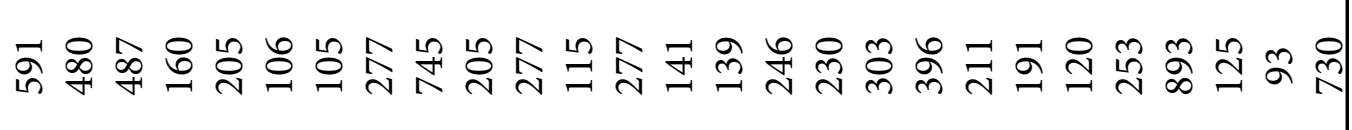 \\
\hline & in 8 & 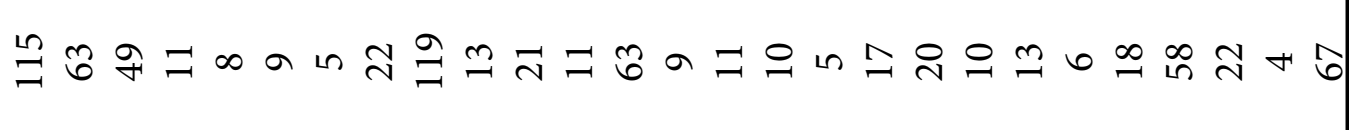 \\
\hline & 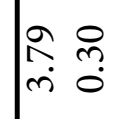 & 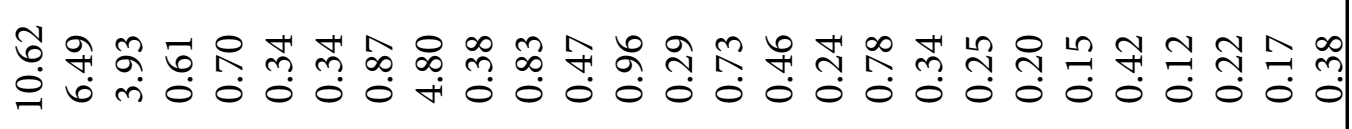 \\
\hline है & 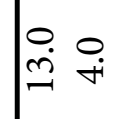 & 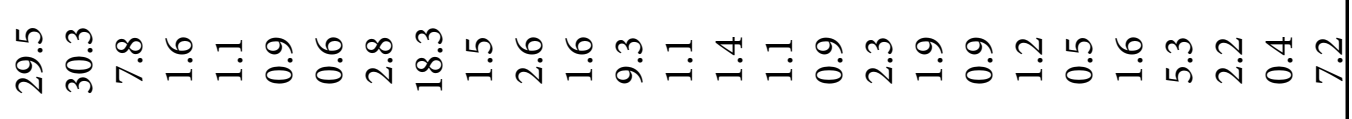 \\
\hline & 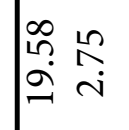 & 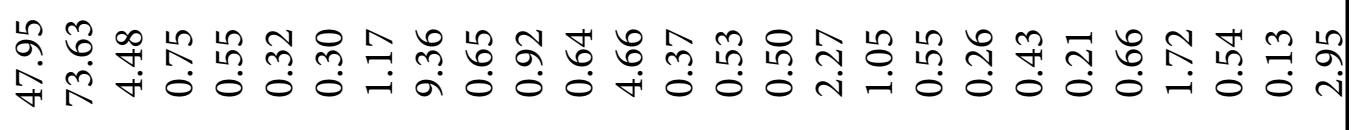 \\
\hline 8 言 & 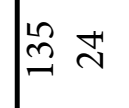 & 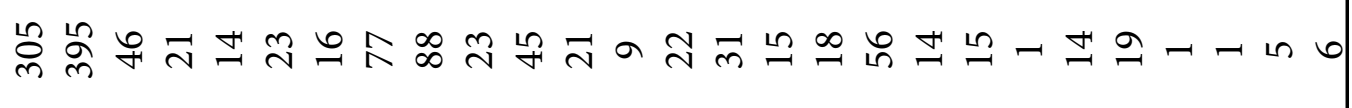 \\
\hline & 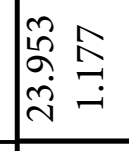 & 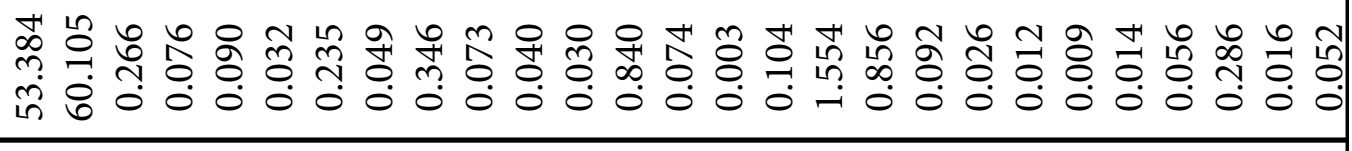 \\
\hline$>\widehat{\bar{\partial}}$ & 哑 & 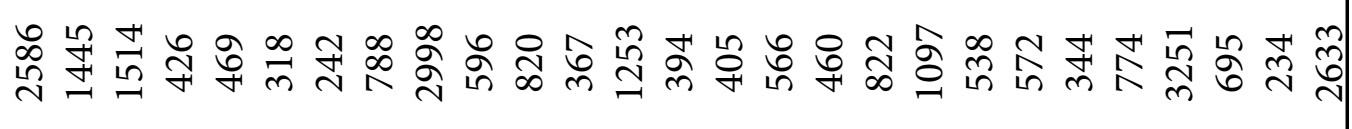 \\
\hline 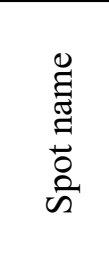 & 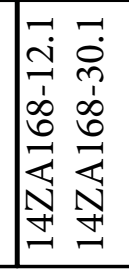 & 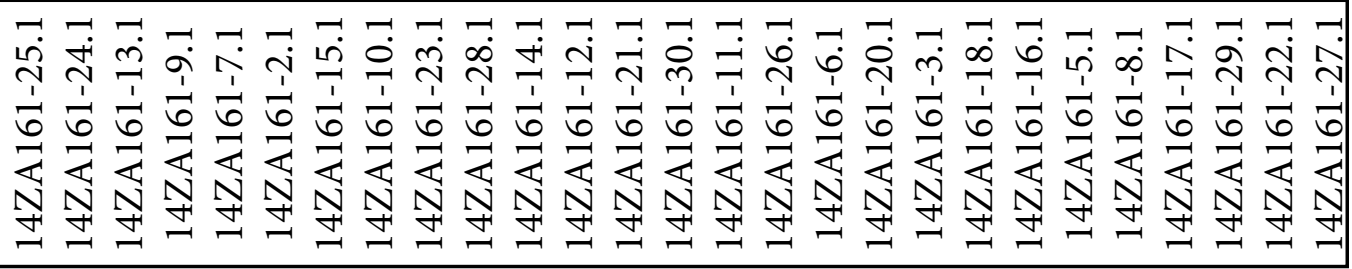 \\
\hline
\end{tabular}




\begin{tabular}{|c|c|c|c|c|}
\hline 丰言 & م⿸广巳 & 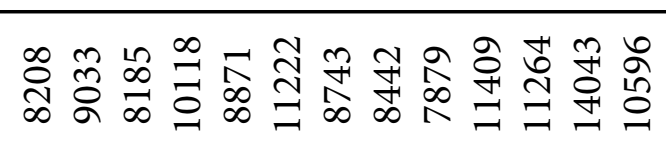 & 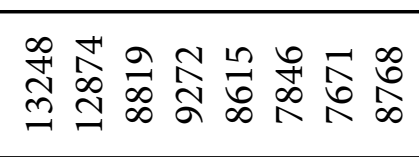 & 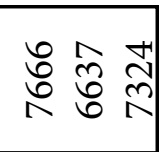 \\
\hline ज产 & 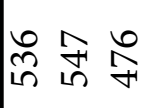 & 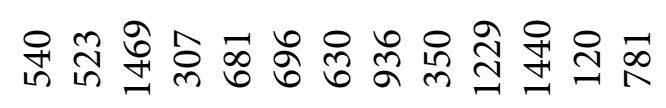 & 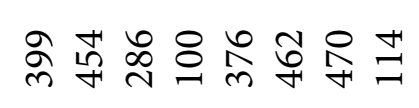 & 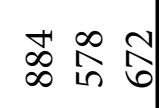 \\
\hline 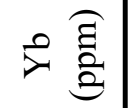 & î̀ & 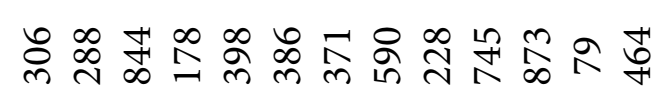 & 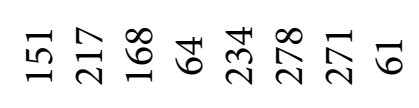 & 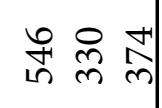 \\
\hline 도잉 & $\leadsto 2$ & q 尺 & 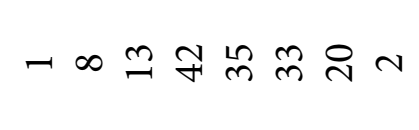 & 羊苏 \\
\hline 田高 & 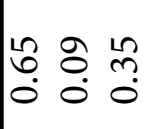 & 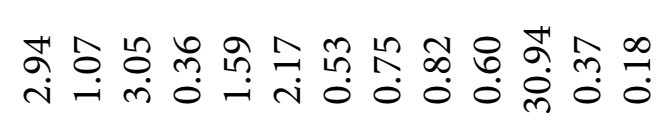 & 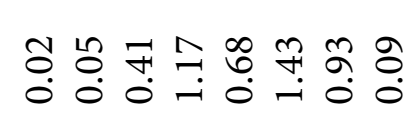 & 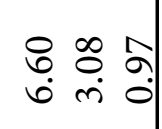 \\
\hline 㤩 言 & $\exists$ 논 녹 & 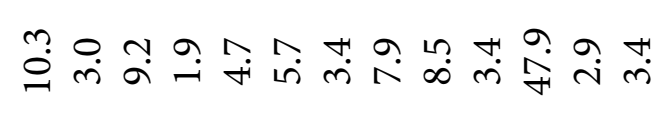 & 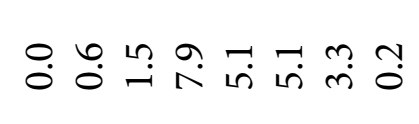 & $\stackrel{\infty}{\stackrel{\infty}{\sim}} \underset{\sim}{m}$ \\
\hline 艺言 & 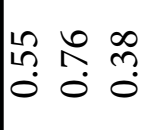 & 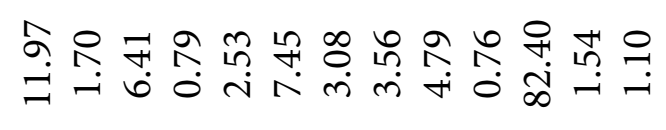 & 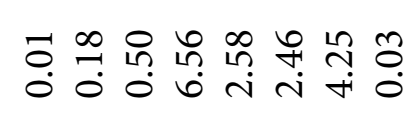 & $\stackrel{0}{\dot{\infty}} \stackrel{0}{\rightarrow}=$ \\
\hline ن 竒 & $2+\exists$ & 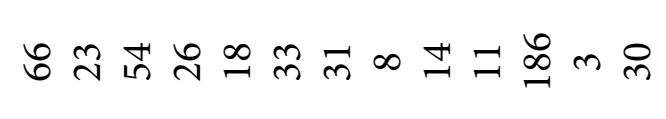 & 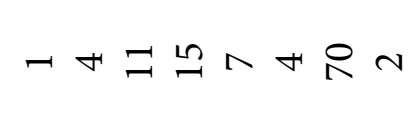 & 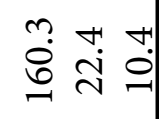 \\
\hline 恶 & \begin{tabular}{ll}
0 \\
\hdashline \\
0 \\
0 \\
0
\end{tabular} & 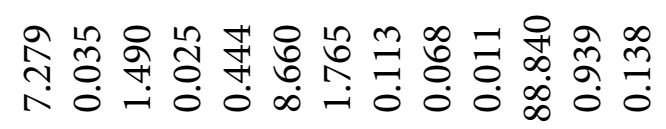 & 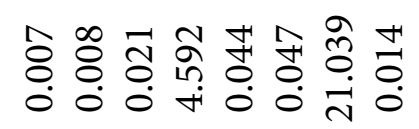 & 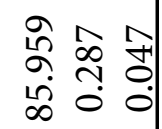 \\
\hline$\succ \widehat{\bar{a}}$ & 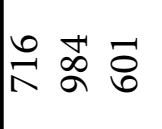 & 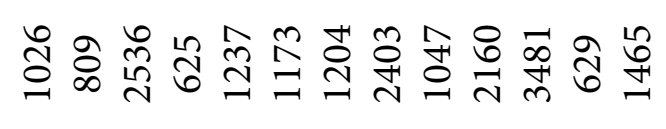 & 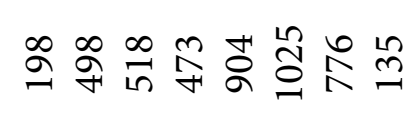 & $\stackrel{\infty}{\sim} \stackrel{\infty}{=} \stackrel{n}{=}$ \\
\hline 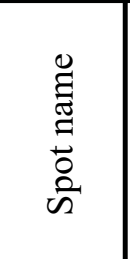 & 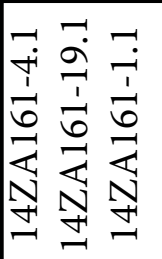 & 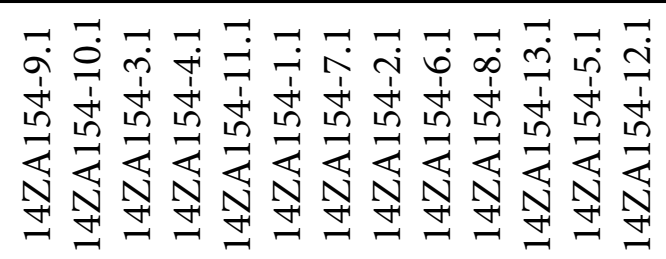 & 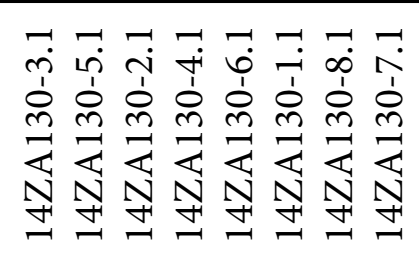 & 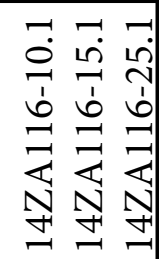 \\
\hline
\end{tabular}




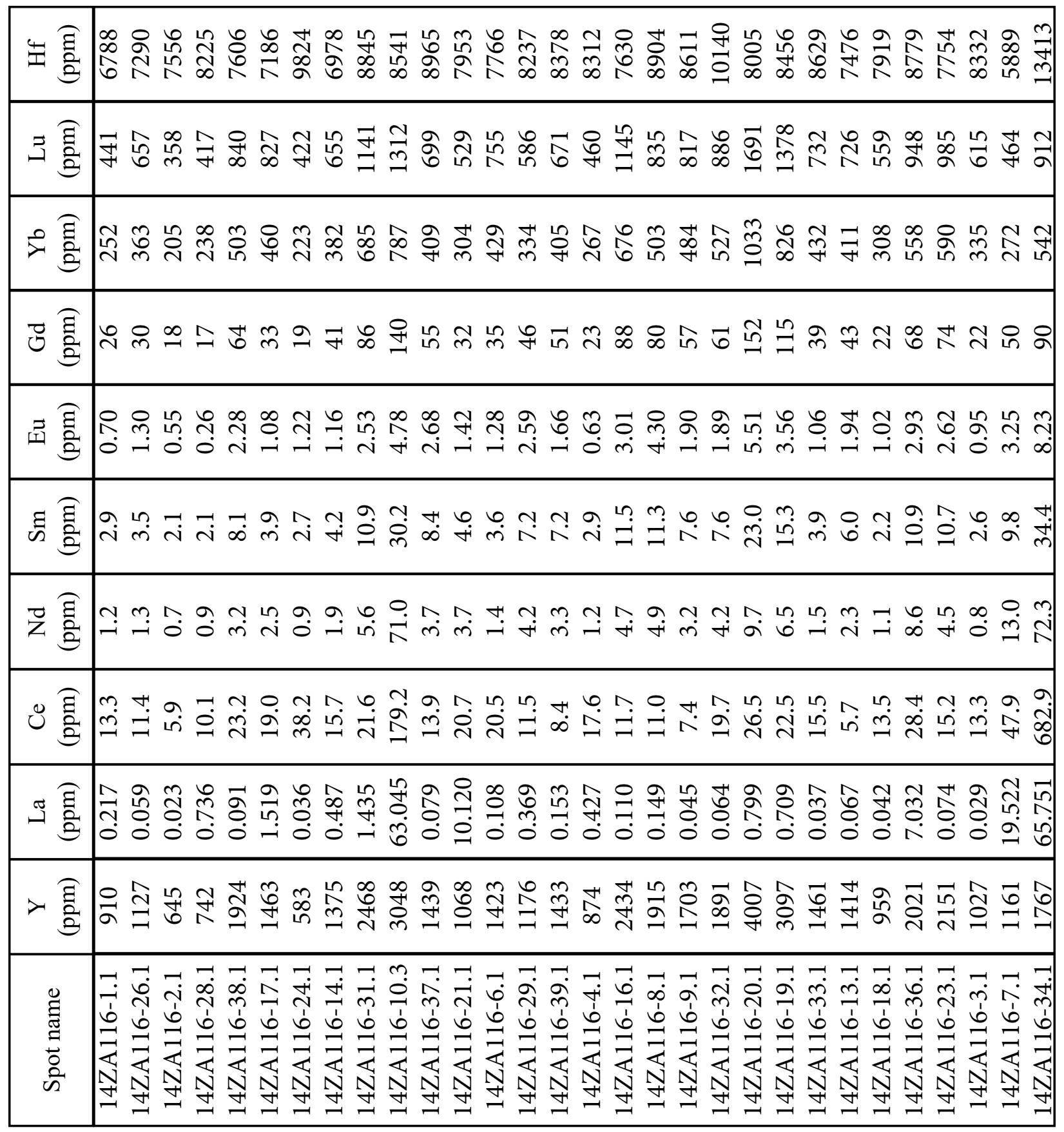




\begin{tabular}{|c|c|c|}
\hline & 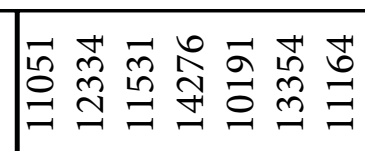 & 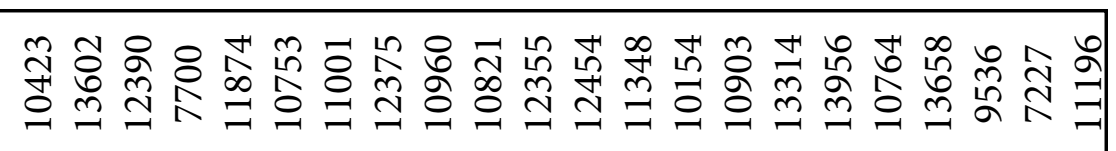 \\
\hline & 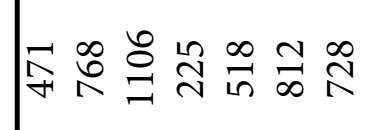 & 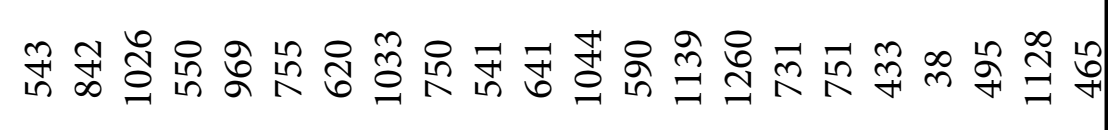 \\
\hline & 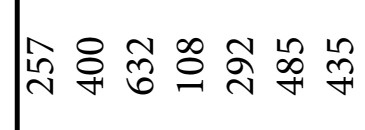 & 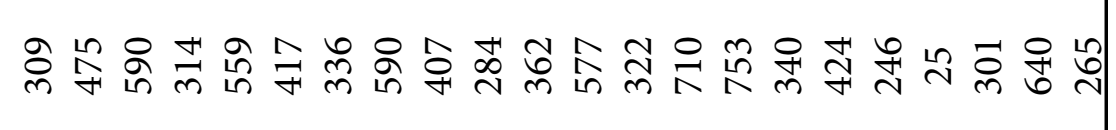 \\
\hline 已 言 & 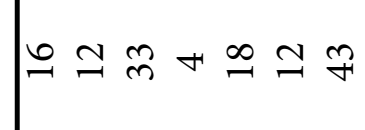 & $\stackrel{\infty}{\sim}$ 아 유 넹 \\
\hline & 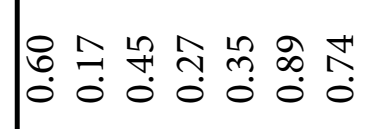 & ત゙્ \\
\hline ह & 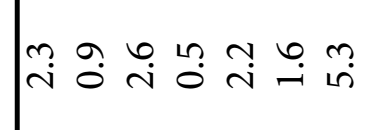 & 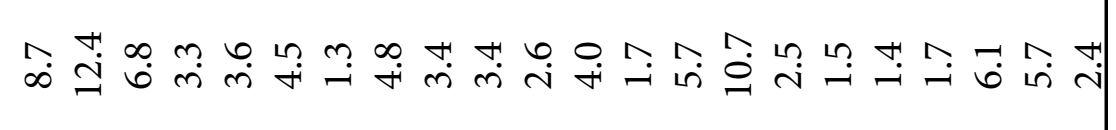 \\
\hline 夽言 & 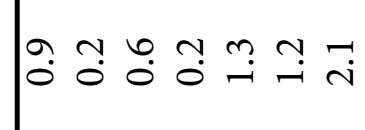 & 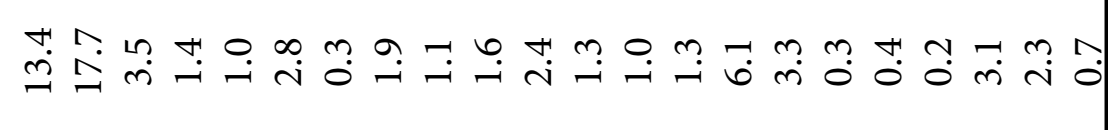 \\
\hline 。 & 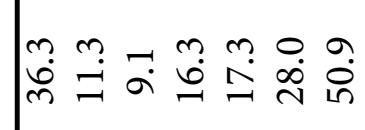 & 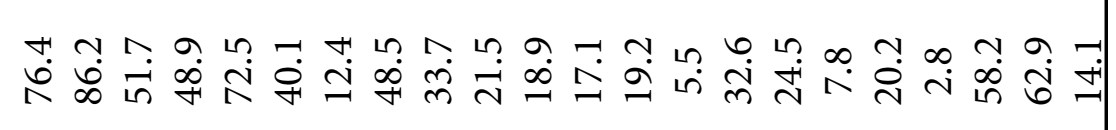 \\
\hline$\Im$ 言 & 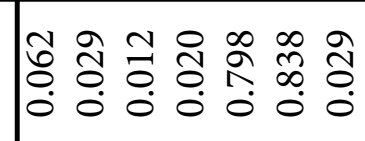 & 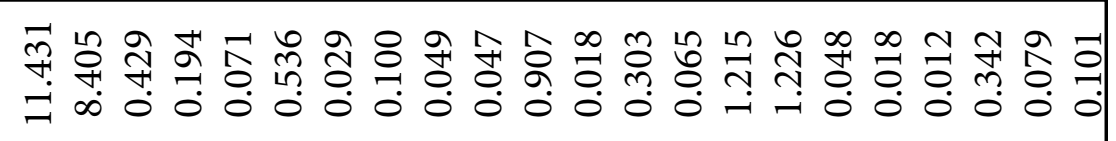 \\
\hline$>\widehat{\bar{~}}$ & 윳긍 & 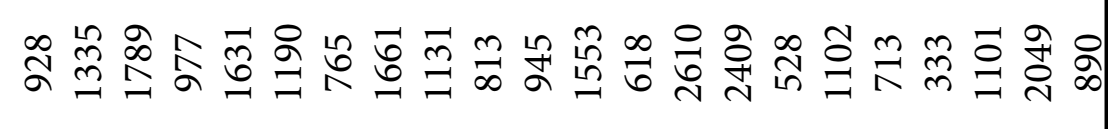 \\
\hline 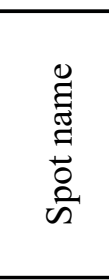 & 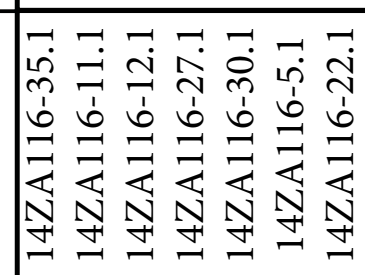 & 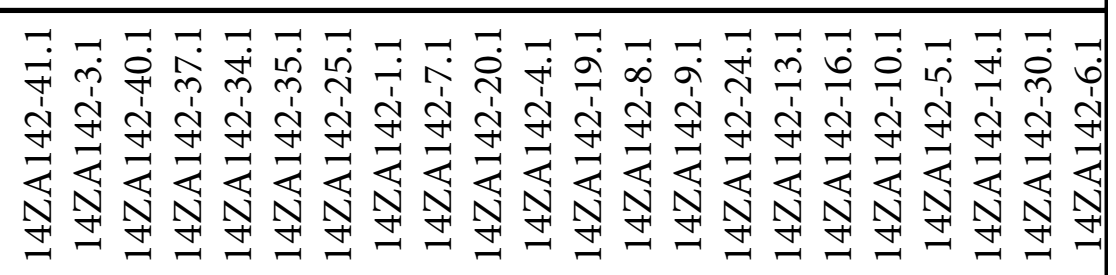 \\
\hline
\end{tabular}




\begin{tabular}{|c|c|c|c|}
\hline 出 & 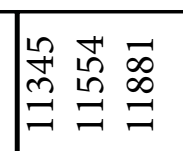 & 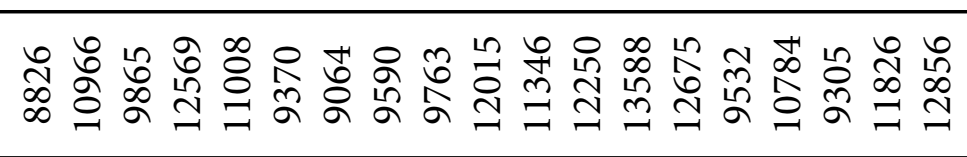 & 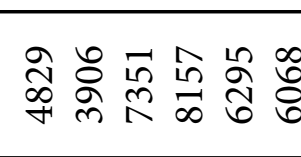 \\
\hline$\Xi \overline{\mathrm{E}}$ & 迅 & 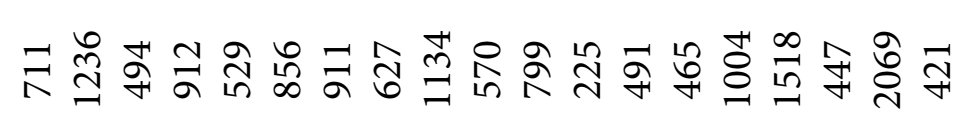 & স \\
\hline 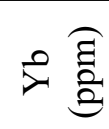 & 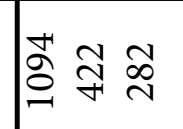 & 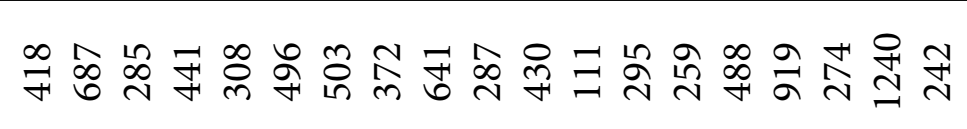 & 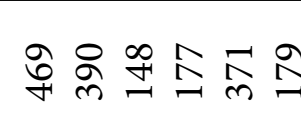 \\
\hline 己 言 & $\hat{0} \stackrel{\circ}{n}=$ & చি & 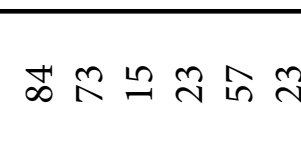 \\
\hline 当产 & 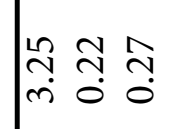 & 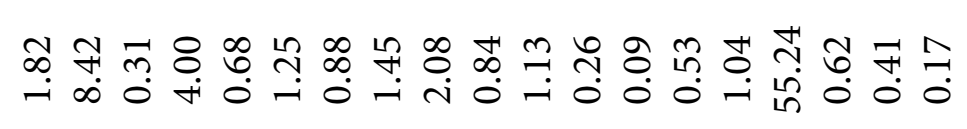 & 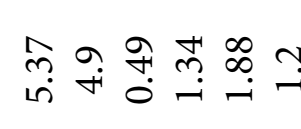 \\
\hline 局 & 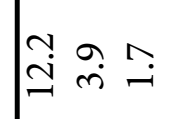 & 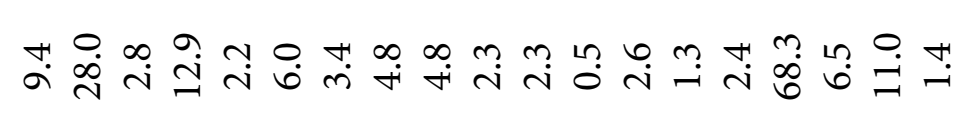 & 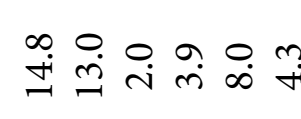 \\
\hline 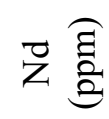 & $\stackrel{m}{\because}=\stackrel{0}{0}$ & 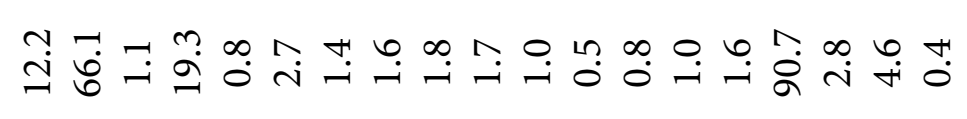 & 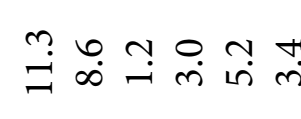 \\
\hline ¿ & 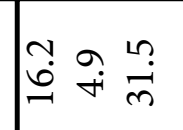 & 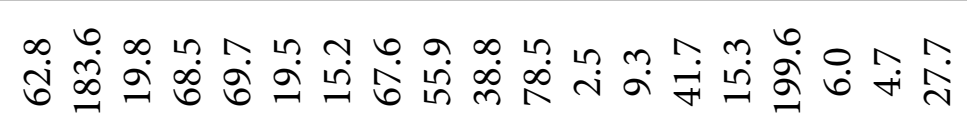 & $\underset{\sim}{\sharp}+\sigma \cong=$ \\
\hline 䨠 & 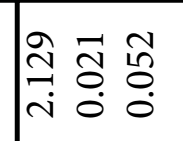 & 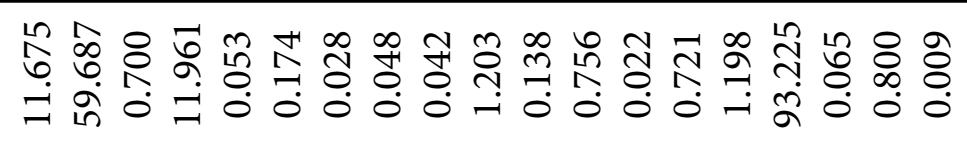 & 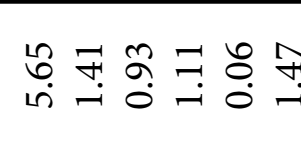 \\
\hline$>\widehat{\bar{z}}$ & 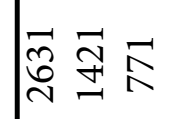 & 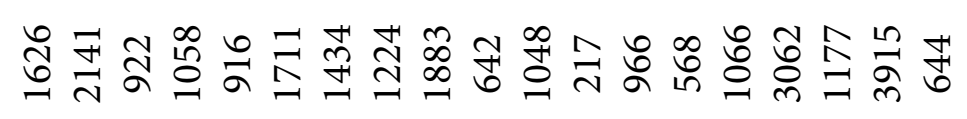 & 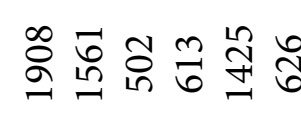 \\
\hline 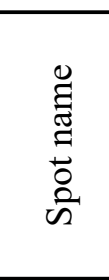 & 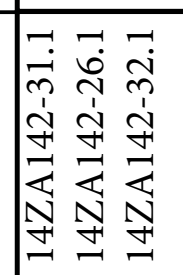 & 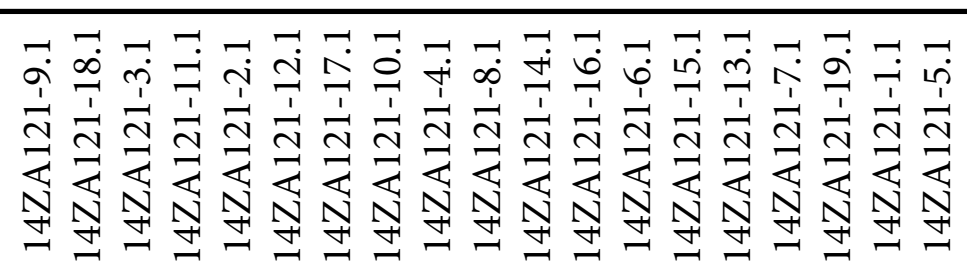 & 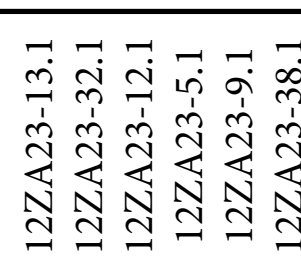 \\
\hline
\end{tabular}




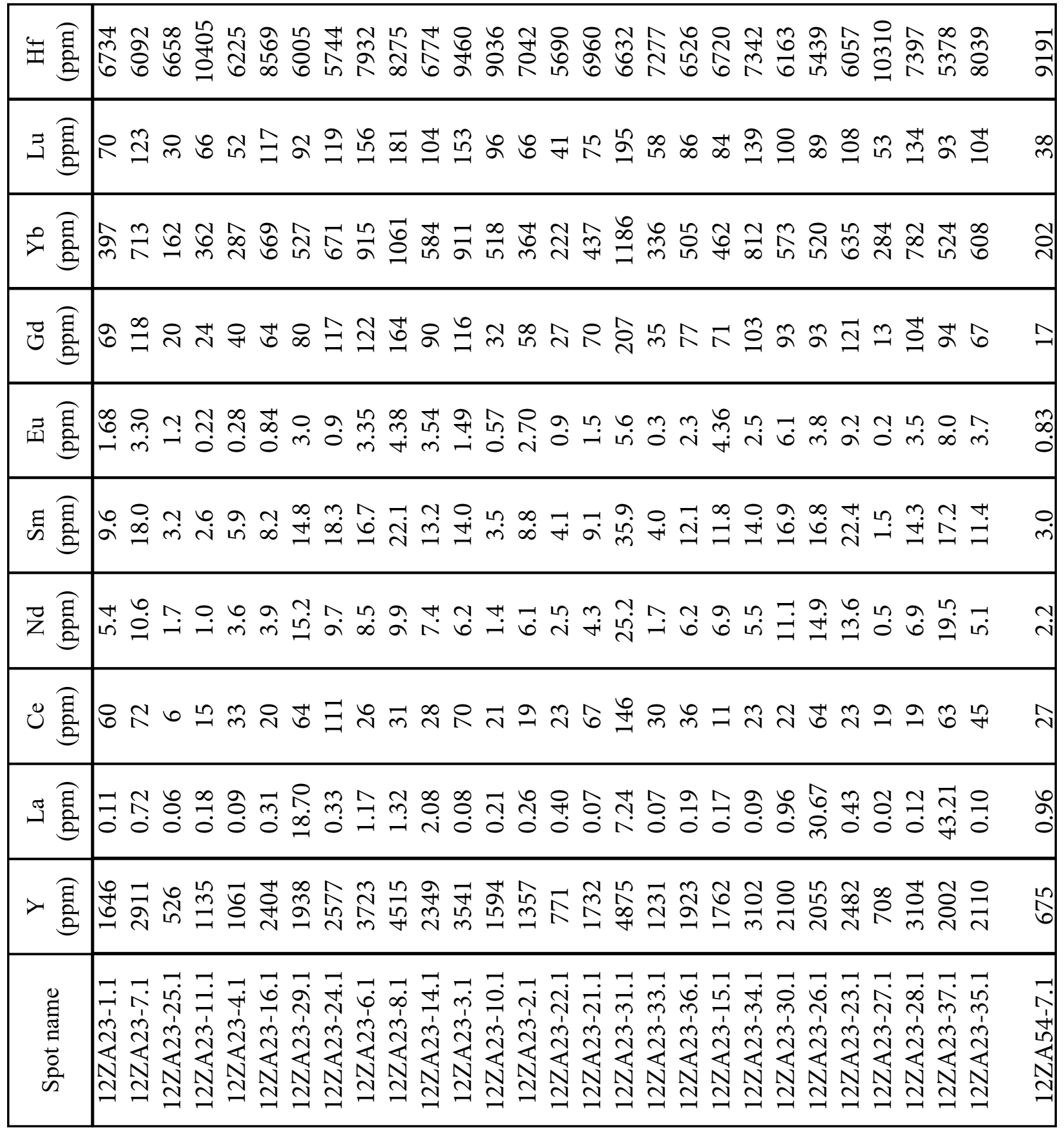




\begin{tabular}{|c|c|c|}
\hline 生言 & 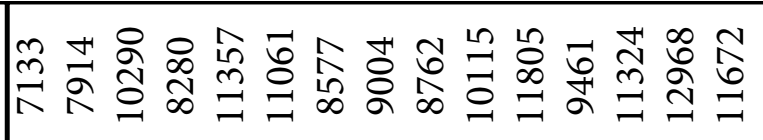 & 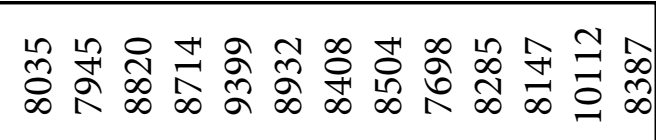 \\
\hline$\exists \widehat{\Xi}$ & 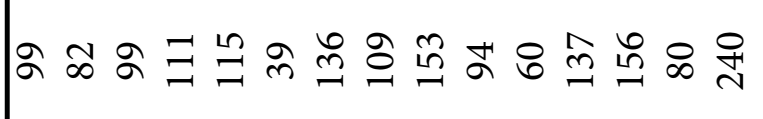 & 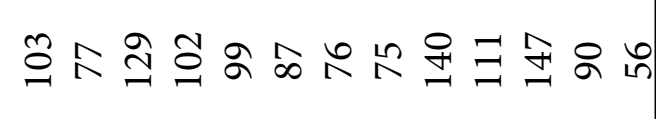 \\
\hline 맇ㅎㅇ & 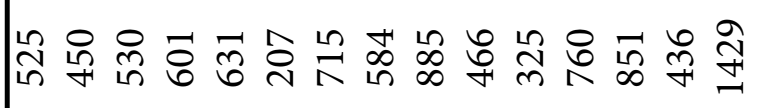 & 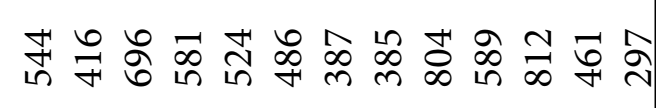 \\
\hline ¿ & 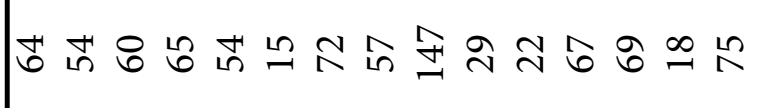 & 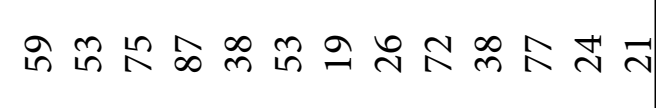 \\
\hline & 冓 & 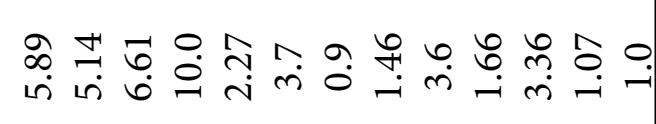 \\
\hline 咅 & 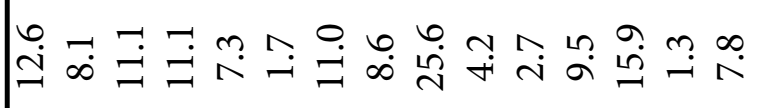 & 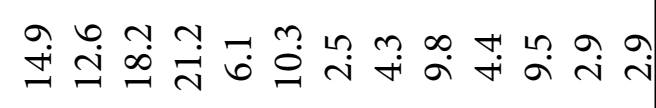 \\
\hline z $\overline{\mathrm{z}}$ & 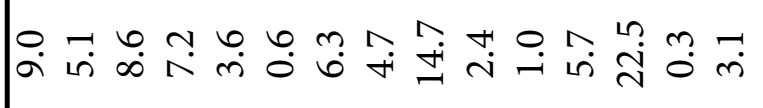 & 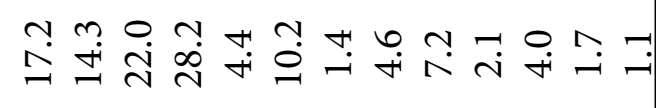 \\
\hline 8 홍 & 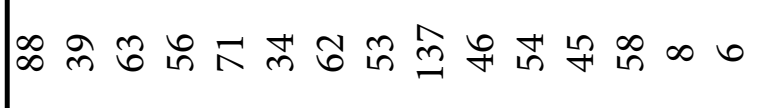 & 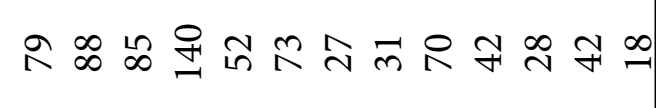 \\
\hline ฐ & 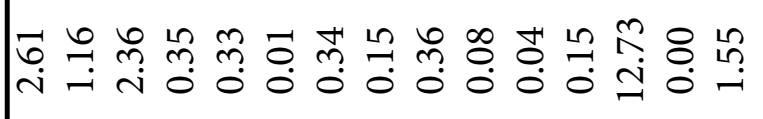 & 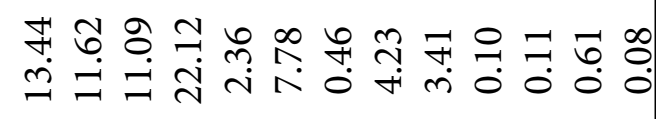 \\
\hline$\succ \widehat{\bar{~}}$ & 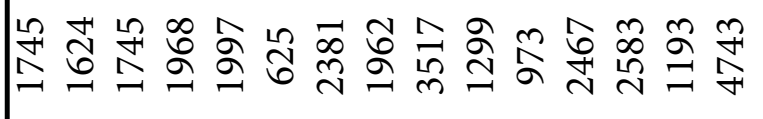 & 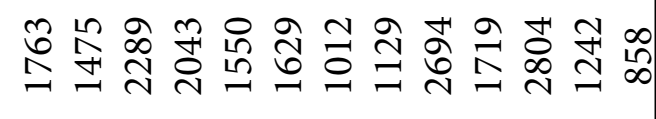 \\
\hline 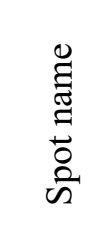 & 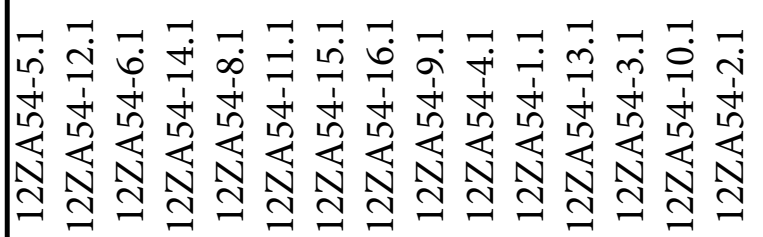 & 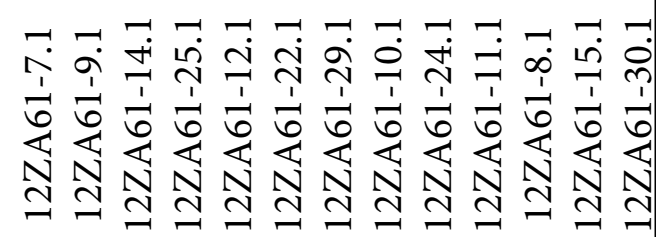 \\
\hline
\end{tabular}




\begin{tabular}{|c|c|c|}
\hline 出言 & 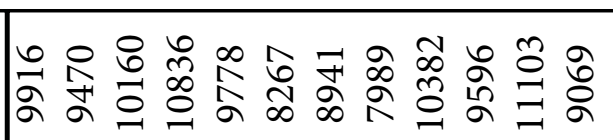 & 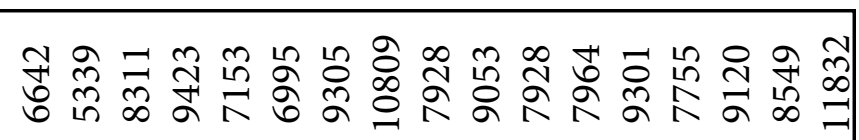 \\
\hline & œ & 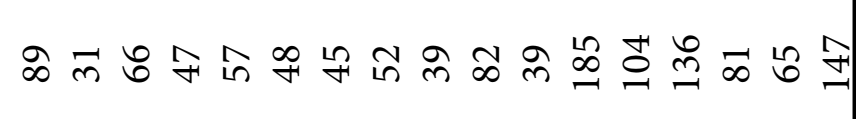 \\
\hline 글 & 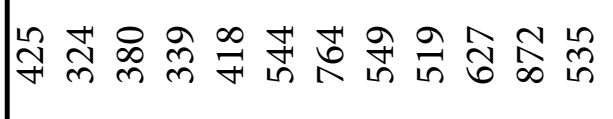 & 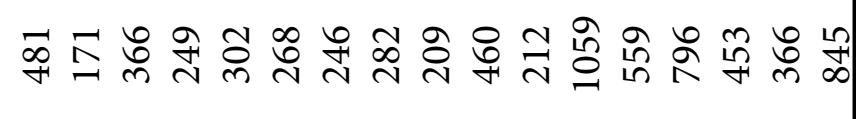 \\
\hline$\Xi$ & 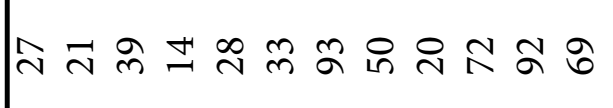 & 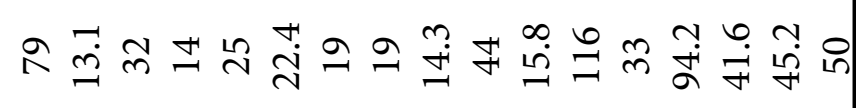 \\
\hline & 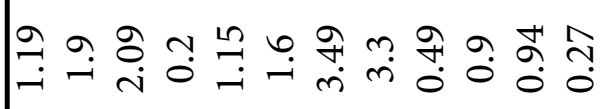 & 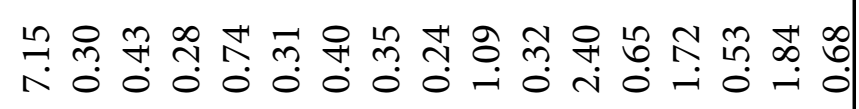 \\
\hline 홍 & 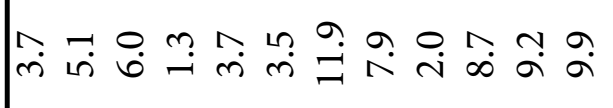 & 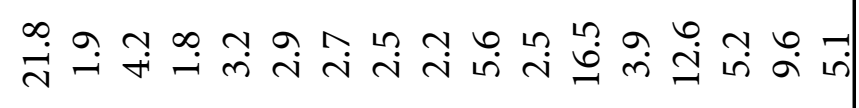 \\
\hline 艺言 & 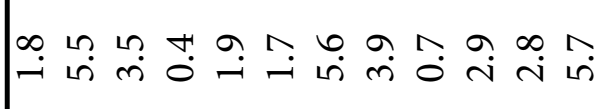 & 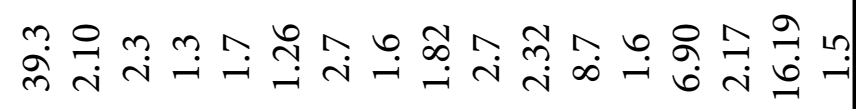 \\
\hline ن 言 & 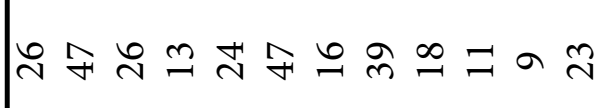 & 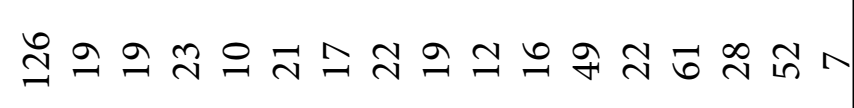 \\
\hline 咅 & 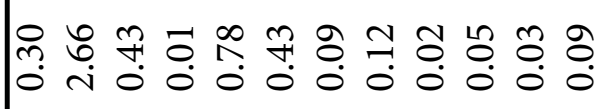 & 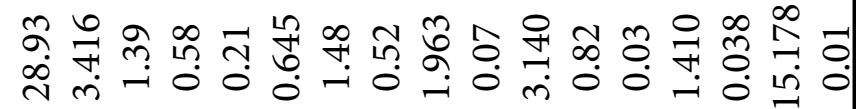 \\
\hline$\succ \widehat{\overline{\mathrm{a}}}$ & 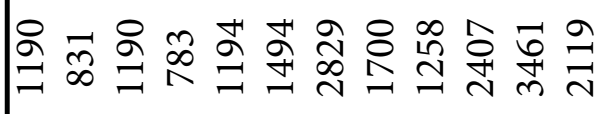 & 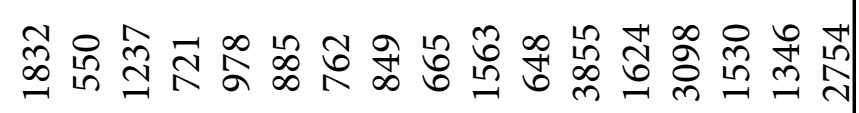 \\
\hline 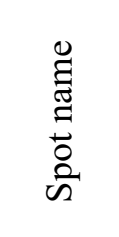 & 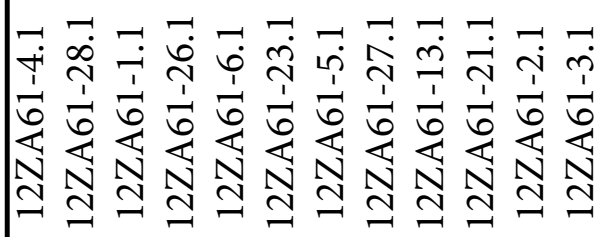 & 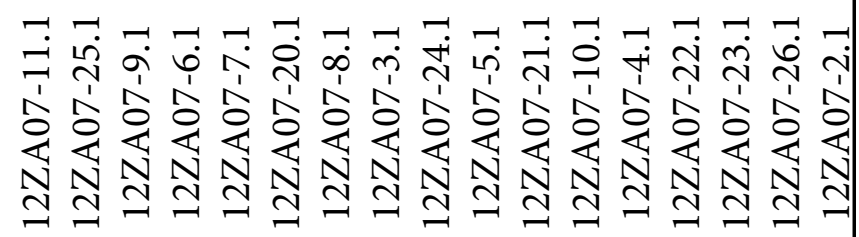 \\
\hline
\end{tabular}




\begin{tabular}{|c|c|c|c|c|}
\hline 生言 & $\begin{array}{l}3 \\
\infty \\
\infty \\
\infty\end{array}$ & 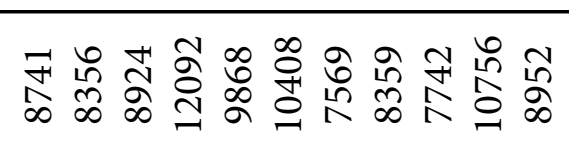 & 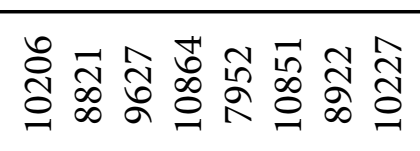 & 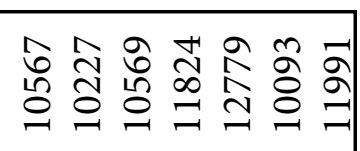 \\
\hline & in & 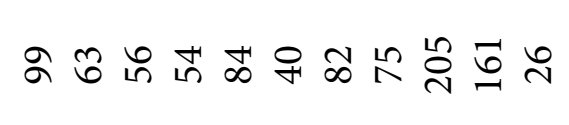 & $\because \exists$ タ & 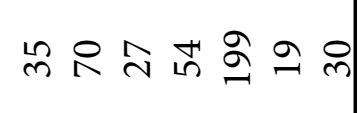 \\
\hline & స్ల & 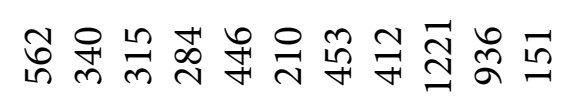 & 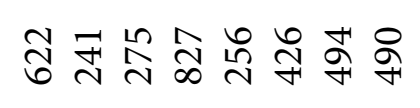 & 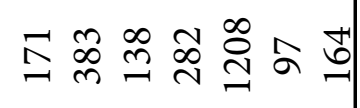 \\
\hline & $\stackrel{\infty}{+}$ & - & 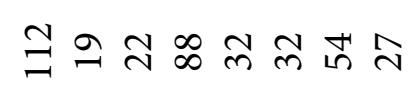 & 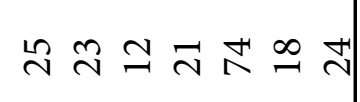 \\
\hline 㓙 言 & 落 & 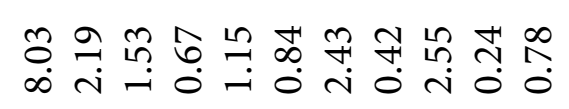 & 艿 & 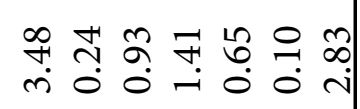 \\
\hline & $\begin{array}{l}n \\
6\end{array}$ & 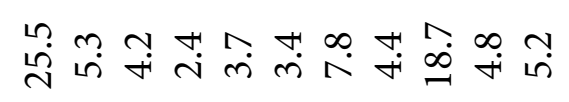 & 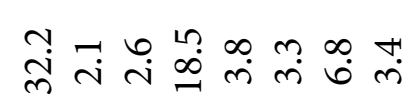 & 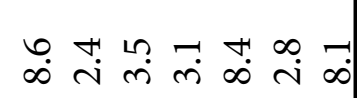 \\
\hline 艺言 & $\stackrel{n}{m}$ & 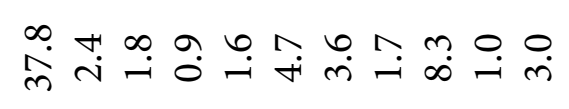 & 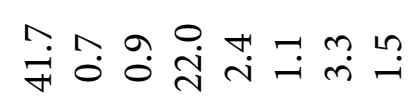 & 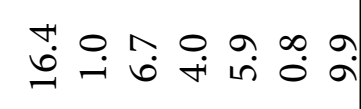 \\
\hline $0 \widehat{\bar{z}}$ & 几 & 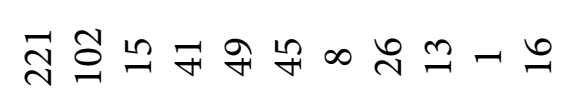 & 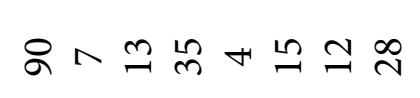 & 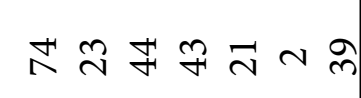 \\
\hline 言 & ${ }_{0}^{0}$ & 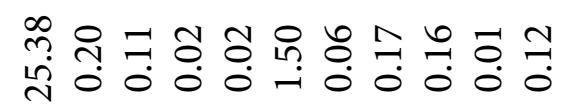 & 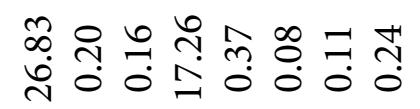 & 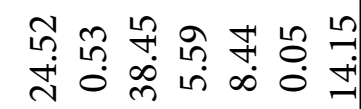 \\
\hline$>\widehat{\bar{~}}$ & 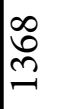 & 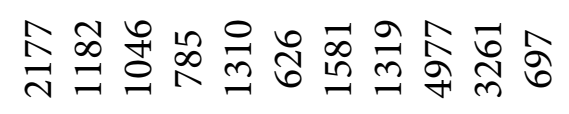 & 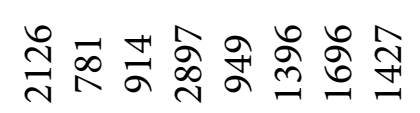 & 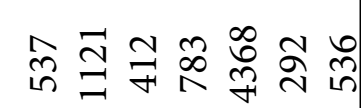 \\
\hline 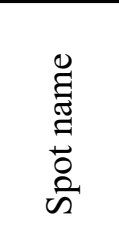 & 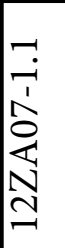 & 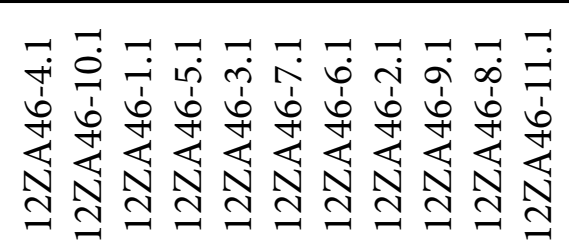 & 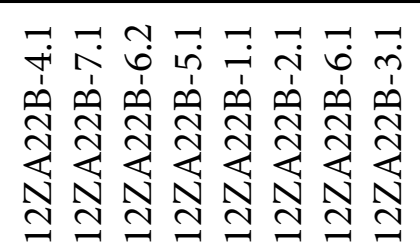 & 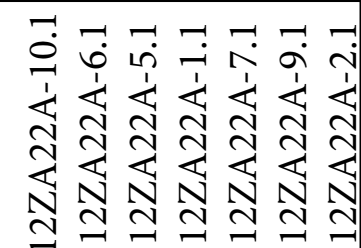 \\
\hline
\end{tabular}




\begin{tabular}{|c|c|c|c|}
\hline 生言 & مिે & $\begin{array}{l}\infty \\
\infty \\
\infty \\
0 \\
0 \\
0\end{array}$ & 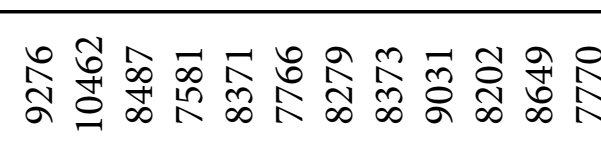 \\
\hline & $\infty \vec{m}$ & 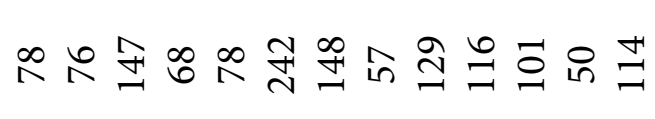 & 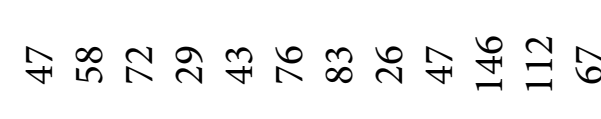 \\
\hline & 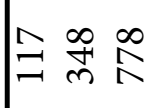 & 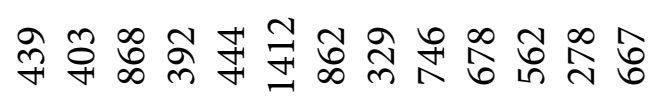 & 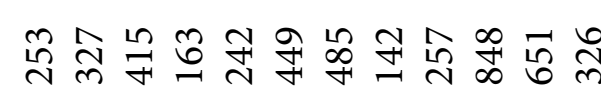 \\
\hline E & 농 & 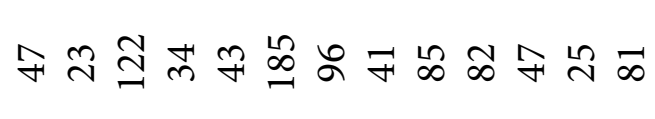 & 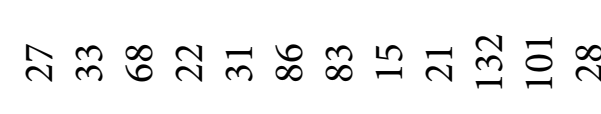 \\
\hline 灵言 & 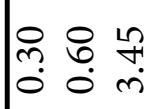 & 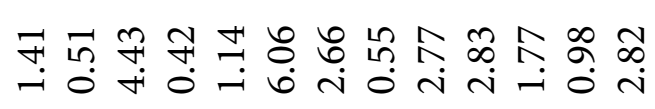 & 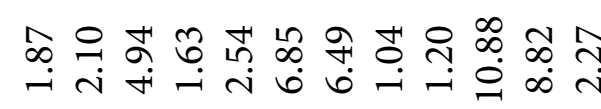 \\
\hline & $\vec{i} \underset{\sim}{\sim} \stackrel{n}{\infty}$ & 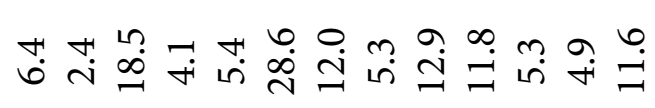 & m \\
\hline 艺言 & $\vec{i} \stackrel{\infty}{\infty} \stackrel{0}{\dot{0}}$ & 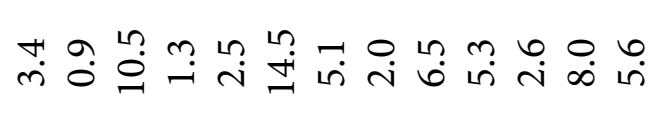 & 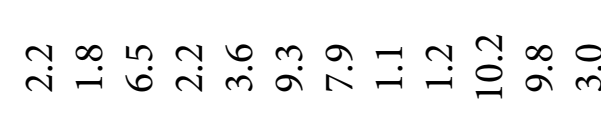 \\
\hline 8 言 & 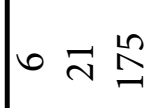 & 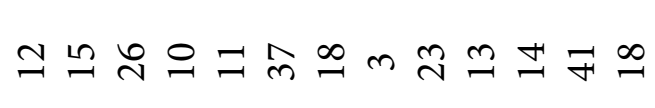 & 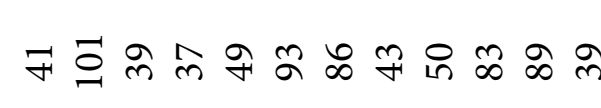 \\
\hline 言 & 至 & 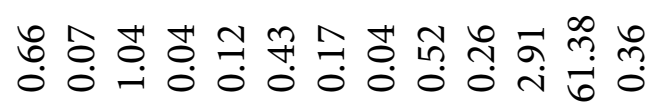 & 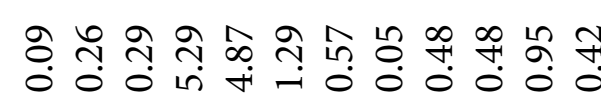 \\
\hline$>\widehat{\bar{z}}$ & 串总总 & 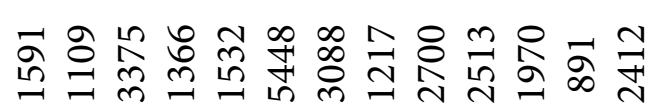 & 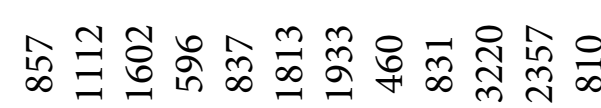 \\
\hline 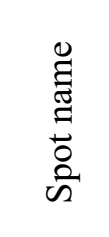 & 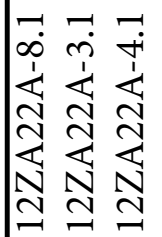 & 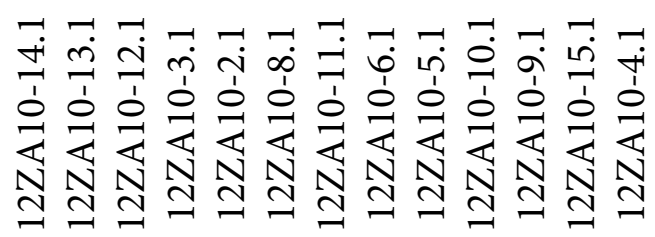 & 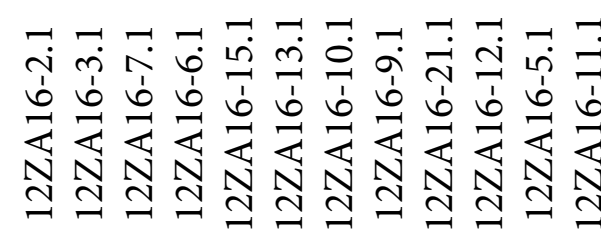 \\
\hline
\end{tabular}




\begin{tabular}{|c|c|c|c|}
\hline 生 言 & 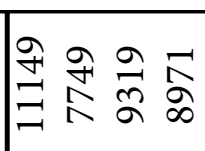 & 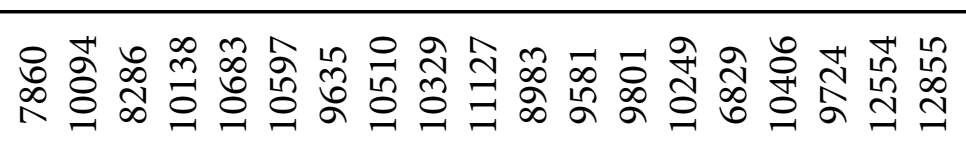 & 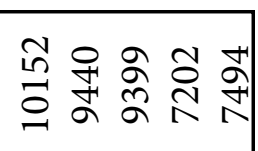 \\
\hline & 㶽 & 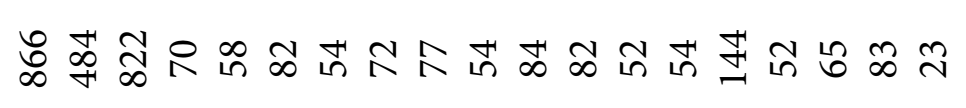 & 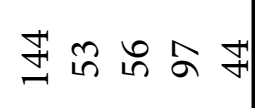 \\
\hline & 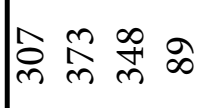 & 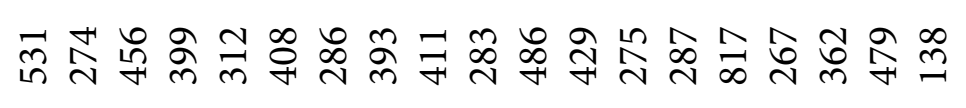 & 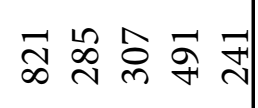 \\
\hline$\tilde{E}$ & is in F $\sigma$ & ద표 & $\underset{m}{m} \stackrel{n}{\sim}$ \\
\hline 屆 & 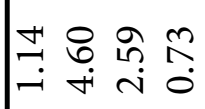 & 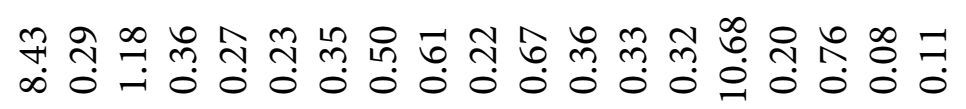 & 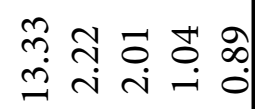 \\
\hline & min & 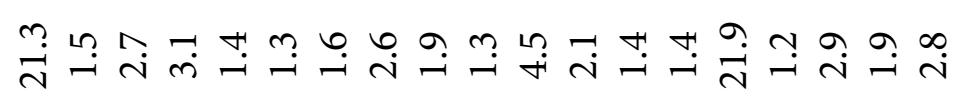 & 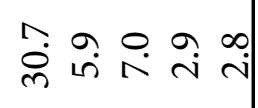 \\
\hline 艺言 & $\stackrel{\ln }{\rightarrow} \stackrel{n}{\wedge} \overrightarrow{0}$ & 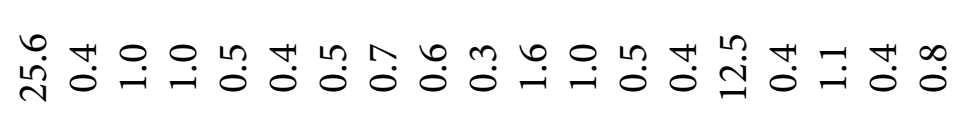 & 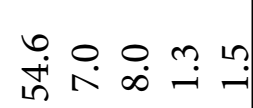 \\
\hline ○ 言 & 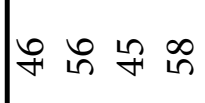 & \& & 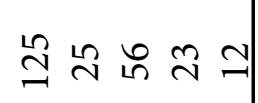 \\
\hline ฐ & 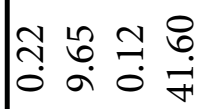 & 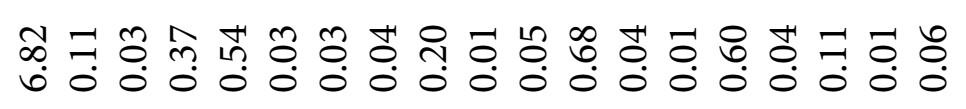 & 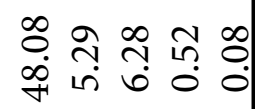 \\
\hline$\succ \widehat{\bar{~}}$ & 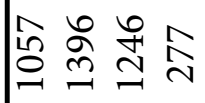 & 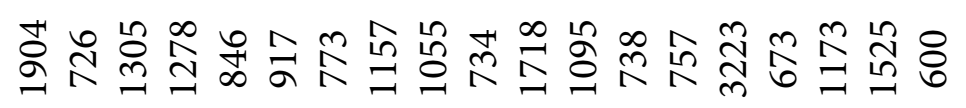 & 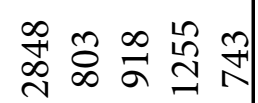 \\
\hline $\begin{array}{l}\text { ह } \\
\text { 흘 } \\
\text { के }\end{array}$ & 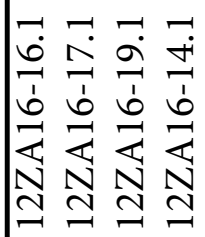 & 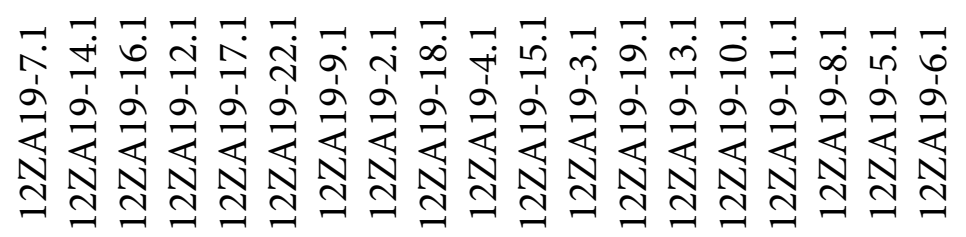 & 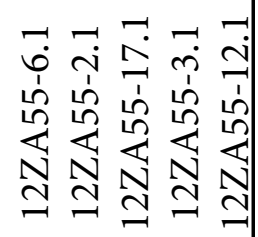 \\
\hline
\end{tabular}




\begin{tabular}{|c|c|c|}
\hline 出言 & 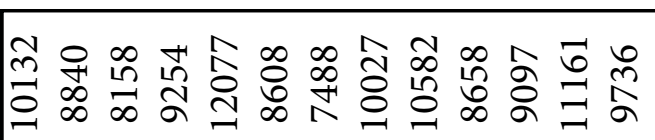 & 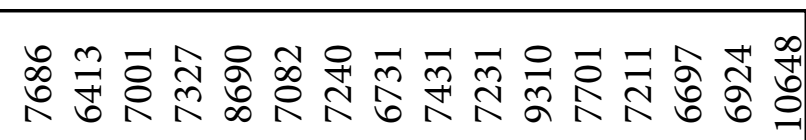 \\
\hline$\Xi$ 홍 & 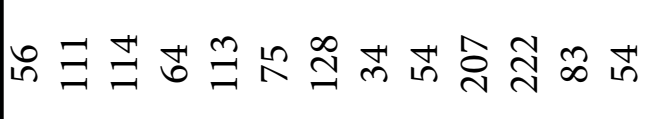 & 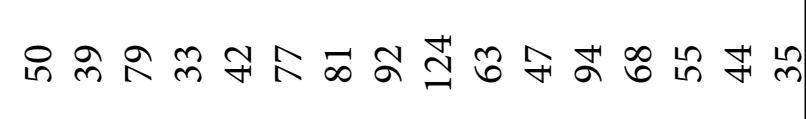 \\
\hline & 屏 & 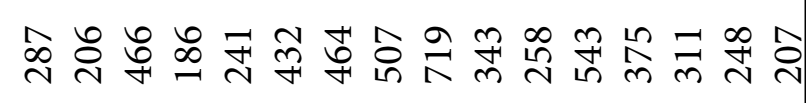 \\
\hline$\Xi$ & $\infty$ in & 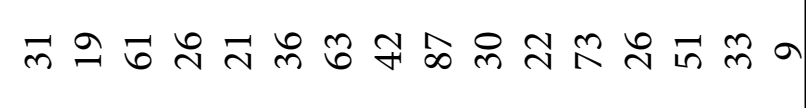 \\
\hline & ĥ & 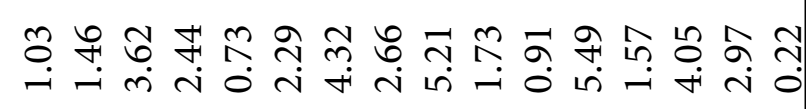 \\
\hline 曺言 & 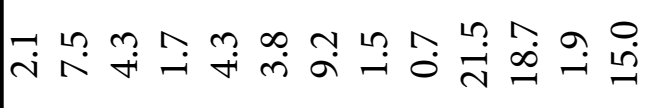 & 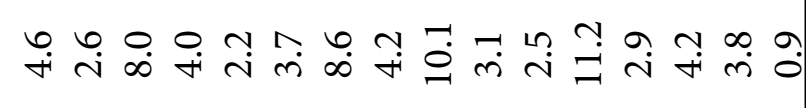 \\
\hline 艺 产 & 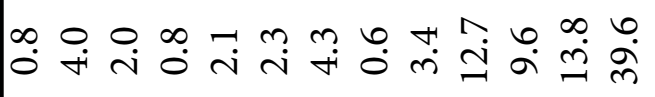 & 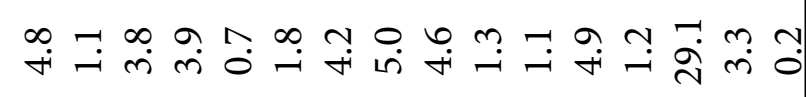 \\
\hline 8 言 & 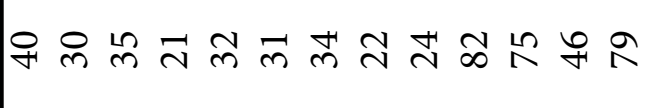 & 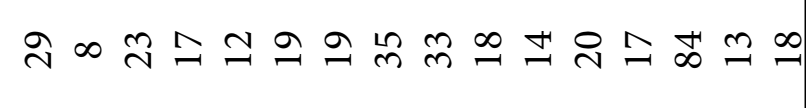 \\
\hline 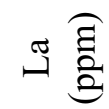 & 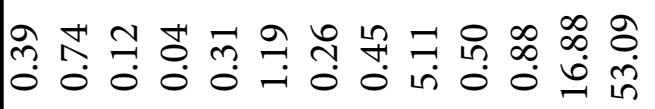 & 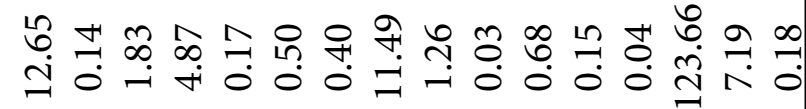 \\
\hline$>\widehat{\overline{0}}$ & 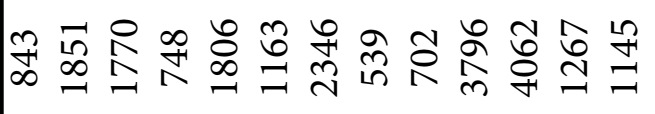 & 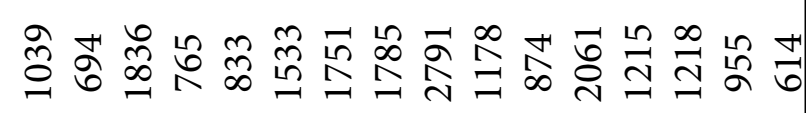 \\
\hline $\begin{array}{l}0 \\
\bar{\Xi} \\
0 \\
\text { के }\end{array}$ & 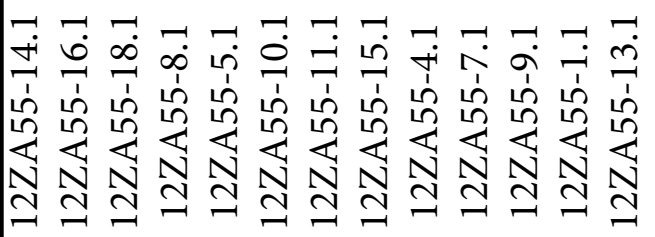 & 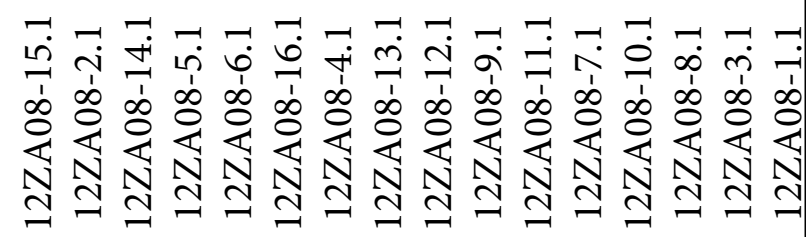 \\
\hline
\end{tabular}




\begin{tabular}{|c|c|c|}
\hline & 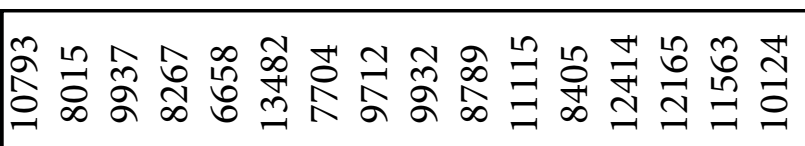 & 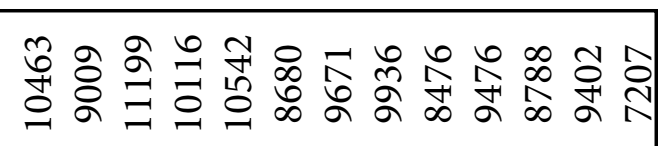 \\
\hline$\Xi$ ప్ & 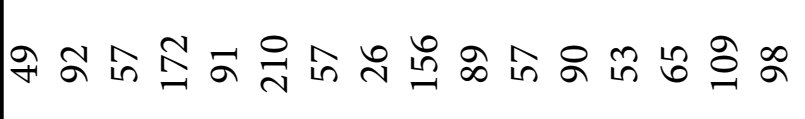 & $\stackrel{\infty}{\sim}$ 삭 웡 \\
\hline & 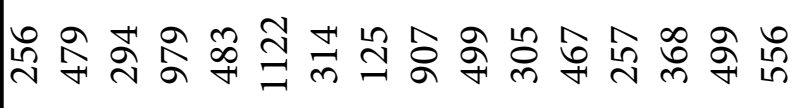 & 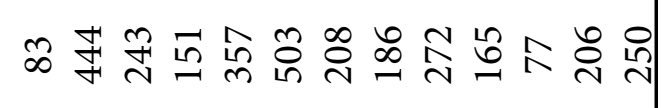 \\
\hline 已 高 & F 서척 & 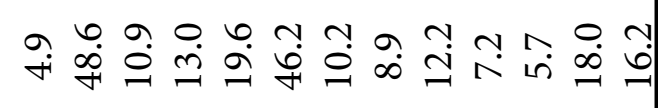 \\
\hline & 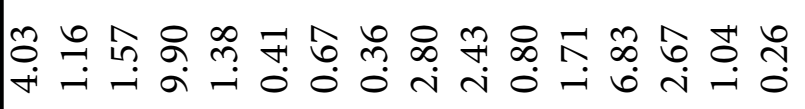 & 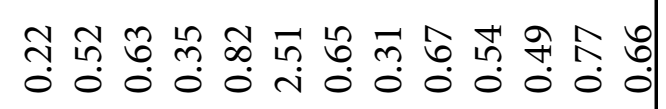 \\
\hline & 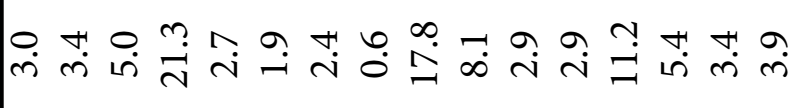 & 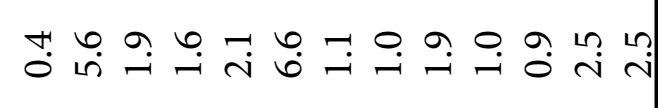 \\
\hline 吾言 & 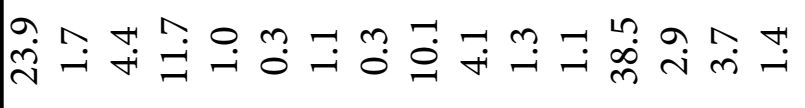 & 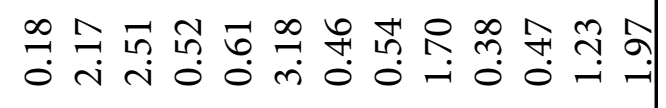 \\
\hline 8 言 & 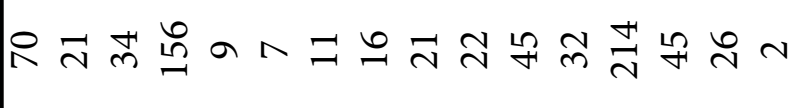 & 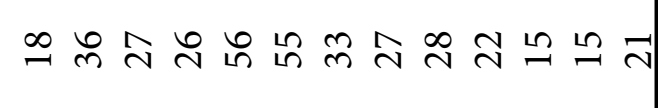 \\
\hline ⿶凵 & 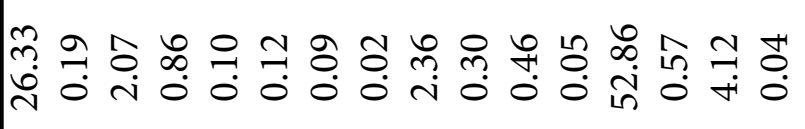 & 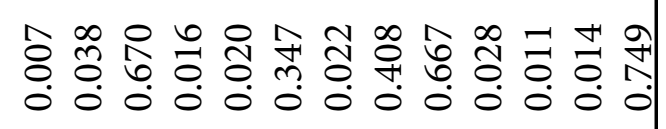 \\
\hline$>\widehat{\bar{\Xi}}$ & 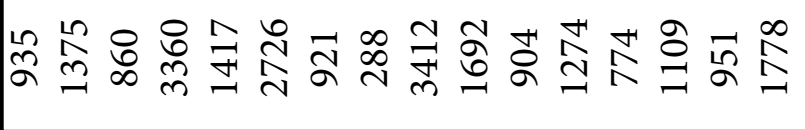 & 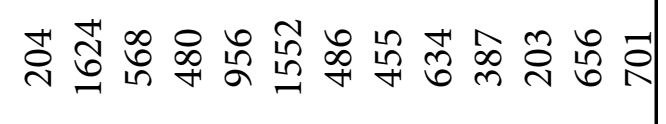 \\
\hline 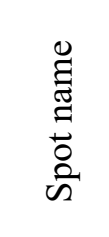 & 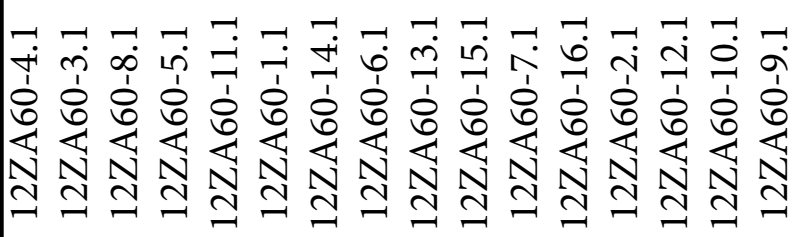 & 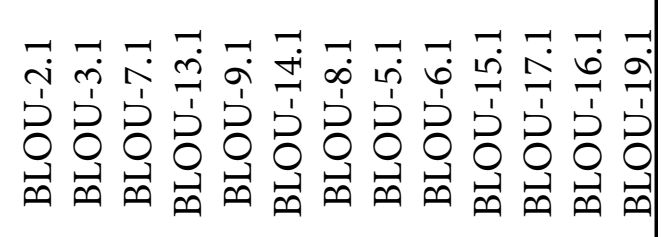 \\
\hline
\end{tabular}




\begin{tabular}{|c|c|c|c|}
\hline 纴 言 & 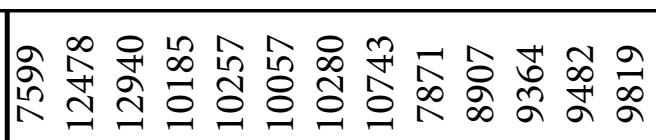 & 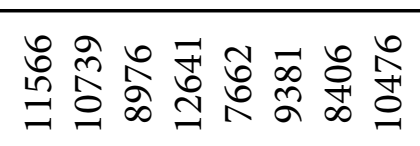 & 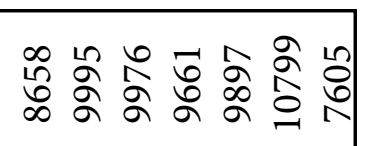 \\
\hline & 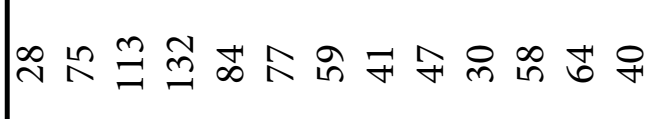 & 占舫 & 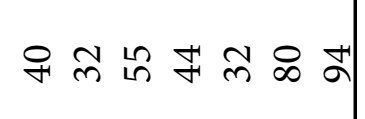 \\
\hline 리 흠 & 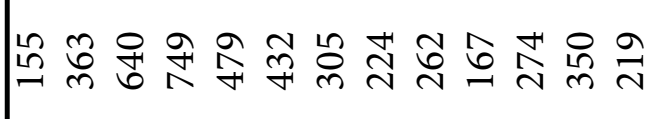 & 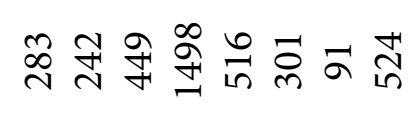 & 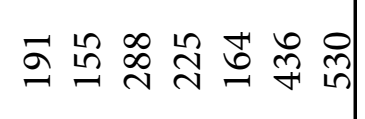 \\
\hline & 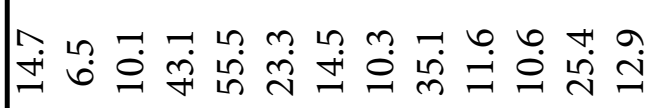 & 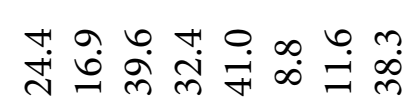 & 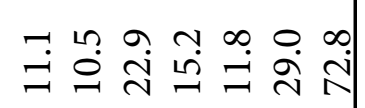 \\
\hline & 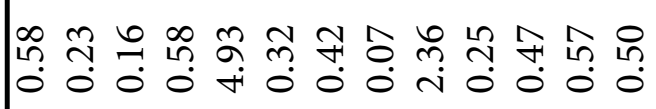 & 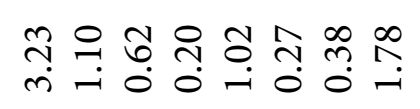 & 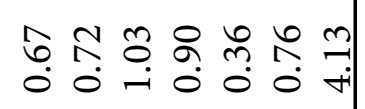 \\
\hline 在 & 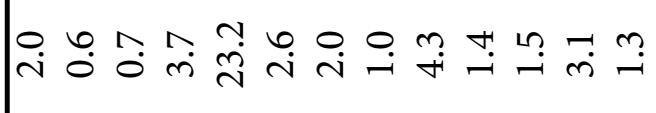 & 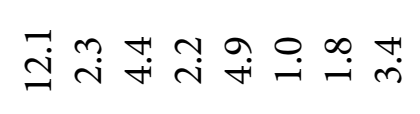 & 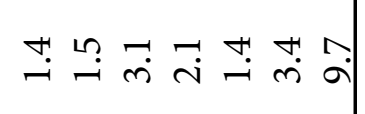 \\
\hline 吾言 & 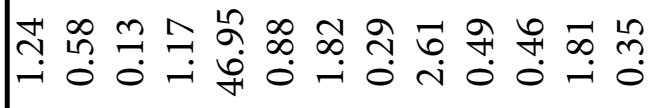 & 品 국 & 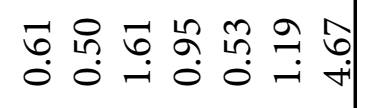 \\
\hline 8 言 & 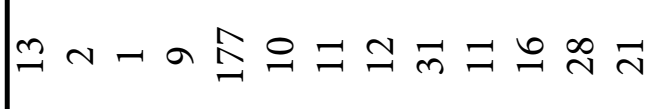 & 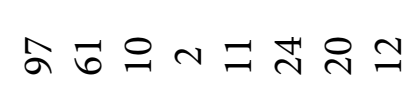 & 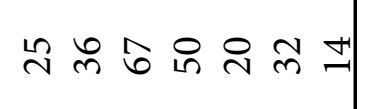 \\
\hline ฐ & 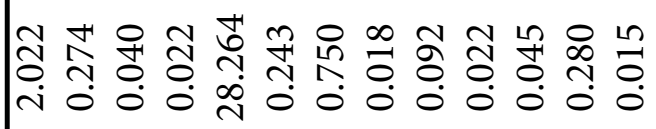 & 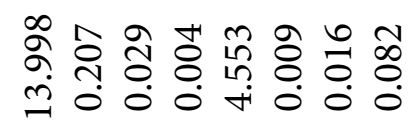 & 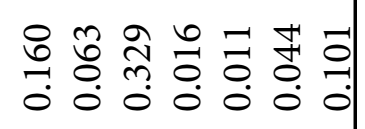 \\
\hline$>\widehat{\overline{⿳ 亠 口 冋}}$ & 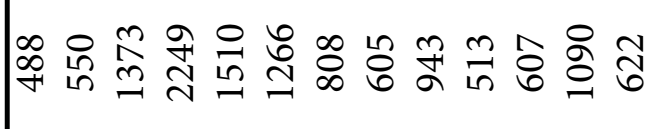 & مे: & 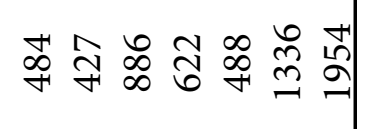 \\
\hline 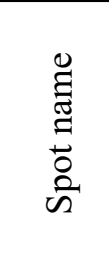 & 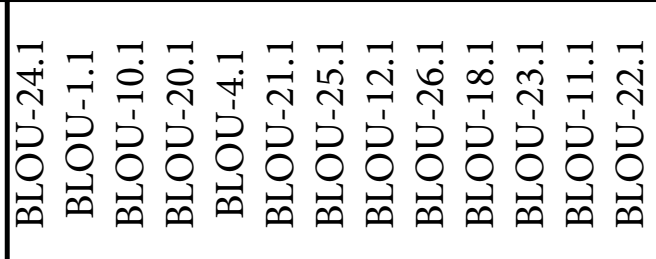 & 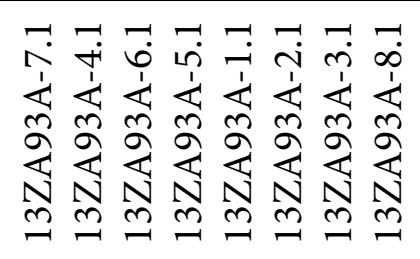 & 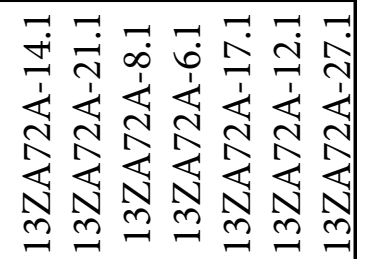 \\
\hline
\end{tabular}




\begin{tabular}{|c|c|c|}
\hline & 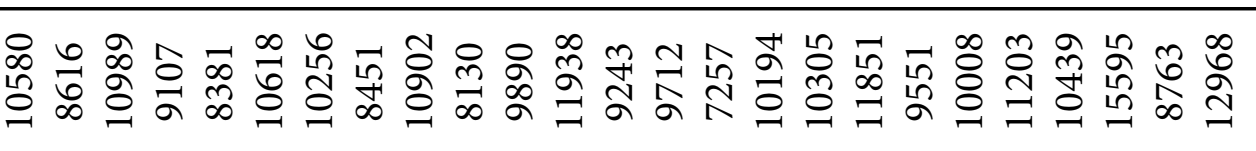 & 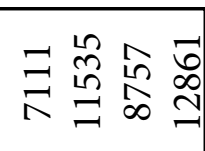 \\
\hline & 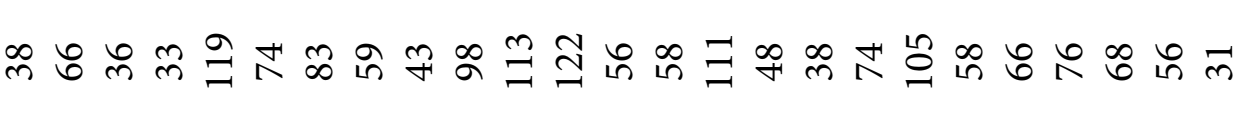 & $\widehat{\exists} \triangleq$ \\
\hline & 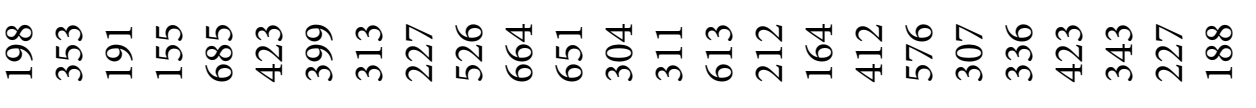 & $\frac{2}{1}$ \\
\hline & 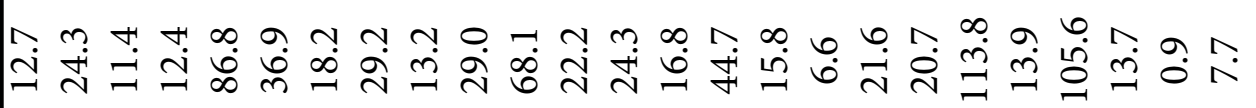 & 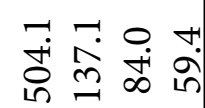 \\
\hline 函言 & 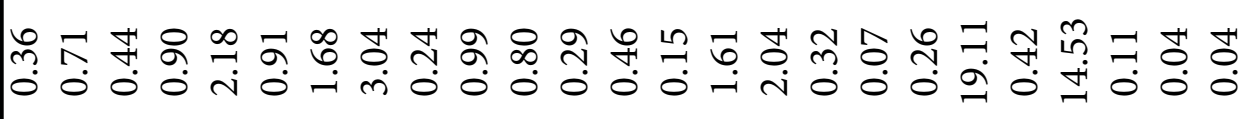 & 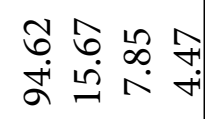 \\
\hline 居 & 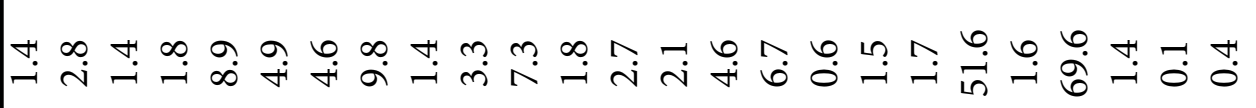 & 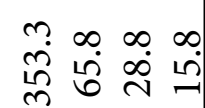 \\
\hline 艺言 & 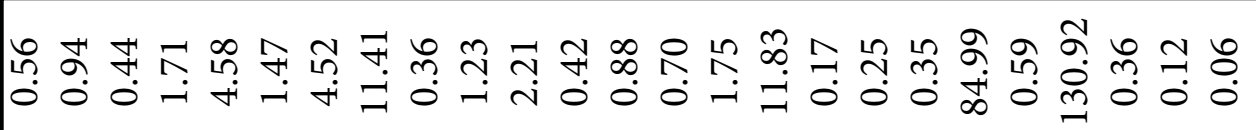 & 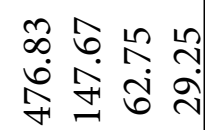 \\
\hline $8 \widehat{\bar{E}}$ & 办へ方 F \& & 峞学尽 \\
\hline 承 & 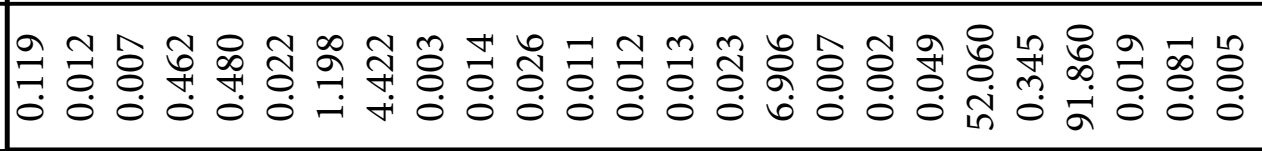 & 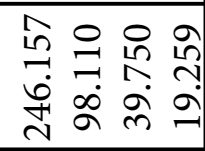 \\
\hline$>\widehat{\bar{z}}$ & 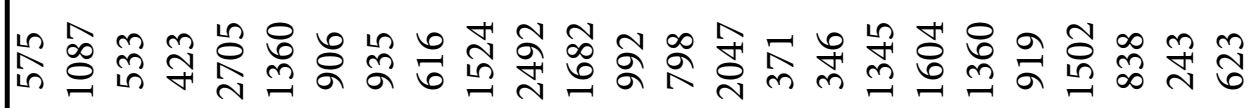 & 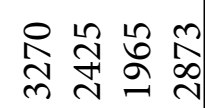 \\
\hline 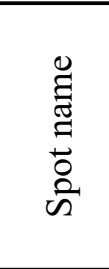 & 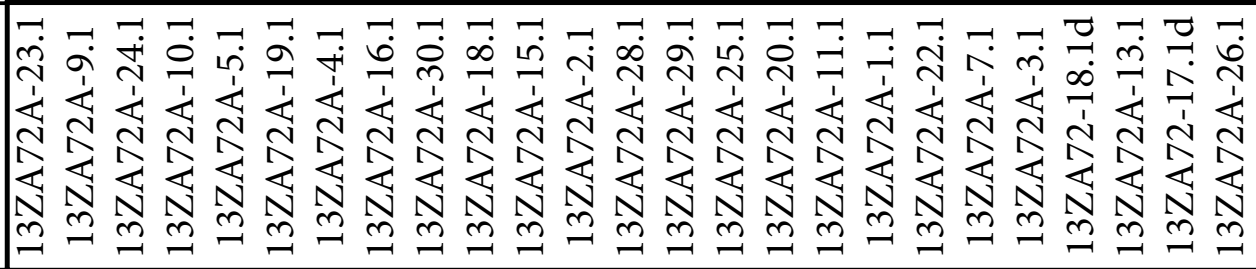 & 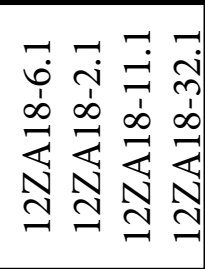 \\
\hline
\end{tabular}




\begin{tabular}{|c|c|}
\hline$\Phi$ 就 & 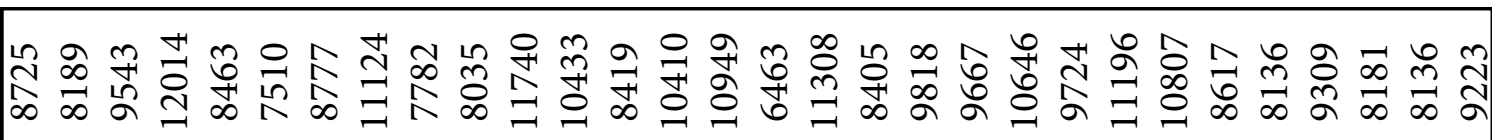 \\
\hline$\Xi$ 言 & 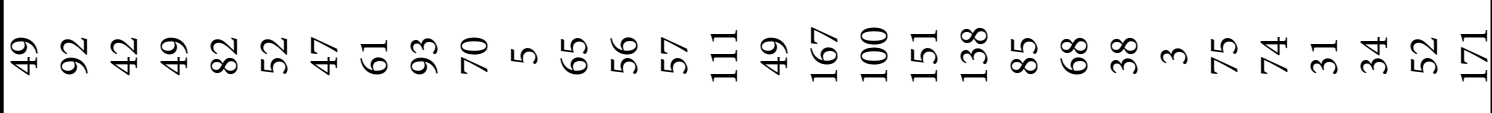 \\
\hline Е & 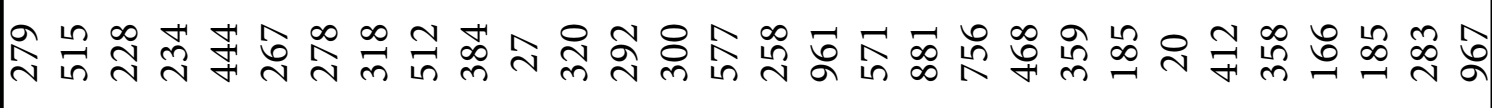 \\
\hline & 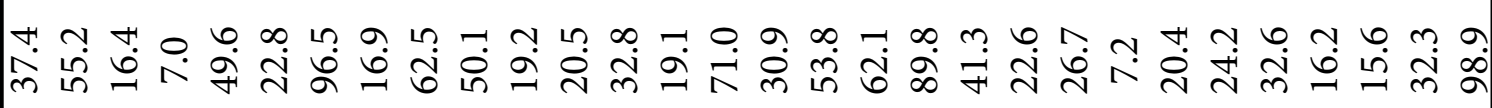 \\
\hline & 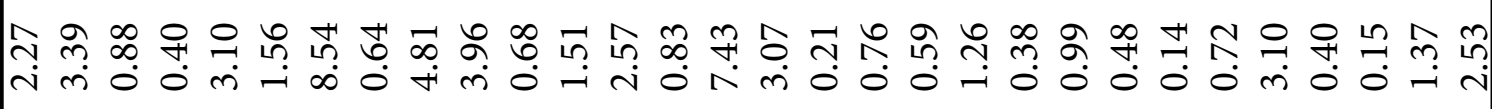 \\
\hline ह $\overline{\bar{n}}$ & 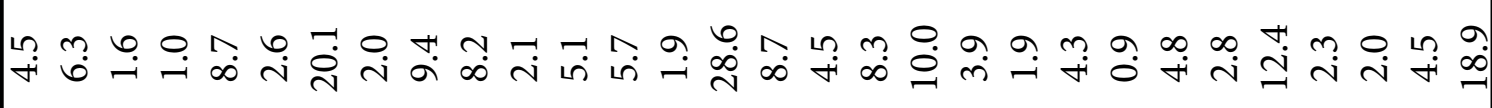 \\
\hline ž 产 & 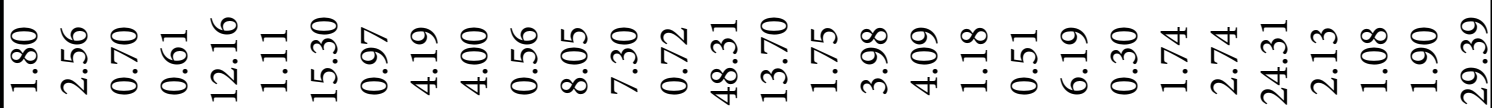 \\
\hline ن 言 & तิ \\
\hline$\Xi \widehat{~}$ & 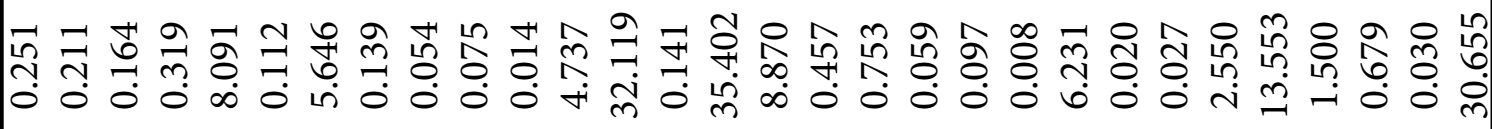 \\
\hline$\succ \widehat{\bar{~}}$ & 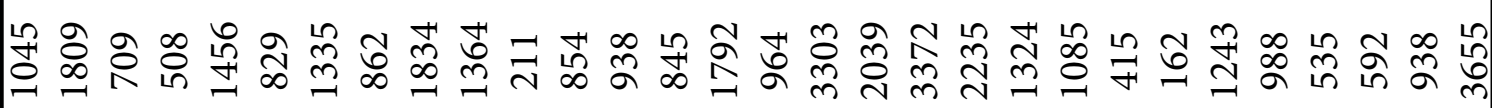 \\
\hline 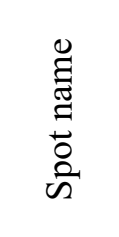 & 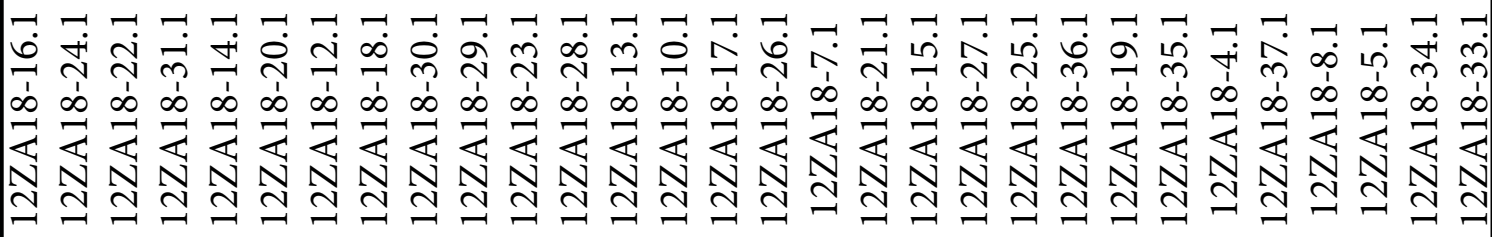 \\
\hline
\end{tabular}




\begin{tabular}{|c|c|c|}
\hline 在 흥 & 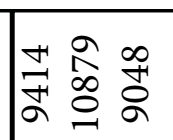 & 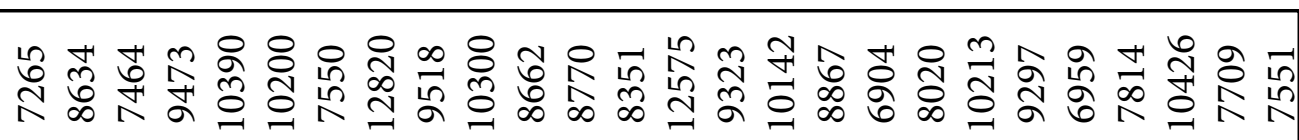 \\
\hline క & 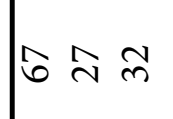 & 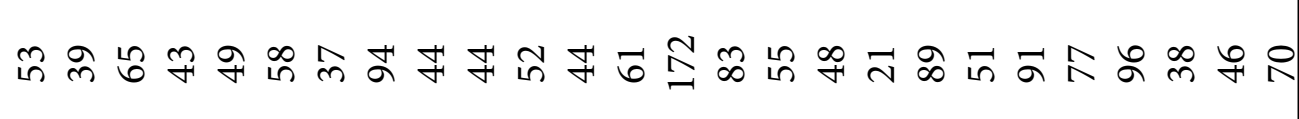 \\
\hline 不言 & 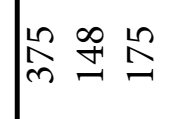 & 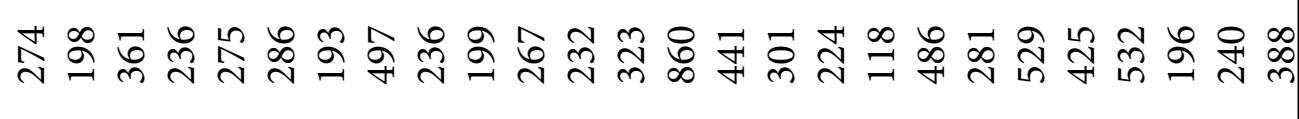 \\
\hline & 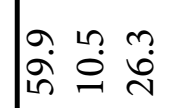 & 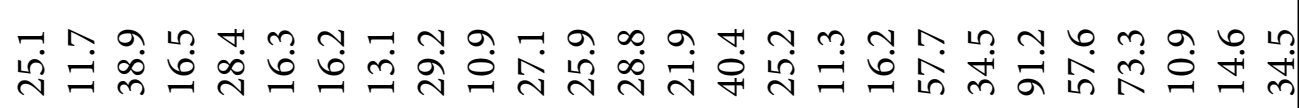 \\
\hline & 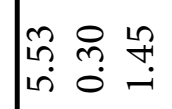 & 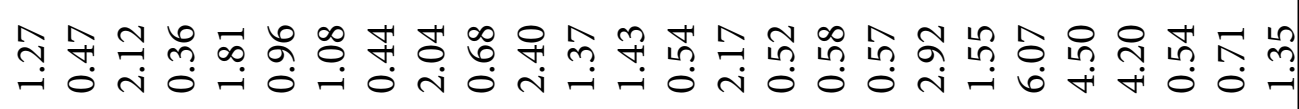 \\
\hline & 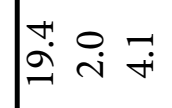 & 艿 苟 \\
\hline 台言 & 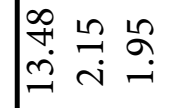 & 员 \\
\hline 8 言 & $\hat{\sim} \stackrel{\infty}{\sim}$ & 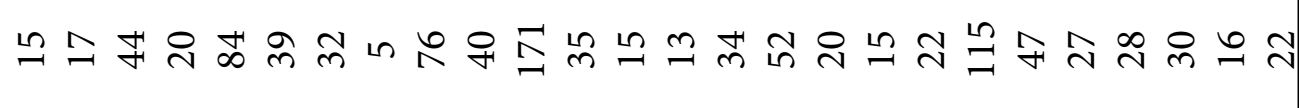 \\
\hline 承 & 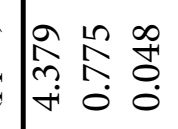 & 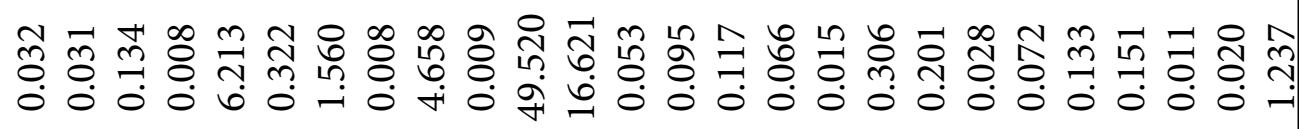 \\
\hline$>\widehat{\bar{g}}$ & :ึ̃ & 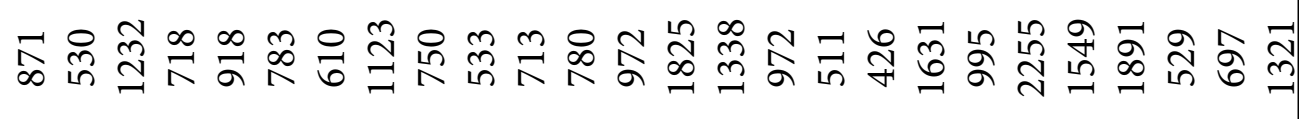 \\
\hline 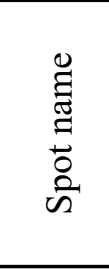 & 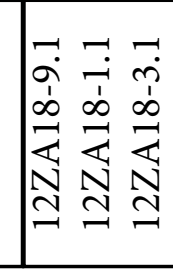 & 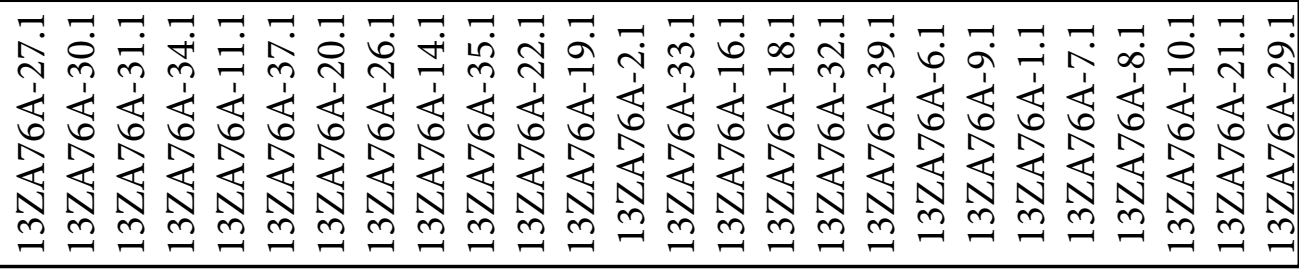 \\
\hline
\end{tabular}




\begin{tabular}{|c|c|}
\hline 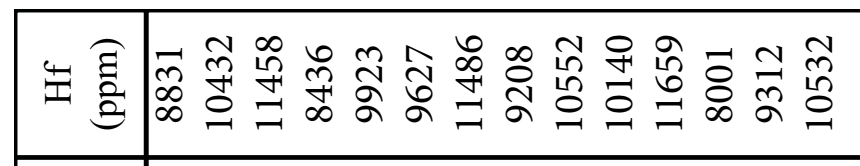 & 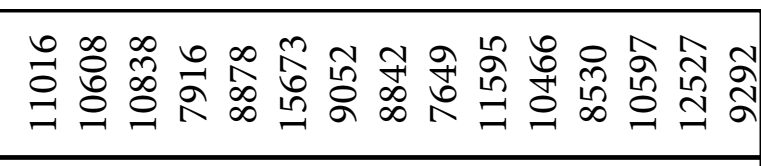 \\
\hline 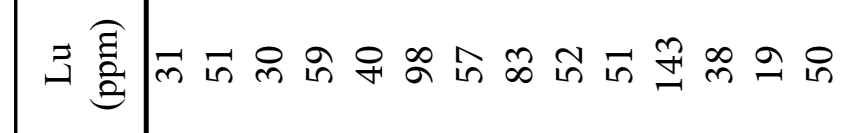 & 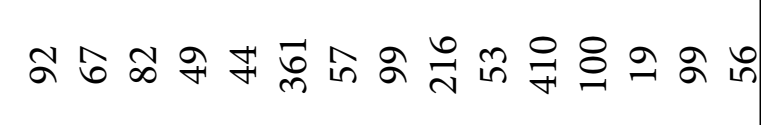 \\
\hline 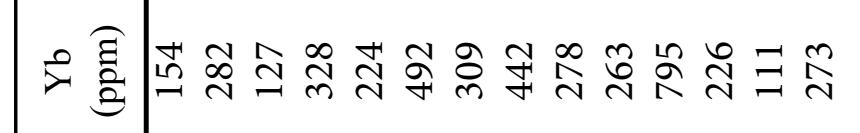 & 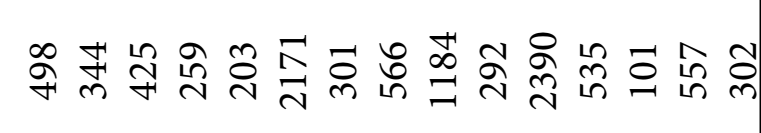 \\
\hline 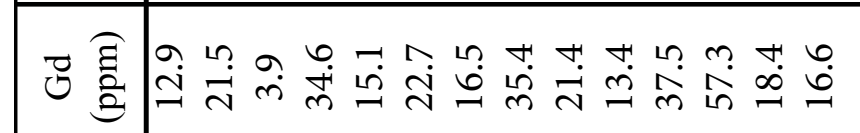 & 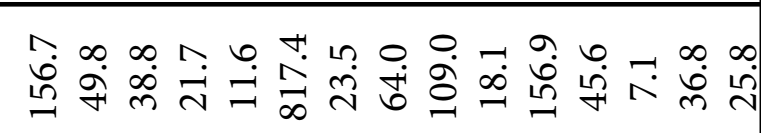 \\
\hline 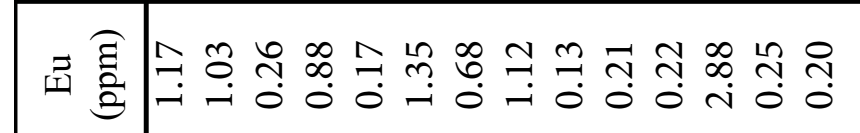 & 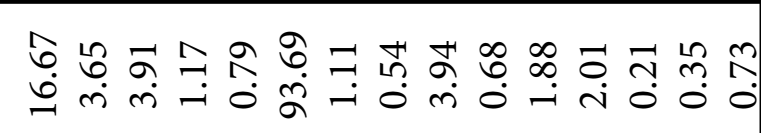 \\
\hline$=$ & 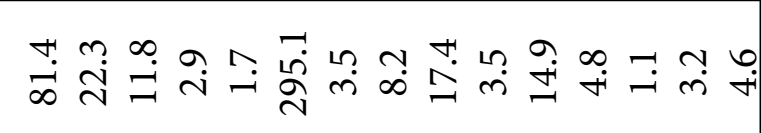 \\
\hline 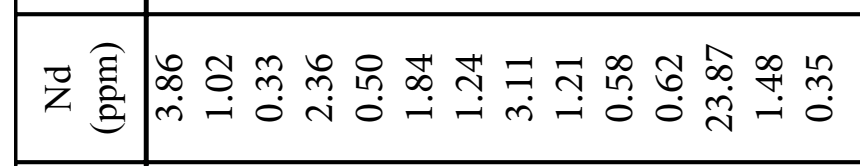 & 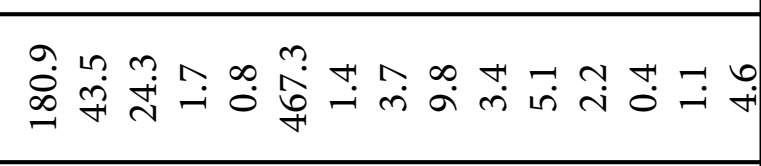 \\
\hline 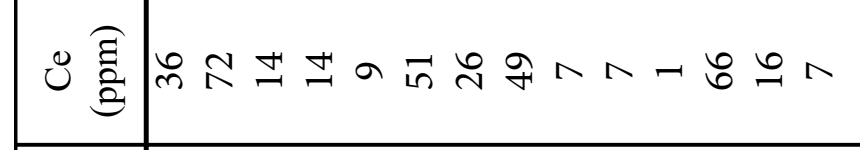 & 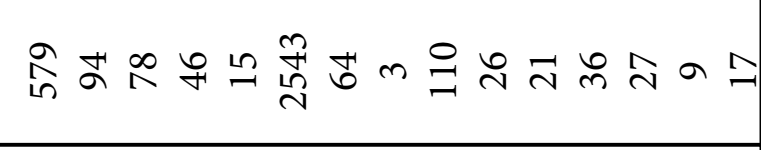 \\
\hline 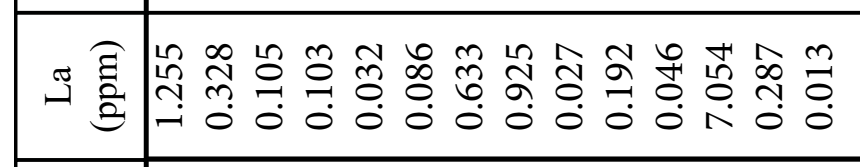 & 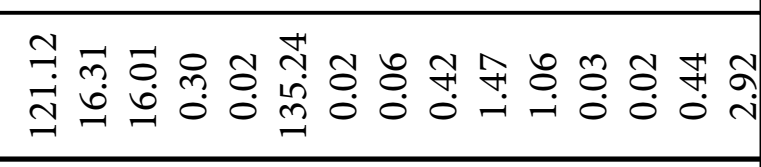 \\
\hline 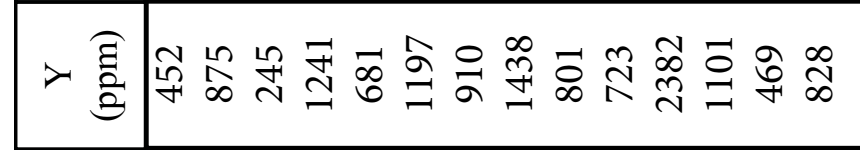 & 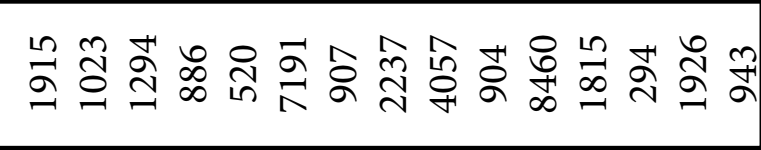 \\
\hline 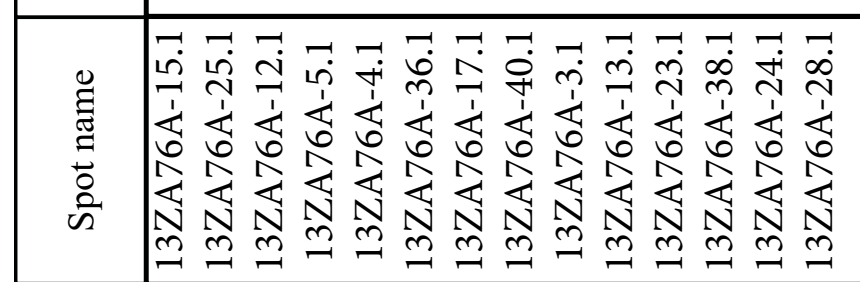 & 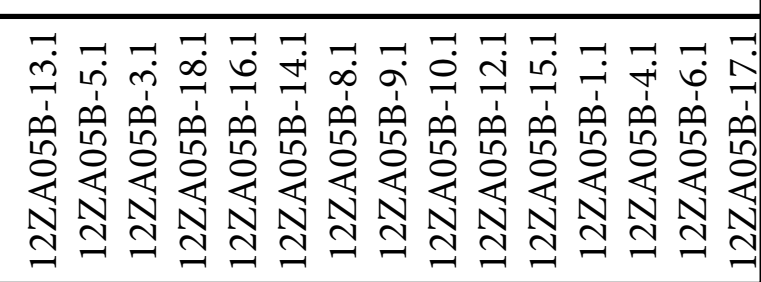 \\
\hline
\end{tabular}




\begin{tabular}{|c|c|c|}
\hline 幽言 & 吾落 & 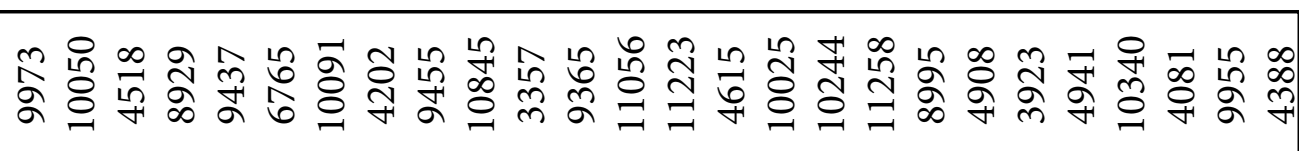 \\
\hline$\exists$ 言 & $m \cong$ & 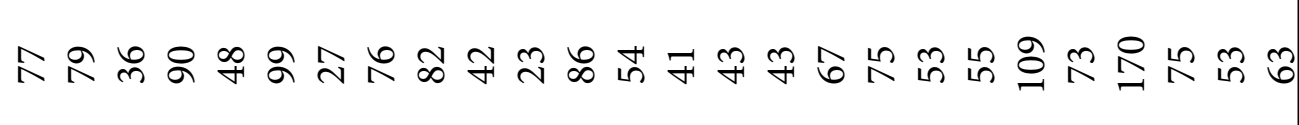 \\
\hline & 좃유 & 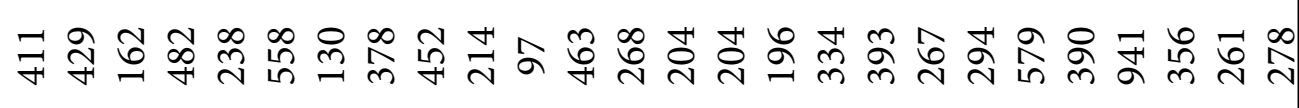 \\
\hline$\Xi$ & 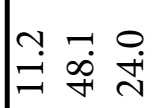 & 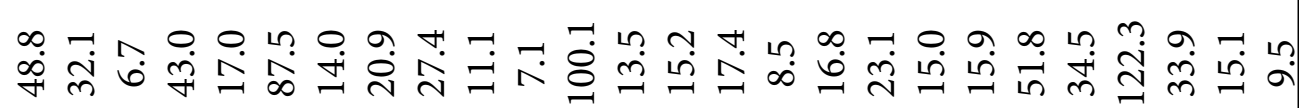 \\
\hline 㖤 & 象 & 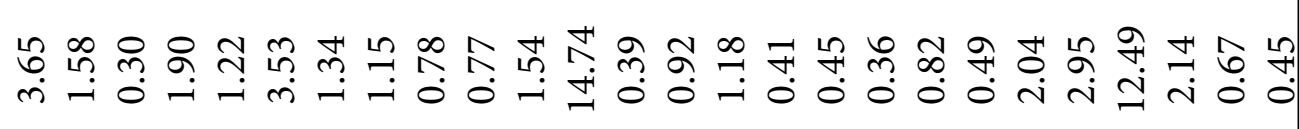 \\
\hline 局 & 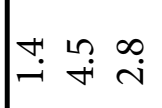 & 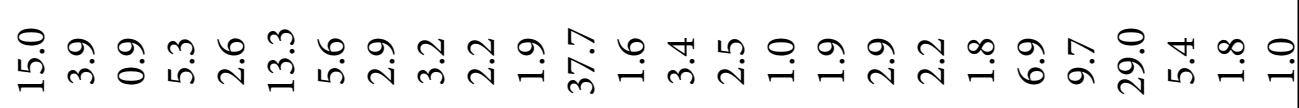 \\
\hline z $\overline{\bar{a}}$ & 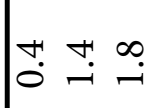 & 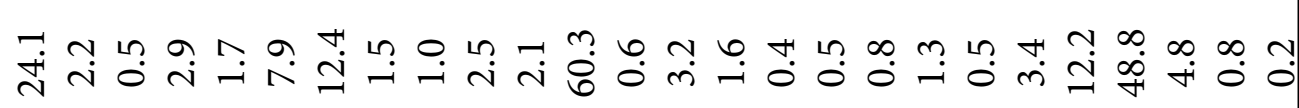 \\
\hline 8 言 & $\infty 69$ & 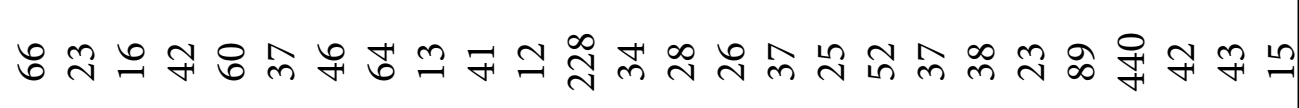 \\
\hline 言言 & $\begin{array}{lll}0 & 0 \\
0 & 0 & 0 \\
0 & 0 & 0\end{array}$ & 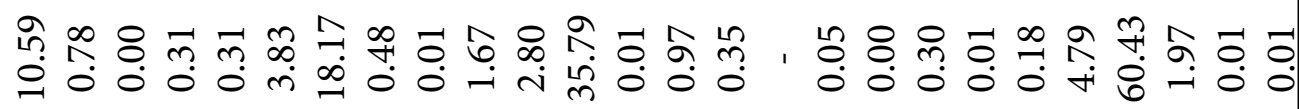 \\
\hline$\succ \widehat{\bar{~}}$ & 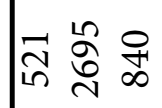 & 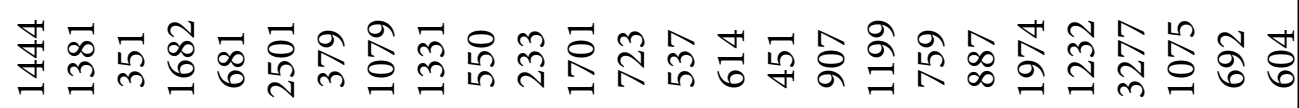 \\
\hline 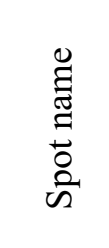 & 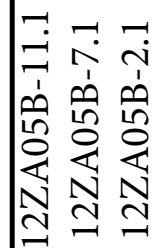 & 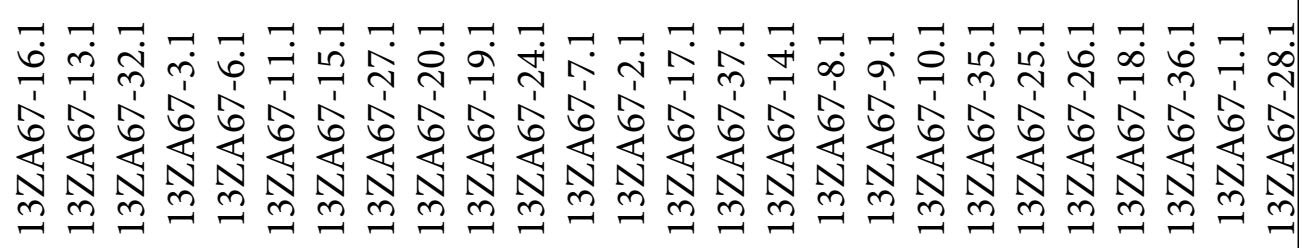 \\
\hline
\end{tabular}




\begin{tabular}{|c|c|c|}
\hline 生言 & 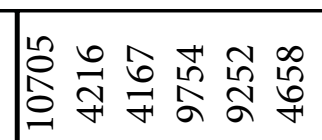 & 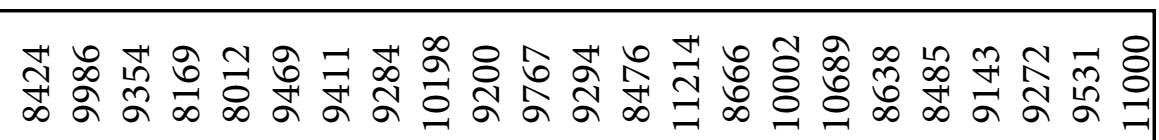 \\
\hline$\Xi$ 言 & 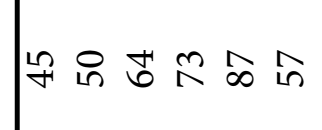 & 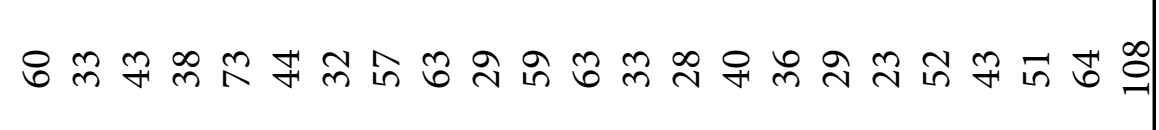 \\
\hline & 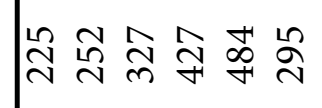 & 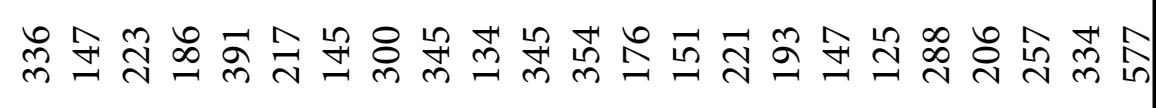 \\
\hline & 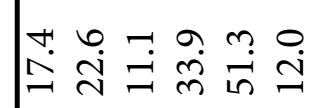 & 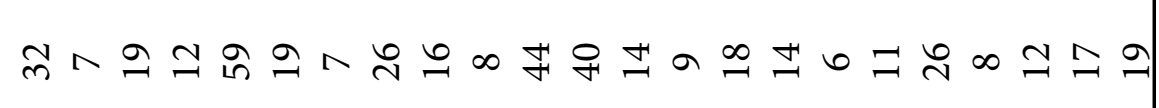 \\
\hline & 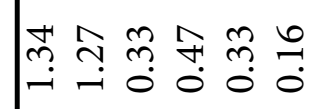 & 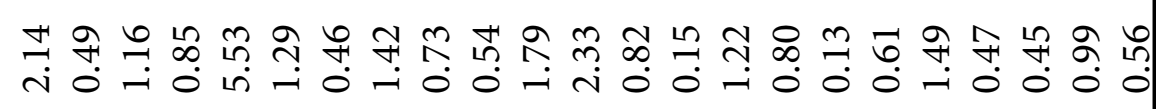 \\
\hline & Pُ & 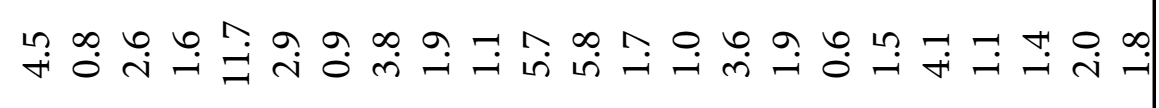 \\
\hline & 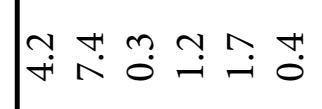 & 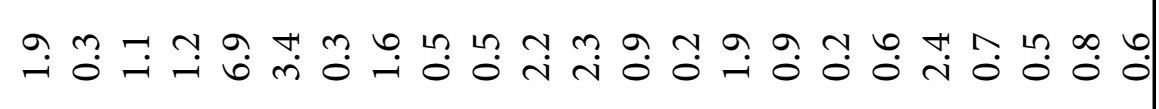 \\
\hline ن 言 & in $\stackrel{\infty}{\infty} \wedge n g$ & 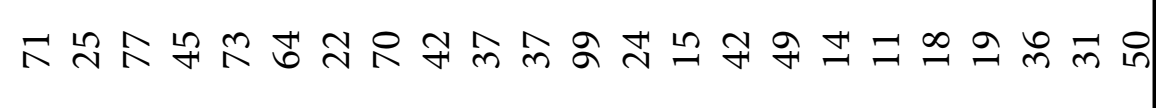 \\
\hline Ð & 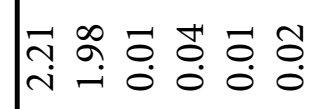 & 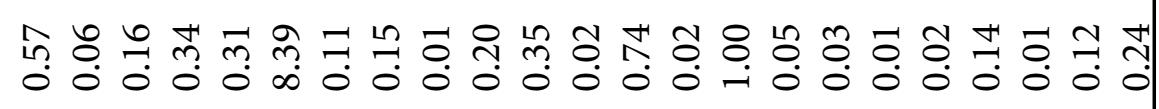 \\
\hline$\succ \widehat{\bar{z}}$ & 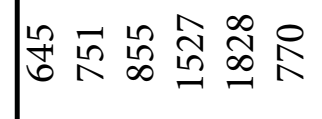 & 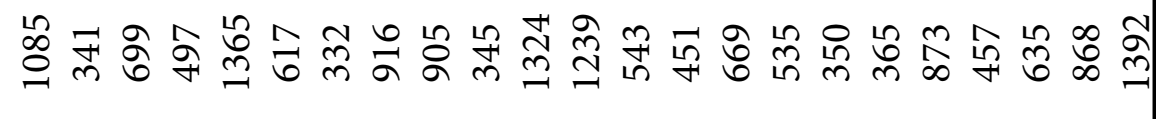 \\
\hline 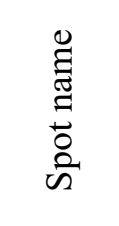 & 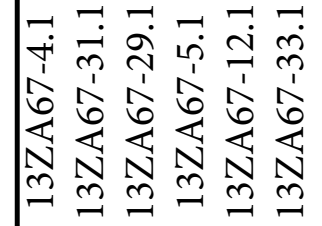 & 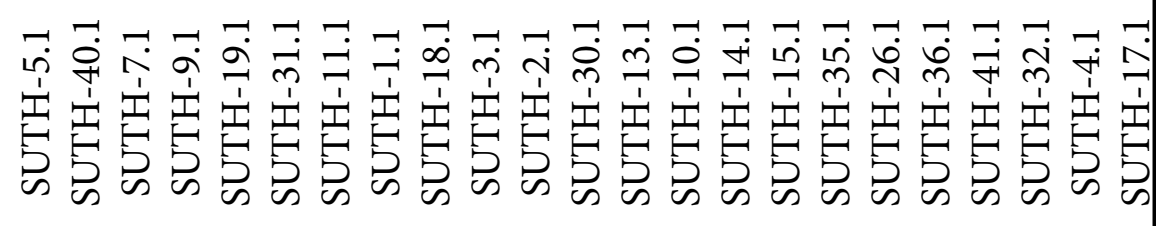 \\
\hline
\end{tabular}




\begin{tabular}{|c|c|c|c|}
\hline 壻 & 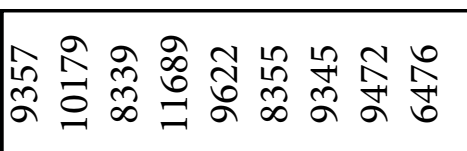 & 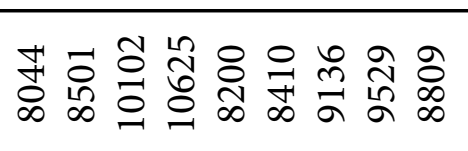 & 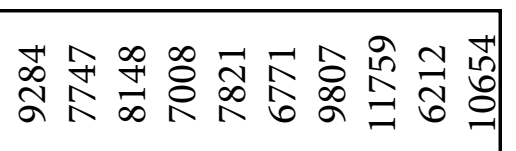 \\
\hline ت & $\hat{\alpha}=\vec{\exists}=\infty i$ & 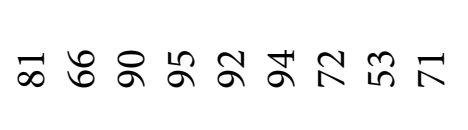 & 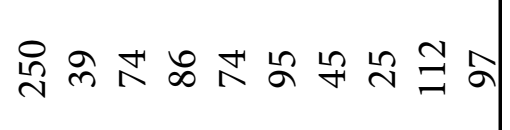 \\
\hline 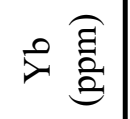 & 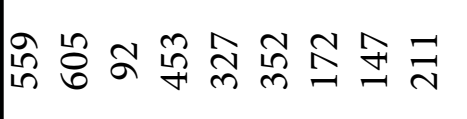 & 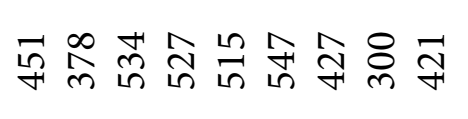 & 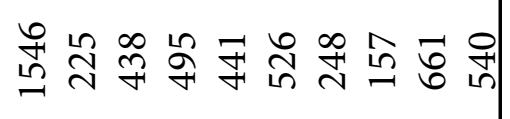 \\
\hline تृ & 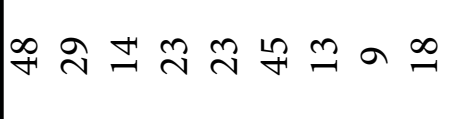 & 方 & ofo \\
\hline 㓙言 & 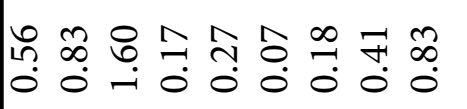 & 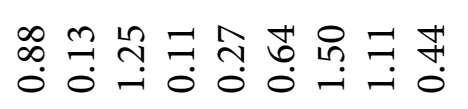 & 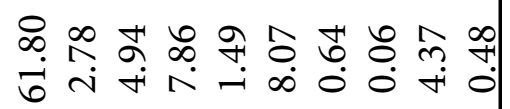 \\
\hline 豆言 & 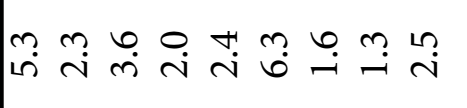 & 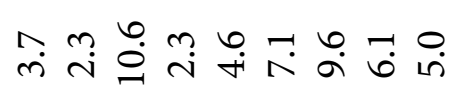 & 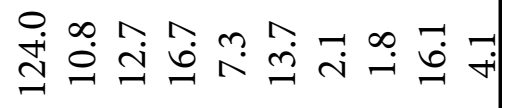 \\
\hline च & 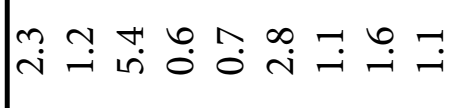 & 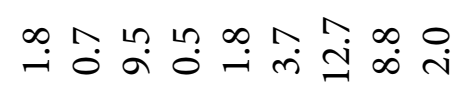 & 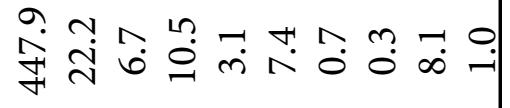 \\
\hline 8 言 & $\pi \approx i n \wedge m \simeq 9 \pi$ \& & 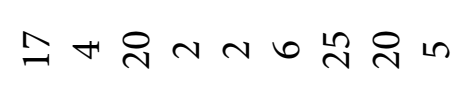 & 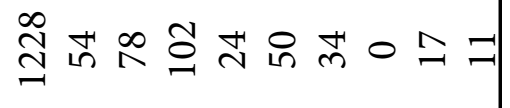 \\
\hline 茎言 & 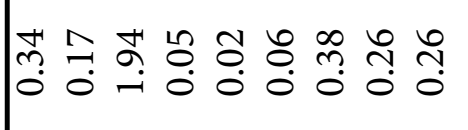 & 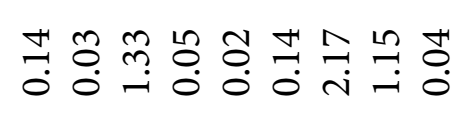 & 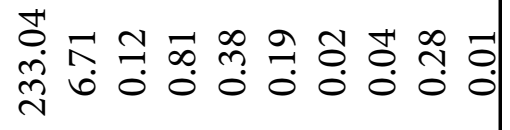 \\
\hline$>$ 言 & 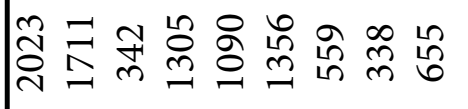 & 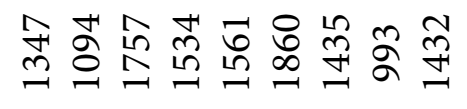 & 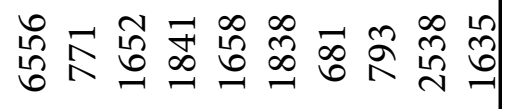 \\
\hline 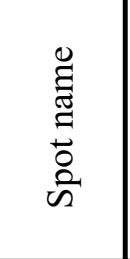 & 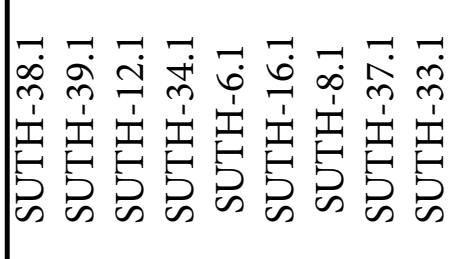 & 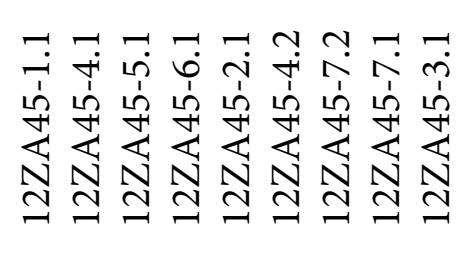 & 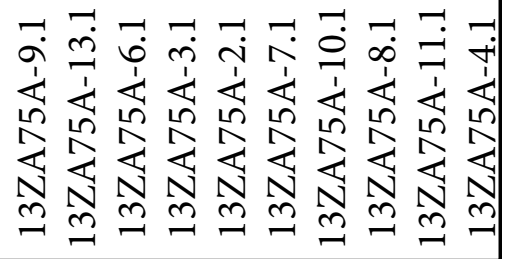 \\
\hline
\end{tabular}




\begin{tabular}{|c|c|}
\hline 出 芯 & 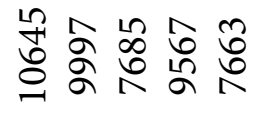 \\
\hline ت & 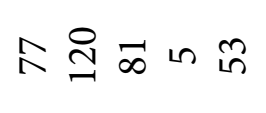 \\
\hline 규류 & 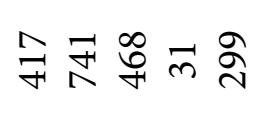 \\
\hline రृ & 约螨 \\
\hline 可 & 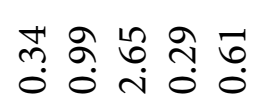 \\
\hline ๘ & 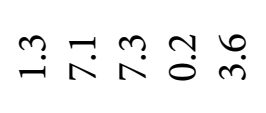 \\
\hline Z & 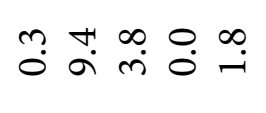 \\
\hline ن & $\stackrel{n}{n}$ 우늠 $\rightarrow$ \\
\hline 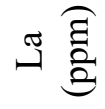 & 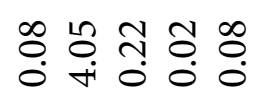 \\
\hline$>\widehat{\overparen{\Xi}}$ & 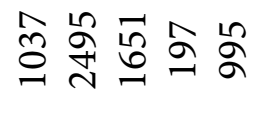 \\
\hline 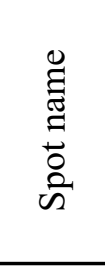 & 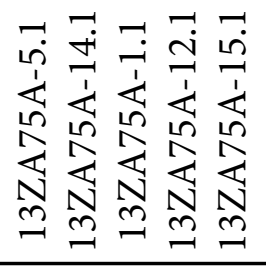 \\
\hline
\end{tabular}


Appendix E: SHRIMP Ti-in-zircon temperature analyses

\begin{tabular}{|c|c|c|c|c|}
\hline Spot name & $\begin{array}{c}{ }^{48} \mathrm{Ti} \\
(\mathrm{ppm})\end{array}$ & ${ }^{48} \mathrm{Ti} /{ }^{49} \mathrm{Ti}$ & $\begin{array}{c}\mathrm{Fe} \\
(\mathrm{ppm})\end{array}$ & $\underset{{ }^{\circ} \mathrm{C}}{\text { Temp }\left({ }^{48} \mathrm{Ti}\right)}$ \\
\hline $12 \mathrm{ZA} 23-13.1$ & 12.3 & 13.5 & 28.3 & 758 \\
\hline 12ZA23-12.1 & 27.7 & 13.8 & 339.8 & 843 \\
\hline 12ZA23-5.1 & 22.8 & 13.3 & 79.5 & 821 \\
\hline 12ZA23-9.1 & 8.1 & 13.3 & 0.3 & 719 \\
\hline 12ZA23-1.1 & 13.1 & 13.3 & 0.1 & 764 \\
\hline 12ZA23-7.1 & 9.1 & 13.4 & 4.2 & 729 \\
\hline 12ZA23-11.1 & 3.9 & 13.1 & 2.1 & 657 \\
\hline 12ZA23-4.1 & 10.2 & 13.6 & 1.1 & 741 \\
\hline 12ZA23-16.1 & 3.6 & 14.5 & 1.7 & 652 \\
\hline 12ZA23-6.1 & 8.2 & 13.8 & 2.4 & 721 \\
\hline 12ZA23-8.1 & 14.9 & 13.5 & 7.7 & 777 \\
\hline 12ZA23-14.1 & 11.7 & 13.3 & 4.4 & 753 \\
\hline 12ZA23-3.1 & 5.8 & 13.3 & 0.6 & 691 \\
\hline 12ZA23-10.1 & 7.9 & 13.6 & 21.1 & 717 \\
\hline 12ZA23-2.1 & 9.8 & 13.2 & 1.6 & 736 \\
\hline 12ZA23-15.1 & 15.6 & 13.9 & 0.3 & 781 \\
\hline 12ZA54-7.1 & 12.4 & 13.5 & 1109.4 & 759 \\
\hline 12ZA54-5.1 & 13.5 & 13.3 & 38.3 & 767 \\
\hline 12ZA54-12.1 & 22.1 & 12.7 & 34.1 & 818 \\
\hline 12ZA54-6.1 & 12.9 & 13.8 & 17.1 & 763 \\
\hline 12ZA54-14.1 & 13.0 & 12.9 & 3.7 & 764 \\
\hline 12ZA54-8.1 & 7.1 & 14.9 & 9.1 & 708 \\
\hline 12ZA54-11.1 & 14.7 & 13.3 & 0.1 & 776 \\
\hline 12ZA54-15.1 & 18.6 & 13.3 & 1.2 & 800 \\
\hline 12ZA54-16.1 & 20.4 & 13.1 & 2.3 & 809 \\
\hline 12ZA54-9.1 & 15.0 & 13.5 & 3.7 & 778 \\
\hline 12ZA54-4.1 & 14.9 & 13.2 & 0.4 & 777 \\
\hline 12ZA54-1.1 & 11.4 & 13.0 & 0.1 & 751 \\
\hline 12ZA54-13.1 & 18.8 & 13.0 & 0.0 & 801 \\
\hline 12ZA54-3.1 & 8.5 & 13.1 & 105.4 & 724 \\
\hline 12ZA54-10.1 & 5.7 & 13.5 & 4.7 & 689 \\
\hline 12ZA54-2.1 & 13.5 & 14.3 & 31.0 & 768 \\
\hline 12ZA61-7.1 & 9.4 & 13.1 & 250.0 & 741 \\
\hline 12ZA61-9.1 & 16.2 & 13.1 & 228.5 & 794 \\
\hline 12ZA61-14.1 & 9.2 & 12.9 & 107.8 & 738 \\
\hline 12ZA61-12.1 & 9.0 & 14.3 & 28.6 & 736 \\
\hline 12ZA61-10.1 & 16.9 & 13.5 & 168.6 & 798 \\
\hline 12ZA61-11.1 & 9.9 & 13.0 & 1.9 & 745 \\
\hline
\end{tabular}




\begin{tabular}{|c|c|c|c|c|}
\hline Spot name & $\begin{array}{c}{ }^{48} \mathrm{Ti} \\
(\mathrm{ppm})\end{array}$ & ${ }^{48} \mathrm{Ti} /{ }^{49} \mathrm{Ti}$ & $\begin{array}{c}\mathrm{Fe} \\
(\mathrm{ppm})\end{array}$ & ${ }_{{ }^{\circ} \mathrm{C}}^{\text {Temp }}\left({ }^{48} \mathrm{Ti}\right)$ \\
\hline 12ZA61-8.1 & 19.4 & 13.3 & 1.0 & 812 \\
\hline 12ZA61-15.1 & 7.1 & 13.5 & 12.3 & 715 \\
\hline 12ZA61-4.1 & 6.1 & 13.3 & 3.1 & 702 \\
\hline 12ZA61-1.1 & 7.9 & 12.8 & 253.1 & 724 \\
\hline 12ZA61-6.1 & 11.9 & 13.2 & 689.1 & 763 \\
\hline 12ZA61-5.1 & 12.9 & 13.9 & 0.0 & 771 \\
\hline 12ZA61-13.1 & 5.1 & 13.8 & 0.3 & 687 \\
\hline 12ZA61-2.1 & 27.3 & 13.3 & 2.1 & 850 \\
\hline 12ZA61-3.1 & 5.3 & 13.8 & 22.1 & 690 \\
\hline 12ZA07-11.1 & 44.5 & 13.6 & 3497.5 & 932 \\
\hline 12ZA07-25.1 & - & - & - & - \\
\hline 12ZA07-9.1 & 6.9 & 14.0 & 7.5 & 728 \\
\hline 12ZA07-6.1 & 11.5 & 13.1 & 2.4 & 777 \\
\hline 12ZA07-7.1 & 10.8 & 13.7 & 4.6 & 771 \\
\hline 12ZA07-8.1 & 8.3 & 13.3 & 26.8 & 746 \\
\hline 12ZA07-3.1 & 8.9 & 13.7 & 6.7 & 753 \\
\hline 12ZA07-5.1 & 9.5 & 12.7 & 0.2 & 758 \\
\hline 12ZA07-10.1 & 11.0 & 13.5 & 5.3 & 773 \\
\hline 12ZA07-4.1 & 12.2 & 13.5 & 0.3 & 783 \\
\hline 12ZA07-2.1 & 14.1 & 13.3 & 50.3 & 798 \\
\hline 12ZA07-1.1 & 34.1 & 13.2 & 28.9 & 898 \\
\hline 12ZA46-4.1 & 52.4 & 13.5 & 281.7 & 947 \\
\hline 12ZA46-10.1 & 10.4 & 12.7 & 6.7 & 762 \\
\hline 12ZA46-1.1 & 20.0 & 13.0 & 3.6 & 830 \\
\hline 12ZA46-5.1 & 10.6 & 13.5 & 0.4 & 764 \\
\hline 12ZA46-3.1 & 15.4 & 13.2 & 0.2 & 802 \\
\hline 12ZA46-7.1 & 14.0 & 13.8 & 4.3 & 792 \\
\hline 12ZA46-6.1 & 14.5 & 13.0 & 4.9 & 795 \\
\hline 12ZA46-2.1 & 8.5 & 13.2 & 12.2 & 743 \\
\hline 12ZA46-9.1 & 14.6 & 13.2 & 2.3 & 796 \\
\hline 12ZA46-8.1 & 11.6 & 13.8 & 4.2 & 773 \\
\hline 12ZA46-11.1 & 32.6 & 13.1 & 11.6 & 886 \\
\hline 12ZA22B-4.1 & 35.7 & 13.2 & 175.8 & 914 \\
\hline 12ZA22B-7.1 & 4.7 & 13.5 & 14.5 & 702 \\
\hline 12ZA22B-6.2 & 4.8 & 14.0 & 0.9 & 703 \\
\hline 12ZA22B-5.1 & 9.3 & 13.4 & 64.4 & 764 \\
\hline 12ZA22B-1.1 & 17.5 & 13.7 & 152.8 & 830 \\
\hline 12ZA22B-2.1 & 4.3 & 12.4 & 1.8 & 694 \\
\hline 12ZA22B-6.1 & 9.4 & 13.4 & 0.4 & 765 \\
\hline
\end{tabular}




\begin{tabular}{|c|c|c|c|c|}
\hline Spot name & $\begin{array}{c}{ }^{48} \mathrm{Ti} \\
(\mathrm{ppm})\end{array}$ & ${ }^{48} \mathrm{Ti} /{ }^{49} \mathrm{Ti}$ & $\begin{array}{c}\mathrm{Fe} \\
(\mathrm{ppm})\end{array}$ & $\underset{{ }^{\circ} \mathrm{C}}{\text { Temp }\left({ }^{48} \mathrm{Ti}\right)}$ \\
\hline 12ZA22B-3.1 & 7.5 & 13.4 & 34.0 & 743 \\
\hline
\end{tabular}

An electronic version of this appendix is available to improve data access. 


\begin{tabular}{|c|c|c|}
\hline \multirow{8}{*}{ 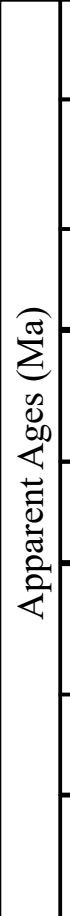 } & $+1 \sum^{\pi}$ & 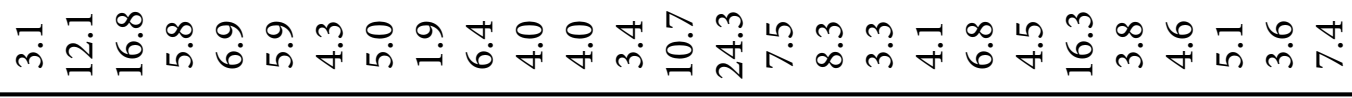 \\
\hline & 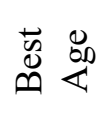 & 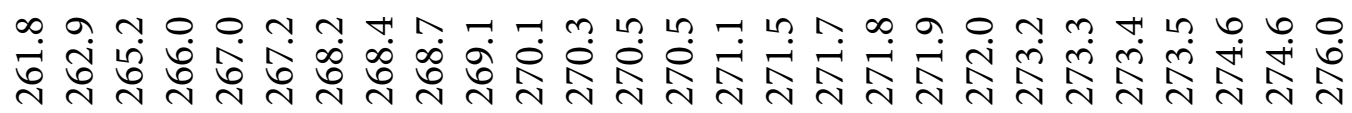 \\
\hline & $+1 \sum^{\overparen{\pi}}$ & 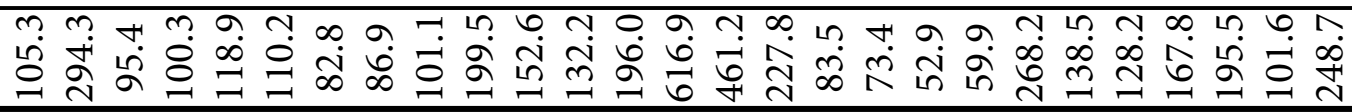 \\
\hline & के है & 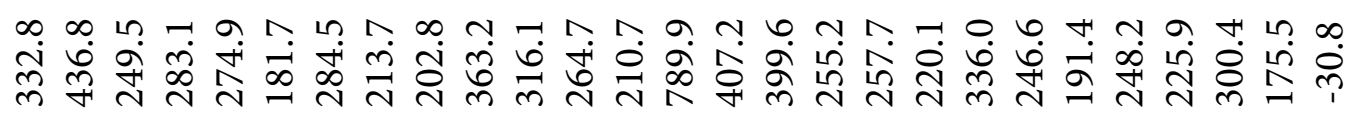 \\
\hline & 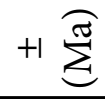 & 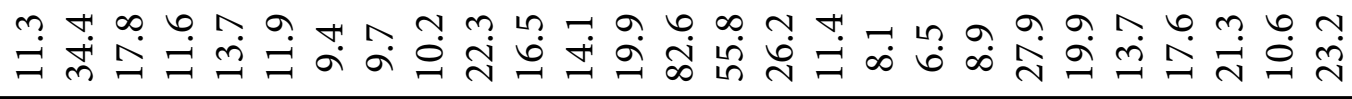 \\
\hline & 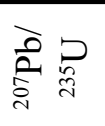 & 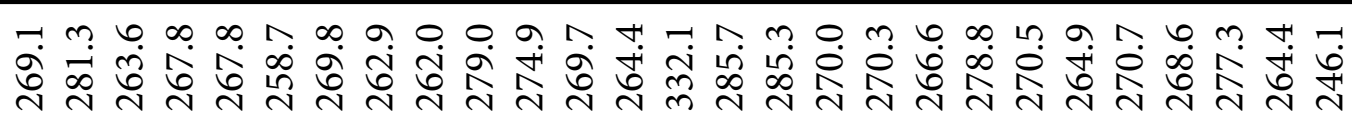 \\
\hline & $+1 \sum^{\pi}$ & 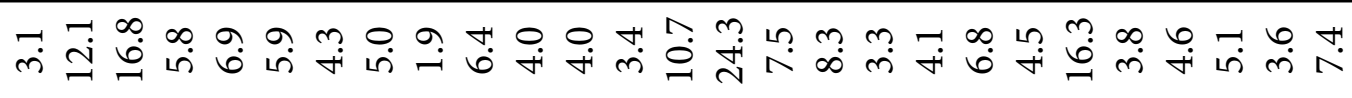 \\
\hline & 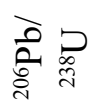 & 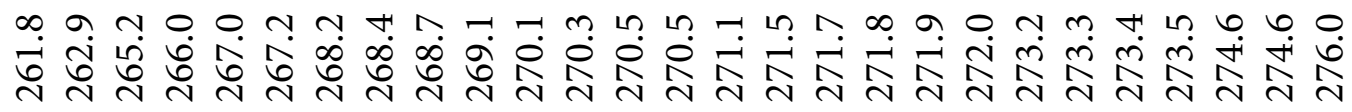 \\
\hline \multirow{7}{*}{ 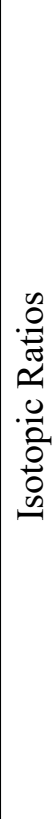 } & $\stackrel{0}{0} \stackrel{\square}{0}$ & 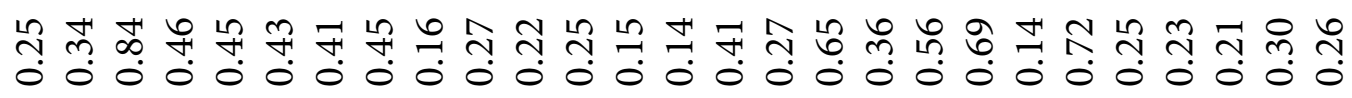 \\
\hline & $+1 \widehat{e}$ & 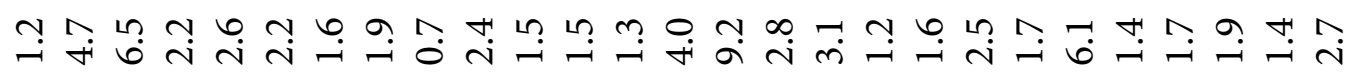 \\
\hline & 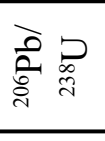 & 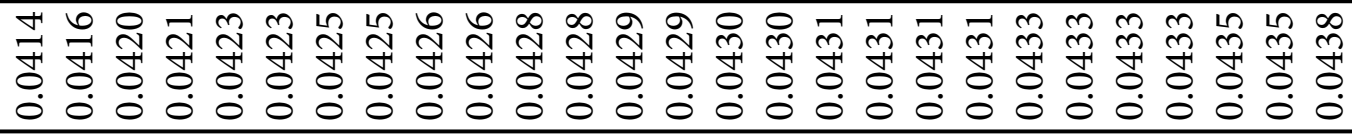 \\
\hline & $+1 \overbrace{}^{\varrho}$ & 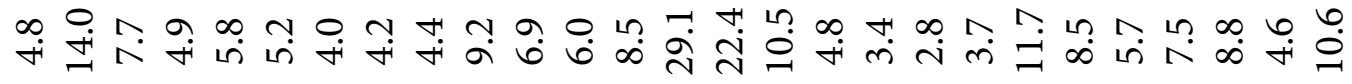 \\
\hline & 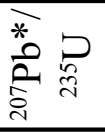 & 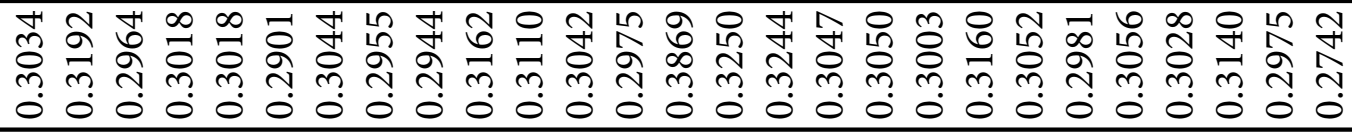 \\
\hline & 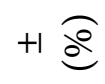 & 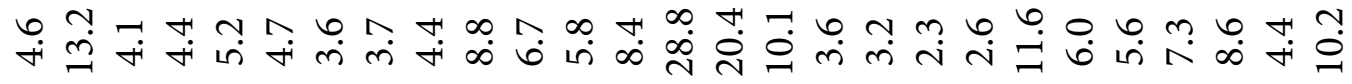 \\
\hline & 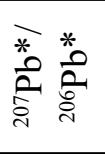 & 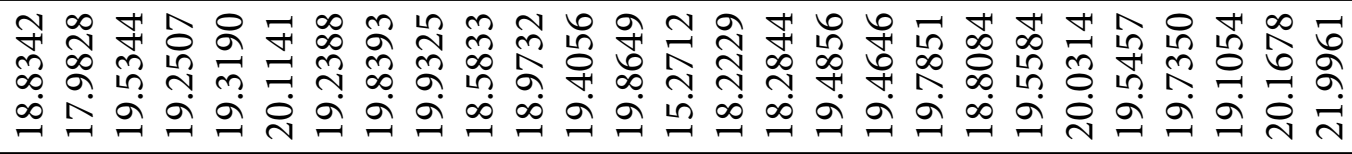 \\
\hline & $\stackrel{\Xi}{5}$ & 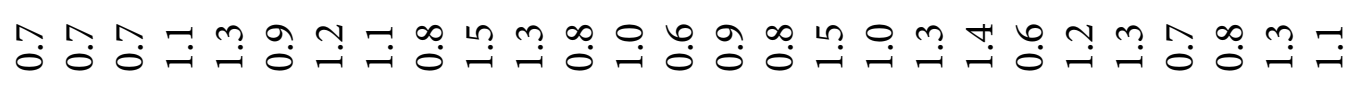 \\
\hline & $\triangleright \widehat{\overparen{\Xi}}$ & 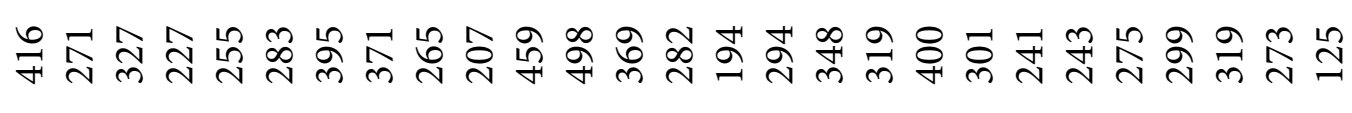 \\
\hline & 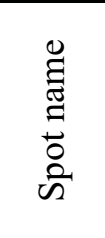 & 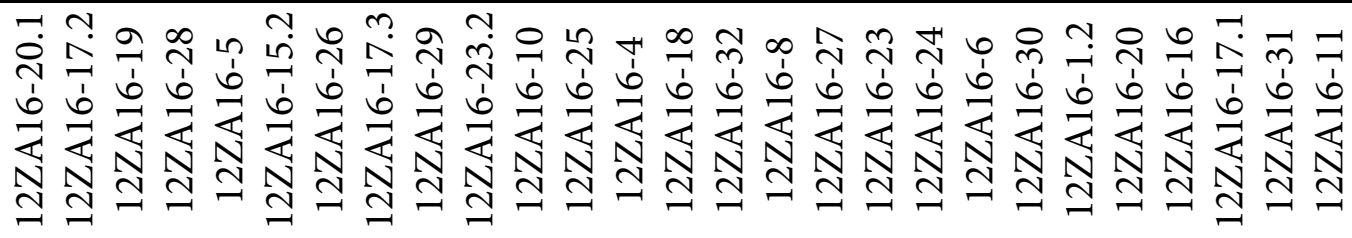 \\
\hline
\end{tabular}




\begin{tabular}{|c|c|}
\hline 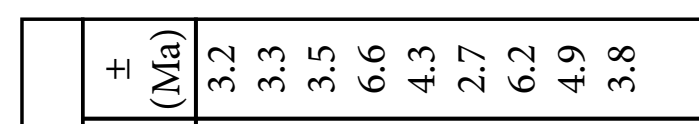 & 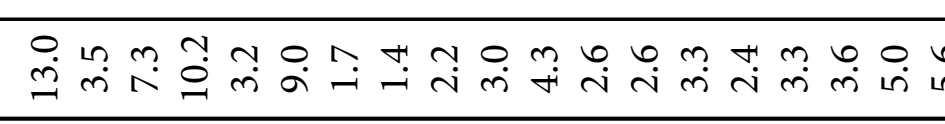 \\
\hline 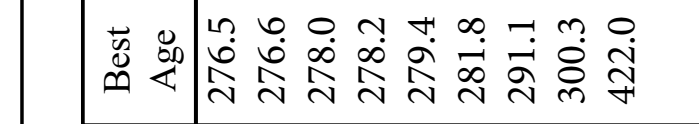 & 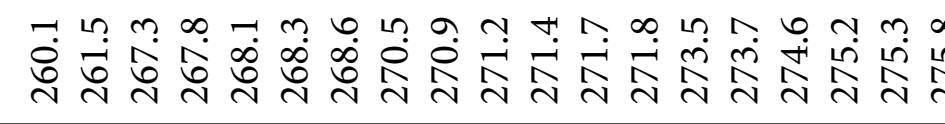 \\
\hline +1 & 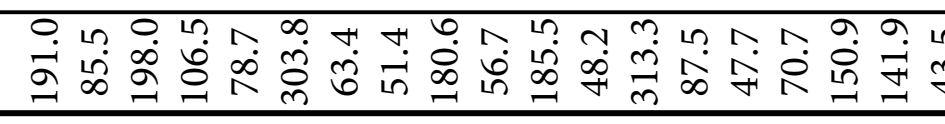 \\
\hline 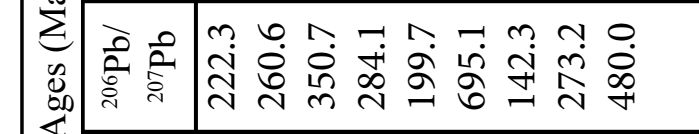 & 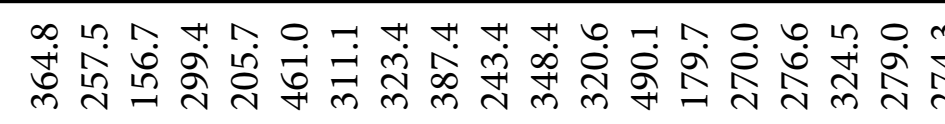 \\
\hline 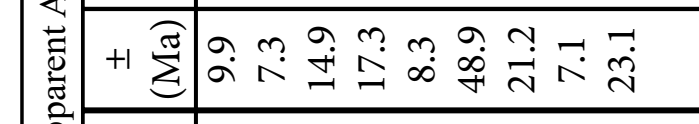 & 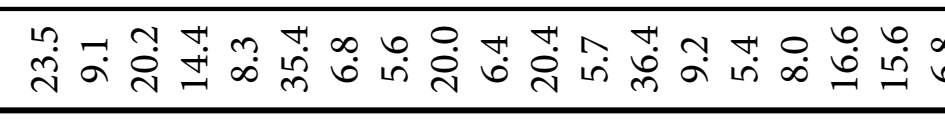 \\
\hline 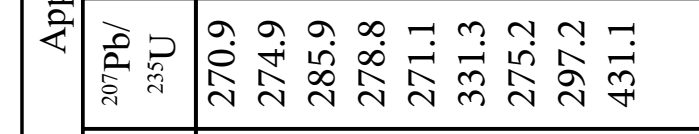 & 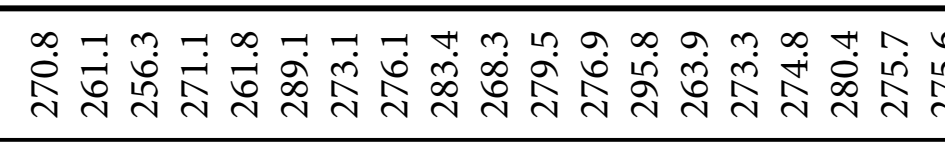 \\
\hline 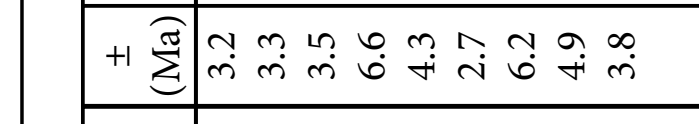 & 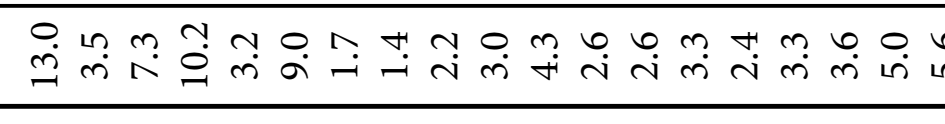 \\
\hline 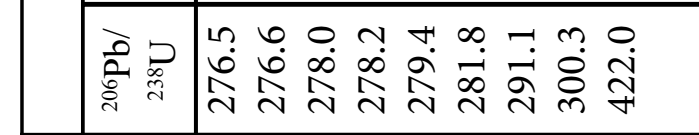 & 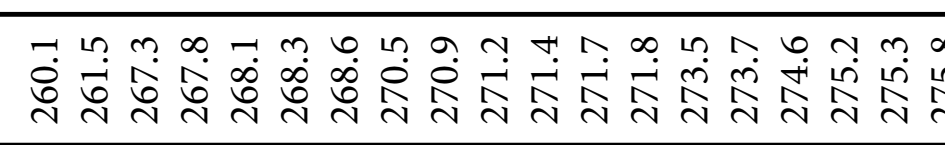 \\
\hline 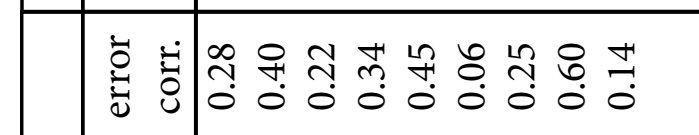 & 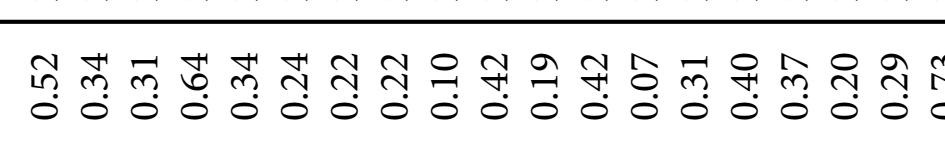 \\
\hline 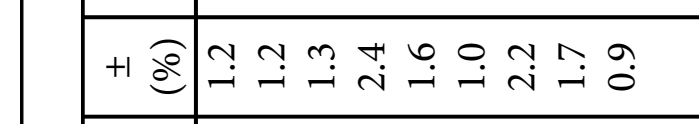 & 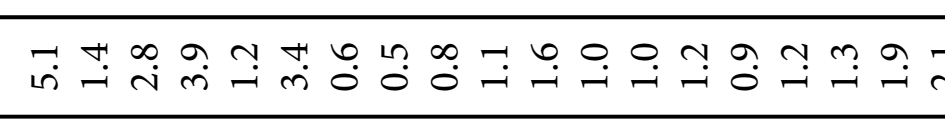 \\
\hline 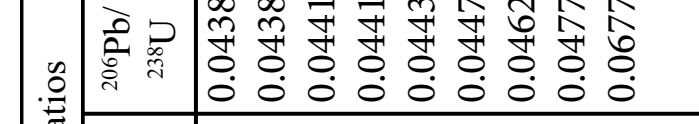 & 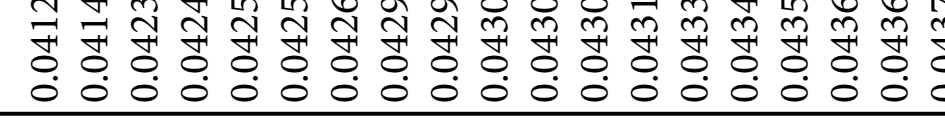 \\
\hline 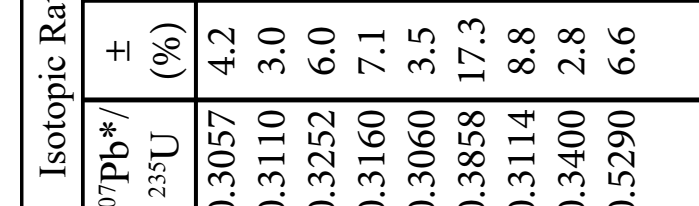 & 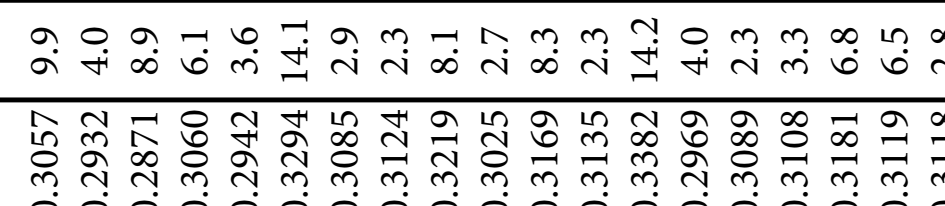 \\
\hline & 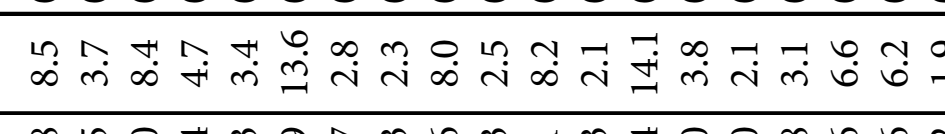 \\
\hline 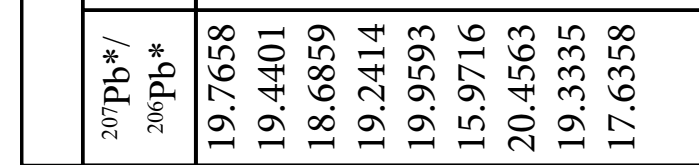 & 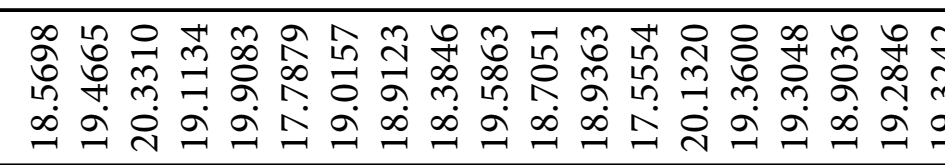 \\
\hline 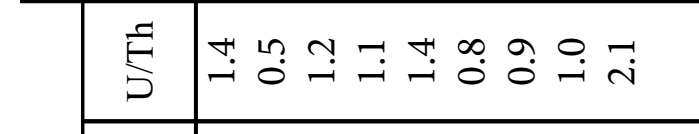 & 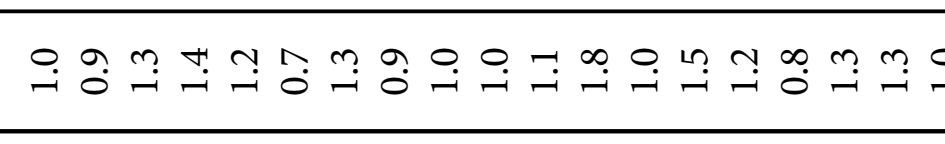 \\
\hline 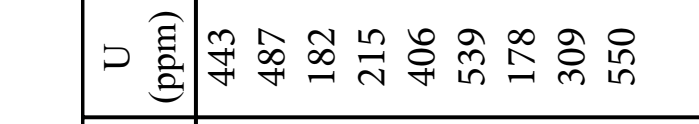 & 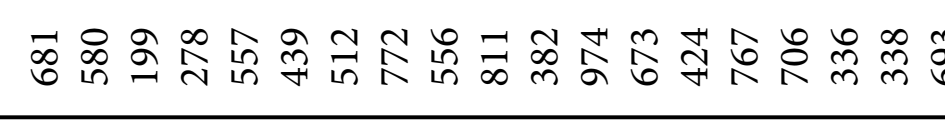 \\
\hline & \\
\hline
\end{tabular}




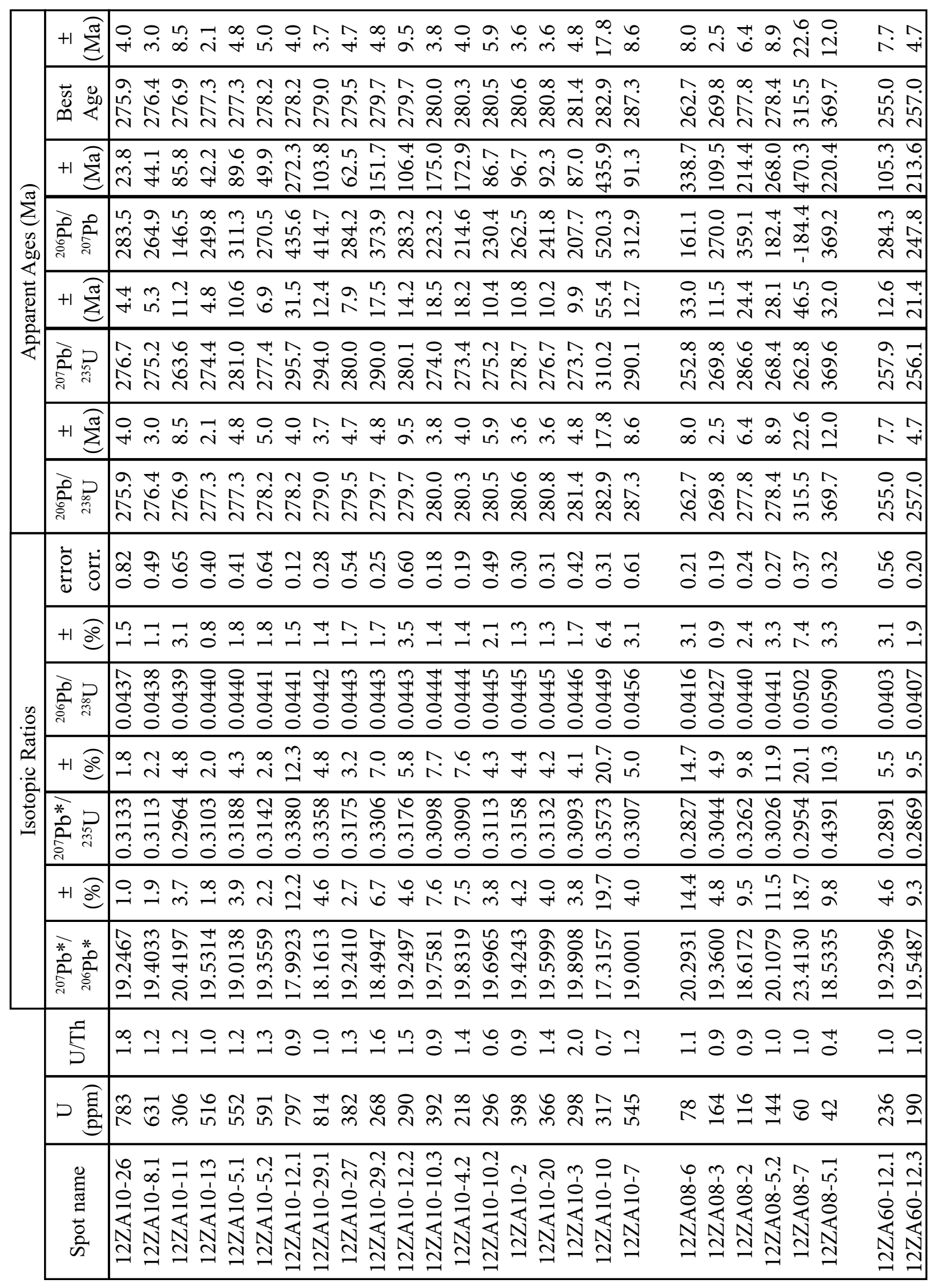




\begin{tabular}{|c|c|c|}
\hline \multirow{8}{*}{ 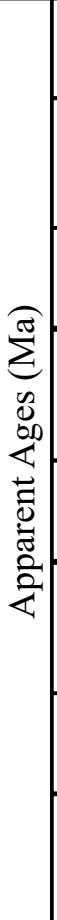 } & $+1 \sum$ & 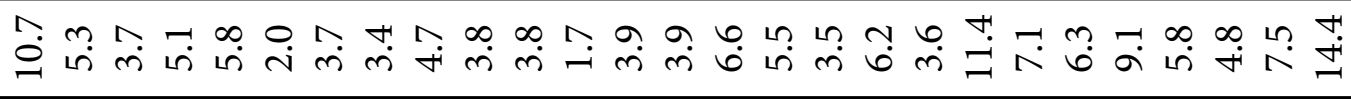 \\
\hline & 苍兽 & 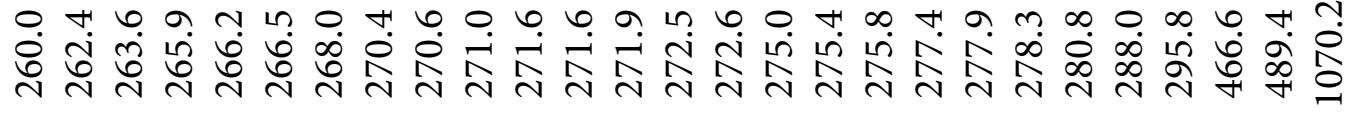 \\
\hline & 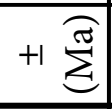 & 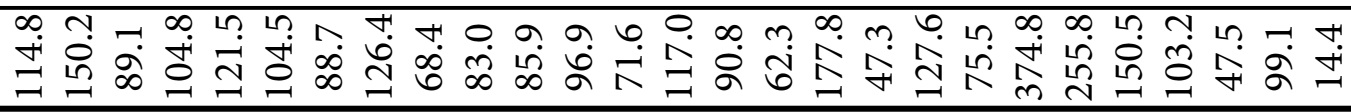 \\
\hline & के & 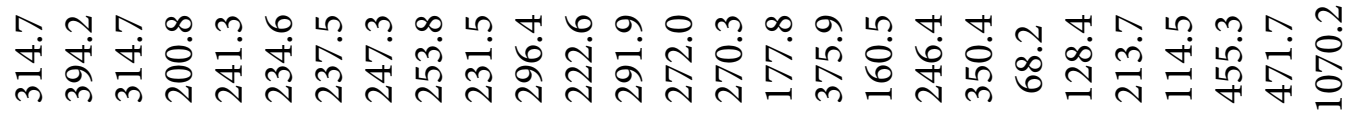 \\
\hline & $+1 \sum^{\overparen{O}}$ & 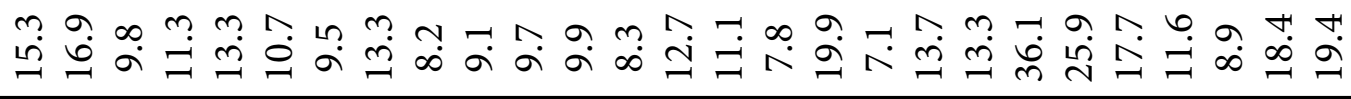 \\
\hline & Dे & 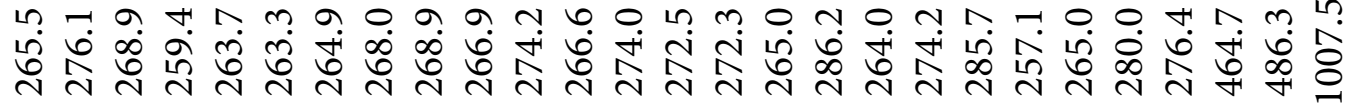 \\
\hline & 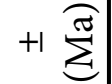 & 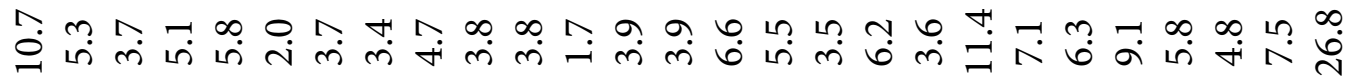 \\
\hline & के & 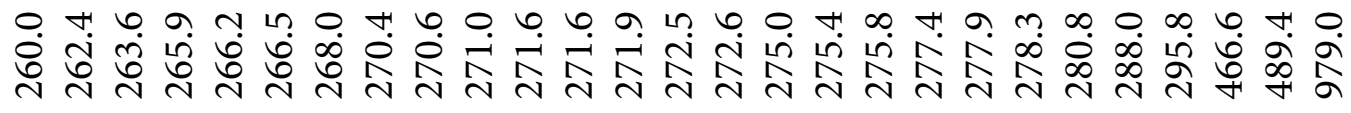 \\
\hline \multirow{10}{*}{ 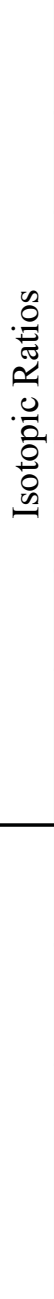 } & 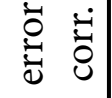 & 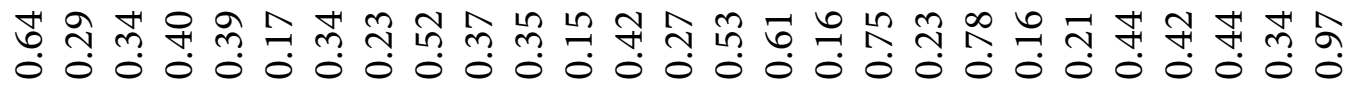 \\
\hline & $+1 \precsim$ & 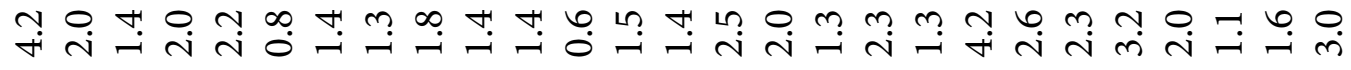 \\
\hline & की & 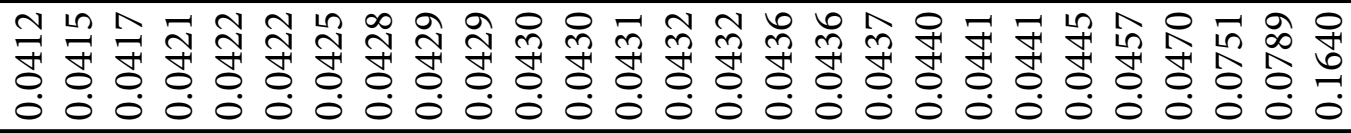 \\
\hline & $+1 \precsim$ & 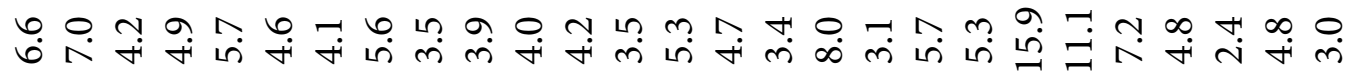 \\
\hline & 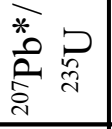 & 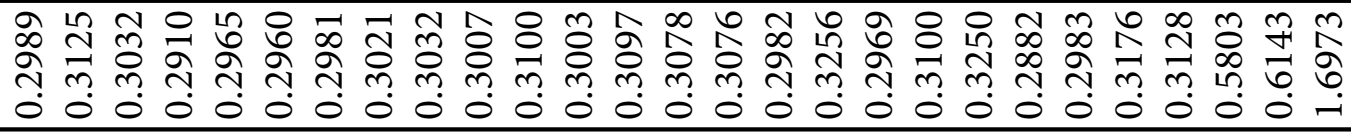 \\
\hline & $+1 \lesssim$ & 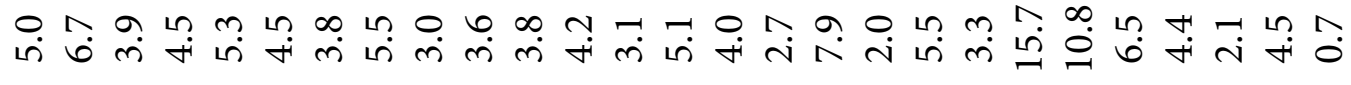 \\
\hline & 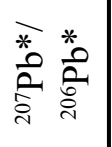 & 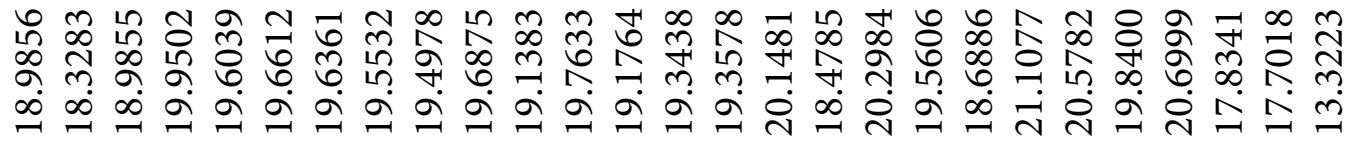 \\
\hline & $\stackrel{5}{E}$ & 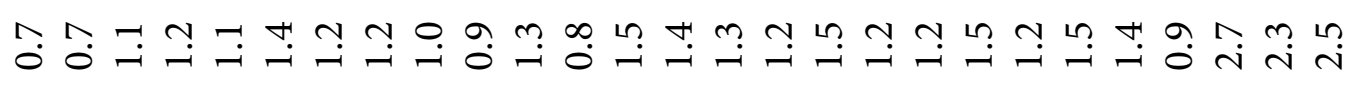 \\
\hline & $\triangleright \bar{\Xi}$ & 윳 \\
\hline & 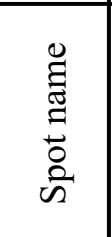 & 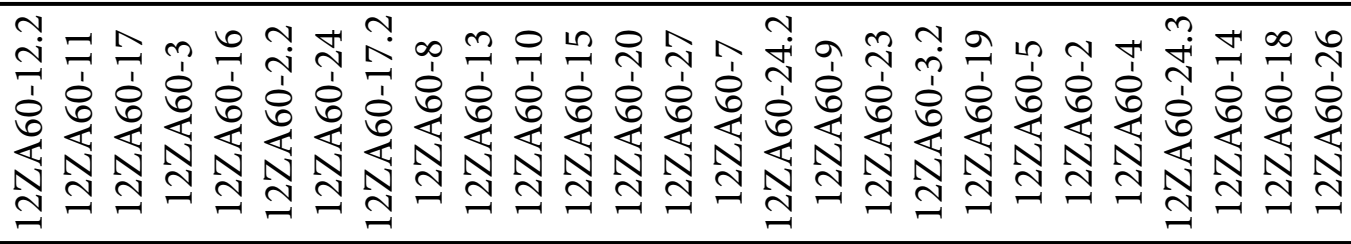 \\
\hline
\end{tabular}

